\title{
Leksičke značajke deseteračkih dvostiha u tiskanim zapisima Slavka Jankovića i rukopisnoj ostavštini Luke Lukića
}

\section{Želinski, Ana Tereza}

Doctoral thesis / Disertacija

2021

Degree Grantor / Ustanova koja je dodijelila akademski / stručni stupanj: University of Zagreb, Faculty of Humanities and Social Sciences / Sveučilište u Zagrebu, Filozofski fakultet

https://doi.org/10.17234/diss.2021.7721

Permanent link / Trajna poveznica: https://urn.nsk.hr/urn:nbn:hr:131:567024

Rights / Prava: In copyright/Zaštićeno autorskim pravom.

Download date / Datum preuzimanja: 2023-04-26

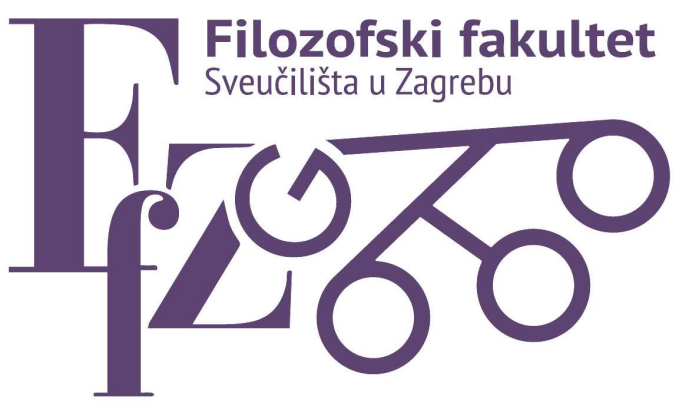

Repository / Repozitorij:

ODRAZ - open repository of the University of Zagreb

Faculty of Humanities and Social Sciences
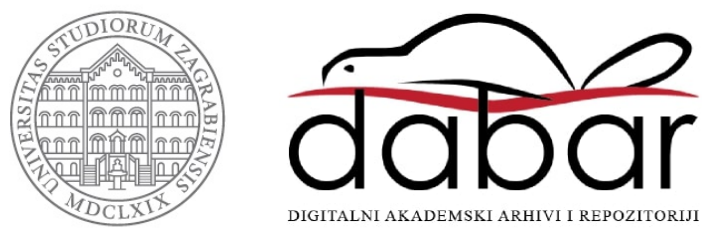


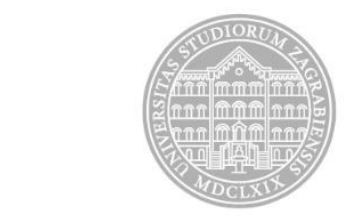

Sveučilište u Zagrebu

Filozofski fakultet

Ana Tereza Želinski

\title{
LEKSIČKE ZNAČAJKE DESETERAČKIH DVOSTIHA U TISKANIM ZAPISIMA SLAVKA JANKOVIĆA I RUKOPISNOJ OSTAVŠTINI LUKE LUKIĆA
} DOKTORSKI RAD

\author{
Mentorica: \\ prof. dr. sc. Bernardina Petrović
}

Zagreb, 2021. 


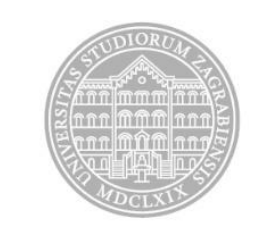

University of Zagreb

Faculty of Humanities and Social Science

Ana Tereza Želinski

\title{
LEXICAL FEATURES OF \\ DECASYLLABIC COUPLETS IN PRINTED WORKS OF SLAVKO JANKOVIĆ AND MANUSCRIPTS OF LUKA LUKIĆ
}

\author{
Doctoral dissertation \\ Supervisor: \\ Prof. Bernardina Petrović, PhD
}

Zagreb, 2021. 


\section{BIOGRAFIJA MENTORICE}

Prof. dr. sc. Bernardina Petrović rođena je 24. prosinca 1965. u Vinkovcima. Studij kroatistike završila je 1991., magistrirala je 1999., a doktorirala 2003. U istraživačko je zvanje asistentice izabrana 1999., u zvanje više asistentice 2003., u znanstveno-nastavno zvanje docentice 2004., izvanredne profesorice 2010., a redovite profesorice 2016.

Od 1991. do 1993. radila je kao profesorica hrvatskoga jezika i književnosti u osnovnoj i srednjoj školi. Od 1993. do 2004. zaposlena je u Zavodu za lingvistička istraživanja HAZU, a od 2004. na Katedri za hrvatski standardni jezik Odsjeka za kroatistiku Filozofskoga fakulteta Sveučilišta u Zagrebu. Na preddiplomskome i diplomskome studiju kroatistike Filozofskoga fakulteta Sveučilišta u Zagrebu predaje obvezne i izborne kolegije (Hrvatski standardni jezikfonologija i morfonologija, Hrvatski jezik za nastavnike, Hrvatska leksikologija, Normativne razine hrvatskoga standardnog jezika, Tekstna lingvistika. U akademskoj godini 2006./2007. predavala je kolegij Hrvatski standardni jezik na Učiteljskome fakultetu Sveučilišta u Zagrebu. U akademskoj godini 2007./2008. gostujućom je profesoricom u okviru CEEPUS-ove stipendije na Institutu za slavistiku Sveučilišta u Grazu. Od akademske godine 2008./2009. nositeljicom je i s dr. sc. Milicom Mihaljević izvoditeljicom izbornoga kolegija Hrvatski jezik u inženjerskoj praksi na Fakultetu elektrotehnike i računarstva Sveučilišta u Zagrebu.

Objavila je četiri knjige, osamdesetak radova u znanstvenim časopisima i zbornicima radova sa znanstvenih skupova te sudjelovala izlaganjima na osamdesetak međunarodnih i domaćih znanstvenih skupova. Bila je tajnica uredništva Filologije (od 1999. do 2004.) i predsjednica Državnoga povjerenstva u Natjecanju u poznavanju hrvatskoga jezika (od 2012. do 2017.). Članica je uredništva znanstvenoga časopisa Croatica (od 2016.) i glavna urednica velikogoričkoga časopisa Luč (od 2013.). Aktivno je sudjelovala u organizaciji nekoliko znanstvenih skupova i kongresa te u uređivanju znanstvenih i stručnih publikacija. Održala je sedamdesetak pozvanih predavanja na stručnim skupovima i seminarima, ljetnim školama i znanstvenopopularnim tribinama. U ak. god. 2014./2015. i 2015./2016. bila je pročelnica Odsjeka za kroatistiku. Članica je Hrvatskoga filološkog društva. Bila je potpredsjednica Ogranka Matice hrvatske u Velikoj Gorici (2008. - 2018.).

Bibliografija https://www.bib.irb.hr/pregled/znanstvenici/232081 


\section{ZAHVALE}

Nijedno djelo, zapis, misao i riječ nije plod samo autora. Pomoć u traganju, pri izradi i konačnome oblikovanju ove disertacije mogu zahvaliti brojnim osobama koji su svojim svesrdnim pristupom, pomnom strpljivošću i susretljivošću te konstruktivnim komentarima pomogli da ova disertacija ugleda svjetlo dana. Zahvaljujem akademiku Stjepanu Damjanoviću, profesoru emeritusu čiji je primjerak Jankovićeve zbirke pismica i razgovor na ispitu potaknuo lavinu razmišljanja o analizi deseteračkih dvostiha, etnomuzikologu Mihaelu Feriću, poznavatelju slavonske tradicijske glazbe, čije je nastojanje i sveukupni doprinos pri opsežnom i zahtjevnom poslu pripreme uvrštavanja bećarca na listu zaštićenih dobara Republike Hrvatske i UNESCO-a samo učvrstilo želju za detaljnijim opisom tog nematerijalnog kulturnog dobra, Karolini Lukač, višoj kustosici Etnografskog odjela čiji entuzijazam pri sređivanju Lukićeve rukopisne ostavštine nadilazi svaki ljudski napor, Marku Lukinu, stručnom suradniku na Institutu za etnologiju i folkloristiku čije strpljenje i srdačnost zaslužuje svaku pohvalu.

Bez dugogodišnjeg, iscrpnog, detaljnog i vrlo bogatog zapisivačkog i prikupljačkog posla Luke Lukića te sistematiziranih triju zbirki šokačkih distiha, tzv. pismica Slavka Jankovića, oblikovanje, sređivanje i konačni izgled disertacije, dakako bio bi nemoguć.

Veliko hvala i mentorici prof. dr. sc. Bernardini Petrović koja je svojim detaljnim analiziranjem, konstruktivnim komentarima i korisnim opaskama s bezgranično mnogo strpljenja pridonijela kvaliteti disertacije. Posebna joj zahvala na poticanju za istraživanjem rukopisne ostavštine Luke Lukića čiji je rezultat stvorio nova vlastita gledišta na etnomuzikološki rad i etnomuzikologe. Bez njezina istančana osjećaja za istraživanjem građe, dobronamjernih savjeta i pravovaljanih uputa Lukićeva ostavština ostala bi u sjeni neistražene nematerijalne kulturne baštine, a time i djelomično zakinuta sveobuhvatnom analizom. Hvala za iskrenost, susretljivost i nesebičnost.

Hvala i svima onima koji su komentarima, ophođenjem i razumijevanjem neznajući pomagali, poticali, usmjeravali, činili sve da me zadrže na putu bez povratka, na putu prema konačnom cilju ...

I roditeljima Ivanki i Ivici, braći Josipu i Antunu, suprugu Mariju i kćeri Heleni ... 


\section{SAŽETAK}

Deseterački dvostisi Slavka Jankovića i Luke Lukića vjerodostojni su prikaz života, kulture i običaja na području Slavonije, Baranje i Srijema do sredine 20. stoljeća. Ta vrijedna ostavština s oko 8.000 dvostiha pruža relevantan uvid u leksik toga vremena te pokazuje zastupljenost stranojezičnih elemenata i njegov utjecaj na autohtoni leksički sloj. U disertaciji se istražuju leksičke značajke dvostiha iz prikupljenoga korpusa s osobitim obzirom na polisemičnost, homonimičnost i sinonimičnost te propituje utjecaj posuđenica iz njemačkoga i turskoga jezika na sadržaj i strukturu dvostiha. Posebna je pozornost usmjerena problematici međujezičnih dodira, jezičnom posuđivanju, prilagodbi posuđenica na fonološkoj i morfološkoj, a poglavito na semantičkoj i leksičkoj razini. Prikupljeni korpus čine Jankovićevi tiskani zapisi dvostiha te neistražena i jezično neopisana rukopisna ostavština Luke Lukića čineći tako iznimno bogatstvo gotovo zaboravljenoga pučkog govora Brodskoga Posavlja.

Ključne riječi: Slavko Janković, Luka Lukić, pismice, sinonimičnost, homonimičnost, polisemičnost, jezični dodiri, turcizmi, germanizmi 


\section{EXTENDED SUMMARY}

Decasyllabic couplets by Slavko Janković and Luka Lukić are an authentic portrait of life, culture and customs in Slavonija, Baranja and Srijem up to the middle of the $20^{\text {th }}$ century. This valuable legacy, which includes around 8,000 couplets, offers a relevant insight into the lexicon of that time and shows the representation of foreign language elements and its effect on the indigenous lexical layer.

This dissertation will explore the lexical significance of couplets from the collected corpus with regards to polysemy, homonymy and synonymy, and examine the influence of loan-words from German and Turkish languages on the contents and structure of the couplet. Special attention will be given to the issue of interlingual contacts, linguistic borrowing, adaptation of loan-words on a phonological, morphological, semantic and lexical level. The collected corpus is comprised of Janković's printed couples and the unexplored and linguistically undescribed handwritten legacy of Luka Lukić, which form the unique treasure of the almost forgotten folk discourse of Brodsko Posavlje.

Therefore, the aim of this dissertation is an exhaustive overview, description and analysis of the influence of Turkish and German loan-words on the formation of decasyllabic couplets in Slavonija, Baranja and Srijem, with special consideration of the semantic potential of lexemes, and regards to homonymy, synonymy and polysemy in the collected corpus. Likewise, the aim of the dissertation was to use comparative analysis to contrast the writings of the two authors and to describe particular orthographical, grammatical, i.e. phonological, morphological, word-formational, syntactical and lexical features.

The first hypothesis argues that the comparison of the two corpora up to the middle of the $20^{\text {th }}$ century shows that polysemy is more widespread than homonymy, and homonymy that synonymy. The second hypothesis argues that Turkish loan-words are more widespread than German loan-words in decasyllabic couplets, from culinary lexicon to clothes and house inventory, botany and gardening and many other agricultural sectors and crafts, and insults, nicknames and characteristics, human relations and emotions.

The hypotheses of this dissertation will be tested on the collected corpus comprised of 8,000 couplets from the works of Slavko Janković, one of the most famous Croatian ethnomusicologists of his time, and of the manuscripts of Luka Lukić, the most significant ethnographer, melographer and folklore researcher in Slavonija from the end of the $19^{\text {th }}$ century until the middle of the $20^{\text {th }}$ century (Blaževac-Pajkov 2016). This two corpora are differently 
formed. While Janković's writings are printed in three song-books (Janković 1967, 1970, 1974) and are easily accesible, Lukić's couplets are a part of a manuscript legacy which is kept in The Museum of Brodsko Posavlje at the Etnographic Department in Slavonski Brod. Janković's and Lukić's decasyllabic couplets have not yet been the subject of linguistic study and assessment, therefore detailed analysis, verification and evaluation is needed.

The dissertation explores lexical and semantic relationships of lexemes with a particular overview of synonymy, homonymy and polysemy, analyses and determines the cultural and historic framework of languages in contact, the relationships between domestic and loan-words, their absorption and adaptation on a phonological, morphological, semantic and lexical level, and ascertains the level of influence of loan-words on the language of decasyllabic couplets and the semantic areas where they are documented. Through the studied manuscript legacy of Luka Lukić and printed writings of Slavko Janković, the dissertation also implements an analysis of orthography and grammar of traditional discourses and describes particular orthographical, grammar, i.e. phonological, morphological, word-formational, syntactical and lexical features. The couplets are formed spontaneously "alongside life occasions: rituals and customs, work, leisure, jest and momentary elations, weddings, births and deaths..." (Botica 1995), that is, in every circumstance and situation that were a part of everyday traditional life of a Šokac. Since the nature of the couplet is characterized both by being documented and being informative, which therefore provides the ability to reconstruct objective facts, place and date of the action, certain information about history, historic events (Barišić 2016a), politics and political situation, the economy, current economic situation and existing societal issues, it is expected that we find a presence of loan-words in the various lexicon which primarily refers to culinary domain, clothes, decorations, jewelry and textiles, house inventory, garden, botany, agriculture, crafts, military, but also names, human relations and emotions.

The initial phase of the research will explore in detail the recent foreign and domestic literature which primarily studies linguistical contacts and complexities of lexical-semantic relationships. Subsequently, from the collected database, which is comprised of printed writings of Slavko Janković and the manuscript legacy of Luka Lukić, a corpus of decasyllabic couplets will be formed. The corpus, comprised of "these small couplets, which melt all the original local, all the lines of force that form local identification" (Botica 2013), will become the backbone of the database study from a linguistic point of view. The dissertation also brings a detailed description and analysis of up to this time unexplored manuscript legacy of couplets of Luka Lukić. 
The central part of the research will be dedicated to the corpus analysis. Comparative method will be primarily used to describe decasyllabic couplets, and the above-mentioned hypotheses will be verified by an inductive-deductive method. First, the theoretical starting points will be determined and decasyllabic couplets defined, and lexical-semantic relationships with a special overview of synonymy, homonymy and polysemy within the collected corpus will be analyzed. Preliminary research indicates that there are not many synonymous and homonymous lexemes in the body of decasyllabic couplets, while the polysemous lexemes are abundantly represented, and there is large number of those that are not registered in Croatian lexicographic handbooks. An important part of the work will include the linguistics of language contacts as per theoretical points of reference of Croatian contactological literature. Next, the history of Croatian-Ottoman and Croatian-German linguistic contacts will be explored, linguistic borrowing analyzed, its causes, the adaptation of loan-words and their influence on the lexicon of decasyllabic couplets.

Finally, main insights and the verification of hypotheses will be synthesized, and considering the unexplored segments of the corpus within the stated areas of lexicology, documentation of lexemes that can be used for supplementation of dictionary description of the Croatian language can be anticipated.

Decasyllabic couplets as a kind of lyrical form are most common in Slavonija, Baranja and Srijem and are "an indicator of abundance of Croatian folk treasure" (Botica 1996) and promotors of centuries-long tradition and culture. Because they "have a specific melodic, morphologic, syntactic and semantic recognizability" (Botica 2013) they require a unique approach of particular sciences.

While, from an ethnomusicological standpoint, decasyllabic couplets have been described in detail, and there is a certain diversity of approach, subjects of research and scientific engagement with couplets, from a literary theory standpoint, decasyllabic couplets are mostly limited to bećarac (Slavonian humorous-ribald folk song). Several monographies unify them as printed writings, the Josip Užarević monography (2012) classifies them within the literary minimalist genre, Pšihistal (2008) analyses the coding of love in the collection Šokačke pismice Slavka Jankovića, Dragić (2008) briefly defines bećarac while in his magazine article Užarević (2009) discusses the poetics of bećarac and its characteristics. Within this bibliography bećarac is determined as a rhymed decasyllabic couplet, folk vocalinstrumental minimal chant of Slavonija-Baranja-Srijem (Užarević 2009: 111). Bošković-Stulli (1978: 305) suggests that it originated in the second half of the $19^{\text {th }}$ century, and Leskovac 
(1968: 107) points out that bećarac is situated regionally (from Srijem, Banat and Bačka and Baranja to Slavonija and Šokadija to Kordun and Lika) placing it in an even broader location than it is done in this dissertation. While Botica (2013) considers short decasyllabic chants and rhymes, including bećarac, to be a special and very prolific kind of lyrical chants, according to Dragić (2008: 127) many of the bećaracs belong to folk literature and do not have an aesthetic function. That it is more than merely a folk form of having fun is demonstrated by the fact that Republic of Croatia Ministry of Culture has included it in the List of Protected Cultural Treasures in 2007, and in 2011 it was included in the UNESCO List of Intangible Cultural Heritage.

Subsequently, it is unclear why decasyllabic couplets have not been the subject-matter of linguistic interest or more detailed research. There are few references about the lexical layer of decasyllabic couplets in the recent linguistical and philological literature. It is therefore necessary to conduct the required research within lexicology.

The corpus of decasyllabic couplets in this dissertation consolidates printed writings from collections Šokačke pismice Slavka Jankovića $(1967,1970,1974)$ and the unpublished manuscript of Luka Lukić - a total of 8,000 decasyllabic couplets of bećarac, drumarac, svatovac, pokladarac and other minimalistic forms of spoken folk expression. Preliminary research confirms some similarities and differences of those sources. Lukić's manuscript is older in origin, and considering that Janković analyzed Lukić's Popijevke iz okolice Slavonskog Broda (1919), it is not surprising that his song-book repeats many of those couplets. Lukić registered couplets of Brodsko Posavlje, including Oprisavci, Varoš, Kaniža, Klakar, Ruščica and Donja Bebrina, and Janković described and collected couplets from certain places in Slavonija, Baranja and Srijem. In addition to the collected couplets, both record music notes for particular couplets. Janković termed all the couplets as pismice, that is, decasyllable couplets, while Lukić categorized them as priskočnice or chants. Literary historians accept the suggested terminology, identifying pismice with "decasyllabic couplets" (Bošković-Stulli 1978: 305). This paper accepts the term decasyllabic couplets while not limiting it exclusively to bećarac or other individual kinds, because the couplets differentiate only in the occasion for which they are written or the lyrical subject that is producing them. All forms of decasyllabic couplets are characterized by the same structure, minimalism, intermediality, rhyme, humorous context and out-singing, and therefore it cannot be justified to single out just one form. 
As the paper is focused primarily on lexical characteristics, relationships between words and loan-words within the decasyllabic couplets structure will primarily be analyzed. Decasyllabic couplets abound in the latter, as shown in preliminary research. German and Turkish loan-words comprise approximately $70 \%$ of the corpus and their analyses will constitute a majority of the paper. When defining loan-words, this paper will incline towards the term Turkish loan-words, rather than Oriental loan-words, and the statement by Hanka Glibanović-Vajzović (1986: 141) that "Turkish loan-words are all words of Oriental and other origin received through Turkish language agency, regardless of their deeper etymology". After initial research, it has been established that the area of Slavonija, Baranja and Srijem has been subjected to German and Turkish influence during its long and prolific history, which has left trace in Croatian language as well. The reasons for this can be found in long-term presence of Ottomans in the Slavonian area since the $14^{\text {th }}$ century when Croatian language came into contact with the Ottoman influence, and later when the Ottomans were forced out in the $18^{\text {th }}$ century in the establishment of the Military Border (Vojna krajina) which served as a military-police district for the defense from the Ottomans (Moačanin and Valentić 1981). It was then that one language was substituted for another, German (Žepić 1996). As a result of age-long historical events and political changes, German loan-words have, because of certain cultural, political and other reasons, become a language necessity among the members of immigrant German people and the native population. Their usage improved mutual understanding, but also the need to vocally express new elements of extra-linguistic reality which were introduced by interlocking the two cultures (Kordić 2006).

Considering these facts, German and Turkish loan-words will be analyzed on a phonological, morphological, semantic and lexical level, using primarily the principles of contact linguistics (Filipović 1979, Filipović 1986, Dabo-Denegri 1998, Sočanac 2004, Stojić 2008). In order to make the analysis more complete, phonological and morphological systems of contact languages will be compared and it will be determined how a loan-word, when being integrated in the receiving language system, shaped its meanings, and how those meanings relate to the meanings in the model of the donor language, the changes that occurred in the adaptation process and why those changes occurred. The best way to detect the effect of language contacts of two languages and to determine which part of the lexicon was significantly influenced by loan-words is by analyzing the lexical level of language structure (Barišić 2016b).

The dissertation will research in detail the lexical-semantic relationships of lexemes with special regards to synonymy, homonymy and polysemy. As opposed to synonymy 
(Melvinger 1984, Petrović 2005) and polysemy (Raffaelli 2015, Tafra 2017) for which there is extensive recent literature, the phenomenon of homonymy (Samardžija 1989, Dobričević 2000, Tafra 2016) has not yet received adequate attention within the Croatian language, and therefore polysemy has not even been unambiguously defined (Hudeček, Mihaljević 2009), which leaves enough space to more thoroughly and systematically analyze homonymy in this dissertation. The paper is expected to note new meanings conditioned by existing decasyllabic couplets which could complete the lexical database and thereby contribute to the semantic description of lexemes in the lexicographic descriptions of the Croatian language.

Keywords: Slavko Janković, Luka Lukić, decasyllabic couplets, synonymy, homonymy, polisemy, interlinguistic influence, Germanisms, Turkish loanwords 


\section{SADRŽAJ}

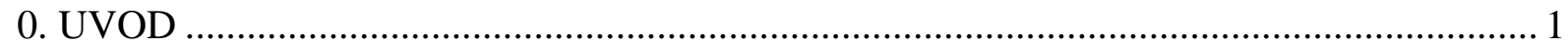

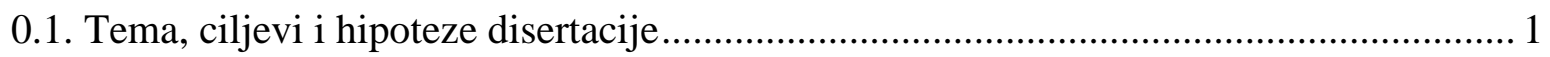

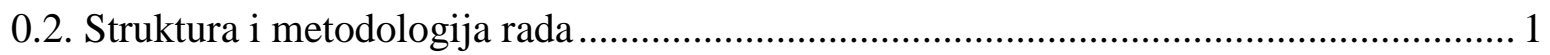

0.3. Pregled dosadašnjih znanstvenih spoznaja $i$ istraživanja .......................................... 3

1. RUKOPISNA OSTAVŠTINA LUKE LUKIĆA ….................................................... 7

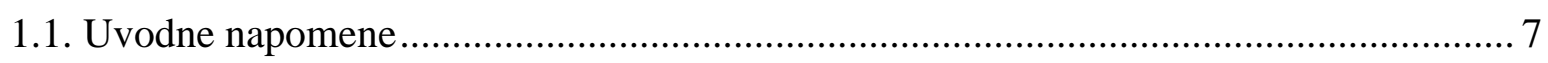

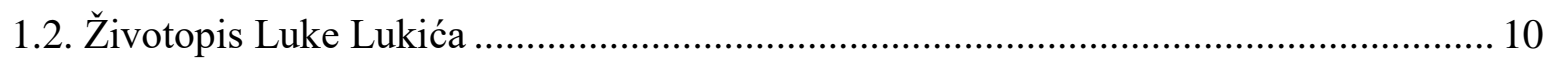

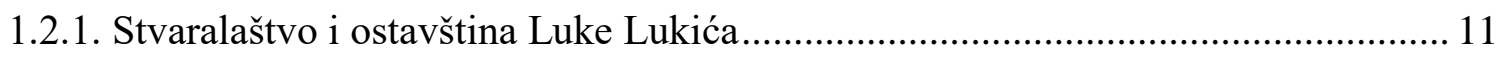

1.2.1.1. Lukićeve rukopisne zbirke pjesama ............................................................. 14

1.2.1.2. Dvostihovi iz Slavonije - priskočnice......................................................... 15

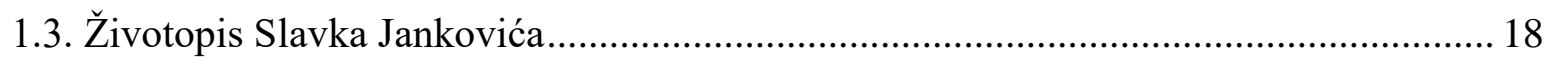

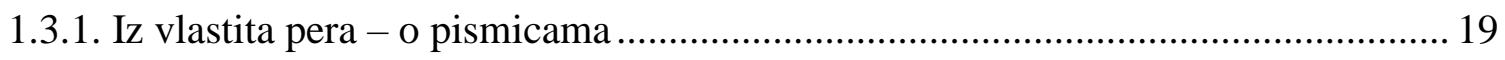

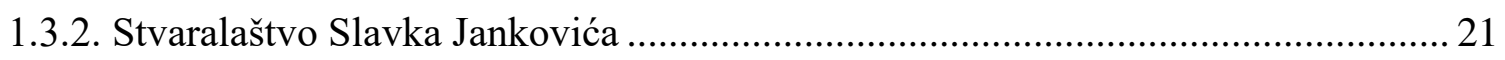

1.3.3. Doprinosi i zasluge Slavka Jankovića ............................................................... 23

1.4. Pravopisne i gramatičke značajke Lukićevih rukopisa i Jankovićevih zbirki.............. 25

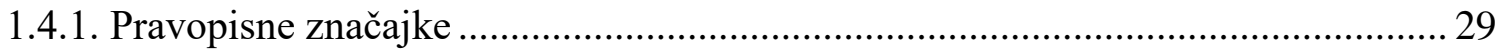

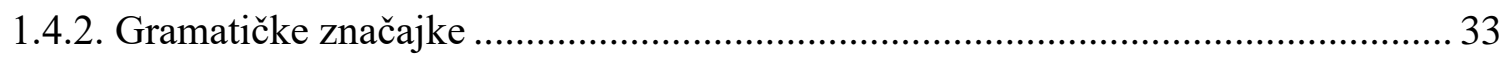

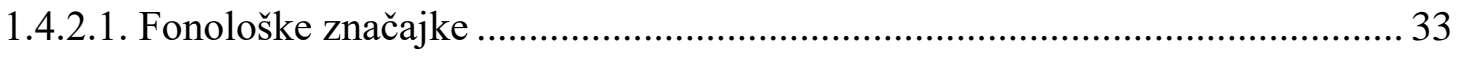

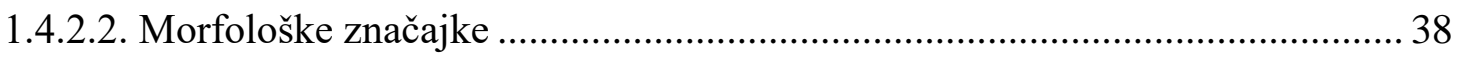

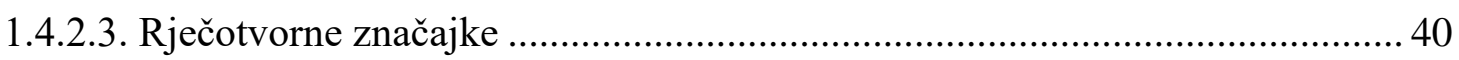

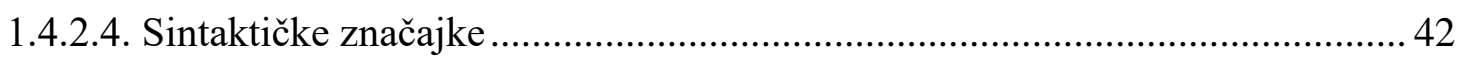

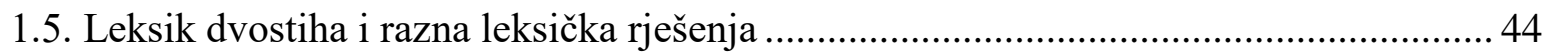

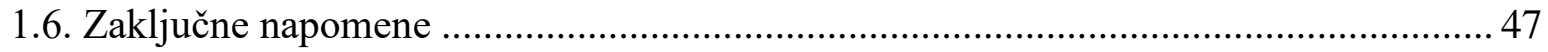

2. LEKSIČKO-SEMANTIČKI ODNOSI U DVOSTISIMA ........................................... 50

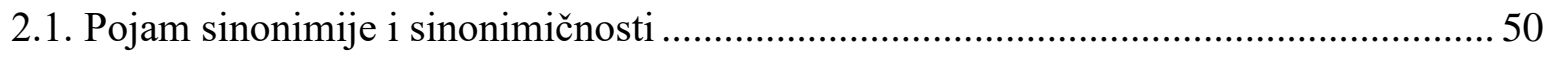

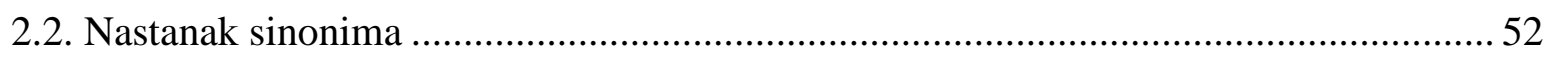

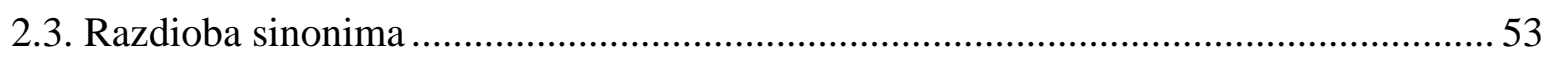

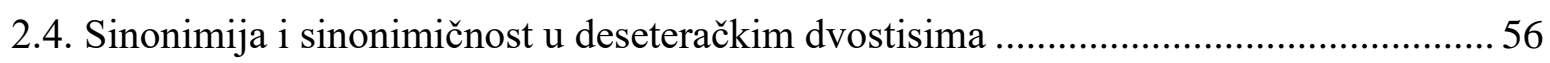

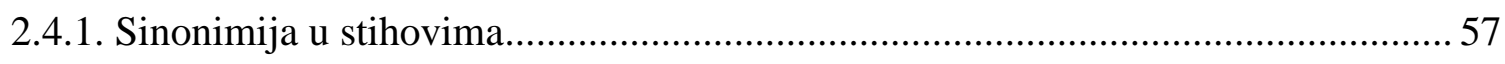

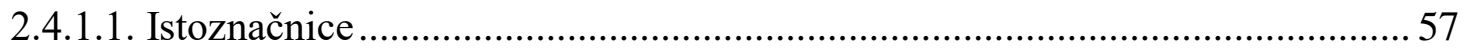

2.4.1.1.1. Istoznačnice u Jankovićevim zbirkama i Lukićevim zapisima ................ 58

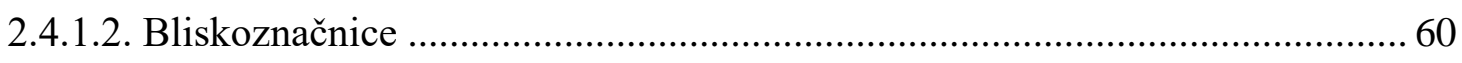

2.4.1.2.1. Bliskoznačnice u Jankovićevim zbirkama i Lukićevim zapisima............ 61

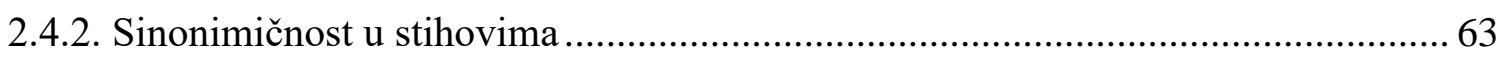




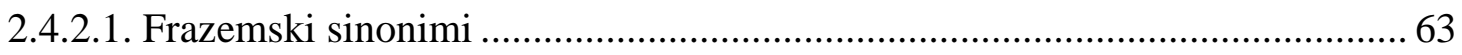

2.4.2.1.1. Frazemski sinonimi u Jankovićevim zbirkama i Lukićevim zapisima ........ 64

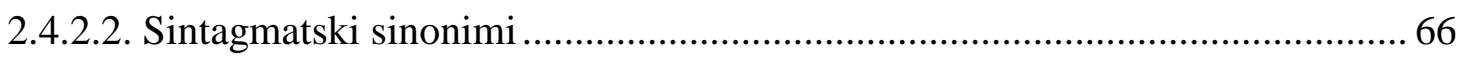

2.4.2.2.1. Sintagmatski sinonimi u Jankovićevim zbirkama i Lukićevim zapisima 66

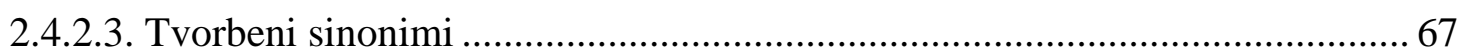

2.4.2.3.1. Tvorbeni sinonimi u Jankovićevim zbirkama i Lukićevim zapisima ...... 67

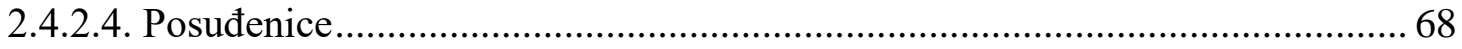

2.4.2.4.1. Posuđenice u Jankovićevim zbirkama i Lukićevim zapisima .................. 69

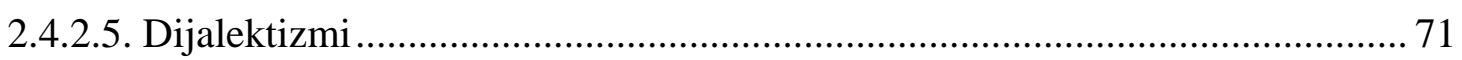

2.4.2.5.1. Dijalektizmi u Jankovićevim zbirkama i Lukićevim zapisima ............... 71

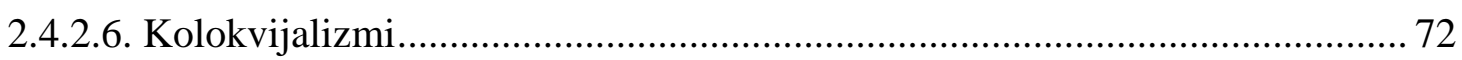

2.4.2.6.1. Kolokvijalizmi u Jankovićevim zbirkama i Lukićevim zapisima............ 72

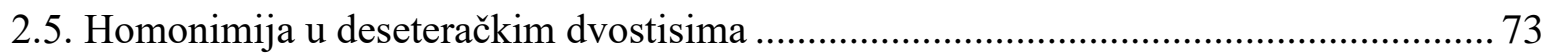

2.5.1. Homonimijska pojmovna i terminološka previranja ........................................... 73

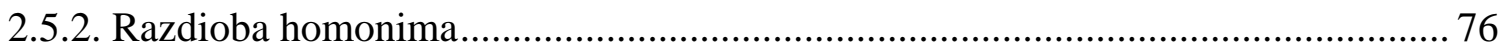

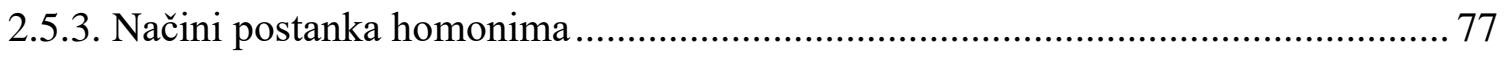

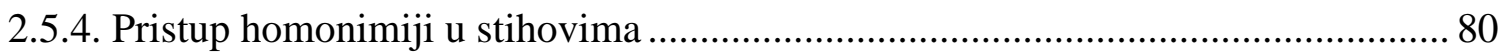

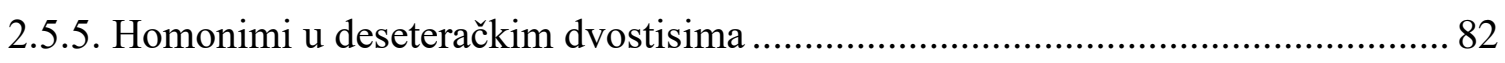

2.5.6. Oblični homonimi (homoforme) u deseteračkim dvostisima................................ 83

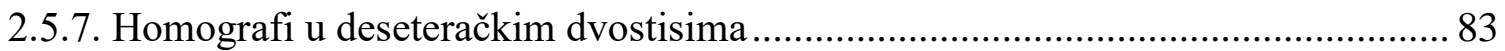

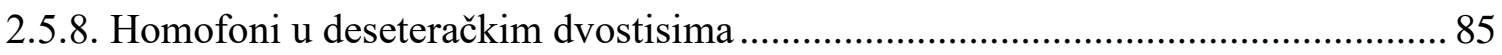

2.5.9. Ovjerenost leksema kao homonima, homoformi, homografa i homofona.............. 85

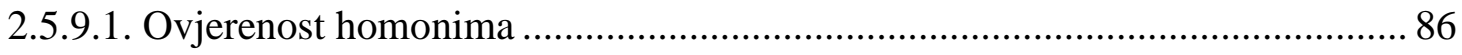

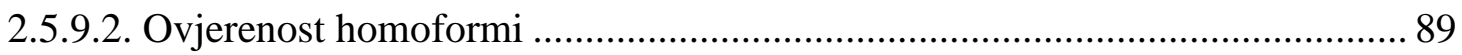

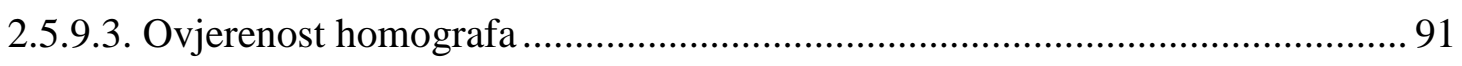

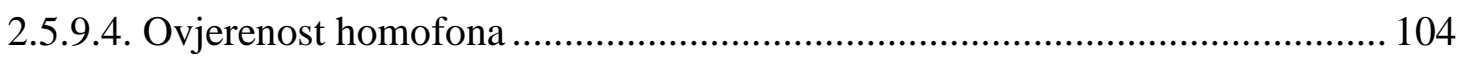

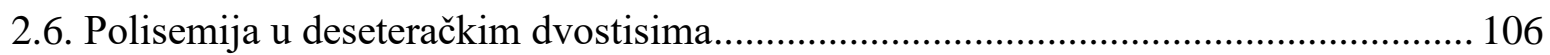

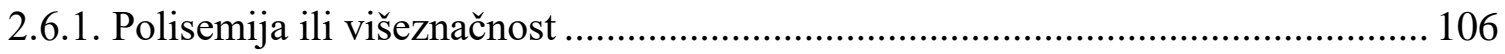

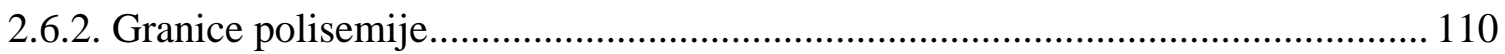

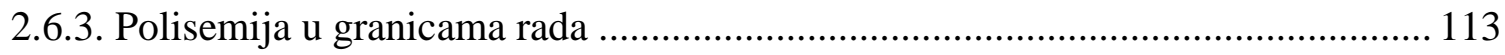

2.6.3.1. Analiza polisemnih leksema deseteračkih dvostiha ..................................... 114

3. PRILAGODBA GERMANIZAMA I TURCIZAMA I NJIHOV UTJECAJ NA JEZIK

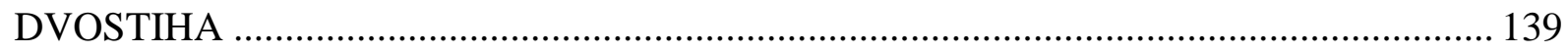

3.1. Društveno-povijesni kontekst hrvatsko-osmansko-njemačkih dodira ....................... 140

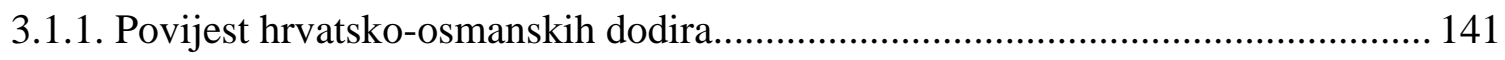

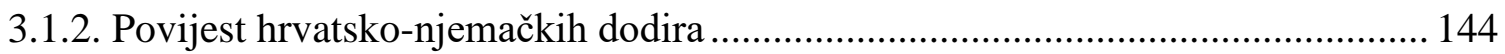

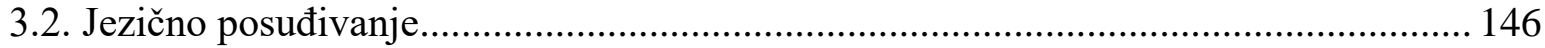




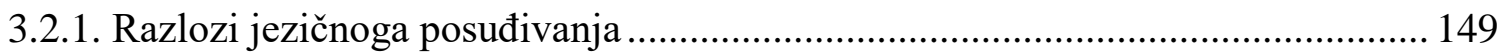

3.2.2. Posredno i neposredno posuđivanje ............................................................... 150

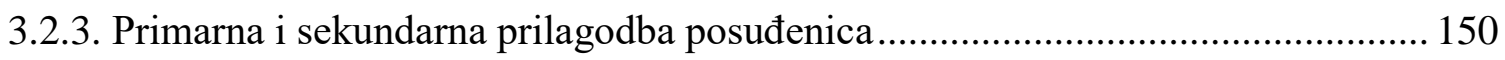

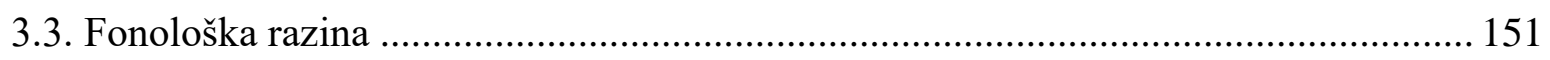

3.3.1. Usporedba fonoloških sustava turskoga, njemačkoga i hrvatskoga jezika .......... 153

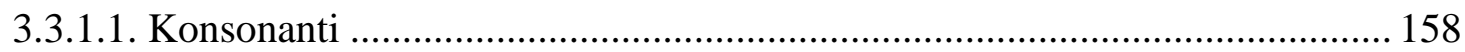

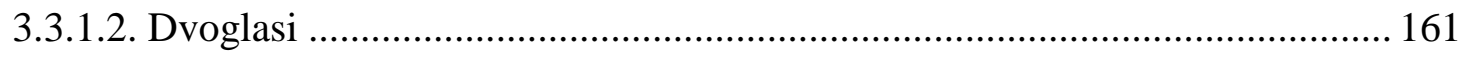

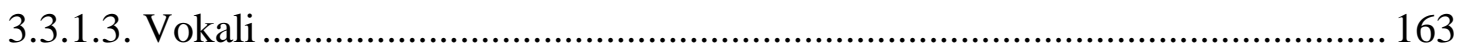

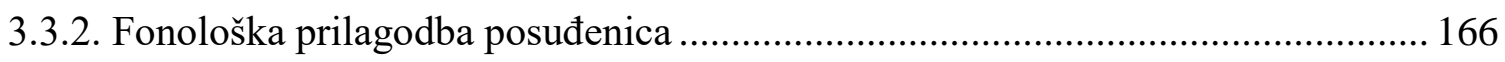

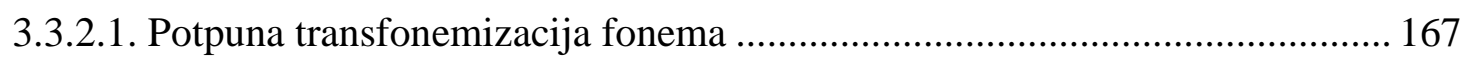

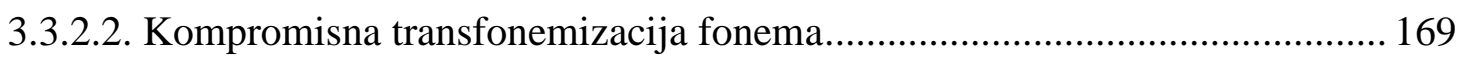

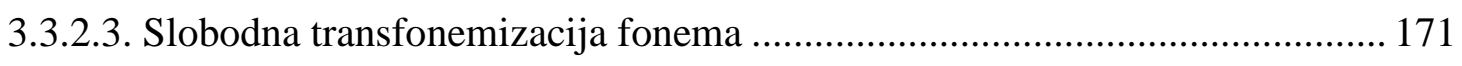

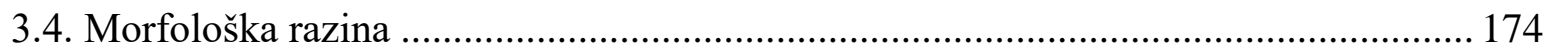

3.4.1. Usporedba morfoloških sustava turskoga, njemačkoga i hrvatskoga jezika ........ 174

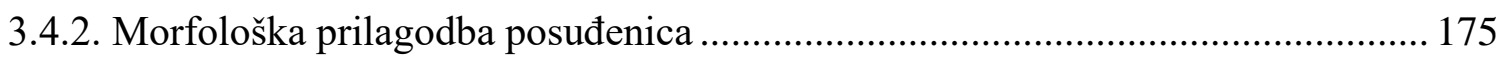

3.4.2.1. Nulta transmorfemizacija morfema......................................................... 175

3.4.2.2. Kompromisna transmorfemizacija morfema.......................................... 177

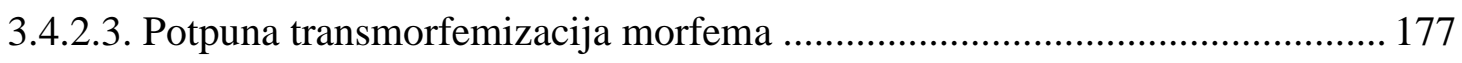

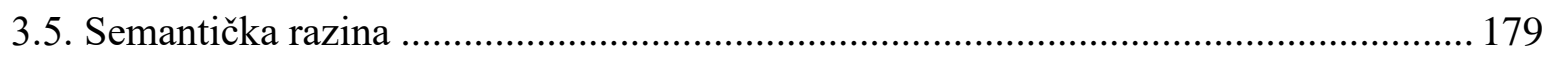

3.5.1. Semantičke promjene i njezini uzroci, priroda i posljedice na značenje posuđenica

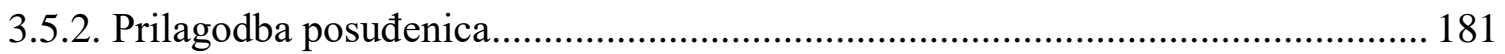

3.5.2.1. Primarna prilagodba posuđenica ................................................................ 182

3.5.2.1.1. Nulta semantička ekstenzija ........................................................... 182

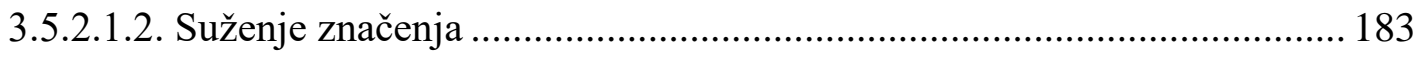

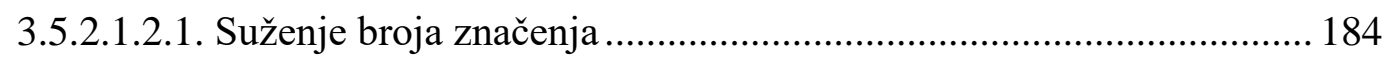

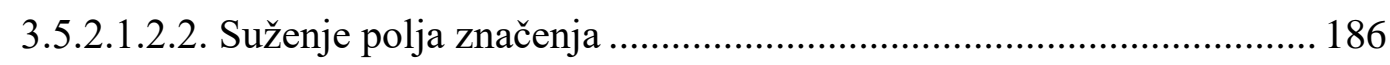

3.5.2.2. Sekundarna prilagodba posuđenica ......................................................... 187

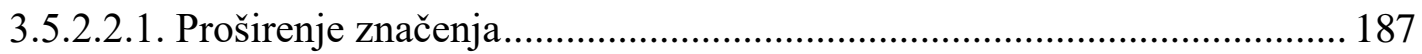

3.5.2.2.1.1. Proširenje polja značenja ................................................................. 188

3.5.2.2.1.2. Proširenje broja značenja ........................................................ 189

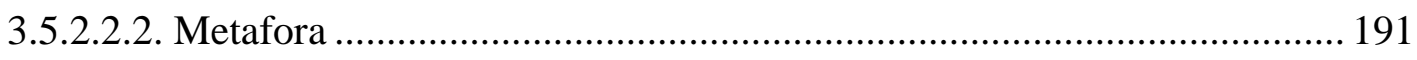

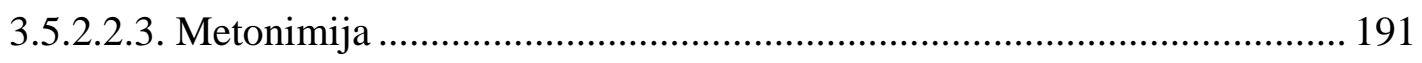

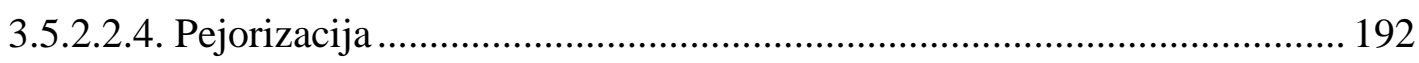

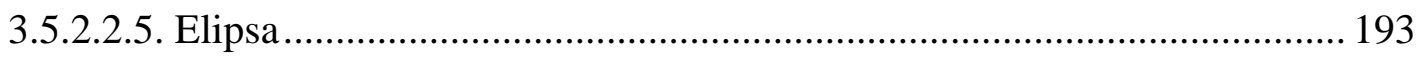

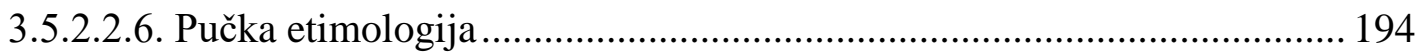

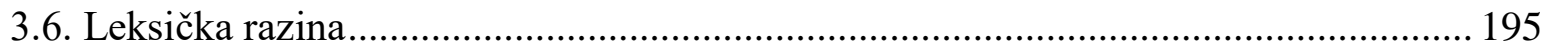




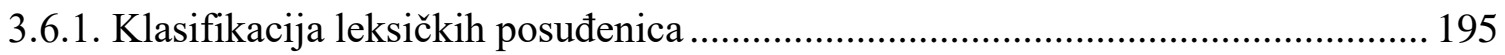

3.6.2. Zastupljenost turcizama u jeziku dvostiha ........................................................ 196

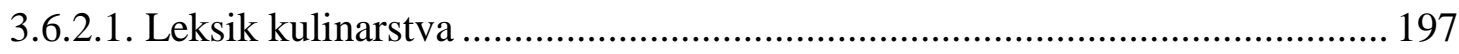

3.6.2.2. Leksik odjevnih predmeta, ukrasa, nakita i tekstila .................................. 197

3.6.2.3. Leksik kućnoga inventara i imenovanja prostora i okućnice ......................... 198

3.6.2.4. Leksik botanike i vrtlarstva, poljoprivrede, obrtništva i vojništva................ 199

3.6.2.5. Leksik pogrdnih imena, nadimaka i osobina................................................ 200

3.6.2.6. Leksik međuljudskih odnosa i osjećaja ..................................................... 201

3.6.3. Zastupljenost germanizama u jeziku dvostiha ..................................................... 201

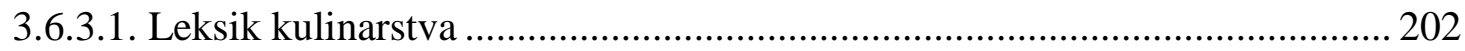

3.6.3.2. Leksik odjevnih predmeta, ukrasa, nakita i tekstila .................................. 203

3.6.3.3. Leksik kućnog inventara i imenovanja prostora i okućnice.......................... 203

3.6.3.4. Leksik botanike i vrtlarstva, poljoprivrede, obrtništva i vojništva................ 204

3.6.3.5. Leksik pogrdnih imena, nadimaka i osobina............................................... 205

3.6.3.6. Leksik međuljudskih odnosa i osjećaja ...................................................... 205

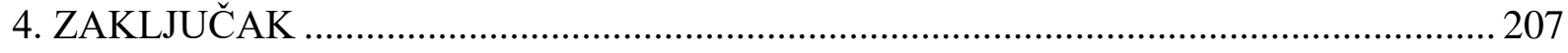

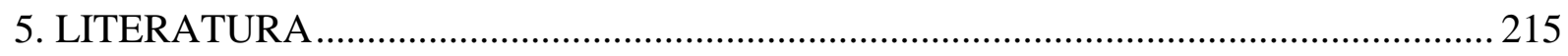

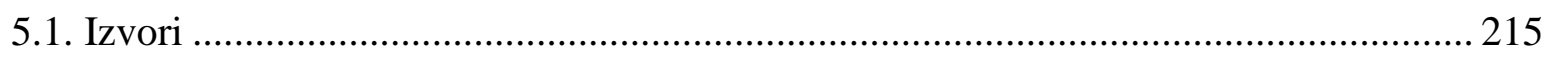

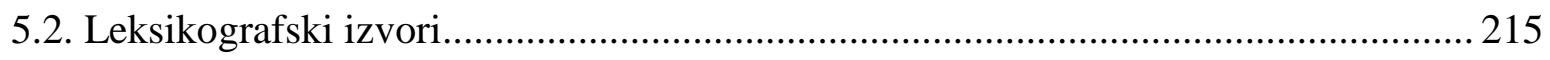

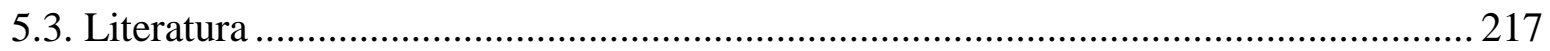

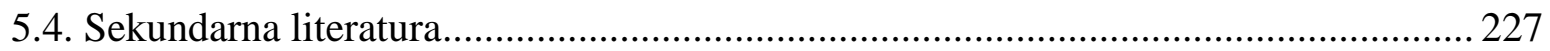

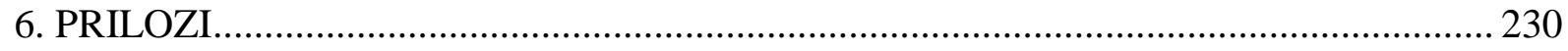

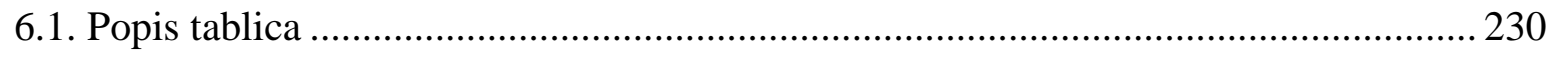

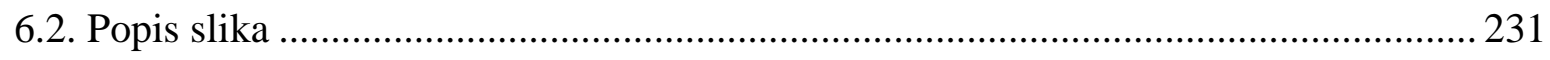

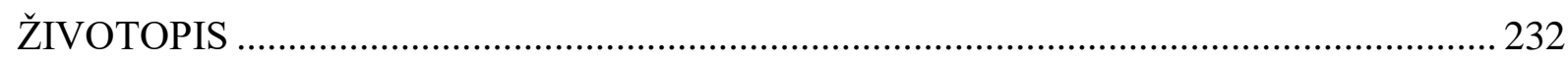

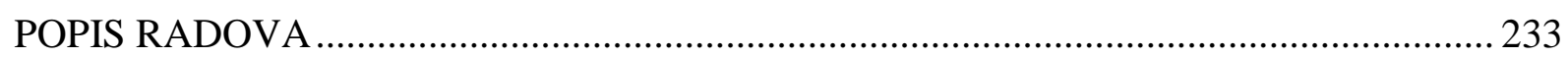




\section{UVOD}

\subsection{Tema, ciljevi i hipoteze disertacije}

Deseterački dvostisi Slavka Jankovića i Luke Lukića vjerodostojni su prikaz života, kulture i običaja na području Slavonije, Baranje i Srijema do sredine 20. stoljeća. Ta vrijedna ostavština s oko 8.000 dvostiha pruža relevantan uvid u leksik toga vremena te pokazuje zastupljenost stranojezičnih elemenata i njegov utjecaj na autohtoni leksički sloj. U disertaciji se istražuju leksičke značajke dvostiha iz prikupljenoga korpusa s osobitim obzirom na polisemičnost, homonimičnost i sinonimičnost te propituje utjecaj posuđenica iz njemačkoga i turskoga jezika na sadržaj i strukturu dvostiha. Posebna pozornost usmjerena je na problematiku međujezičnih dodira, jezično posuđivanje, prilagodbu posuđenica na fonološkoj, morfološkoj, semantičkoj i leksičkoj razini. Prikupljeni korpus čine Jankovićevi tiskani zapisi dvostiha te neistražena i jezično neopisana rukopisna ostavština Luke Lukića čineći tako iznimno bogatstvo gotovo zaboravljenoga pučkog govora Brodskoga Posavlja.

Cilj je disertacije stoga iscrpan pregled, opis i analiza utjecaja turcizama i germanizama na oblikovanje deseteračkih dvostiha na području Slavonije, Baranje i Srijema, s osobitim obzirom na značenjski potencijal leksema i pridavanje pozornosti homonimiji, sinonimiji i polisemiji u prikupljenome korpusu. Također je cilj disertacije poredbenom analizom tekstova usporediti zapise dvojice autora te opisati pojedine pravopisne, gramatičke, odnosno fonološke, morfološke, rječotvorne, sintaktičke i leksičke značajke.

Prvom se hipotezom tvrdi kako je u uspoređivanim dvama korpusima do sredine 20. stoljeća raširenija polisemičnost od homonimičnosti te homonimičnost od sinonimičnosti. Drugom se hipotezom tvrdi kako u deseteračkim dvostisima do sredine 20. stoljeća turcizmi dominiraju nad germanizmima, od leksika kulinarstva i odjeće preko kućnoga inventara, botanike i vrtlarstva te mnogih drugih grana poljoprivrede i obrta do pogrdnih imena, nadimaka i osobina te međuljudskih odnosa i osjećaja.

\subsection{Struktura i metodologija rada}

Hipoteze ove disertacije provjeravane su na prikupljenome korpusu od 8.000 dvostiha iz zapisa Slavka Jankovića, jednoga od najpoznatijih hrvatskih etnomuzikologa svojega doba i rukopisa Luke Lukića, najznačajnijega etnografa, melografa i folklorista u Slavoniji od kraja 19. stoljeća pa sve do sredine 20. stoljeća (Blaževac-Pajkov 2016). Ta su dva korpusa različito 
oblikovana. Dok su Jankovićevi zapisi otisnuti u trima pjesmaricama (Janković 1967, 1970, 1974) i lako su dostupna, Lukićevi su dvostisi dio rukopisne ostavštine čuvane u Muzeju Brodskoga Posavlja na Etnografskome odjelu u Slavonskome Brodu, Institutu za etnologiju i folkloristiku te Odsjeku za etnologiju Hrvatske akademije znanosti i umjetnosti. Jankovićevi i Lukićevi deseterački dvostisi do sada nisu bili predmetom lingvističkoga proučavanja i vrednovanja, stoga je potrebna njihova detaljna analiza, verifikacija i evaluacija.

U radu se istražuju leksičko-semantički odnosi leksema s posebnim osvrtom na sinonimiju, homonimiju i polisemiju, analizira i utvrđuje kulturno-povijesni okvir jezika u dodiru, odnos domaćih i posuđenih riječi, njihovo usvajanje i prilagodba na fonološkoj, morfološkoj, semantičkoj i leksičkoj razini te prosuđuje u kolikoj su mjeri posuđenice utjecale na jezik deseteračkih dvostiha i na kojim su semantičkim poljima dokumentirane. Također se u disertaciji kroz analiziranu rukopisnu ostavštinu Luke Lukića i tiskane zapise Slavka Jankovića provodi raščlamba pravopisa i gramatike starih govora te se opisuju pojedine pravopisne, gramatičke, odnosno fonološke, morfološke, rječotvorne, sintaktičke i leksičke značajke. Dvostisi nastaju spontano „uz kakve životne prigode: uz obrede i običaje, uz rad, dokolicu, šalu i trenutne zanose, uz svadbe, rođenja, umiranja..." (Botica 1995), dakle u svim prilikama i situacijama koje su bile dio svakodnevice staroga šokačkoga svijeta. Budući da prirodu dvostiha karakterizira i dokumentiranost i informativnost unutar kojih se mogu iščitati objektivne činjenice te rekonstruirati mjesto i vrijeme radnje, određene podatke o povijesti, povijesnim događajima (Barišić 2016a), politici i političkoj situaciji, ekonomiji, trenutačnoj gospodarskoj situaciji i tekućim društvenim problemima, očekivala se zastupljenost posuđenica $u$ raznovrsnom leksiku koji se ponajprije odnosi na kulinarstvo, odjevne predmete, ukrase, nakit i tekstil, kućni inventar, okućnicu, botaniku, poljodjelstvo, obrtništvo, vojništvo, ali i imena, međuljudske odnose i emocije.

U početnoj se fazi istraživanja podrobno istražila strana i domaća recentna literatura koja se ponajprije bavila jezičnim dodirima i složenošću leksičko-semantičkih odnosa. Potom se iz prikupljene građe koju čine tiskani zapisi Slavka Jankovića i rukopisna ostavština Luke Lukića oblikovao korpus deseteračkih dvostiha. Korpus je, koji čine „ti mali literarni dvostihovi u kojime se slijeva sve ono izvorno mjesno, sve one silnice koje tvore mjesnu identifikaciju“ (Botica 2013), postao okosnicom za proučavanje građe s jezikoslovnoga motrišta. Disertacija donosi i detaljni opis i analizu, do sad neistražene, rukopisne ostavštine dvostiha Luke Lukića. 
Središnji dio istraživanja posvećen je analizi korpusa. Za opis se deseteračkih dvostiha uglavnom koristila komparativna metoda, a navedene su se hipoteze verificirale induktivnodeduktivnom metodom. Prvo su se odredila teorijska polazišta i definirali deseterački dvostisi te analizirali leksičko-semantički odnosi s posebnim osvrtom na sinonimiju, homonimiju i polisemiju unutar prikupljenoga korpusa. Preliminarna istraživanja upućivala su na to da $\mathrm{u}$ tekstu deseteračkih dvostiha nema puno sinonimnih i homonimnih leksema dok su polisemni leksemi daleko zastupljeniji, a veliki je broj i onih koji nisu zabilježeni u hrvatskim leksikografskim priručnicima. Važan dio rada obuhvaća lingvistiku jezičnih dodira prema teorijskim uporištima hrvatske kontaktološke literature. U disertaciji se istražuje povijest hrvatsko-osmanskih i hrvatsko-njemačkih jezičnih dodira, analizira jezično posuđivanje, njegovi uzroci, prilagodba posuđenica i njihov utjecaj na leksik deseteračkih dvostiha.

Zaključno su sintetizirane glavne spoznaje i ovjerenost hipoteza, a s obzirom na neistražene segmente korpusa unutar navedenih područja leksikologije, moglo se predvidjeti dokumentiranje leksema iskoristivih za dopunu rječničkoga opisa hrvatskoga jezika.

\subsection{Pregled dosadašnjih znanstvenih spoznaja i istraživanja}

Deseterački su dvostisi kao svojevrsna lirska forma najrašireniji na području Slavonije, Baranje i Srijema i „,pokazatelj (su) obilja hrvatskoga narodnoga blaga“ (Botica 1996) te promicatelji višestoljetne tradicije i kulture. Kako „imaju specifičnu melodijsku, morfološku, sintaktičku i semantičku prepoznatljivost“" (Botica 2013) zahtijevaju svojevrsni jedinstveni pristup pojedinih znanosti.

Dok su s etnomuzikološkoga stajališta detaljno opisani te unutar te znanosti postoji stanovita raznolikost pristupa i tema istraživanja i znanstvenoga bavljenja desetercima, s književnoteorijskoga se motrišta deseteračkim dvostisima pristupa uglavnom ograničivši ih najčešće samo na bećarce. U nekoliko su monografija (Krpan 1996, 1999, Grgurovac 2005, Toldi 2013) objedinjeni kao tiskani zapisi, u monografiji Josipa Užarevića (2012) svrstani su unutar skupine književno minimalističkih žanrova, Pšihistal (2008) raščlanjuje kodiranje ljubavi u zbirkama Šokačke pismice Slavka Jankovića, Dragić (2008) kratko definira bećarac dok člankom u časopisu Užarević (2009) problematizira poetiku bećarca i njegove karakteristike. U okviru je te literature bećarac određen kao rimovani deseterački dvostih, tradicijski vokalno-instrumentalni slavonsko-baranjsko-srijemski minimalni napjev (Užarević 2009: 111). Bošković-Stulli (1978: 305) sugerira kako je nastao negdje u drugoj polovici 19. 
stoljeća, a Leskovac (1968: 107) upozorava da je bećarac situiran regionalno (od Srijema, Banata i Bačke s Baranjom preko Slavonije i Šokadije do Korduna i Like) smještajući ga i lokalno šire od onoga što je ovom disertacijom zahvaćeno. Dok Botica (2013) kratke dvostihovne pjesm(ic)e, a među njima i bećarac, smatra posebnima i vrlo plodnim vrstama lirskih pjesama, prema Dragiću (2008: 127) mnogi od bećaraca pripadaju pučkoj književnosti i nemaju estetsku funkciju, a da su oni i više od pučkoga oblika zabavljanja ide u prilog i činjenica da ga je Ministarstvo kulture Republike Hrvatske uvrstilo 2007. na Listu zaštićenih kulturnih dobara, a 2011. upisan je i u UNESCO-ovu Listu zaštićene nematerijalne kulturne baštine.

Stoga, slijedom navedenoga, ostaje nejasno kako do sada deseterački dvostisi nisu bili predmetom jezikoslovnih zanimanja ni podrobnijih istraživanja. O leksičkome sloju deseteračkih dvostiha nema previše obavijesti u recentnoj jezikoslovnoj i filološkoj literaturi. Stoga je nužno u okviru leksikologije načiniti potrebna istraživanja.

Korpus deseteračkih dvostiha ove disertacije objedinjuje tiskane zapise iz zbirki Šokačke pismice Slavka Jankovića $(1967,1970,1974)$ i neobjavljen rukopis Luke Lukića. Sveukupno 8.000 deseteračkih stihova bećaraca, drumaraca, svatovaca, pokladaraca i dr. minimalističkih vrsta usmenoga pučkog izričaja. Preliminarna istraživanja potvrđuju neke sličnosti i različitosti tih izvora. Lukićev rukopis postankom je stariji, a ako se uzme u obzir da je Janković analizirao Lukićeve Popijevke iz okolice Slavonskog Broda (1919), ne čudi što se u njegovoj pjesmarici puno tih deseteraca ponavlja. Lukić je evidentirao deseterce užega Brodskog Posavlja uključivši Oprisavce, Varoš, Kanižu, Klakar, Ruščicu i Donju Bebrinu, a Janković opisao i prikupio deseterce iz pojedinih mjesta na području Slavonije, Baranje i Srijema. I jedan i drugi uz prikupljene dvostihe bilježe i notno pismo pojedinih dvostiha. Janković je sve deseterce objedinio terminom pismice, odnosno dvostihovi-deseterci dok ih je Lukić kategorizirao terminom priskočnice ili pjesme. I povjesničari književnosti prihvaćaju predloženu terminologiju poistovjećujući „,pismice“ i „,deseteračke dvostihove“ (BoškovićStulli 1978: 305). U radu se prihvaća naziv deseterački dvostisi ne ograničavajući ih isključivo na bećarac ili druge pojedine vrste jer se stihovi samo formalno razlikuju s obzirom na prigodu u kojoj su ispjevani ili lirski subjekt koji ih osmišljava. Sve vrste deseteračkih dvostiha karakterizira ista struktura, minimalizam, intermedijalnost, rima, šaljiv kontekst i natpjevavanje pa nije opravdano izdvajanje samo jedne vrste. 
Kako je rad ponajprije usmjeren na leksičke značajke, unutar strukture deseteračkih dvostiha razmatrali su se isključivo odnosi među riječima i posuđenice. Deseterci obiluju potonjima kako su pokazala i preliminarna istraživanja. Naime germanizmi i turcizmi čine oko $70 \%$ korpusa i njihova je analiza obuhvatila najveći dio rada. Kod definiranja vrsta posuđenica, priklonilo se terminu turcizmi nad orijentalizmima i tvrdnji Hanke Glibanović-Vajzović (1986: 141) da su „turcizmi sve riječi orijentalnoga i drugoga podrijetla primljene posredovanjem turskoga jezika, bez obzira na njihovu dublju etimologiju“. Nakon provedenih uvodnih istraživanja utvrđeno je kako je područje Slavonije, Baranje i Srijema bilo tijekom duge i bogate povijesti izloženo njemačkim i osmanskim stranim utjecajima koji su svoje tragove ostavili i u hrvatskome jeziku. Razlozi se tomu mogu pronaći u dugotrajnoj prisutnosti Osmanlija na području Slavonije od 14. stoljeća kada je hrvatski jezik došao u doticaj s osmanskim utjecajem, a kasnije istjerivanjem Osmanlija u 18. stoljeću osnivanju Vojne krajine koja je služila kao vojno-redarstveno područje obrane od Osmanlija (Moačanin i Valentić 1981). Tada je jedan jezik zamijenjen drugim, njemačkim (Žepić 1996). Slijedom dugogodišnjih povijesnih zbivanja i političkih promjena posuđenice njemačkoga podrijetla, tj. germanizmi su, zbog određenih kulturoloških, političkih $\mathrm{i}$ inih razloga postali jezičnom potrebom među pripadnicima doseljenoga njemačkog naroda i starosjedilačkoga stanovništva. Njihova je upotreba poboljšavala međusobno sporazumijevanje, ali i potrebu govornoga iskazivanja novih elemenata izvanjezične stvarnosti uvedenih ispreplitanjem dviju kultura (Kordić 2006).

S obzirom na navedene činjenice germanizmi i turcizmi deseteračkih dvostiha analizirani su na fonološkoj, morfološkoj, semantičkoj i leksičkoj razini ponajprije se oslanjajući na načela kontaktne lingvistike (Filipović 1979, Filipović 1986, Dabo-Denegri 1998, Sočanac 2004, Stojić 2008). Da bi raščlamba bila potpunija, usporedili su se fonološki i morfološki sustavi kontaktnih jezika te se utvrdilo kako je posuđenica prilikom integracije u sustav jezika primaoca oblikovala svoja značenja, kako se to značenje odnosi prema značenju modela u jeziku davaocu, do kakvih je promjena u procesu prilagodbe došlo i zašto su te promjene nastale. Analizirajući leksičku razinu jezične strukture, najbolje su se uočili učinci jezičnih kontakata dvaju jezika i utvrdilo na koji su dio leksika posuđenice ostavile snažan utjecaj (Barišić 2016b).

U disertaciji su se podrobno istražili i leksičko-semantički odnosi leksema s osobitim osvrtom na sinonimiju, homonimiju i polisemiju. Za razliku od sinonimije (Melvinger 1984, Petrović 2005) i polisemije (Raffaelli 2015, Tafra 2017) o kojima postoji brojna recentna literatura, pojavi homonimije (Samardžija 1989, Dobričević 2000, Tafra 2016) unutar 
hrvatskoga jezika još uvijek nije pridana dovoljna pozornost te time ni ona sama još uvijek nije jednoznačno definirana (Hudeček-Mihaljević 2009), što je ostavilo dovoljno prostora ne bi li se pojavu homonimije dosljednije i sustavnije obradilo u ovoj disertaciji. U radu se očekivalo bilježenje novih značenja uvjetovanih danim deseteračkim dvostisima kojima bi se mogla upotpuniti leksička građa te time pridonijeti semantičkome opisu leksema u leksikografskim opisima hrvatskoga jezika. 


\section{RUKOPISNA OSTAVS̆TINA LUKE LUKIĆA}

\subsection{Uvodne napomene}

Od velike je važnosti zabilježiti kulturno naslijeđe pojedinoga naroda jer ono u sebi čuva tekovine stvarane generacijama u kojima se ogleda sve što je nekada bilo i što se danas, nažalost samo spominje. „Kulturna je baština ukupnost postignuća, stečevina naslijeđena od naših predaka. A naslijeđe naših predaka pobuđuje zanimanje nas sada živućih, kako bismo propitali sebe i svoj smisao postojanja, kako bismo sebi u sadašnjosti i sebi u budućnosti učvrstili identitet, očuvali kulturu i kako bismo to prenijeli našim nasljednicima (Vuković 2011: 105).“ Propitujući i analizirajući sastavnice toga naslijeđa, lako se može doći do rekonstrukcije pojedinih detalja tradicijskoga života i običaja te stvoriti polazište za proučavanje mnogih segmenata tradicijske kulture i društva Brodske Posavine. Stoga je važno napomenuti kako kulturna baština može biti vrijedan izvor spoznaja ne samo etnomuzikologiji, etnologiji, a unutar nje folkloristici, već i kulturnoj antropologiji, sociologiji, povijesti, povijesti umjetnosti, arhitekturi i građevinarstvu, filologiji i jezikoslovlju, a i brojnim drugim znanostima.

Kulturno naslijeđe čine i usmene pjesme minijaturne forme ma koliko one sažete $\mathrm{i}$ jednostavne bile. Govoreći o tim oblicima, jasno je kako je područje Slavonije, Baranje i Srijema, pa i šire, prepoznatljivo po deseteračkim dvostisima, tzv. ,cjelovitim lirskim usmenim strukturama“ (Botica 1996: 26). Dvostihe čine bećarci, svatovci, drumarci, pokladarci, bušarci i drugi minimalistički oblici, no mogu se determinirati općeprihvaćenom definicijom da su tradicijski vokalno-instrumentalni slavonsko-baranjsko-srijemski minimalni napjevi (Užarević 2009: 111), što i je službena odrednica bećarca. Njihovu strukturu čine dva deseterca koja „potpuno zaokružuju misao, determiniraju svijet pjesme i izvan tog svijeta takvim strukturama ništa drugo nije važno.“ (Botica 2013: 222) Ti se napjevi pjevaju i accapela i uz glazbenu pratnju tambura ili drugih tradicijskih instrumenata ${ }^{1}$, bez nužnoga kola kao sastavnoga oblika bećarskog zabavljanja, a pojavljuju se beziznimno u svim prilikama koje dopuštaju pjesmu. Pjevaju se u prošnjama, svatovima, seoskim prigodnim zabavama, kirvajima, drumskim ophodnjama, pudarenju ${ }^{2}$, divanima $^{3}$, pri raznim poslovima; čijalu, oranju, sadnji, žetvi, berbi i

\footnotetext{
${ }^{1}$ Gajde (frule).

${ }^{2}$ Čuvanje vinograda. Skok (1973: 68) bilježi: ,prema imenici pudar, gen. -ara m što znači 'čuvar vinograda i nekog drugog polja, bekčija (istočni krajevi)' prema f na -ica pudàrica 'žena njegova'“.

${ }^{3}$ Vijeće, sijelo, razgovor (otuda divaniti = razgovarati). Skok (1971: 410) bilježi: „divan², gen. -ana m (Vuk, 17. v.) $\gg 1^{\circ}$ tursko glavno vijeće $>$ vijeće uopće, $2^{\circ}$ kuća gdje se čini vijeće, $3^{\circ}$ govor uopće (isti semantem i u $z b o r$,
} 
kopanju zemlje, na ispaši, u vrijeme Uskrsa, Božića i u svim drugim situacijama ${ }^{4}$ koje su bile dio svakodnevice staroga šokačkog svijeta. Ispjevani događaj u desetercu sadržava elemente dokumentiranosti i informativnosti te se iz njega mogu iščitati objektivne činjenice te rekonstruirati mjesto i vrijeme radnje, određene podatke o povijesti, povijesnim događajima ${ }^{5}$, politici i političkoj situaciji, ekonomiji, trenutačnoj gospodarskoj situaciji, tekućim društvenim problemima i slično:
Mnogo ljudi živi u obijesti,
Upadosmo u veliku krizu,
Dvotarifna brojila za vodu
neće im se crna kruva jesti.
a izlaza ne vidimo blizu.
predstavljaju najnoviju modu.

Sam tekst deseteračkih dvostiha svojim sadržajem može upućivati na prikriveno značenje rečenoga ${ }^{6}$, a autori i recipijenti pjesmica sami se mogu prepoznati u njima što im ostavlja prostora za daljnju igru riječima, koketiranje i sve ono što je čednomu narodu tada bilo neprihvatljivo:

Lipo ti je spavat u šljiviku
još kad nađem moju lipu diku.

\begin{abstract}
Vidi tamo - s rogovima bena, rogonja je, jer ga vara žena.
\end{abstract}

Dakle, funkcija deseteračkih dvostiha dominantno je animirajuća. Ti napjevi ne samo da zabavljaju, razonođuju, informiraju recipijente, tj. implicitno im daju do znanja određeni stav, svjetonazor ili stanje stvari, a od njih izazivaju povratnu informaciju, reakciju, stav prema

\footnotetext{
zboriti, v.)«. Posljednje značenje divan (Lika) = divân, gen. divana $(\check{Z} \mathrm{~K})$, odatle denominativ (faktitiv) na -iti impf. divaniti, dîvânîm (17. v.) = divānit(ī) $(\check{Z} \mathrm{~K})$ »razgovarati, govoriti«, s prefiksom raz- pf. razdivaniti se, -dîvânîm (Lika, Vinkovci), deminutiv na -kati divànkati, -ām (Lika)“.

${ }^{4}$ Razne situacije diktiraju i razne sadržaje tih minijaturnih formi u kojima se opjevava ljubavna tematika, udaja, ženidba, običaji, rodbinski odnosi, ratarski i drugi poslovi, gizda, moda, služenje vojske i sl.

U stihovima koje je zabilježio Slavko Janković opjevava se i bolest i siromaštvo i smrt te različite vrste drugih zapreka ili smetnji kako ih je i on sam nazvao (Janković 1970: 119) poput vojske, rata, rastanka i udaljenosti, nepovoljne rodbine, sela, zlotvora i sl. što je jasno vidljivo i iz ovih stihova: Moja mi se razboljela lola,/nema lika, umrt će mi dika.

${ }^{5} \mathrm{Na}$ tu je činjenicu upozorila Barišić (2016a) člankom u kojem je podrobnom komparativnom analizom rimovanih deseteraca i nekih drugih tekstova, poput povijesnih monografija, kronika i kataloga, autobiografskih izvora samih sudionika rata pokazala da je taj pjesnički oblik dobar izvor, zrcalo ili prozor u svijet ratnih zbivanja Prvoga svjetskoga rata. Odlična podloga za istraživanje kako povijesnih činjenica, primjerice izgleda ratišta, lokacija i oblika ratovanja, ratnih tehnika poput rovovskog ratovanja, prisilnog ili dobrovoljnog zarobljavanja neprijatelja, ratne mašinerije i artiljerije poput bombi, mitraljeza, pušaka, bajuneta, granata, teškog topništva tako vjerno donosi i opise gospodarske i političke situacije u zemljama te političke suverene i njihove postupke.

${ }^{6} \mathrm{O}$ prikrivenim značenjima leksema i prijevodu bećarca na engleski jezik više u Barišić, Ana Tereza i Makaj, Zorana (2015).
} 
čemu ili komu, njima se pak može nekoga i pohvaliti, naružiti, uplašiti, ohrabriti, posavjetovati, ismijati, zavesti:

$$
\begin{aligned}
& \text { Ajmo, ljudi za Matom u kuću, } \\
& \text { snaša peče pogačicu vruću?. }
\end{aligned}
$$

Bećarac u pravilu započinju, uvjetno rečeno, samo najbolji i najodrješitiji pjevači (muškarci i žene) koji pjevaju prvi stih, a ostali pjevači ponavljaju taj stih s melodijskom varijacijom; isto se događa i s drugim stihom (Užarević 2009: 113). Kada se u bećarcu govori o lirskome subjektu, na temelju proučavanih pismica ispada prema gruboj procjeni, da ih je više od dvije trećine ispjevano iz ženske perspektive, tj. s motrišta ženskoga lirskoga $\mathrm{Ja}^{8}$ (Užarević 2009: 115).

Nerijetko su se te minijaturne forme smatrale nevrijednima bilješke, o čemu svjedoče i prvi zapisi ${ }^{9}$ melografa i etnomuzikologa koji deseterce nisu cijenili, priznavali niti detaljnije opisivali, a „danas, kada su i ganga, i ojkanje, i bećarac na UNESCO-ovu popisu svjetske nematerijalne kulturne baštine, taj je žanr valoriziran, 'iza tolikih godina za kojih skrovite bijahu' izrazio je autentičnu bit usmenoknjiževnoga fenomena: da ga vrijeme ne troši jer je najbolji izraz duševnoga pregnuća (Botica 2013: 223).“

Kolika je važnost izrečenoga, a zatim napisanoga i tako trajno otisnutoga shvatio je još u prošlome stoljeću rijetko spominjani, a nerijetko i nepoznati etnograf, melograf i folklorist Luka Lukić ${ }^{10}$. „Ja sam mnoge godine čekao i željno izčekivao hoće li tko od pisaca, književnika, pjesnika ili profesora obraditi i skupiti te lijepe i zanimive pjesme, ali sve badava - kroz 30 godina nisam to dočekao, onda sam to skupio i prepisao ja, kad drugi inteligentni ljudi nisu to uradili: ili ne znaju za te pjesme, ili nemaju vremena, da ih skupe i urede, ili im je to prosto, ili su jako zaposleni službom (OE HAZU NZ 5g: 1).“ Započevši, prema Osnovi za sabiranje $i$ proučavanje građe o narodnom životu Antuna Radića iz 1897. godine, bilježenje i najmanjih

\footnotetext{
${ }^{7}$ Stihovi se mogu tumačiti metaforički. Naime, Mato je nešto skrivio pa mu je potrebno društvo kako bi se ženina ljutnja (pogačica vruća) manje uočila i manifestirala prema krivcu.

${ }^{8}$ Da je tomu tako, pokazala je i autorica (2016a) člankom u kojem je zaključila da stihove nisu ispjevale bezimene žene koje su o ratu samo slušale, već one iste koje su te strahote i doživjele. Stoga, za razumijevanje, objašnjenje i tumačenje sadržaja bećarca s ratnom tematikom to je vrlo važan podatak. No, ovaj se zaključak odnosi samo na dvostihe ratne tematike. Prati li ta pojava i ostale dvostihe pretpostavka je što otvara prostor za daljnje istraživanje. ${ }^{9}$ Franjo Ksaver Kuhač (1878. - 1881., 1941.) ne navodi niti jedan zapis dvostiha, a deseteračke stihove svrstava u skupinu o razbojnicima i tatarima. Etnolog Josip Lovretić konkretno bećarac naziva noćnim muškim pjevanjem (Ceribašić 2013). Janković (1967) bećarce definira pjesmicama obično bećarskog, raskalašenog i pijanog sadržaja, a i sam ih Lukić (OE HAZU NZ 5a) proziva pijančevim pjesmama. Dakle, deseterci su bili izrazito negativno konotirani.

${ }^{10}$ O Luki Lukiću nema pregršt biografskih podataka, spominje ga Širola (1925), Bezić (1974), HadžihusejnovićValašek (1981), Krpan (1994), a nešto detaljniju biografiju bilježi Gajger-Krajnović (1991) i Blaževac-Pajkov (2016).
} 
detalja koji su činili kulturu i običaje sela Klakara u Brodskome Posavlju, a i šire, nije ni slutio koliki će obol ostaviti za proučavanje sveukupne kulturne baštine brojnim stručnim i znanstvenim interpretatorima, ali i zaljubljenicima amaterima. O svome skupljačkom poslu iskreno progovara: „Nisam nigda mislio, da ću se baviti tako opširno folkloristikom, kako sam počeo i kako se bavim. Ali drugi ljudi, običaji i način života ponukaše me, da sam se uzeo ozbiljno baviti tim poslom. Sprva sam bilježio samo pjesme, šale i kraće pripovijetke i to dosta nesustavno. Kad sam naišao na Radićevu “Osnovu“" za sabiranje građe, porodi se u meni želja i stvori odluka, da opišem potanko sve i sva, što je u ovom selu važno i što vrijedi ubilježiti. (OE HAZU SZ 128a: 1).“

„Genij Luka Lukić i njegov predani rad u kojem je temeljito, do u najmanji detalj, opisao građevine, sprave, oruđa i pribor otrgnuo je od prolaznosti i zaborava ono što je postojalo u stvarnosti, odnosno to što sada postoji kao drugi oblik stvarnosti - kao pisana baština (Vuković 2011: 105).“

\section{2. Životopis Luke Lukića}

Luka Lukić rodio se 4. prosinca 1875. u Brodskome Varošu kao potomak stare brodske obitelji iz nekadašnje Gornje Varoši (zapadnog dijela Broda). Nižu pučku školu završio je u rodnome selu, a u Brodu tadašnju Dječačku školu. Kao stipendist Brodske imovne općine 1894. završio je Kraljevsku učiteljsku školu i vježbaonicu u Petrinji. Kao učitelj svoj je posao započeo u Kaniži, selu uz Savu, udaljeno nekoliko kilometara od Slavonskoga Broda. Tu je djelovao pune tri godine, a zatim je po kazni ${ }^{11}$ 1897. premješten u selo Brezine kod Pakraca. „Lukića čeka golem posao u novonastaloj školi koja ima 48 učenika, a vrlo malo pomagala i popratnih sadržaja potrebnih za kvalitetno održavanje nastave (Blaževac-Pajkov 2016: 17).“ Iz Brezine je potom izmješten u susjedno selo Gaj gdje je boravio svega četiri mjeseca. Ubrzo je nakon pozitivno riješene molbe 1900. kao 25-godišnji učitelj premješten u Klakar, istočno od Slavonskoga Broda, gdje je ostao 37 godina. Predavao je u Nižoj pučkoj školi, bio orguljaš u mjesnoj crkvi sv. Jakoba, bilježio sve o životu, zabilježio izvorni govor i običaje „svojih sela“, priče, melodije pjesama, sve što je činilo svakodnevicu mještana sela Klakara i okolice. Tako je, boraveći u Klakaru i tamo službujući, imao priliku biti sudionikom svih značajnih događanja

11 ,... kazne radi, što nisam mogao natjerati dva čovjeka /Imru Štivića i Matu Sokolovića/ da glasuju za vladina kandidata (OE HAZU NZ 5a: 9).“ 
tijekom cijele godine. Kao učitelj bio je jako cijenjen pa se rado priključivao gotovo svim poslovima i radovima svojih sumještana, obavljao je poljske sezonske poslove, berbu grožđa, prisustvovao svadbama, proslavama crkvenih blagdana i sl., o čemu i piše: „Kao mlad čovjek išao bi češće u goste u selu kad su svatovi/ na večeru/ na svinjokolju, kad se kuća diže, kad je berba ili na kakvu čast, došao bi na večeru a to zato da čujem koju zgodnu pjesmu ili ariju. (...) Isto tako, kad bi bile molbe, pa bi se kosilo, kupilo sijeno, kupile šljive, išli u berbu ili u ribu, sve su to bile zgode, da se nješta profitira i napiše u kajdanku (OE HAZU NZ 5a: 11).“ Tako je zabilježio potpuniju sliku svakodnevnoga života i običaja žitelja sela Klakara. Umirovljen je 1937. s 42 godine učiteljskoga staža. Vratio se u Varoš i nastavio zapisivačko-spisateljski rad dovršavajući mnoge započete spise koje je prvom prilikom bilježio pretežno stenografski. Preminuo je u Varošu 28. travnja 1956. Gajger-Krajnović (1991: 10) zaključuje kako je prema veoma opsežnome melografskom opusu, kao i cjelokupnoj građi koju je za sobom ostavio živeći i djelujući u narodu, Luka Lukić narodne napjeve, instrumente, običaje, nošnju i usmeno stvaralaštvo bilježio i opisivao gotovo tijekom čitavoga života.

\subsubsection{Stvaralaštvo i ostavština Luke Lukića}

O bogatom se zapisivačkome i prikupljačkome poslu Luke Lukića saznaje iz međusobne korespondencije s Vinkom Žgancem ${ }^{12}$, melografom, muzikologom, etnomuzikologom, zapisivačem narodnih plesova, obreda i običaja i ravnateljem i osnivačem Instituta za narodnu umjetnost u Zagrebu ${ }^{13}$. A do intenzivne suradnje došlo je posredstvom Marka Singera. „U to me posjeti iz Broda g. Marko Singer, povjerenik za prosvjetu kod gradskog N.O. u Slavonskom Brodu. On pregleda moje stvari, za par dana metne to u novine /Brodski list/ a uz to javi Min. Prosvjete u Zagreb, a i Prosvjetnom Odjeljenju kod oblasti u Osijeku. Ministarstvo prosvjete pismeno zatraži od mene, da pošaljem ili njima ili Jugoslavenskoj Akademiji u Zagrebu rukopis, što imam gotovo napisano. Ja sam to dopunio i poslao u Zagreb, a onda tražio od Akademije notenpapira. Ona mi nije odgovorila već to ustupila Institutu za narodnu umjetnost. Tamo je bio glavni radnik g. dr. Vinko Žganec (OE HAZU NZ 5a: 13).“

\footnotetext{
${ }^{12}$ Hadžihusejnović-Valašek (1981: 85) naglašava kako ,njihovo dopisivanje iz 1951. godine predstavlja za znanost dragocjenu dokumentaciju o životu ovog osamljenog pregaoca, o njegovoj ljubavi prema narodnoj umjetnosti uopće, a nadasve o presudnoj ulozi dr. Vinka Žganca kao predstavnika Instituta za narodnu umjetnost (INU) i Jugoslavenske akademije znanosti i umjetnosti (JAZU). Preko svojih pisama dr. V. Žganec bodri već gotovo slijepog starog učitelja, upućuje ga na način bilježenja i transponiranja melodija, uspijeva ishoditi otkup originalnih rukopisa za Jugoslavensku akademiju znanosti i umjetnosti. Na taj način je kompletiran i spašen njegov rad i jedna od najopsežnijih zbirki melografskih zapisa u Hrvatskoj.“

${ }^{13}$ Danas Institut za etnologiju i folkloristiku.
} 
Da je Žganec uočio izuzetnu vrijednost poslanih araka te inzistirao da Lukić nastavi transponirati i prepisivati zapise narodnih napjeva prema dobivenim uputama na melografske kartice, saznajemo iz predgovora Lukićeve zbirke: „Ja sam Lukiću na njegova pisma redovito odgovarao i davao mu upute za rad, bodrio ga i savjetovao. Naročito sam ga upućivao da si čuva zdravlje i vid i višeputa ga zamolio: neka nama u Institut pošalje svoje bilješke, pa ćemo iz njih mi prepisati tekstove. On je sve to otklonio i u svojoj dubokoj starosti - uz sve životne nedaće - nastavo je marljivo ko mrav da radi na dovršenju svoga melografskog djela (IEF rkp N124/1: 5.).“

Cjelokupna Lukićeva rukopisna građa obuhvaća preko 10000 stranica, a čuva se najvećim dijelom u Muzeju Brodskog Posavlja ${ }^{14}$ u Slavonskome Brodu, u Institutu za etnologiju i folkloristiku ${ }^{15}$, Odsjeku za etnologiju Hrvatske akademije znanosti i umjetnosti u Zagrebu, Matici hrvatskoj i u privatnim zbirkama. Veliki je to fundus koji obiluje ne samo narodnim napjevima, već slijedom Osnove građa obuhvaća cjelovit opis života zajednice i njezinu cjelovitu kulturu. Lukić navodi opise stambenih i gospodarskih zgrada i građevina i zgrada izvan dvorišta, opise sprava, oruđa i pribora, dio se odnosi na izrađivanje i održavanje zgrada, sprava i oruđa ${ }^{16}$, opisuje gospodarstvo sela Klakara dotičući se ratarstva i povrtlarstva, govedarstva, konjogojstva, voćarstva i ribolova, nadalje opisuje prehranu, nošnju svih dobnih skupina te umijeće odijevanja i tekstilnoga rukotvorstva. Daje nam uvid u društvene odnose opisujući život u obiteljskim zadrugama i običajno pravo, odnose sa susjedima i kumovima, rodbinske odnose. Popisuje i godišnje i životne običaje: svetkovine, crkveni god, slavljenje kućnoga sveca, poklade, križarice, porod, sklapanje braka, oblike zabave pa i smrt. Lukić je opisao razne igre djece i mlađih djevojaka i mladića, a spomenuo se i različitih vrsta bolesti, njihova liječenja i ljekovitih biljaka, opisao je magijska vjerovanja i postupke. Dio građe iz opisa sela Klakara obuhvaća korpus pučkih pjesama, tj. dulje vojničke pjesme, molitve i pripovjedne žanrove, tj. pripovijetke, kraće pripovijetke, priče, gatke, basne i šaljive pripovijetke - šale ${ }^{17}$.

Važno je spomenuti kako je Lukiću za života tiskano djelo Varoš - narodni život $i$ običaji u tri knjige Zbornika za narodni život i običaje Južnih Slavena 1919., 1924. i 1926.

\footnotetext{
${ }^{14}$ Blaževac-Pajkov (2016: 18) navodi kako je u Muzeju Brodskog Posavlja pohranjeno oko 3800 rukopisnih stranica Lukićeve ostavštine u kojima se ističu svojevrsni dnevnici koje je Lukić vodio tijekom Prvoga svjetskoga rata u Klakaru i Drugoga svjetskoga rata u Varošu, a nazvao ih je Novosti sela i okolice. Važno je napomenuti kako je u pripremi izdavanje spomenute rukopisne građe.

Detaljan i sistematičan popis ostavštine u Muzeju Brodskog Posavlja bilježi i Karolina Lukač (2017).

${ }^{15}$ U Institutu se čuva oko tisuću notnih zapisa tradicijske glazbe Brodskoga Posavlja te isto toliko i tekstova narodnih pjesama, a veći se dio te iste građe čuva u prijepisu Akademijinog Odsjeka za etnologiju.

16 Više u Lukić (2016a).

${ }^{17}$ Više u Lukić (2016b).
} 
godine, a većina rukopisne građe do 2016. godine ostaje neobjavljena kada se, zahvaljujući koordinatorima projekta „Kritičko objavljivanje Akademijine rukopisne ostavštine Luke Lukića“" dr. sc. Klementini Batini i Mati Blaževcu-Pajkovu, objavljuju tri monografije: Luka Lukić: učitelj, etnograf i melograf u Klakaru Mate Blaževca-Pajkova kao svojevrsni uvodnik u etnološku i folklorističku monografiju o Klakaru s vrlo obilnom rukopisnom građom imena, Opis sela Klakarja: graditeljstvo, pokućstvo, sprave i oruđa početkom 20. stoljeća i Opis sela Klakarja: pripovijetke i pjesme skupljane od sredine 19. do sredine 20 stoljeća. Dvije potonje pripremao je sam učitelj Lukić nazvavši rukopis Opis sela Klakarja i Narodni život Klakarje $^{18}$.

Osim s Jugoslavenskom akademijom znanosti i umjetnosti u Zagrebu, Maticom hrvatskom i Institutom za narodnu umjetnost, Luka Lukić aktivno je surađivao i s katoličkim glazbenim časopisom za crkvenu glazbu Sveta Cecilija od 1920. do 1936. u kojem piše osvrte i kritike za orguljašku glazbu, objavljuje članke o tradicijskome pjevanju kao i tekstove tradicijskih svjetovnih i crkvenih pjesama s notama ${ }^{19}$.

Od cjelokupne objavljene i neobjavljene Lukićeve rukopisne građe, zanimljiva je činjenica da se nitko nije zainteresirao za objavljivanje napjeva kratkih pučkih pjesama od dva, tri ili četiri reda, niti je itko toj građi znanstveno pristupio iako je nepresušni izvor brojnih informacija ${ }^{20}$, prije svega onih jezičnih. Naime, Lukić je skupljao napjeve kroz 56 godina vjerno ih bilježeći od 1893. do 1951. Pazio je da ih ispiše isključivo kako je čuo, ,,a ne, kako bi moralo biti, (...) točno i vijerno samo onako, kako narod pjeva i govori (OE HAZU 5a: 2).“ U svom je zapisivačkome i prikupljačkome poslu nastojao što preciznije dokumentirati zapisanu građu te je uz tekst i melodiju navodio i kazivača te vrijeme i mjesto nastanka teksta. Građa je zbog toga iznimno vrijedna ne samo za etnomuzikologiju ili etnologiju, već i za povijest, antropologiju,

\footnotetext{
${ }^{18}$ Lukač (2017: 192) bilježi kako je „monografiju Klakarje Luka Lukić sastavljao prema Radićevoj Osnovi od 1905. do 1952. U istom je razdoblju predao u arhiv ONŽO-a veći rad s folklorističkom građom. Nakon Drugoga svjetskoga rata odlučuje ju dopuniti Jakša Primorac. Arhivska građa odsjeka za etnologiju HAZU. Zbornik za narodni život i običaje, 55 (2010): 27.“

${ }^{19}$ Kompletnu Lukićevu bibliografiju bilježi Martina Krajnović (1991: 84-85) te Blaževac-Pajkov (2016: 153$155)$.

${ }^{20}$ Kao potvrdu tome može se istaknuti nekoliko činjenica na koje su upozorile Tanja Perić-Polonijo i Dunja Vanić u Uvodu svojevrsne monografije (2016b) izdvojivši iz Lukićevih pjesama nekoliko jezičnih slojeva u kojima su „sačuvane odlike staroga, srednjovjekovnoga hrvatskoga jezika“, brojni turcizmi, germanizmi, hungarizmi, ali i „riječi koje pripadaju idiomu hrvatskoga slavonskoga govora u samome Klakaru i okolici te brojni arhaizmi, zatim riječi koje su u međuvremenu promijenile značenje“. Korpusom prevladavaju i brojne inačice (badavad, bajdava i badava), ponekad se i u istom tekstu ostvaruju istoznačnice tipa ćako, dada, otac i babo; meštar i učitelj. Također ističu (2016b: 31) Lukićevu nesustavnost u zapisivanju glasa $d$ što vjerojatno ovisi i o vremenu sastavljanja pojedinih dijelova rukopisa. Nadalje zaključuju kako Lukić rijetko zapisuje šta, ko, niko dok sustavno bilježi što, tko, nitko, poslje, a ne poslije.
} 
ali prvenstveno za jezikoslovlje ${ }^{21}$ te bi se njezinom daljnjom obradom moglo doći do zanimljivih novih spoznaja.

\subsubsection{Lukićeve rukopisne zbirke pjesama}

U golemoj Lukićevoj rukopisnoj ostavštini veliki dio građe čine pjesme i notni zapisi pučke narodne pjesme i crkvene pjesme. Od pučkih pjesama bilježio je dulje pjesme različite tematike, „razne pjesme od 3 ili 2 reda, ponajviše od dike ili milana (OE HAZU NZ 5a: 9)“, ali i „bećarske i pijančeve (nav. dj.: 13)“. Lukić je evidentirao pjesme Brodskoga Posavlja uključivši Oprisavce, Zadubravlje, Podvinje, Gromačnik, Klakar, Ruščicu, Gornju i Donju Vrbu, Sibinj, Varoš, Kanižu, te Gornju i Donju Bebrinu. Bilježio je pjesme slušajući svoje sumještane pri raznim svetkovinama ili drugim prigodama ili su mu ih osobno kazivali sve s jednim ciljem „da te sve melodije lijepo prepišem i podnesem Jug. Akademiji u Zagrebu na čuvanje (nav. dj.: 15)“. Lukić je skupljao pučke napjeve sve do 1951., a sveukupno ih je obuhvatio u deset kajdanki. Navodi: „Napjeve pjesama, melodije sam razdijelio na pet dijelova i to tako: I. dio najstarije pjesme do g. 1890., II. dio od 1890. do 1915., III. dio od 1915. do 1920., IV. dio od 1920. do 1940., V. dio od 1940. do 1950. (nav. dj.: 15)““

Kako su u rukopisnim zbirkama zabilježene razne pučke pjesme i dulje i kraće, pozornost će se pridati samo kratkim pjesmama, konkretnije desetercima ili kako ih Lukić naziva priskočnicama, ali ponegdje i pjesmama. O napjevima saznajemo da ih je u Slavoniji puno, da nastaju jednostavno, brzo i lako: „Izmisliti i složiti pjesmicu od 2 ili 3 reda, to nije teško, to cure lako slože, koje imaju diku, pa i pjevaju ako i tiho bilo: 'Imam janje, imam milovanje, s njime svega, a ništa bez njega' (nav. dj.: 28).“

U pjesmama djevojke pjevaju i o drugim djevojkama i mladićima, o svemu što čini njihov svijet: „Osim o diki razgovaraju se cure i o drugim curama i momcima, kako se tko nosi, tko je s kim u zavadi, što se sad sve radi, što je u selu i u okolici, pa eto štofa za pjesmice (nav. dj.: 28).“ Tematski se razlikuju pa se u njima mogu opisati ljubavni jadi, prkos, želje, uspomene, ruganje inoči i sl. S obzirom na vrstu Lukić ih dijeli na lirske, epsko-lirske i epske: „Pjesme su najviše lirske, jer one iskazuju ono u par riječi, što pjevač misli i osjeća, pa to na lijep način kaže. (...) Ove su pjesme najbolje i najfinije u selu, pa kad ih čovjek iz grada čuje, čudi se i divi

\footnotetext{
${ }^{21}$ U prilog toj činjenici Lukić (OE HAZU SZ 128a: 2) bilježi „Koliko je bilo moguće, držao sam se, da sve napišem onako, kako svijet govori. To mi je, Bogu hvala, i uspjelo, pa će svatko, tko to bude čitao/a osobito razgovore/ reći u sebi: „Baš govori Klakarac.“- I taj svit opet drugačije govori, tako, da ima i u ovom malom selu više vrsti govora. Ja sam to kušao ubilježiti, koliko se je dalo.“
} 
tomu, od kuda prostom svijetu bez naobrazbe taj dar, da tako šta lijepo izmisli i zapjeva. Malo lošije su pjesme epsko-lirske, koje uz događaje izrazuju i svoje osjećaje; ali i one su dobre i dotjerane, da im nema prigovora. (...) Još se nađu u selu čiste epske pjesme, koje u desetercu opisuju seoske događaje: izbore, kradu, berbu, molbu, Pazar, ženidbu, udaju, čuvanje blaga, rabotu, prelo, kolo i ašikovanje (nav. dj.: 29). “ Sve su pjesme oblikom dotjerane i karakterizira ih rima na kraju stiha, iako se ona u nekim pjesmama može pojaviti i u sredini. Pjesme mogu pjevati i izmišljati i muškarci i žene, iako ih više izmišljaju žene kako navodi Lukić (nav. dj.: 29) te nastavlja: „Kod same pjesme nema drugih umetaka osim običnih koji diki kaže: zlato moje, milane, dragane, lolo, bećaru, janje, lalo i sl.“

Lukić je svjestan da je pjesama puno te uz pomnu sistematizaciju i preciznost $u$ bilježenju tekstova i arija skromno bilježi: „Ne mislim da sam sve pjesme zapisao, ostalo je toga još u narodu dosta, ali šta sam čuo i kako, to sam napisao, da se ne zaboravi (nav. dj.: 15).“ Nakon što ih je prikupio i zabilježio, poslao ih je Institutu za narodnu umjetnost na obradu, a dio je pjesama prepisan i dan Hrvatskoj akademiji znanosti i umjetnosti o čemu svjedoči i Uvod u zbirku Narodne popijevke iz okolice Slavonskoga Broda: „Ovu Zbirku od br. 1. do 952. poslao je Luka Lukić Institutu za narodnu umjetnost s time da se cijela zbirka prepiše u dva primjerka, jedan za Institut, a drugi za Jug. Akademiju. To je djelomično i učinjeno tako, da je prepisan jedan primjerak u cijelosti za Institut, a za Akademiju je prepisano od br. 1. do 353. i od 824 . do 908. Treba dakle prepisati ostalo za Akademiju, dakle u svemu 514 pjesama (OE HAZU NZ 5a: 1).“

U svoj svojoj obimnosti i izvornosti Lukićeve rukopisne zbirke pjesama, uredno posložene i strojopisom prepisane na odgovarajuće kartice i danas čekaju da nekome otkriju ljepotu očuvane kulturne baštine, ali i predstave nekadašnji pučki govor Brodskoga Posavlja, uvelike zanemaren.

\subsubsection{Dvostihovi iz Slavonije - priskočnice $^{22}$}

Lukić je zabilježio i pjesmice koje se danas u narodu nazivaju poskočicama, ali i njih naziva priskočnicama. To su obično dvostisi četrnaesterci i pjevaju se u kolu poslije dvostiha deseteraca. Bržeg su i življega tempa. Tematski se ne razlikuju od klasičnoga dvostiha deseterca. Lukić napominje kako je u proljeće 1888. njegova sestra Vera Lukić na poklon dobila

\footnotetext{
${ }^{22}$ Zbunjujući je podatak što se Lukić koristi u rukopisu terminom priskočnice i za klasične dvostihe deseterce, ali i za dvostihe koji se pjevaju u kolu, a nisu deseterci.
} 
Lovretićeve pjesme, ali su se tijekom godina izgubile. Nadalje (IEF rkp 53, str. 13) bilježi: „U g. 1940. nakon tolikih godina (므) ja se sjetio tih Lovretićevih pjesama, nabavim si bilježnicu, te ih, nekoliko sam se sjetio te ih napisao, da se ne zaborave, pa su tako došle i ove priskočnice na svjetlo. Ne znam pravo, je li te pjesme pok. J. Lovretić sam ishitrio, ili je čuo, pa bilježio, to će se već poslje saznati.“

U rukopisu su zabilježena 72 Lovretićeva dvostiha priskočnica iz kola, a Lukić je o njima napisao osvrt koji se u cijelosti prenosi.

O priskočnicama

„Od svih pučkih pjesama priskočnice su najljepše i zanimive, pa nije ni čudo, što se mnogi pitaju: kako one nastaju i zašto se govore u kolu i pocikuju.

Da dodje do pjesme, mora bit neki uzrok ili povod, a to je obično ovo: cure su vesele, njekom prkose, inoći, što se u selu dogodilo i pokladama ili u svatovima.

Sastanu se dvi druge u sobi na poslu (ruč. radu) pa se jedna drugoj potuži: „, Sinoć me je lola poljubio, mati to vidila, pa me iskarala, htjela me i bit, a ja sam joj rekla, da će me i dalje ljubit, pa šta je to, nije to nikako zlo. „Moja mati poludila, što me lola poljubila. “ A sad treba dalje složit, a i ta nije teška, kad se znade, da će ju i opet ljubiti. Zato i kaže: „Idi, mati, kupi tralje, ljubit će me i nadalje“ ili „Idi mati do nevolje, ljubit će me još i bolje. “ Sad je pjesmica gotova od 4 reda i može se govorit u kolu, a evo je: Moja mati poludila, što me dika poljubila. Idi, mati, kupi tralje, ljubit će me i nadalje. Ili to malo okrenu, pa govore: Moja mati poludila, što me lola poljubila. Idi mati do nevolje, ljubit će me još i bolje. To se tako u kolu govori i pocikuje, a druge joj dometnu: „,Kako ne bi pjevala, kad sam sinoć slušala, ge me mati iz potaje dike obećaje.

Priskočnice se govore i pocikuju poslje zapjevane koje pjesme, a nikada ne odma' čim se dodje u kolo i počme kolo.

Koja cura ne igra, nema momka, živi povučeno $i$ stidno, ta $i$ ne zna te pjesme izmislit i govorit, to znaju samo one, koje imaju dečke, pa im uvik imaju nešto da kažu, na samu ne mogu i ne smiju, nije zgoda i prilika, nego će reć' u pjesmi u par reda.

Nekad cura sanja, da je u kolu, pa se pjeva i govori, ona to pamti, pa kad se probudi, eto joj gotova pjesma, ne mora študirat, kako će i šta će zapjevat', kad dodje u kolo. 
Kad se trefi, da se zavade momci i cure, pa jedni drugima pjevaju rugalice, cure su ipak urednije, pa govore u kolu: ,, To i je, pa nek je, istina je, pa šta je? “ Priskočnice govore nekad i momci, ali to je već redje, ili bude s curama u društvu, a sami rijetko kad, gotovo nikad.

Kao druge pjesme, tako se i one puste u zaborav, pa se i ne spominju više, jer su sad došle nove, bolje i dotjeranije, tako bar mladež misli, ako i nije tako. Idu oni okolo po gradovi, pa čuju pjesme, dobro ih zapamte i doma u kolu pjevaju i govore.

Gotovo svakih 5 godina se priskočnice zamjenjuju novima, ako ih i nema puno, al se pjevaju $i$ govore zato, što su nove.

Najviše se te pjesme pjesmice govore od prkosa, inoće i dike (ljubavi). Naravno, da to sve bude u pristojnoj formi, a neće ni o pokladama da govoru javno (u kolu) što besramno ili nepošteno.

Dogodi se, ali baš redje, da se govori i ono, što nit je bilo nit će biti, ali je to u pjesmi, pa se dopušta i progledava.

Momci višeput izkreću te pjesme na svoj način, da nije onako, kako cure govore, onda bude smijeha i galame, ali to ubrzo prodje.

Ako bi neke djevojke rada, da se podiče sa tim pjesmama, a ne znaju ili nemaju gradje (štofa) za to - onda mrle babe ili stare majke, njekadanje pjevačice, da im pomognu sa par pjesmica, a one to obično urade i govore, cure pamte i u kolu se pohvale sa tim starim i već zaboravljenim pjesmama.

Napominjem još i ovo, da u selu znadu samo dvi ili tri cure izmišljati pjesme-obično one, koje imaju diku, a koje nemaju, one šute, ili misle, kako bi stekle dečke, pa i one s drugama u kolu pocikivale:

Svaka svoga momka ima, Moj ne more biti svima, samo meni primedeni.

kraj.

\section{Lukić} učitelj u miru 


\section{3. Životopis Slavka Jankovića}

O životu i radu Slavka Jankovića, s obzirom na njegov bogati stvaralački doprinos, mnogo se zna, ali je relativno malo i zapisano ${ }^{23}$. U pogovoru knjige Šokačke pismice III. Mirko Meštrović i Zlatko Virc (1974: 141-142) ističu: „Slavko Janković je bio izuzetna pojava u životu grada i Općine Vinkovci, a u određenim domenama kulturnog života predstavljao je vrhunac dostignuća i pregalaštva kulturnih radnika ovog našeg ravničarskog kraja. Bio je čovjek kojeg su vrlo dobro znale sve generacije Vinkovčana između dva rata. Rodio se u Novim Mikanovcima 1. siječnja 1897. godine. Osnovnu školu i Gimnaziju pohađao je u Vinkovcima. Završetkom mature odlazi na studije u Zagreb i 1917. se vraća kao diplomirani pravnik." Radio je jedno vrijeme u Vinkovcima kao sudac, a potom je premješten u Pregradu, kod Zagreba u druge službe gradskog poglavarstva Zagreba. Bio je i nastavnik tamburanja u učiteljskoj i Višoj pedagoškoj školi te je 1959. umirovljen.

O njegovom etnomuzikološkom radu bilježe (nav. dj.: 142): „Iako je još kao student počeo da sakuplja šokačke pismice, najveću skupljačko-zapisivačku aktivnost razvio je poslije oslobođenja. Na području etno-muzikologije postigao je i najveće uspjehe. Bio je mukotrpan posao kroz toliko vrijeme skupljati 'pismice', bilježiti i sređivati napjeve. U pripremi za izdavanje 'pismica' pokazao je smisao za sistematičnost i naučnu metodologiju u radu. Skupio je oko 16.000 stihova iz Šokadije i na taj način ih oteo zaboravu. Strpljivim radom dočekao je izdavanje dvije knjige Šokačkih pismica. Treća knjiga Pismica izlazi za devete Vinkovačke jeseni kojima je također Janković davao svoj doprinos za života. Šokačke pismice III su u narodu. Ali, od lipnja mjeseca 1971. nema među nama Slavka Jankovića. Umro je vodeći seminar za tamburaške sastave u Delnicama, za vrijeme predaha u radu kao sedamdeset i četiri godišnjak, ali do zadnjeg dana ostao je vitalan i vjeran poslu kojemu je posvetio najviše godina svog života i pored drugih, redovnih, poslova.“

Na kraju vrlo ekspresivno dodaju (nav. dj.: 142): „Zauvijek će njegovo djelo ostati vjeran dokument čovjeka koji je znao osjetiti, shvatiti i sačuvati izvornu riječ, glazbu i život ovog kraja."

\footnotetext{
${ }^{23}$ O životu, radu i pismicama Slavka Jankovića više u Švagelj (1967), Hadžihusejnović-Valašek (1981), Grgurovac (2005), Grgurovac, Živković (2007) te Rončević (2013).
} 


\subsubsection{Iz vlastita pera - o pismicama}

Zapisati onako kako narod pjeva i govori, onako kako je gdje čuo, bila je zadaća Slavka Jankovića koji je cijeli svoj život proučavao narodne pjesme, s posebnim naglaskom na kratkim pismicama. U kakvom je okruženju rođen, odrastao i živio najbolje pokazuje Švagelj (1967) predgovorom ističući ljepote Pobosuća, Pobiđa, Posavlja, krajine i paurije, opisujući širinu šokačkoga srca, sanje, nemire, strepnje, život Šokaca i Šokica i suživot s neizostavnom tamburom, kolom i pjesmom koja se ,prenosi istovremeno generacijama kao ponos i kristal vedrine našeg čovjeka (nav. dj.: 6).“ Švagelj naglašava važnost tih kratkih formi opisujući ih kratkim pjesničkim porukama koje su ,nosile i krepkost i reskost, tvrdoću i liričnost istovremeno. Toliko težnji je opjevano, isprovocirano, intenzivirano, zatreptano u rijeci užitaka, brige i volbe. I kraj birtije i u birtiji, i poslije napornih žetvenih dana, na svadbama i udajama, s počimaljama i barabama, u sumracima i pod oblacima, pod zvizdanom kada sve gori, s ciganima i čobanima, na ovom teškom grimizu jesenske krajine i u zelenoj harfi travnja kuca bilo ove pjesme, čiji fini tonovi s nužnim posavskim akutom zbore o neizmjerljivosti prostora i širokoj duši hrvatskog čovjeka u Slavoniji (nav. dj.: 6).“

Vođen tim pregnućem Slavko Janković u uvodu svoje prve zbirke Šokačke pismice I osjeća potrebu ponešto reći o kratkim pjesmama koje naziva pismicama jer „naziv poskočice nije dobar, jer se pjevaju i izvan kola, a tu vrst pjesmica narod zove podvikulje. One se ne pjevaju, nego samo ritmički izvikuju u kolu. Ne valja ni naziv bećarci jer označuje samo vrst napjeva a ne pjesme (riječi). Ni termin šalajke nije dobar jer označuje samo vrst napjeva po kojima se pjevaju pjesmice a na kraju se dodaje 'šalaj' (nav. dj.: 10). “Ističe kako su prikupljene pjesme zapostavljene, nezapažene i nedovoljno proučene jer „mislim da se takve kratke pjesmice sakupljačima nisu činile dovoljno vrijednima. Jedan od razloga bit će i to, što su sakupljači rijetko bili dovoljno muzički obrazovani, pa nisu uočili muzikološku vrijednost ovih pjesmica, koja je često veća no u epskim pjesmama a moguće i od dužih lirskih pjesama. Slijedeći će razlog biti u tom što kavanski svirači često izvode od takvih pjesmica baš one, koje su umjetnički najmanje vrijedne tzv. bećarske, raskalašene, pa i pornografske ('sramocke') Janković (1967: 9).“ Usprkos tim razlozima, napominje kako ih je samo u prvoj knjizi dvije tisuće, odnosno četiri tisuće stihova. Te su lirske pjesmice sastavljene od dva stiha (dvostiha), tj. dva deseterca. Iako vrlo kratke „to im ne smanjuje vrijednost, nego možda i povećava“ jer „ovakve pjesmice mogu se često usporediti s mudrim izrekama i poslovicama. To je možda najvrjednija vrsta proznog stvaralaštva, jer se u njoj odbacuje sve nebitno, a bitno se svede na najmanju mjeru (nav. dj.: 10).“ Zaključuje „da bi po svojoj brojnosti (kvantiteti) i vrijednosti 
(kvaliteti) morale biti svrstane u posebnu podvrstu lirskih pjesama (nav. dj.: 9)“ te „da ovu vrstu narodnih pjesama smatramo posebnom, vrijednom i vrlo brojnom podvrstom narodnih lirskih pjesama (nav. dj.: 10).“ Zato i upozorava da ih ,treba čitati pažljivo i s razumijevanjem. Ne treba ih smatrati 'sitnišem' niti primitivnim pjesništvom, jer u njima ima mnogo duhovitosti, simbolike, jezične ljepote i zanimljivosti, dubokih osjećaja, životne radosti, tuge ... one su vjeran odraz života našeg slavonskog sela iz vremena kad su nastajale (nav. dj.: 17).“

U uvodnim razmatranjima napominje kako je sistematizirao gradivo te ističe potrebu opširnije tumačiti ,pjesnička pravila i ukrase ${ }^{24}$ uvjeren da će i seljačka mladež rado upoznati pjesnička pravila kojih se mora držati svaki pjesnik“ pri čemu zaključuje „da stvaraoci narodnih pjesama zapravo uopće ne znaju spomenuta pravila, a ipak su stvorili toliko brojna prekrasna i muzička djela po uzoru starijih djela i snagom mladenačkih osjećaja (nav. dj.: 11).“ Pri tome bilježi kako se mladež u trenutku kreacije tih minijaturnih formi „samo oslanja na siguran osjećaj za pjesničku metriku i muzičku ritmiku (nav. dj.: 11)“ što dovoljno govori o iznimnoj i jedinstvenoj vrijednosti pismica.

U uvodniku jedno poglavlje posvećuje i narječju i govoru Šokadije. „Makar da su ove pjesmice iz nekoliko bliskih sela, ima među njima dosta govornih razlika. To je zato što su u Šokadiji pomiješana sela raznih govora štokavskog narječja. Šokci govore ikavicom, ekavicom i poluikavicom (nav. dj.: 18).“ Janković ističe neke od fonoloških i morfoloških značajki ${ }^{25}$.

Svakako je zanimljivi dio uvoda prve zbirke i životopis Slavka Jankovića, lirski oblikovan, u kojem iznosi brojne osobne podatke o porijeklu, djetinjstvu, odrastanju, školovanju, mukotrpnome životu u vrijeme Prvoga svjetskog rata kada se znalo zapjevati i zaigrati. „Uključio sam se u taj život, oblačio bratićeve rubine i gaće da ne popljesnive u ormaru. Najviše smo pjevali pjesmice na divanu i u kolu. Primijetio sam da skoro svaka djevojka ima nekakve listove iz neispisanih školskih teka, pune tih pjesmica. Pomalo sam pamtio sve više tih pjesmica, te da ne zaostanem za drugima, počeo sam ih i ja zapisivati u svoj notes (nav. dj.: 20 21).“

Na divanima je počelo aktivno Jankovićevo zanimanje za pjesmama. Tada je bio student prava u Zagrebu, no zbog teške gospodarske situacije i ratnih događaja, Janković je više vremena provodio u Vinkovcima gdje mu je 1917. kao studentu dodijeljena služba kontrolora

\footnotetext{
${ }^{24}$ To su pjesnički oblik i unutar njega pravilo slaganja riječi u stihovima, naglasak riječi, stanka, dvosložni srok. Od pjesničkih ukrasa Janković (1967: 11-17) spominje epitetone i poredbe. Više u Janković (nav. dj.).

${ }^{25}$ Upotreba glasa $h$, naglasci, zamjenice taj, ta, to, ovaj, ova, ovo, onaj, ona, ono, glagoli u infinitivu i sl. Više u Janković (nav. dj.: 18-19).
} 
kod vršaćih strojeva jer ,austrougarske vlasti donesoše propise o rekviriranju žitarica, odnosno pšenice (nav. dj.: 21).“ Koliko mu je ta služba značila objašnjava: „Gospodin kontrolor, tj. ja sjedi kod kantara, pazi tobože na vreće, a bogme više na cure koje nisu daleko. Čim zapjevaju koju novu, vadi notes i bilježi. Pravi kontrolor! Nije dosta divana subotom i nedjeljom. Ako se uzmogne malko i svaki dan, iako treba uraniti svakog dana u tri sata, najkasnije u četiri. G. kontrolor se naravno baš ne žuri uraniti, zato i organizira da bude divan (nav. dj.: 21-22).“

Tijekom godina Janković je skupio mnogo pjesmica, a premještajem službe suca u Hrvatsko zagorje dobiva priliku srediti ih. „Režem cijelu kopiju na sitne papiriće. 8.000 pjesmica, dakle isto toliko papirića, 200 pribadača, pa slaži na velikom stolu u vrste. Tamo gdje očekujem mnogo, bude malo i obratno. Npr. slažem sve na istu pribadaču koje spominju inoču. Isprva mi nije jasno koje vrste treba osnovati, no poslije se to samo nameće. Nezgodan posao. Poslagano stotine papirića. Ne smijem ni kihnuti, ni nakašljati se ni uzdahnuti, sve odleti i pobrka se. Tko li bi izračunao koliko vremena proguta takav 'hobi' (nav. dj.: 24)!?“‘

O teškoći razdiobe i slaganju pjesmica Slavko Janković bilježi: „Slaganje tog ogromnog broja pjesmica svakako je bilo potrebno abecedno, jer se čovjek bez toga uopće ne bi mogao snaći niti ustanoviti, nema li po koju od njih već zabilježenu dva ili više puta... Nije bilo dosta slaganje i štampanje po abecedi tim više, što bi monotono djelovalo čitanje nekoliko desetaka pjesmica, koje počinju istim riječima. Slaganjem po vrstama (a još uvijek po abecedi) postignuto je, da se sve svrstalo mnogo preglednije, pa su dobivene vrste nametnule slaganje unutar samih vrsta u podvrste ${ }^{26}$ (nav. dj.: 27).“

Da je Slavko Janković bio svjestan ozbiljnosti zanemarenoga narodnog blaga, ističe bilješkom: „Sigurno je da je kod nas učinjeno razmjerno malo u skupljanju narodnih popjevaka. Malo obzirom na veliku količinu materijala, a pogotovo malo obzirom na činjenicu, da je to ogromno blago kulturnog naslijeđa na rubu propadanja i nestajanja (nav. dj.: 29).“

\subsubsection{Stvaralaštvo Slavka Jankovića}

Hadžihusejnović-Valašek (1981) javnosti je predstavila Slavka Jankovića kao velikog glazbenog entuzijastu, pravnika, pedagoga i propagatora tamburaštva u Hrvatskoj te sakupljačem šokačkih distiha, tzv. pismica, a o njegovom etnomuzikološkome istraživanju i melografiranju u Slavoniji bilježi vrlo vrijedne podatke. Navodi (nav. dj.: 99) kako je Janković

\footnotetext{
${ }^{26} \mathrm{O}$ podjeli pjesmica u više vrsta i podvrsta pogledati u Janković (1967: 25-26).
} 
„od 1916. do 1941. skupio 8000 dvostiha i nekoliko napjeva, koje je harmonizirao za zbor HPD 'Relković' iz Vinkovaca, kojim je tada ravnao. Zbog nepreglednosti velikog broja stihova i nekompletnosti same zbirke, autor je dugi niz godina uzaludno pokušavao prezentirati javnosti svo bogatstvo skupljenoga materijala. Uz tekst, jedan od strukturnih elemenata pismica, Janković se neminovno susreo s drugom komponentom - glazbom.“ Tadašnje njegovo znanje o glazbi nije bilo na zavidnoj razini. No, njegovu sveopću angažiranost i predanost radu, pa i tom segmentu, prepoznali su prof. R. Matza i dr. V. Žganec koji su mu posebno pomogli u stjecanju muzikološkoga znanja, što bilježi i sam Janković (1967: 28).

„Sistematskim skupljanjem popijevaka, počeo se Janković baviti tek pedesetih godina od kada i datiraju njegove prve rukopisne notne zbirke deponirane u arhivama ONŽO i ZIF u Zagrebu (nav. dj.: 99).“ 1951. godine nastala je Jankovićeva prva zbirka Pjesme iz Iloka (ZIF N 137) koju čine 33 pjesme, no Hadžihusejnović-Valašek (nav. dj.: 100) pretpostavlja, budući da zbirka ne sadrži notni zapis, ,da je to tekstovna zbirka, i da ne pripada notnoj (N) arhivi, ili je pak notni materijal zagubljen." Stoga ukazuje na potrebu detaljnoga proučavanja Jankovićeve ostavštine, koja se najvećim dijelom nalazi u SIZ-u za kulturu u Vinkovcima ${ }^{27}$.

Kao prva kompletna Jankovićeva rukopisna zbirka narodnih popijevaka navodi se ona iz 1952. imenom 45 slavonskih narodnih popievaka (ONŽO NZ 19 i ZIF N126) koja je „skupljena u Slavoniji 1949. godine za Jugoslavensku akademiju znanosti i umjetnosti u Zagrebu, dok je jedan primjerak zbirke prepisan za potrebe Instituta za narodnu umjetnost (nav. dj.: 100).“ Terenskim je istraživanjem u Slavoniji, po nalogu JAZU, Janković 1954. i 1955. zabilježio tristotinjak napjeva složivši ih u dvije zbirke: Narodne pjesme iz Nijemaca u Slavoniji (ONŽO 58a) i Narodne popievke iz Privlake (ONŽO 58b).

Jankovićeva najopsežnija i najsloženija zbirka dvostiha s napjevima svakako je ona i jedina tiskana njegova zbirka. To su knjige Šokačke pismice I, Šokačke pismice II i Šokačke pismice III u izdanju Matice hrvatske u Vinkovcima. „To je djelo jedinstveno po sadržaju narodnih pjesničkih i glazbenih tvorevina i po opsegu štampanog materijala. Mnogo korisnih podataka Janković je unio u opširan uvod zbirke i popratne napomene uz svaku vrstu i podvrstu distiha. Za razliku od tekstovnog dijela zbirke, u koju je djelomično uvrstio i tuđe zapise ${ }^{28}$, napjeve je melografirao sam Janković. Napjevi su zabilježeni uglavnom nakon 1945. godine, i to u selima oko Vinkovaca i Županje, a manje oko Sl. Broda i Đakova (nav. dj.: 101).“

\footnotetext{
${ }^{27}$ Dio rukopisa pohranjen je i u Institutu za etnologiju i folkloristiku. Vidjeti rukopisnu bazu.

${ }^{28}$ Je li moguće da je u svoju zbirku uvrstio dijelom i Lukićeve dvostihe rukopisne ostavštine koja je tada bila dostupna u Institutu za narodnu umjetnost, ali i u JAZU, svakako je podatak za istraživanje.
} 
Osim prikupljenih stihova za četvrtu knjigu Šokačkih pismica koji se nalaze u SIZ-u za kulturu u Vinkovcima, dio ostavštine Slavka Jankovića obuhvaća i spise o glazbi, etnomuzikologiji, nogometu, šahu, literaturi, jeziku, kao i bilješke narodnih napjeva diljem Slavonije, galeriju poznatih ${ }^{29}$, rezultate nogometnih utakmica GŠK Cibalije, povijest mnogih športskih klubova u Vinkovcima te osobne dokumente ${ }^{30}$.

Kao nastavnik tambure brinuo se i za edukaciju svojih učenika te je, u svrhu bržeg i lakšeg obrazovanja, napisao nekoliko knjiga u kojima je razrađivao i podučavao osnovnu tehniku sviranja i glazbeno pismo. To su Vježbe za tambure u dva sveska, Tamburaška škola za samouke u glasilu Sloga te Škola za tambure u dvije knjige. U naslijeđe je ostavio i Pjesmice za predškolsku djecu uz klavir, harmoniku ili tambure te Zrnca: male skladbe za male tamburaške sastave, glasovir ili harmoniku.

\subsubsection{Doprinosi i zasluge Slavka Jankovića}

Da je još kao srednjoškolac pokazivao zanimanje za pjesmu i tamburu, kulturu i običaje svoga rodnoga kraja, potvrđuju Mirko Meštrović i Zlatko Virc (1974: 141): „Već u srednjoškolskim klupama počinje polako i postupno da se otkriva u Jankoviću osoba puna želje za radom, za pjesmom i tamburicom. U mnogim svojim radovima iz kulturnog, sportskog, glazbenog i društvenog života počinjao je kao diletant, da bi talentom i poletom vrlo brzo napuštao taj diletantizam“ te dodaju: „Od 1917. sudjeluje u osnivanju Diletantskog kazališta, prvog u povijesti naše lokalne kazališne umjetnosti. Godine 1923. pokreće list 'Cibalis' iz kojeg možemo crpsti građu za izučavanje života tadašnjih Vinkovaca i ljudi u njemu. Osnovna je nota zgode i dogodovštine u gradu koji se upinje da izraste od seosko-obrtničkog u gradsko naselje.“ Janković je u tom listu objavio oko 500 pjesmica pod imenom Narodna poezija.

Zaslugom Slavka Jankovića stvoren je 30-ih godina 20. stoljeća lik čič Andre, Šokca šaljivca koji govori lokalnim jezikom njegujući i čuvajući izvorni narodni govor. A o čuvanju tradicije i spašavanju velikog kulturnog blaga od propasti progovara i Vinko Žganec (1967: 614) naglasivši da ,autoru treba odati priznanje ne samo zato što je ovim zapisima spasio veliko kulturno blago od propasti nego i zato što je toj materiji dao odgovarajući sistem, objašnjenja i mogućnost čitaocu da se u mnoštvu lapidarnih stihova može odmah snaći.“ Njegovi su dvostisi

\footnotetext{
${ }^{29}$ Galeriju poznatih sačinjavaju opisi značajnih osoba iz hrvatske znanosti i kulture te značajne vinkovačke osobe.

${ }^{30}$ Sva ta građa obuhvaća razdoblje od 1919. do 1970., a nalazi se u 24. kut.
} 
„odraz vedrog, duhovitog i bogatog nazora na svijet našega naroda, a po svojem sadržaju, lapidarnosti forme i jasnoći izraza spadaju među bisere poezije (nav. dj.: 614).“

Slavko Janković, tijekom svoga bogatog istraživačkog života, posvetio se i glumi, režiji, vođenju tamburaških i pjevačkih zborova ${ }^{31}$, pisanju zagonetki ${ }^{32}$, humorističkih članaka i pjesama te komponiranju skladbi temeljenom na izvornom narodnom melosu ${ }^{33}$. Javnosti je poznata njegova drama „Generalna proba“ za vrijeme čijeg je uprizorenja izveden uglazbljeni svatovac, u osobnoj Jankovićevoj režiji. Osim te vrste napjeva, u svojim rukopisnim zbirkama spominje i bećarac koji označuje (1967: 15) „vrstom napjeva, a ne pjesmom“. Za muzikološki rad 1970. godine dodijeljena mu je Nagrada AVNOJ-a.

Osim sudjelovanja u kulturnome i društvenome životu grada Vinkovaca, Jankovićev doprinos prepoznatljiv je i u izumiteljskome miljeu. Naime, Jankovićeve troglasne kvintne tambure i danas su u uporabi iako ih sve više zamjenjuju suvremenije četveroglasne kvartne tambure ili vojvođansko-slavonsko-srijemski štim ${ }^{34}$, odnosno sustav. Također je svoj doprinos dao i u šahu, osnovao je Šahovski klub „Vinkovci“, izumio džepni šah za čije je potrebe osmislio šuplje šahovske figure, no danas nisu u uporabi.

\footnotetext{
${ }^{31}$ Janković je u HPD „Relkovič“ svoju djelatnost započeo prvo kao pjevač, ali ubrzo postaje rukovodeći te kao njegov dirigent dovodi društvo među najbolje u Hrvatskoj što potvrđuju i Meštrović, Virc (1974: 142), ali i sam Janković (1967: 22). O Jankovićevom uspješnom ravnanju orkestrom i njegovoj ulozi kao dirigenta te o uvođenju njegovih zborova $U$ slavonskom kolu, Podivanka u repertoar Zbora HK dokumentira Čunko (2017).

${ }^{32}$ Zagonetke je objavljivao pod pseudonimima Slavko F.B., Jakov V. Jenkić, Branimir Jovanković i Ć. Ivo k ...naj. Više u Horvat (1979).

${ }^{33}$ Više na http://selo.hr/slavko-jankovic/.

${ }^{34}$ Više u Ferić (2003).
} 


\subsection{Pravopisne i gramatičke značajke Lukićevih rukopisa i Jankovićevih zbirki}

Kako je Slavko Janković bio urednik ${ }^{35}$ pojedinih zbirki Instituta za narodnu umjetnost u Zagrebu, suradnik dr. Vinka Žganca i analitičar pojedinih Lukićevih rukopisnih zbirki pjesama, a i sam sakupljač šokačkih napjeva, nameće se potreba usporediti i analizirati navedeno sakupljeno blago obaju folklorista.

Analizu korpusa čine Zbirke pismica Slavka Jankovića i Lukićevi dvostisi deseterci objedinjeni u nekoliko rukopisnih zbirki čuvanih u Institutu za etnologiju i folkloristiku te $u$ Muzeju Brodskoga Posavlja. Dio navedene Lukićeve rukopisne građe pjesama nalazi se na Odsjeku za etnologiju u Hrvatskoj akademiji znanosti i umjetnosti. Korpus čini oko 8000 stihova. Analiza neće obuhvaćati stihove koji se ponavljaju, a njih je nekoliko stotina u obojice autora.

Poredbenom su se analizom uočile neke razlike, ali i sličnosti zapisa. Lukićev je rukopis postankom stariji, a obuhvaća deseterce užega Brodskog Posavlja uključujući Oprisavce, Varoš, Kanižu, Klakar, Ruščicu, Trnjanske Kute, Zadubravlje te Gornju i Donju Bebrinu. Janković je opisao i prikupio deseterce iz pojedinih mjesta Slavonije, Baranje i Srijema. I jedan i drugi uz prikupljene deseterce bilježe notno pismo pojedinih dvostiha, mjesto nastanka deseterca te kazivača tog dvostiha. Lukić je precizniji u potonjim podatcima navodeći uz većinu stihova kazivače i mjesto njihova nastanka dok se kod Jankovića ${ }^{36}$ kazivači i mjesto nastanka deseterca ne mogu jasno odrediti. Janković je sve deseterce objedinio terminom pismice, odnosno dvostihovi-deseterci dok ih je Lukić kategorizirao terminom priskočnice ili pjesme.

Iznenađujući rezultat poredbene analize svakako je bilježenje velikoga broja podudarnih stihova Luke Lukića i Slavka Jankovića. Statistička analiza pokazuje da su Jankovićeve zbirke pjesama s Lukićevim rukopisima podudarne u 7,83\% stihova što čini čak 38,07\% Lukićeve cjelokupne rukopisne građe pjesama.

Na osnovu tih podataka moguće je načiniti sljedeće grafove:

\footnotetext{
${ }^{35}$ Podatak je moguće provjeriti u digitalnom repozitoriju Instituta za etnologiju i folkloristiku.

${ }^{36}$ Janković taj nedostatak pojašnjava u uvodu prve zbirke Šokačkih pismica navodeći kako nije znao za to pravilo, ali „,̌im mi je akademik dr. B. Sirola rekao da treba bilježiti ime zapisivača i pjevača, činio sam to dalje svjesno (1967: 28).“
} 


\section{ŠOKAČKI NAPJEVI}

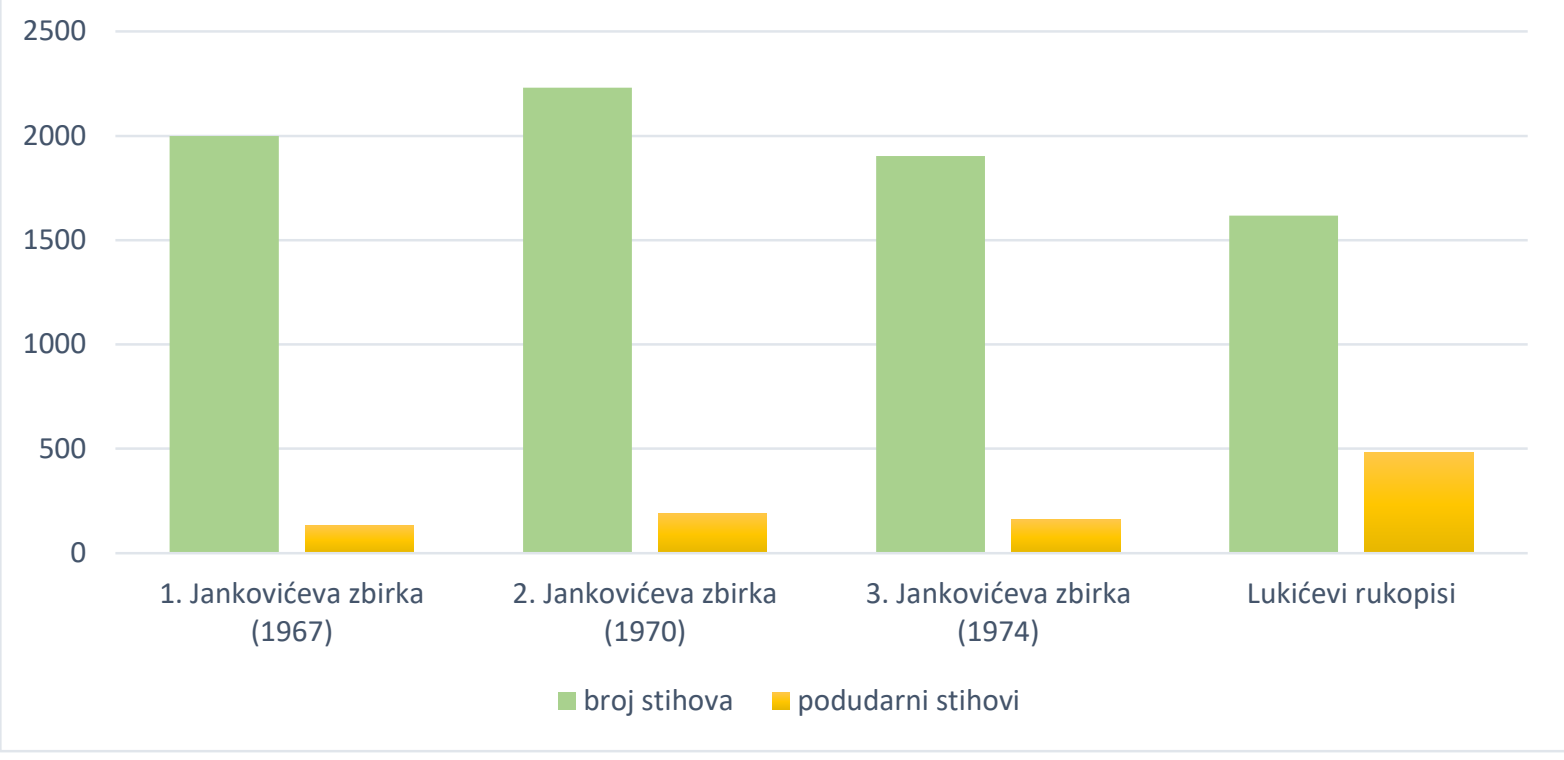

Slika 1. Prikaz podudarnih stihova

Iz grafa (Slika 1) može se iščitati da je u prvoj Jankovićevoj zbirci broj podudarnih Lukićevih stihova 6,60\% (132 podudaranja), u drugoj 8,43\% (188 podudaranja), a u trećoj $8,41 \%$ ili 160 podudarnih stihova.

\section{JANKOVIĆEVE ŠOKAČKE PISMICE}

Udio podudarnih Lukićevih stihova u Jankovićevim zbirkama

$8 \%$

Jankovićeve

zbirke

Slika 2. Udio podudarnih Lukićevih stihova u Jankovićevim zbirkama 


\section{RUKOPISNA GRAĐA LUKE LUKIĆA}

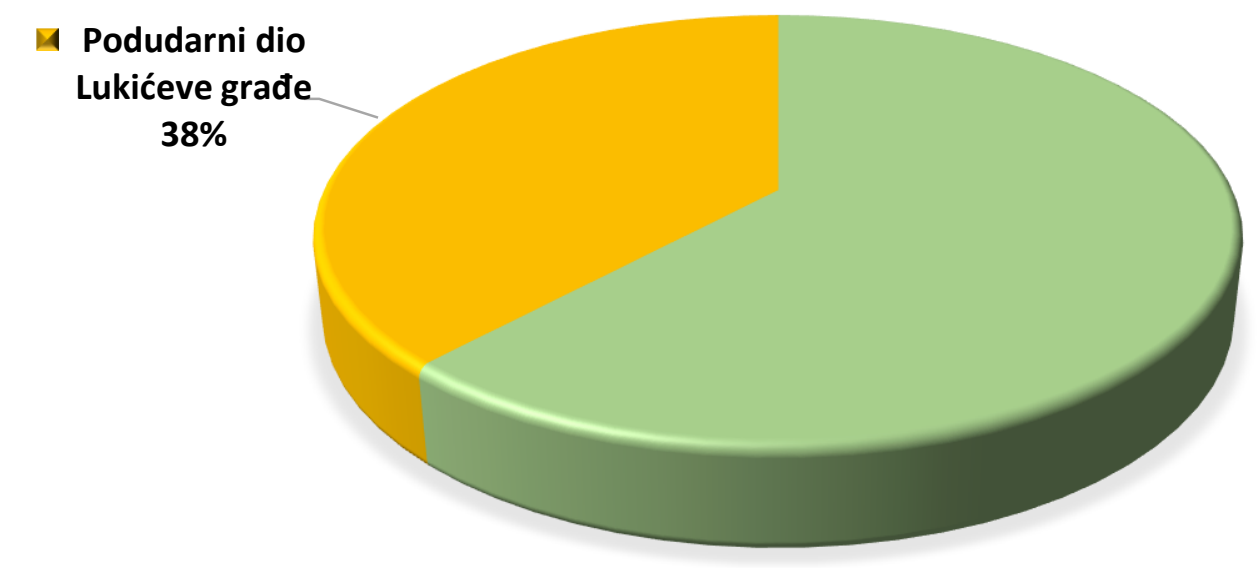

Slika 3. Podudarni dio Lukićeve građe

Gledajući sveukupni broj podudarnih Lukićevih stihova u Jankovićevim zbirkama u odnosu na one u Lukićevoj rukopisnoj građi pjesama, statističkom analizom utvrdilo se 7,83\% podudarnih stihova šokačkih napjeva što pokazuje drugi graf (Slika 2). Podatak se ne čini nevjerojatnim sve dok se ne uzme u obzir sveukupna rukopisna Lukićeva građa pjesama prikazana na trećem grafu (Slika 3) iz kojeg zaključujemo kako je gotovo polovica tih stihova podudarna s Jankovićevim zapisima.

Takve rezultate poredbene analize može se pojasniti činjenicom da lokaliteti na kojima se prikupljala građa nisu toliko udaljeni, da vremenski odmak u kojem se prikupljala navedena građa nije znatan, odnosno da struktura deseterca, čiji se sadržaj oblikuje oko ključnih motiva, a uvjetovan je minimalizmom i rimom, nameće suženi izbor riječi unutar stihova.

Osim identičnih dvostiha, koji čine većinu obrađenih stihova, u korpusu je utvrđen i manji broj dvostiha čija se sličnost očituje u sadržaju, ali je iskazana ili drugim leksemima, sintagmama ili promijenjenim redoslijedom leksema u stihu. Te se stihove može razvrstati u tri skupine (Tablica 1): 1. deseterci s djelomično izmijenjenim prvim stihom, 2. deseterci s djelomično izmijenjenim drugim stihom ili su to 3. deseterci s djelomičnim preinakama obaju stihova, ali iako se izraz promijenio, stihovi su značenjski ostali istovjetni Lukićevim zapisima: 
Tablica 1. Podjela deseteraca

\begin{tabular}{|c|c|}
\hline \multicolumn{2}{|c|}{ Deseterci s djelomično izmijenjenim prvim stihom } \\
\hline Lukićev zapis & Jankovićev zapis \\
\hline $\begin{array}{l}\text { Mene mama i bije i tuče, } \\
\text { al ja idem, kud me srce vuče. } \\
\text { U mene su crne oči male, } \\
\text { i obrazi samo diko pazi. }\end{array}$ & $\begin{array}{l}\text { Mene mama sikiricom tuče, } \\
\text { al ja idem, kud me srce vuče. (3887) } \\
\text { Mene diče obrve i oči, } \\
\text { i obrazi, samo diko pazi. (113) }\end{array}$ \\
\hline $\begin{array}{l}\text { Moje mi se oženilo dere, } \\
\text { i dovelo u selo omelo. }\end{array}$ & $\begin{array}{l}\text { Staro mi se milo oženilo, } \\
\text { i dovelo omelo u selo. }(6080)\end{array}$ \\
\hline $\begin{array}{l}\text { Mene mati i kara i psuje, } \\
\text { za nemilo silom natjeruje. }\end{array}$ & $\begin{array}{l}\text { Za milo me karaju i psuju, } \\
\text { za nemilo silom natjeruju. (3998) }\end{array}$ \\
\hline \multicolumn{2}{|c|}{ Deseterci s djelomično izmijenjenim drugim stihom } \\
\hline Lukićev zapis & Jankovićev zapis \\
\hline $\begin{array}{l}\text { Diko, tijo, ne lupaj s kapijom, } \\
\text { znat' će mama, da ja nisam sama. }\end{array}$ & $\begin{array}{l}\text { Diko tijo, ne lupaj kapijom, } \\
\text { čut će mama, bit ću legedana. (1809) }\end{array}$ \\
\hline $\begin{array}{l}\text { Kiša pada i po malo praši, } \\
\text { moju diku ćeraje perjaši. }\end{array}$ & $\begin{array}{l}\text { Kiša pada i po malo praši, } \\
\text { moga diku prate tamburaši. }\end{array}$ \\
\hline $\begin{array}{l}\text { Nisam cura ko naše divojke, } \\
\text { da se s njima otimam za momke. }\end{array}$ & $\begin{array}{l}\text { Nisam cura ko naše divojke, } \\
\text { da s otimam za šokačke momke. (2404) }\end{array}$ \\
\hline $\begin{array}{l}\text { Ne ljubi se svaku večer dika, } \\
\text { Već se ljubi pete, pa devete. }\end{array}$ & $\begin{array}{l}\text { Ne ljubi se dika svaku večer } \\
\text { petu, šestu osmu i devetu. (1970) }\end{array}$ \\
\hline \multicolumn{2}{|c|}{ Deseterci s djelomičnim izmjenama obaju stihova } \\
\hline Lukićev zapis & Jankovićev zapis \\
\hline $\begin{array}{l}\text { Ljubim malo, pa mi dodijalo, } \\
\text { čuješ diko, tražit ću veliko. }\end{array}$ & $\begin{array}{l}\text { Ljubim malo, već mi dodijalo! } \\
\text { Sad ću diko liubiti veliko. }(5146)\end{array}$ \\
\hline $\begin{array}{l}\text { Ljubilo se dvoje ljubitelja, } \\
\text { bilo b' bolje, da ni roditelja. }\end{array}$ & $\begin{array}{l}\text { Volili se dvoje volitelja, } \\
\text { ljubil' b' se, da nije roditelja. (3985) }\end{array}$ \\
\hline $\begin{array}{l}\text { U Varošu, ko u malom Вес̌u, } \\
\text { pokraj njega ajzibani zveču. }\end{array}$ & $\begin{array}{l}\text { Oj Vinkovci selo ko и Вес̌u, } \\
\text { Ispod tebe ajzibani zveču. (2877) }\end{array}$ \\
\hline $\begin{array}{l}\text { Da je meni diku ljubit kana, } \\
\text { ne bi meni zabranila mama }\end{array}$ & $\begin{array}{l}\text { Da je moja i dikina kana, } \\
\text { ne bi nama zabranila mama. (3783) }\end{array}$ \\
\hline
\end{tabular}


Poredbena analiza podudarnih stihova obuhvaćat će pravopisne značajke s osvrtom na pisanje grafema i digrafa te na bilježenje pojedinih rečeničnih i pravopisnih znakova. Nadalje, poredbenom analizom propitat će se i gramatičke značajke s naglaskom na pojedinim glasovima, glasovnim promjenama i na inačicama u poredbenim stihovima unutar fonoloških značajki te padeži u sklopu morfoloških značajki. Sufiksalna, prefiksalna i mocijska tvorba kao i srastanje bit će dio cjeline rječotvornih značajki, a analizu će se zaokružiti obradom sintaktičkih značajki. Unutar opisa leksičkih značajki donose se samo opći podatci o značenjskim podudarnostima preinačenih leksema te nekolicina primjera kojima se potvrđuje njihova postojanost u korpusu.

\subsubsection{Pravopisne značajke}

Jedna od zanimljivih pojava poredbene analize svakako je bilježenje grafema đi digrafa $d j$. Irena Miloš (2016: 41-42) ističe da je grafija u vrijeme zapisivanja Lukićevih distiha bila novija pa su se palatali upisivali kao $l j, n j, \check{c}, \dot{c}, d, d \check{z}$, no ponegdje još Lukić bilježi dvostruko: $d j$ i đ (npr. đavol i djavol). Također u stihovima Lukić bilježi i oblike glagola doći, izaći, proći, prići, poći, unići dvostruko ili čak trostruko (dojdi, dodji, dođi, dodje, dođe, izajdi, izadji, projdem, prodjem, prođem, pridji, priđi, podješ, pođeš, unidji, uniđi) te osim oblika imenica đevojka, đerdan, prijedloga među u stihovima mu se pojavljuje i oblik djevojka, djerdan, medju.

Lukićev zapis

Grlo moje ko u tice sojke,

Nije tako u svake đevojke.

U devojke oko vrata lanci, a u oca truljavi opanci.

Soldačijo, alaj si mi gorka, kod kuće mi žena ko đevojka.

Oj komšijo prva diko moja, Prilaz pridji, u kućar unidji.

Pristalije poljubit starije, al je sladje poljubiti mladje.

Robovat ću, al za kradju neću,
Jankovićev zapis

Grlo moje ko u 'tice šojke, nije tako u svake divojke. (65)

U divojke oko vrata lanci, a u oca traljavi opanci. (3085)

Soldačijo, alaj si mi gorka, kod kuće mi žena k'o divojka. (3477)

Oj komšijo, moja prva diko, prilaz pridi, u kiljer unidi. (2820)

Pristalije poljubit' starije, Al' je slađe poljubiti mlađe. (1541)

Robovat ću, al' za krađu neću, već za lice svoje golubice. (5658) 
već za lice jedne divičice.

Viči lolo, kad podješ u kolo, Janje medno, pa ćemo zajedno.

Vikni, diko, kad na divan pojdeš, janje medno, pa ćemo zajedno. (2546)

Jedva čekam, da subota dodje, Da mi janje dodje na divane.

Jedva čekam da subota dojde,

Da mi lane dojde na divane. (2506)

Iz navedenih primjera nameće se zaključak kako Janković digraf $d j$ u glagolima bilježi na jedan način, oblikom jd (pojdeš, dojde), a u pridjevima i imenicama preoblikuje ga u grafem đ(krađu, slađe, mlađe) dok isti grafem u leksemu djevojka bilježi grafemom $d$ (divojka/e). Samo je jedan primjer stiha u kojem je digraf $d j$ zamijenjen grafemom $d$ (pridi, unidi).

Posebnu su pozornost poredbenom analizom u korpusu pobudili izostavnik, zarez, navodnici, trotočka te upotreba upitnika i uskličnika, odnosno uskličnika s upitnikom. Dosta je primjera u kojima Janković bilježi izostavnik pri stezanju glagola (zameriso - zamiris'o, prošo - proš'o, nastradam-nas'radam), ali i drugih riječi (svejedno - sve'dno, al-al', tice - 'tice, ko $\left.-k^{\prime} O\right)$.

\section{Lukićev zapis}

Pet put osam četrdeset ravno, nisam diku vidila odavno.

Svit govori, bećaru je lako, da je lako, bio b' bećar svatko.

Dojdi diko, kad si reko doći, Nemoj varat', čudesa ću stvarat'.

Vazdan radim i mislim za dragim: 'oće l' moći $\boldsymbol{k}$ meni večeras doći.

U inoće noge pepeljive, nije prala kako je postala.
Jankovićev zapis

Pet put osam četrdeset ravno, nisam vid'la moga dike davno. (3656)

Misli svako, da j' bećaru lako ...

Da je lako, bio b' bećar svako! (5601)

Dojdi diko, kad si rek'o doći, neka varat', čudesa ću stvarat'. (1623)

Cil dan radim $i$ mislim za dragim, 'oće l' moći $\boldsymbol{k}$ men' večeras doći. (578)

$U$ inoče noge pepeljive, nij' $i$ ' prala, kako je postala. (4491)

Janković navodi izostavnik i u primjerima infinitiva bez završnoga i (ašikovat', poljubit', orat', molit' ću i sl.), no postoje i primjeri u kojima ga izostavlja (popucat će, varat, pit ću, izajt ću, ću parat, razgovarat), iako je istovremeno zabilježen u Lukićevim prikupljenim dvostisima (popucat' će, varat', pit' ću, izić' ću, ću parat', razgovarat'), o čemu sam autor progovara: „Apostrof sam bilježio gdjegod manjka kakav suglas ili samoglas. Taj dakle apostrof, što se 
vidi na riječima, nije naglas ni kako bi se moglo misliti, već samo apostrof i ništa više, a to se može vidjeti i iz same riječi (OE HAZU SZ 128a: 4).“

\section{Lukićev zapis}

Crna zemljo, bil' se orat dala, Što te cura suzama zaljala.

Ne meć ruke na moja ramena, Nisam više ja tvoja medena.

Molim Boga, molit ću i Gospu, da mi dika ne ode na vojsku.

Srce moje nožem ću te parat' još ti ne dam 'uljom razgovarat'.

Dojdi diko, kad si reko doći, nemoj varat', jer ćemo se karat.
Jankovićev zapis

Crna zemljo, bi l' se orat' dala, što te dika suzama zaljala? (2020)

Ne meć' ruke na moja ramena, više nisam ja tvoja milena. (4991)

Molim Boga, molit' ću i Gojspu, da mi diku пе иzти и vojsku. (3454)

Srce moje, nožem ću te parat, još ti nedam s gadom razgovarat. (2167)

Diko moja, kad si reko doći, nemoj varat, jer ćemo se karat. (2241)

U bilježenju rečeničnih i pravopisnih znakova uočavaju se i određene Lukićeve omaške u zapisivanju deseteračkih dvostiha. U stihovima se tako nedosljedno zapisuju ili izostavljaju zarezi, bilježi početak drugoga stiha velikim slovom iako je on samo nastavak izrečene misli prethodnoga stiha, odrednice upravnoga govora nisu uvijek ispravno provedene i sl. ${ }^{37}$ dok Janković nastoji to stilski dotjerati. Tako Janković u stihovima zarezom odvaja riječi u vokativu, drugi stih započinje velikim slovom nakon upotrebljene trotočke ili upitnika, a navodnike ne bilježi, osim u dvama primjerima dvostiha u kojima nešto imenuje.

Zanimljivo je napomenuti kako u Lukićevim dvostisima uskličnik nije zabilježen dok ga Janković bilježi u stihovima u kojima na nešto upozorava, nešto posebno ističe ili pak izražava kakvo iznenađenje ili čuđenje. Iznenađenje Jankovićevih tiskanih zapisa svakako je uskličnik s upitnikom.

\section{Lukićev zapis}

'Ajde lolo, da se pomirimo,
Jankovićev zapis

Ajde, diko, da se pomirimo,

\footnotetext{
${ }^{37} \mathrm{O}$ sličnim problemima vezanima uz višak interpunkcije u Lukićevim prikupljenim pripovijetkama, veliko i malo početno slovo, zatipke te ujednačavanje navodnika govori i Miloš (2016: 42).
} 
Nije lipo, da ne govorimo.

Umri ženo, da te više nema, da dovedem seb' drugu iz Sriema.

Misli diko, mislit' ću i sama, što će biti od našega divana.

Vidi diko tu zelenu travu, tako ćeš se i ti zeleniti, kad ja stanem drugoga ljubiti.

Il' umrla, il' ostala živa, kaži diko, da sam tvoja bila, tvoja bila i tebe ljubila.

U Milana srce od ljiljana, I u mene, pa za njime vene.

Procvala se vijolica plava Na pendžeru, ge mi dika spava.

Ja ne nosim kosu ko što nosu Već ja nosim kosu po prkosu.

Sava nosi drvlje i kamenje, $\boldsymbol{A}$ Morava ranjena Stipana.

Visok pendžer, gatre ${ }^{38}$ u popriko, to ti znači: "ne dolazi, diko."

Meni dika iz Rusije piše:

"Golubice, mene zarobiše.

Pita mama: Imaš li milana? Mati moja, to ni briga tvoja, Ti si mati, ti ne moraš znati.

Čim curice gariš obrvice garim garom lolinom cigarom.

Kako ću te poljubit đevojko? Kad ti lice od maljila gorko.

Naša snaša ne zna Očenaša, mladoženja ne zna pozdravljenja.

Sve me selo zove dunja ranka, nitko ne zna, da ne govorimo. (2002)

Umri, ženo, da te više nema, da dovedem curicu iz Srema. (5692)

Misli, diko, mislit' ću i sama, što će biti od naši' divana. (5295)

Vidiš, diko, tu zelenu travu?

Tako ćešs se i ti zeleniti! (2194)

Il' umrla, il' ostala živa, spomen', lolo, da sam tvoja bila. (4853)

U milana srce od ljiljana, i u mene pa za njime vene. (495)

Procvala se ljubičica plava na prozoru, di mi dika spava. (818)

Ja ne nosim kosu kako nosu, već ja nosim kosu po prkosu. (4190)

Sava nosi drvlje i kamenje, a Morava dragana krvava. (3555)

Na pendžeru uzduž šipke priko, to ti znači: ne dolazi, diko! (2393)

Meni dika iz Rusije piše:

Janje moje, mene zarobiše. (3527)

Pita mama, imam li dragana...?

Mamo moja, nije briga tvoja. (3286)

Čim curice gariš obrvice?

Crnim garom, dikinom cigarom. (2918)

Kako ću te poljubit divojko, lice ti je od bilila gorko. (2934)

Naša snaša ne zna „očenaša“, mladoženja ne zna „pozdravljenja“. (6036)

Mene naši zovu „kruška ranka“,

\footnotetext{
${ }^{38}$ Od njem. Gater (gvozdene šipke u rešetki prozora; giter).
} 
samo lola garava ciganka.

Kaže dika, da me ni voljio,

a zašto je često dolazio?

Misliš diko, da moram umreti,

što me nećeš na jesen uzeti.

Oj Ivane iz Ivanovaca, ne pij vina, ne troši novaca. a moj lola „garava ciganka“. (1323)

Kaže dika, da me ni' volio!

Da rad kog je vraga dolazio!? (4912)

Misliš, diko, da ću ja umreti,

što me nećeš na jesen uzeti!? (4983)

Oj Ivane iz Ivanovaca,

ne pij vina, ne troši novaca! (5628)

\subsubsection{Gramatičke značajke}

Usporedbom korpusa izdvojile su se pojedine fonološke, morfološke, rječotvorne i sintaktičke osobitosti govora Slavonije, Baranje i Srijema prema kojima se uočava određena dosljednost Jankovićevih zapisa u istovjetnim Lukićevim stihovima. Analiza donosi bilježenje glasa $h$, odraza jata, glasovnih promjena, padežnih oblika, tvorbenih primjera, red riječi i sl.

\subsubsection{Fonološke značajke}

Uvidom u korpus uočena je određena razlika u bilježenju riječi koje su posljedica određenih glasovnih promjena vremena u kojem su nastale. Primjerice, u Lukićevim stihovima, nije provedena glasovna promjena jednačenja po mjestu tvorbe te tako glas $n$ ispred zvučnoga $b$ ne prelazi u glas $m$ (bonbon) dok se kod Jankovića u takvim primjerima provodi jednačenje (bombon). Svakako je zanimljiv i primjer leksema milost koji se kod Jankovića pojavljuje u obliku milošće kao posljedica jotacije i jednačenja po mjestu tvorbe u konsonantnoj skupini.

Lukićev zapis

Alaj sam se najela bonbona, iz dikini plavi' pantalona.

Diko lolo, zar si kazat moro, da si meni bonbone kupovo.

Mene dika na bonbone miti: „, Golubice, 'oćeš moja biti"?
Jankovićev zapis

\author{
Alaj sam se najela bombona, \\ iz dikini plavi pantalona. (4573) \\ Jao, lolo, zar si kazat moro, \\ da si meni bombone kupovo. (4602) \\ Mene lola bombonima miti: \\ Golubice, 'oćeš moja biti!? (5292)
}


Jabuka se od milosti daje,

a marama tko ima milana.

Oj curice, tebe dika prosi, tebe prosi, meni milost nosi.

"Svekrva mi milosti poslala, u marame jedan dukat mali, a veliki poslala po diki."
Jabuka se od milošće daje, a marama, tko ima dragana. (4522)

Oj inočo, tebe dika prosi, tebe prosi, men' milošće nosi. (4433)

Svekrva mi milošću poslala, u marami pet dukata mali'. (5461)

Nije sporno da je pisanje odraza jata u Jankovićevim zapisima oblikovano na više načina. Iako je izgovor i pisanje dugoga refleksa jata jedno od složenijih pitanja hrvatske ortoepije i ortografije i danas, Janković to pitanje rješava na sljedeći način. Naime, lekseme s dugim odrazom glasa jata iz Lukićeva rukopisa (driemati, diete, brieg, cvieće, liepo, cielo, Sriem) bilježi kao lekseme s kratkim odrazom jata (dremati, dete, breg, cveće, lepo, celo, Srem). I tu nema izuzetaka. S druge strane, lekseme s kratkim odrazom jata (pjevanje, pjevati, zapjevati, vjenčati, vjerovati, sjedati, bjelilo, djetelina, djever, vjetar, mjesec, mjesečina, djevojka, djeteta) bilježi alternantom $i$ (pivanje, pivati, zapivati, vinčati, virovati, sidati, bililo, ditelina, diver, misec, misečina, divojka, diteta). U Jankovićevim zapisima pronađena su samo dva primjera u kojima je leksem pjevam i pjevaj preoblikovan u ekavski refleks (pjevam pjesme - pevam pesme, pjevaj liepo - pevaj lepo). Nekoliko je primjera u kojima je zabilježen ikavski refleks jata (merisavo - mirisavo, đevojka - divojka, zamerisati - zamirisati), a zapisane su i alternacije i/je (umriti - umrjeti), i/ije (bilo - bijelo), odnosno e/ije (ne smeš - ne smiješ).

Dakle, usporedba tekstova pokazuje kako u Jankovićevu korpusu postoje leksemi i ekavskoga, ikavskoga i ijekavskoga govora. S obzirom na lokalitete ${ }^{39}$ s kojih su prikupljeni dvostisi, taj podatak ne čudi.

U tablici (Tablica 2) prikazana je nekolicina primjera:

Tablica 2. Prikaz leksema deseteračkih dvostiha u različitim govorima

\begin{tabular}{|l|l|}
\hline \multicolumn{1}{|c|}{ Lukićev zapis } & \multicolumn{1}{c|}{ Jankovićev zapis } \\
\hline a) ie & e \\
$\begin{array}{l}\text { Štitar selo i Babina Greda } \\
\text { ta dva sela kumpania ciela. }\end{array}$ & $\begin{array}{l}\text { Stitar selo i Babina Greda, } \\
\text { ta dva sela kompanija cela. } \text { (2884) }\end{array}$ \\
\hline
\end{tabular}

\footnotetext{
${ }^{39}$ O lokalitetima prikupljenih pismica vidjeti Janković (1967).
} 


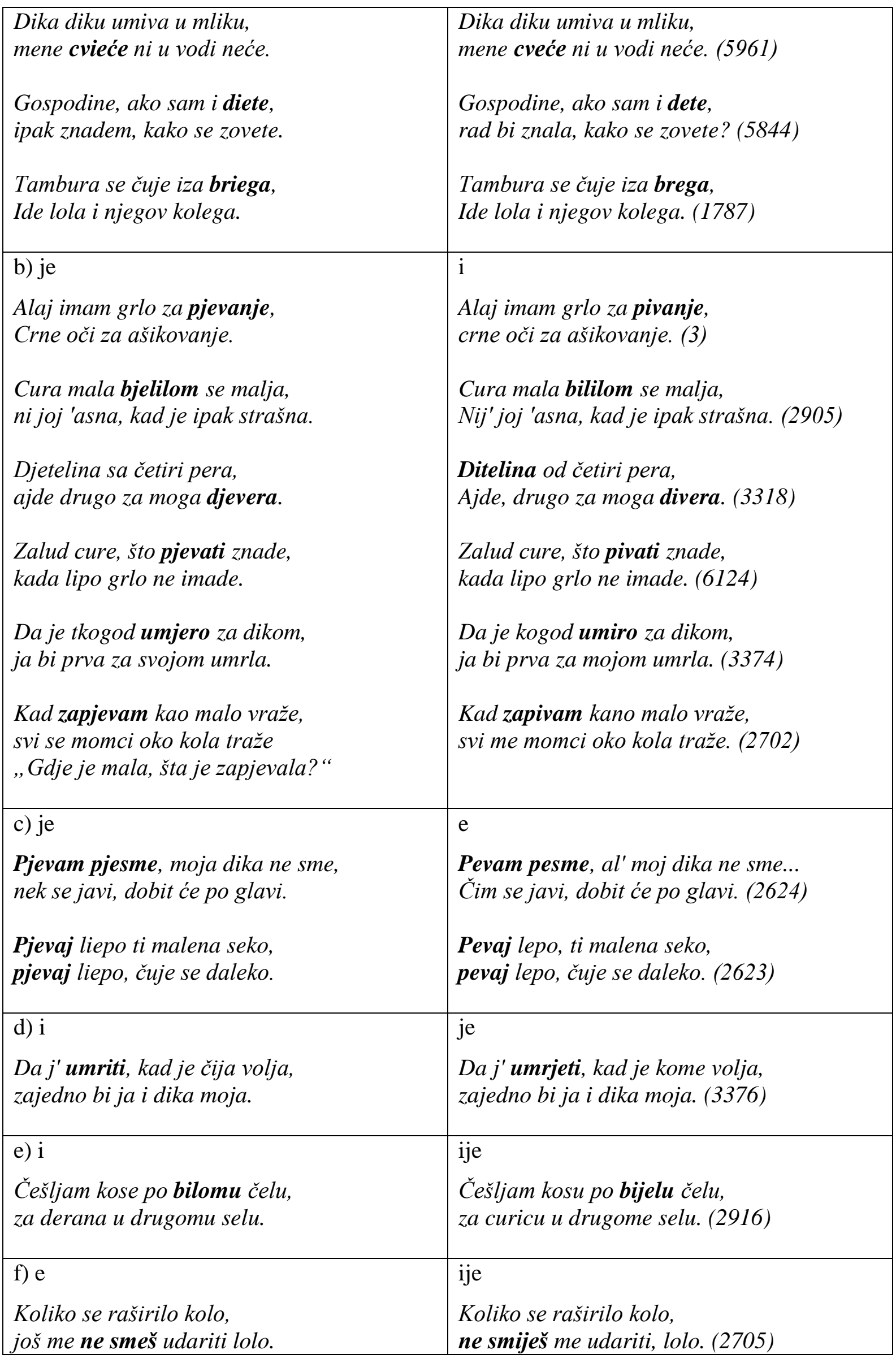




\begin{tabular}{|l|l|}
\hline g) e & \\
$\begin{array}{l}\text { Zvono zvoni, ajziban se krée, }, \\
\text { ode moje merisavo cvieće. }\end{array}$ & $\mathrm{i}$ \\
& $\begin{array}{l}\text { Šinje ječe, ajziban se kré́e, } \\
\text { ode moje mirisavo cveće. (3487) }\end{array}$ \\
\hline
\end{tabular}

Vrlo je zanimljiv ostvaraj glasa $h$ u govorima koje su zabilježili Lukić i Janković. Obojica su se trudila zapisivati onako kako je kazivač govorio, lokalnim idiomom pa sam Lukić (OE HAZU SZ 128a: 19) navodi: „Tako bi znalo biti i kod drugih riječi, gdje se $h$ spominje u književnom govoru, a oni ga nigda i nikako ne izgovaraju.“ Dakle, iako se u starim govorima glas $h$ ne pojavljuje, u Jankovićevim zapisima uočeno je nekoliko rješenja bilježenja toga glasa - izostavnik na mjestu glasa $h$ ili redukcija glasa bez ikakve oznake. Primjerice, dok su kod leksema hlad i hulja uočene dvostrukosti bilježenja izostavnika pa ga Janković na jednom mjestu unutar stiha navodi, a na drugome ne: Vinogradu, moj debeli ladu, Igra kolo u dolu $i$ 'ladu, Curo, 'uljo, ljubio te truljo i Nad bećara gorje ulje nema, u korpusu se pojavljuje nekolicina primjera gdje mu je izostavnik izuzet, a istovremeno zabilježen u Lukićevim primjerima: iz plavi pantalona, ja bi ostavila, asna, ajde.

\section{Lukićev zapis}

Ja sam bećar od maloći male, Pa ću biti dok me ne sarane.

Nema vatre nad rastova panja ni ljubavi prez ašikovanja.

Mila moja ne spremaj darova, nema ništa od naših svatova.

Sanjala sam, ujela me guja, sad je diko od ljubavi uja.
Jankovićev zapis

Bećar jesam od maloće male, pa ću biti, dok me ne sa'rane.

Nema vatre bez 'rastova panja, nit ljubavi bez ašikovanja. (1974)

Mila moja, ne spremaj darova, nema ništa od naši' svatova. (4976)

Sanjala sam, ujela me guja...

Sad je, diko, od ljubavi 'uja. (4736)

Naime, iako zaista mnogo primjera Lukićeva korpusa pokazuje kako se u dvostisima pojavljuju leksemi u kojima nedostaje glas $h$, a istovremeno je ta pojava naznačena izostavnikom, u korpusu se ipak pronalaze i primjeri leksema s tim glasom (hvala, hlad, uhvatiti, hrana, hoće, naših, ih i sl.) kao i oni u kojima je taj glas zamijenjen glasom $k$, v i $j$ 
(muva, kruv, trbuv, snaja i sl.) o čemu piše Miloš (2016: 41) ističući činjenicu kako je „u klakarskom govoru dalje prisutno i svekoliko naglašeno ispadanje vokala i glasa $h$, na čijem se pak mjestu može naći $k, v$ i j.“

U okviru pravopisnih, gramatičkih i leksičkih značajki mogu se uočiti primjeri dvostiha unutar kojih se ističe leksem inoča. Leksem je, unutar fonoloških značajki, izdvojen zbog glasa č. Premda Janković leksem zapisuje navedenim oblikom, Lukić ga u svojim rukopisima beziznimno bilježi glasom ć (U inoće noge ko masuri..., ... u inoće 'iljade na dugu, U inoće, mog čojeka žena... i sl.)

Ljepota govora očituje se i u postojanosti inačica leksema koji čine jezični inventar. Kako se jezik razvija, a unutar njega i pojedini govori, tako se s vremenom oblikuju i stvaraju pojedine inačice. One se razlikuju po obliku, ali istodobno čuvaju zajedničko značenje. Različit oblik inačice, kako je vidljivo u starim govorima Lukićevih i Jankovićevih zapisa, može nastati zamjenom pojedinog glasa/glasova, njegovom/njihovom redukcijom ili joj se dodaje neki sekundarni glas. Prema tome su u zapisima zabilježene sljedeće inačice: masuri-mosuri, gunja

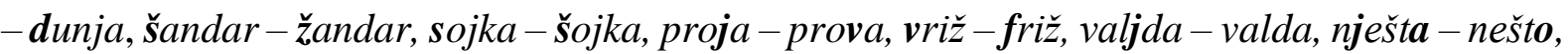
večer - veče, tko - ko, študirat - štundirati, kumpania - kompanija, ganirić - garnerič, hvala -fala, bajdava-zabadava, prez-bez.

Lukićev zapis

Žuta dunja u medu kuvana, ja sam diko drugom obećana.

Mala vrata, a velika brava, 'odaj diko, al' ti je bajdava.

Tko bi mene nadpjevati mogo, taj bi moro študirat mlogo.

Kog ja voljem, i tko mene voli, ljubit' ću ga, ma me noži boli.
Jankovićev zapis

Žuta gunja u medu kuvana, već sam, diko, drugom obećana. (5260)

Mala vrata, al' velika brava, 'odaj, lolo, sve je zabadava. (2392)

Tko bi mene privariti mogo, taj bi moro štundirati mlogo. (2331)

Koga volim i ko mene voli, ljubit ću ga, ma me noži boli. (652) 


\subsubsection{Morfološke značajke}

Slijedom poredbene analize morfoloških značajki u korpusu je uočena i određena različitost u preoblikovanju mjesnoga priloga gdje. Lukić, osim tog oblika priloga, navodi i oblik ge koji Janković gotovo uvijek bilježi oblikom di:

Lukićev zapis

Oj curice, gdje su ti dukati,

što si rekla, da ćeš ih vezati.

Ge si diko već toliko vrime, svi se ljube, a ja nemam s kime.

Udat ću se, ge je dika sama, bit ću gazda od prvoga dana.

Oj bećari, ge su vam 'andžari, što ste lane pripravili za me.

Mjesečina uprla $u$ vrata, Ge me dika grli oko vrata.
Jankovićev zapis

Oj inočo, di su ti dukati, što si rekla, da ćeš povezati. (4376)

Di si diko, za toliko vrime, svi se ljube, a ja nemam s kime. (1742)

Udat ću se, di ću biti sama, bit ću gazda od prvoga dana. (3235)

Oj bećari, di su vam 'andžari, što ste lane naoštrili za me. (5621)

Misečina uprla u vrata, di me dika grli oko vrata. (1512)

U navedenim stihovima pokazalo se kako postoje razlike i u uporabi nekih padežnih oblika unutar stihova. Lukićev je izraz u rukopisima arhaičniji te on bilježi autohtone starije oblike dok je Jankovićev zapis bliži književnom govoru pa umjesto Lukićevih primjera na inoće zvono, na kojoj si strane, ja u sobe, teško trave, u nedilje dana zapisuje na inoči zvono, na kojoj si strani, ja u sobi, teško travi, u nedilju dana i sl.

\section{Lukićev zapis}

Čudo novo, na inoće zvono, da sam rekla, bila bi i klepka.

Golub guče na jelovoj grane, diko moja, na kojoj si strane.

Ja u sobe, dika na ledini, mili Bože, ajde nas sjedini.
Jankovićev zapis

Čudo novo, na inoči zvono...

Da sam rekla, bila bi i klepka. (4245)

Golub guče u šumi na grani:

golubice, na kojoj si strani. (1654)

Ja u sobi, dika na ledini, mili Bože, ajde nas sjedini. (4648) 
Sadi curo drvo jadikovo, pa se jadaj, mene se ne nadaj.
Sadi, lolo, drvo jadikovo, pa se jadaj, meni se ne nadaj. (5030)

Iz korpusa je potrebno izdvojiti i bilježenje glagola u starim govorima. Dok se Lukićeva arhaičnost osjeća i u oblikovanju te vrste riječi, Jankovićevi oblici očekivano su bliži književnome govoru dok su ostali zamijenjeni drugim leksemima. Potonjih je mnogo pa se u tekstu pronalaze sljedeće preinake: upokoji - udovolji, namako - nanizo, zloradi - dosadi, nauživa - naužije, püni-uzmi, osjetile - opazile, odgojila-porodila, laže - kaže, bije - psuje, metala - zatvarala, sakrij-čuvaj, ne pazi - ne slušaj, imam - ljubim, živiti-ladovat, kradem - kartam, naredim - začešljam i sl. Nadalje, u Jankovićevim zapisima Lukićevi oblici glagola voljem, volji, volje, nije voljio, voljemo se, oblik faljio se i umjera, umjero poprimaju oblike volim, voli, vole, nije volio, volimo se, falio se, umire, umiro. Janković ne bilježi uvijek odvojeno negaciju glagola od niječnice ne (nedam, nežuri, neda), a infinitiv glagola doći, izići zapisan je oblikom dojti, izajti. U korpusu interpretiranih deseteraca postoje i primjeri dvostiha u kojima dolazi do promjene kategorije roda glagolskoga pridjeva radnog (si varao - je varalo, nisam znao - nisam znala, nisam vjerovao - nisam vjerovala, bil' ćela - bi 'tio) ili vremena radnje (pucalo je - puknit će, otvorio - otvorite, kupio je - kupuje i sl.).

Lukićev zapis

Alaj voljem, kad zora zaplavi, Kad moj lola lumpuje na Savi.

Vedro nebo i šjeroko polje, al' se, diko, voljemo nas dvoje.

Faljio se jedan od momaka, da j' ljubio devet djevojaka.

Žalost mala kad umjera mama, al velika, kad umjera dika.

Ja i dika molimo se Bogu, Da zajedno trunimo u grobu.

Noge moje sitno koračaje, sva gospoda stala pa gledaje.

Mene ružu, nisam ništa kriva, valjda što sam rumena i bila.
Jankovićev zapis

Alaj volim, kad zora zaplavi, kad moj lola lumpuje na Savi.

Vedro nebo i široko polje, al'se, diko, volimo nas dvoje. (739)

Falio se jedan od momaka, da j' ljubio devet divojaka. (5977)

Žalost mala, kad umire mama, al' velika, kad umire dika. (3390)

Ja i dika molimo se Bogu, da zajedno trunemo u grobu. (887)

Noge moje sitno koračaju, sva gospoda stala pa gledaju. (5872)

Mene ruže, al' ja nisam kriva ... Valjda što sam rumena i bila. (116) 
Devet sati, ide momak curi, ne voli je pa se i ne žuri.

Svadila se ja i moja dika, nećemo se pomirit do vika.

Poručila dika iz Osika,

Da će doći, kad bude sanika.

Moja dika mlogo cura voli, pa mi laže, šta koja govori.

Mene mama u staklo metala, Staklo puče, poljubi me luče.

Crno oko ispalo ti diko, Što si mene varao toliko.

O inoćo, inoćice moja, crkni, pukni, a dika je moja.

Diko moja, kad već skupa nismo, nek te moje upokoji pismo, tebe moje, ko što mene troje.
Sedam sati ide momak curi, ne voli je pa se i nežuri. (1144)

Srdimo se ja i moja dika, ne ćemo se pomirit dovika. (2171)

Poručila dika iz Osika, da će dojti, kad bude sanika. (3473)

Moja dika puno cura voli, pa mi kaže što koja govori. (331)

Mene mama u staklo zatvara, staklo puče, poljubi me luče! (1507)

Crno oko ispalo ti, diko, što je mene varalo toliko! (4674)

Oj inočo, inočice moja, crkni, pukni, bit će dika moja. (4390)

Diko moja, kad zajedno nismo, nek ti moje udovolji pismo. (3598)

\subsubsection{Rječotvorne značajke}

S vremenom u jezičnom sustavu nastane potreba za oblikovanjem novih riječi. Potreba obično nastane radi imenovanja neke nove pojave pa se u tom slučaju pronalaze i novi izrazi ili posuđuju riječi iz drugih jezika pri čemu se one prilagođavaju jeziku primaocu ne samo fonološki i morfološki nego i tvorbeno. Dakle, bilo da pronalaskom ili posuđivanjem riječi nastanu neke nove, ta se jezična pojava zove tvorba riječi. U tom tvorbenom procesu ,riječ koja je polazna ili ishodišna zove se osnovna riječ, a riječ koja tvorbom nastaje zove se tvorenica (Barić i dr. 2005: 285).“ Izvođenje i slaganje osnovni su tvorbeni načini, a unutar njih razlikuje se nekoliko tvorbenih načina: sufiksalna tvorba, prefiksalna, prefiksalno-sufiksalna tvorba, odnosno složeno-nesufiksalna tvorba ili slaganje, složeno-sufiksalna tvorba, srastanje, tvorba složenih skraćenica, preobrazba, analoška tvorba, prevođenje i mocijska tvorba ${ }^{40}$.

\footnotetext{
${ }^{40}$ Više u Barić i dr. (2005).
} 
Analiziranjem Lukićevih i Jankovićevih podudarnih stihova unutar korpusa utvrđeni su leksemi nastali sufiksalnom tvorbom, prefiksalnom tvorbom, srastanjem i mocijskom tvorbom. Unutar sufiksalne tvorbe u Jankovićevim zapisima izdvojile su se uglavnom umanjenice tvorene od imenica ženskoga roda sufiksom -ica (cura - curica, svekrva - svekrvica, soba sobica) te po jedna imenica nastala sufiksom -ina s alternacijom $c / c ̌$ (mjesec - mjesečina) $\mathrm{i}$ jedna imenica nastala od pridjeva sufiksom -uša (garava-garavuša).

U okviru prefiksalne tvorbe istaknuli su se glagoli i prilozi (upopriko - napopriko, odavno-davno) te jedan pridjev (najviše - ponajviše). Od velike većine glagola prefiksacijom tvoreni su svršeni glagoli (ogrli - zagrli, nakiti - zakiti, odabrala - izabrala, uzlopači izopači), ali im se osnovno značenje sačuvalo iako se i ono „modificira s obzirom na način i količinu vršenja, odnosno izvršenosti radnje (nav. dj.: 379)“, no zabilježen je i pâr glagola (posjeći - podsjeći) kod kojeg dolazi do promjene osnovnoga značenja i ono uvelike mijenja i smisao rečenoga u stihu. U stihovima su potvrđeni i primjeri u kojima jedan od glagola nema predmetak, a drugi je rezultat prefiksalne tvorbe (kajala-pokajala, gledala-ugledala, naredaj - redaj).

Kod srastanja, kao tvorbenog načina pri kojem najmanje dvije osnovne riječi srastaju u tvorenicu, zabilježene su sljedeće sraslice: priložne (do vika - dovika, na uvika - nauvika, za badava-zabadava, u veče - uveče, za čudo-začudo, žali bože - žalibože), pridjevne (koje čije - koječije) i prijedložne (na što - našto).

Mocijska tvorba ulazi u sufiksalnu tvorbu, a ona podrazumijeva tvorbu imenica jednoga roda od imenice drugoga roda s razlikom u spolu. U korpusu su se osim takvih mocijskih parnjaka (car - carica, golub - golubica) pojavili i ženski mocijski parnjaci s istim korijenom, ali različitom osnovom (druga od drug - drugarica od drugar) te jedan leksički mocijski parnjak (momci-žene).

Lukićev zapis

Garavušo $^{41}$, šteta što si mala, uzeo bi te na jesen za para.

Ogrli me diko oko struka, nek se tvoja nauživa ruka.
Jankovićev zapis

Oj garava, šteta što si mala, uzeo bi te na jesen za para. (6053)

Zagrli me diko, oko struka, nek se tvoja naužije ruka. (1899)

\footnotetext{
${ }_{41}^{41}$ „Imenice sa sufiksima -ulja i -uša pejorativno su obilježene (Barić i dr. 2005: 312).“U ovom kontekstu garavuša nema pejorativno značenje.
} 
Birtašice naredaj stolice, nek sjedaju lole pijanice.

Lako j' drvo nagnito posjeći, I nemile dike se odreći.

Kad ti stanem prkositi diko pucat će ti srce upopriko.

Sjaj mjeseče, al nemoj u veče, Već u zoru, prati lolu moju.

Drugo moja da si moja mati, kog ja voljem, ne mogu ti dati.
Birtašice, redaj te stolice, nek sidaju lole pijanice. (5537)

Lako j' drvo nagnito podsjeći, i nemile dike se odreći. (1124)

Kad ti pojdem prkositi, diko, pucat će ti srce napopriko. (2089)

Sjaj mjeseče, al' nemoj uveče, već u zoru prati moga lolu. (1883)

Drugarice, da si mila mati, što ja ljubim, ne mogu ti dati. (3322)

\subsubsection{Sintaktičke značajke}

U interpretiranome korpusu Lukićevih i Jankovićevih dvostiha ističu se dva para deseterca s obrnutim redoslijedom stihova, tj. Jankovićev zapis prvoga stiha u Lukićevom rukopisu čini drugi stih i obrnuto. Govoreći o mijenjanju poretka leksema u stihovima, svakako je zanimljivo istaknuti kako se u Jankovićevim zapisima ističe mnogo takvih stihova. Izdvojeni su pojedini, a mijenjanje poretka leksema označeno je polumasnim slovima:

\section{Lukićev zapis}

U subotu, ako bude lipo,

Šala kraju, a ti dojdi diko.

Diko moja ti si bećarina,

Vidi ti se janje na očima.

Al'su žene pizmene na mene, misle lude, da ja voljem ljude.

Cura mala pa bi se udala, al se gadu udati ne dadu.

Plava svila, alaj mi je mila, kupit ću ju, makar uzajmila.

U inoće noge ko dvi tačke, poplašila cilog sela mačke.
Jankovićev zapis

Šala kraju, a ti dojdi, diko, u subotu, ako bude lipo. (2540)

Vidi ti se, diko, po očima, lane moje da si bećarina. (404)

Sve su žene na mene pizmene, misle lude, da ja ljubim ljude. (4126)

Cura mala pa bi se udala, ali gadu udat se ne dadu! (5344)

Alaj mi je plava svila mila kupit ću je, makar uzajmila. (2981)

U inoče noge ko dvi tačke, sve po selu poplašila mačke. (4489) 
Zvoni zvono u Zdravu Mariju, svaka cura u svoju avliju.

Nije dike maramica data, već oteta, bila mu prokleta.

Jao jadna, na što sam navadna, svaku večer, da sam na sokaku, bile ruke na dikinu vratu.
Zvono zvoni na ,zdravu Mariju“, svaka cura u svoju avliju. (5698)

Maramica nije loli data,. već oteta, bila mu prokleta. (4692)

Jao jadna našto sam navadna, večer svaku biti na sokaku. (2503)

Poredbenom analizom utvrđena su i dva stiha u kojima je opažen neobičan poredak riječi. Naime, u Jankovićevim zapisima drugi dio prvoga stiha istovjetan je drugom dijelu drugog stiha Lukićevih zapisa, odnosno drugi dio Jankovićevih dvostiha jednak je drugoj polovici prvog stiha Lukićevih zapisa.

Lukićev zapis

Oj da mi je u nedilje dana, sedam puta viditi milana.

Žen' se diko i ja se udajem, i ja tebi svoj blagoslov dajem.
Jankovićev zapis

$\begin{array}{lll}\text { a } & \text { Oj da mi je viditi milana, } & \text { b } \\ \text { b } & \text { sedam puta u nedilju dana. (814) } & \text { a } \\ \text { c } & \text { Žen'se, diko, blagoslov ti dajem, } & \text { d } \\ \text { d } & \text { žen'se, diko, ija se udajem. (5087) } & \text { c }\end{array}$

Iako su stihovi preinačeni ${ }^{42}$, značenja su im ostala nepromijenjena.

Govoreći o raznim preinakama u tiskanim zapisima dvostiha zanimljivo je još spomenuti i detalj koji se odnosi na kraćenje deseteračkih dvostiha. Naime, rukopise Luke Lukića osim deseteračkih dvostiha čine i deseterci od triju stihova zabilježeni u Jankovićevim zbirkama kao dvostisi. Različite su inačice kraćenja te se tako u Jankovićevim zapisima pronalaze kombinacije prvoga i drugoga stiha, prvoga i trećega stiha, inačica slaganja drugoga

\footnotetext{
${ }^{42}$ Radi lakšega snalaženja opaženih preinaka, u primjerima su završeci stihova naznačeni slovima.
} 
i trećega stiha ili sažimanje dvaju stihova u jedan kao što je prikazano u zadnjem primjeru. Neovisno o kojim se inačicama stihova radi, njihova su značenja također ostala nepromijenjena.

Lukićev zapis

Diko moja nemoj zaostati, ti se ženi, ja ću se udati, pa ćemo se zajedno vjenčati.

Moja mama volje mog milana, oj nevene bolje nego mene, volje zetu nego svom djetetu.

Svi bećari sobe molovali, al ja velim, da svoju obelim, Kad obelim, da u nju preselim.

Jao moji maleni brčići, hoće cura da se s njima diči, Prije reda, ako joj ne treba.

Curo skoči, da ti vidim oči, da ti vidim tvoje oči plave, oče plave, ti moje garave.
Jankovićev zapis

Žen'se diko, ja ću se udati, pa ćemo se zajedno vinčati. (5328)

Moja mama voli mog milana,

Voli zetu, nego svom ditetu. (3271)

Svi bećari sobe molovali, a ja velim, da moju obelim. (5673)

Jao moji maleni brčići, oće cura s nima da se diči. (85)

Curo skoči, da ti vidim oči...

Tvoje plave, a moje garave. (428)

\subsection{Leksik dvostiha i razna leksička rješenja}

Kako je analiza semantičkih odnosa među riječima s naglaskom na sinonimiju, homonimiju i polisemiju glavni dio rada, u ovom se poglavlju donose samo opći podatci o značenjskim podudarnostima preinačenih leksema te nekolicina primjera kojima se potvrđuje njihova postojanost u korpusu. Detaljnija analiza donosi se u posebnome poglavlju.

Naime, poredbena analiza pokazala je da se dijelovi stihova Lukićeva i Jankovićeva korpusa razlikuju i u upotrebi sličnih ili različitih leksema te da njihova uporaba može, ali i ne mora promijeniti kontekst rečenoga. Primjerice, leksemi dika i curica zamijenjeni su u Jankovićevim zapisima leksemima lola i inoča. Sličnih zamjena u Jankovićevim tiskanim zapisima ima zaista mnogo (gumbašica - medaljica, aršin - meter, nevolja - zlotvor, cura dika, sjeroma - matora, janje - lane, janje - diko, kolo - divan, golubica - janje, golub zumbul, sokak - zumbul, fertun - pregač, kućar - kiljer, dunja - kruška, garavo - nemilo, 
medena - milena, lelija - ružica, devet - sedam, zalud - zašto, curica - inoča). U najvećem broju primjera upravo je leksem dika preinačen u leksem lola, ali i obrnuto. Zanimljivo je kako se leksemu bećar kroz stihove pridružuju različite negativne konotacije zamjenjujući ga leksemima bekrija, fakin, švaler, iroš. Samo je u jednom primjeru dvostiha leksem bećar zamijenjen leksemom dragan:

Lukićev zapis

Daleko sam ja od lole svoga, $A l^{\prime}$ je srce jedno kraj drugoga.

Ja i dika mi smo mala roda, pa je nama ašikovat zgoda.

Rodi mama još jednoga sina, pa ćeš imat dva bećara fina.

Visok pendžer, a curica mala, pa ne more viditi bećara.

Žene lajte, dušmani pucajte, a ja mila čija sam i bila.

U djevojke zubi ko lopari, a u mene ko u miša mali.

Curo, 'uljo, ljubio te truljo za iglice i za gumbašice.

Šest aršina Sava je duboka, Sve bi cure za jednoga momka.

Gospodine, piši u novine, Da su seke u Varošu liepe.
Jankovićev zapis

Daleko sam ja od dike moga, al' je srce jedno kraj drugoga. (3583)

Ja i lola maloga smo roda, pa je nama ašikovat' zgoda. (1925)

Rodi, mamo, još jednoga sina, pa ćeš imat dva lipa fakina. (5661)

Visok pendžer, a ja cura mala, pa ne mogu da vidim dragana. (1250)

Keri lajte, dušmani pucajte, a ja mila, čija sam i bila. (4192)

U inoče zubi ko lopari,

a u mene ko u miša mali. (4498)

Curo, 'uljo, ljubio te truljo za iglice i za medaljice. (5947)

Šest meteri Sava je duboka, sve bi cure za jednoga momka. (1104)

Gospodine, piši u novine, da su seke u Vinkovci lepe. (2848)

Leksem dika Janković preinačuje i u lekseme golubica, bećar, janje, lane, cura, a iznenađujući je primjer preinake stiha u kojem je leksem žene zamijenjen leksemom keri. Prethodni su stihovi primjeri u kojima zamjena leksema mijenja kontekst rečenoga. No, u korpusu su zabilježeni i oni primjeri stihova u kojima dolazi do promjene leksema, ali zbog sličnosti njihova izraza, značenje se stihova ne mijenja. Dakle, u stihovima se pojavljuju različiti sinonimični izrazi: imenični (bećarina - pijandura, milutin-dragan, 'ulja-gad, fertun 
- pregač, cika - vika, pendžer - prozor, vijolica - ljubičica, gatre - šipke, bećari-bekrije), glagolski (brani-neda, púni-duni, kaži-spomeni, zaslužio-zavridio, nafarbala-namaljala, ružila - grdila, usanit - uvenit, nemoj - neka, puše - duva, stanem - pojdem, vidit - gledat, poslušaj - čuj, tužit ću - žalit ću, puni-duni, zatamani - pobij), priložni (mlogo - puno, ko što - kako), pridjevski (drago - milo, mlogo - puno), sintagmatski izrazi (popova švalerka parokova seka) i dr. O njima podrobnije u zasebnome poglavlju o sinonimiji.

Uvidom u korpus Lukićevih i Jankovićevih dvostiha poredbena analiza pokazala je zanimljive rezultate. Naime, iako je raščlamba provedena kroz pravopis i gramatiku starih govora te obuhvaća pojedine pravopisne, gramatičke, odnosno fonološke, morfološke, rječotvorne, sintaktičke i leksičke značajke, ne uključuje podrobnije opisivanje tih osobitosti jer to i nije cilj rada, ali je svakako dobar pokazatelj za daljnje proučavanje narodnoga govora unutar zadanoga korpusa. Raščlanjivanjem pojedinih navedenih značajki unutar poredbenih stihova uočene su određene preinake čiji su rezultat ili distinktivni ili identični stihovi. Takvi se rezultati doduše mogu pojasniti činjenicom da lokaliteti na kojima se prikupljala građa nisu toliko udaljeni, da vremenski odmak u kojem se prikupljala navedena građa nije znatan, odnosno da struktura deseterca, čiji se sadržaj oblikuje oko ključnih motiva, a uvjetovan je minimalizmom i rimom, nameće suženi izbor riječi unutar stihova. Je li posrijedi i neki drugi razlog, primjerice prepisivanje dijela građe moglo bi se utvrditi detaljnijom jezičnom 
analizom $^{43}$ i podrobnijim terenskim istraživanjem ${ }^{44}$ iako pouzdanih rezultata da se utvrdi potonje ima kako je pokazala ova poredbena analiza.

\subsection{Zaključne napomene}

Iako se o Slavku Jankoviću, glazbenom entuzijastu, pravniku po struci, pedagogu i promotoru tamburaštva u Hrvatskoj dosta zna, najviše ga se vezuje uz sakupljanje narodnih napjeva, konkretnije šokačkih distiha. Toj je aktivnosti Janković posvetio najveći dio svoga života svjestan ozbiljnosti zanemarenoga narodnog blaga. Prikupljajući građu, pazio je na čuvanje njezine izvornosti te ju je pomno sistematizirao, a rezultat su njegova rada tiskanje samo triju zbirki Šokačkih pismica u kojima je prikupljeno i objavljeno preko 6000 dvostiha. Premda je Jankovićev doprinos etnologiji značajan, iznenađuje činjenica koliko je njegove preostale rukopisne građe ostalo nedovoljno istraženo i neobjavljeno.

Skupljanjem i proučavanjem narodnih napjeva te njihovom sistematizacijom bavio se i Varošanin Luka Lukić. O Luki Lukiću malo je objavljenih podataka. 2016. godine tiskane su

\footnotetext{
${ }^{43}$ Jezik u distisima nije književni, kazivači su dobri ili izvrsni poznavatelji izvornoga govora te je građa uglavnom zapisana na lokalnome jeziku, odnosno narodnome govoru. Govor je Klakara i okolnih mjesta Brodskoga Posavlja ikavskojekavski i pripada štokavskomu narječju. O njegovoj pripadnosti posavskomu poddijalektu arhaičnoga slavonskoga dijalekta više u Jozić (2010), a o nenovoštokavskom arhaičnom šćakavskom dijalektu i o njegovim poddijalektima te sveobuhvatno o slavonskome dijalektu više u Lisac (2003, 2003a). O Leksičkim osobitostima mjesnih govora slavonskoga dijalekta u vinkovačkome kraju više u Petrović (2004), o jezičnim osobitostima baranjskih govora više u Despot (2006), Sekereš (1977), a o govorima u Slavoniji, Baranji i Srijemu više Jakšić $(2003,2015)$. Ovo su samo neki primjerci literature koji mogu poslužiti podrobnijem istraživanju jezične slike deseteračkih dvostiha i razotkrivanju tolike podudarnosti unutar njih samih.

Vuković, Miloš (2015: 73) napominju kako je „narodni jezik koji je Lukić bilježio zapravo jezik koji opisuje Ivšić u Današnjem posavskom govoru. No, Klakar se u Ivšićevu za štokavsko narječje, posebice slavonski dijalekt i posavske govore, važnome radu, spominje samo na nekoliko mjesta, a Lukićev je rukopis nepoznat javnosti pa se o tadašnjemu govoru Klakara danas znade vrlo malo. I od Ivšića dalje o govoru se Klakara također nije pisalo zasebno te ne postoji sveobuhvatniji sintezni pregled jezičnih značajki toga organskog idioma, već se u literaturi donose sporadično podatci iz klakarskoga govora kao oprimjerenja u opisima pojedinih dijalektnih tema koje se tiču posavskoga poddijalekta, posebno fonologije i akcentuacije." Stoga, Vuković i Miloš podrobnije opisuju fonološke, morfološke, sintaktičke i leksičke osobitosti u govoru Klakara analizirajući dio neobjavljenih etnografskih zapisa koji se tiču materijalne kulture i tako doprinose sveobuhvatnoj analizi posavskih govora slavonskoga dijalekta i štokavskoga narječja.

${ }^{44}$ O Lukićevu i Jankovićevu terenskome radu izvijestila je Hadžihusejnović-Valašek (1981: 85) te napominje kako su Lukićeve „notne zapise prepisivali, analizirali i usput komentirali i dr. Vinko Žganec i Stjepan Stepanov i Slavko Janković i Franjo Židovec.“ Posebno je zanimljiv podatak da se „u Zavodu nalazi i drugi dio zbirke Popievke iz okolice Broda (ZIF rkp N42) koji sadržava 28 zapisa. Te Lukićeve melografske zapise iz sela Klakara i Varoši (od br. 51. do 78), analizirao je Slavko Janković uz opaske o načinu izvedbe (nav. dj.: 86).“ Pobuđuje pozornost i činjenica kako se „u Jugoslavenskoj akademiji (ONŽO N25) i Zavodu za istraživanje folklora (ZIF N84) nalazi rukopisna zbirka pod nazivom Luke Lukića: Pjesmarica, koju je S. Janković kompletirao od napjeva II. dijela Lukićeve zbirke (od br. 1 do 82) (nav. dj.: 87).“ Uvidom u spomenute zbirke jasno se uočava velika podudarnost stihova.

Članak također donosi izvore neobjavljene ostavštine Slavka Jankovića.
} 
tri monografije o Luki Lukiću, biografska, etnološka i folkloristička monografija o Klakaru s vrlo obilnom rukopisnom građom. No, golema Lukićeva rukopisna ostavština sustavno uređivana i prikupljana preko pedeset godina, iako povremeno tiskana u časopisu Sveta Cecilija, još je uvijek širokoj javnosti u potpunosti nepoznata. Melografski se zapisi čuvaju na Odsjeku za etnologiju u Hrvatskoj akademiji znanosti i umjetnosti i Institutu za etnologiju i folkloristiku u Zagrebu, no do danas nisu pobudili dublje zanimanje stručnjaka pa zbog toga nisu niti objavljeni, niti sustavno proučeni.

Lukićevi su rukopisni zapisi umjetnička rukotvorina, suvenir prošloga vremena, ogledalo slavonske duše, osjećaja i svijesti jednog naroda kroz koje se ogleda punina života, kulture i običaja selā oko Slavonskoga Broda. Neiscrpan su izvor za daljnja istraživanja kako etnomuzikologiji, etnologiji, a unutar nje folkloristici tako i kulturnoj antropologiji, sociologiji, povijesti, povijesti umjetnosti, filologiji, jezikoslovlju, a i brojnim drugim znanostima.

Zanimanjem za ovu vrijednu građu opravdat će se i Jankovićevo, ali i Lukićevo nastojanje za dokumentiranjem svekolike baštine jednoga kraja te se oteti zaboravu golema ostavština koja je nepravedno godinama zapostavljana. Lukić sam navodi „Naši su Slavonci, a napose naši Posavci, postali od g. 1935. posve zakopčani i nepovredljivi pa se teško, vrlo teško dobije od njih koja pjesma ili arija. “45 Stoga, svaki je dvostih ostavština vrijedna pozornosti.

\footnotetext{
${ }^{45}$ Lukić, OE HAZU NZ 5a: 13.
} 
INSTITUT ZA NARODNU UMJETNOST - ZAGREB

Br. $390 / 37$

\section{ZBIRKA NARODNIH POPJEVAKA $7 / 44$}

$$
\text { Prvi stih popijerke: Bi Itasice; naredaj stolice }
$$

(Posebni naslov):

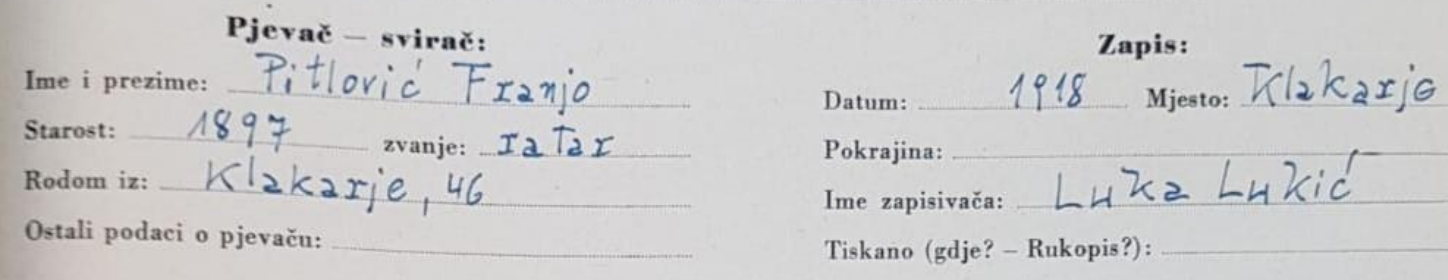

\section{Zivo}

$$
\text { Tempo: 22" }
$$

\section{Napjev:}

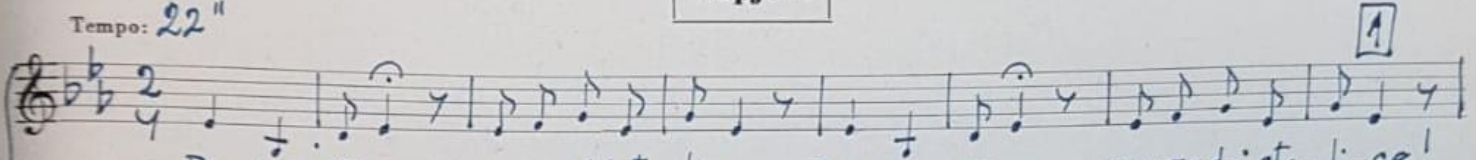

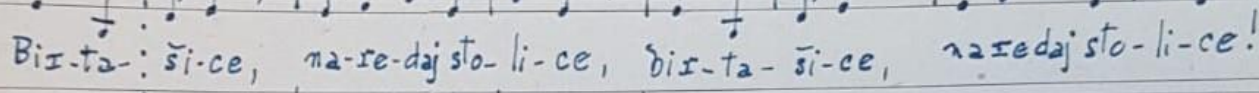

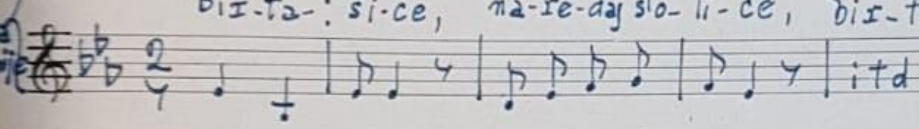
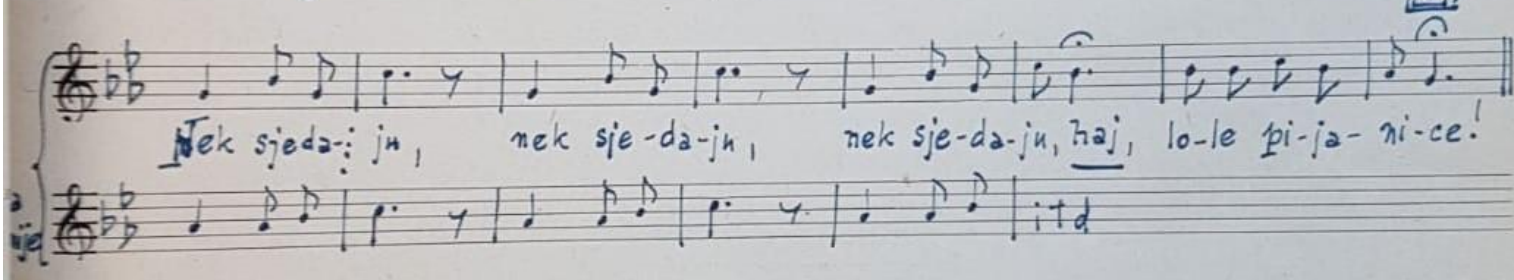

Nota finalis

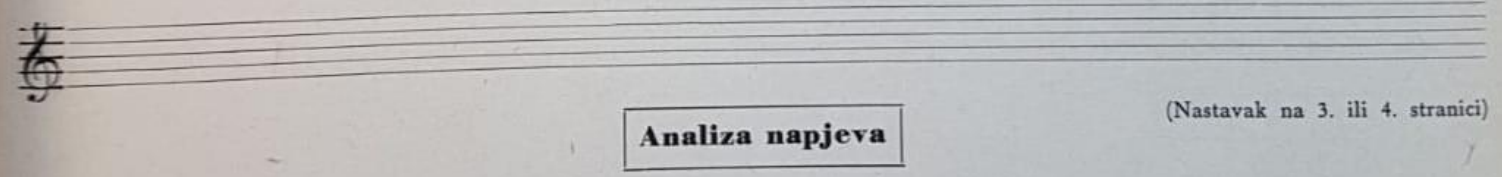

1. Ljestviea:

दी

4. Zavrieci redaka napjeva: $\square$ पा

5. Ritam (i metar):

6. Naročite opaske o napjevu:
2. Opseg napjeva:

3. Struktura (forma) strofe:
7. Komparativna skrižaljka:

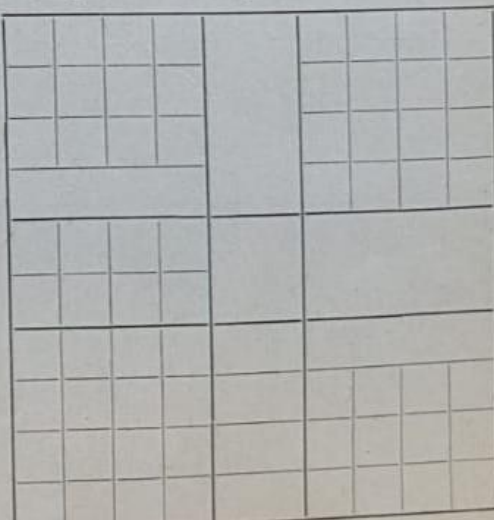




\section{LEKSIČKO-SEMANTIČKI ODNOSI U DVOSTISIMA}

\subsection{Pojam sinonimije i sinonimičnosti}

Sinonimijom se smatra „semantički odnos između dvaju ili više leksema koji pripadaju istoj vrsti riječi i imaju različite izraze“, a s obzirom na podudarnost sadržaja mogu biti potpuni sinonimi ili istoznačnice, odnosno djelomični sinonimi ili bliskoznačnice (Samardžija 1995: 17). Istoznačnicama se sadržaji djelomično ili potpuno podudaraju te mogu zamijeniti jedna drugu u svim kontekstima dok su bliskoznačnice češće u hrvatskome jeziku i ne mogu se zamijeniti u svakome kontekstu jer im se značenja uglavnom podudaraju, no opseg sadržaja nije im jednak. „Dva leksema između čijih sadržaja postoji takav semantički odnos djelomične ili potpune podudarnosti nazivaju se sinonimskim parovima. Kad su u takvu odnosu sadržaji triju ili više leksema, tada je riječ o sinonimskome nizu (Samardžija 1995: 14-15).“

Različiti su odnosi recentnih autora prema definiranju sinonimije. Melvinger (1984: 45) definira sinonimiju „kao odnos među sememima koji se uopće ne razlikuju po strukturi svojih komponenata“ te nadalje tvrdi „kako sinonimične riječi u načelu u istome kontekstu mogu zamjenjivati jedna drugu, a da se opće značenje ne promijeni. No, mogućnost je takve zamjene ograničena različitostima među sinonimima koje ne ovise o njihovom denotativnome ${ }^{46}$ značenju.“ Upućuje na ekspresionističke i stilističke razlike među sinonimičnim riječima.

Tafra (2005: 219) smatra kako „sinonimi moraju označavati isti pojam jer su to riječi koje moraju imati isto značenje, tj. one se u jednojezičniku mogu tumačiti jedna drugom, imati istu definiciju, a u dvojezičniku se prevode istim riječima te mogu stupati s istim riječima u antonimne odnose." Napominje kako sinonimima mogu biti samo riječi iz istoga leksičkogramatičkoga i istoga leksičko-semantičkog razreda te naglašava (2005: 216) kako „miješanje sintaktičkoga i semantičkoga plana, predikacijske i nominacijske funkcije jezika, paradigmatike i sintagmatike, općega i pojedinačnoga izaziva zbrku u analizi jezičnih pojava i metodološku nedosljednost“, a da „,sinonimiju treba istraživati u prvome redu kao oblik paradigmatskih odnosa."

Važno je istaknuti kako je u leksičkome sustavu vrlo mali broj riječi koji imaju apsolutno isto značenje. Zgusta (1991: 88-89) kaže da se „,apsolutna identičnost značenja riječi mora odnositi na sve tri komponente značenja: designaciju, konotaciju i područje primjene. No,

\footnotetext{
${ }^{46}$ Denotativno značenje obuhvaća inherentni, direktni sadržaj leksičkoga značenja, tj. ono po čemu se jedan leksem razlikuje od drugoga te kontekstualni, indirektni sadržaj leksičkoga značenja ovisan o kontekstualnim partnerima koje dani leksem dobiva u složenici, sintagmi i rečenici. Više u Melvinger (1984).
} 
ako postoji razlika barem u jednoj od triju navedenih komponenti značenja, određene riječi možemo zvati bliskoznačnicama, bliskosinonimima, a pojavu bliskosinonimijom. “ Zato je istoznačnost specifična u terminološkim sinonimnim parovima ili nizovima jer članovi niza imaju isti značenjski opseg i nisu stilski obilježeni. Petrović (2005: 126) ističe kako u terminologiji unutar sustava jednoga jezika istoznačnost naziva nastaje zbog prisutnosti stranih riječi i domaćih istoznačnica pa se često dogodi da su, u nastojanju pronalaska zamjene za stranu riječ, domaće i strane riječi istoznačni parovi, no kako istoznačnost otežava usvajanje nazivlja i može izazvati i nesporazume, jednoj se riječi obično daje prednost.

Petrović (nav. dj.: 47) definira sinonimiju kao semantičku kategoriju koja se proučava na apstraktnoj, paradigmatskoj razini i tu je riječ o sinonimiji kao pojavi u sustavu te na konkretnoj, sintagmatskoj razini gdje je riječ o sinonimičnosti kao pojavi u kontekstu. Sinonimnost se odnosi na značajku sinonima u sustavu koju sinonimi posjeduju, ali ne mora biti ostvariva u kontekstu. Razlikuje sinonimiju u leksičkome sustavu hrvatskoga jezika i sinonimiju u leksiku hrvatskoga jezika te navodi da parovi kašika/žlica u hrvatskome standardnom leksičkom sustavu nisu sinonimi, a u leksiku hrvatskoga jezika jesu sinonimi. Nadalje autorica (nav. dj.: 127) ističe da je u razlikovanju sinonima važno opisati svako sinonimno polje pomoću metajezika. Navodi (nav. dj.: 127) da se sinonimna polja u sustavu mogu strukturirati trojako, što se i u radu navodi u cijelosti:

1. pojedina polja imaju djelomično razlikovnu strukturu: debeo, tust, gojazan, punašan...

2. druga se polja mogu opisati istom definicijom, a struktura im je utemeljena na jezičnome raslojavanju tako da su neki članovi obilježeni: lud, poremećen, nerazuman, umobolan, udaren, ćaknut...

3. većina sinonimnih polja ima djelomično razlikovnu strukturu i djelomično utemeljenu na jezičnome raslojavanju. Takva se polja mogu provjeriti zamjenjivošću u kontekstu.

Petrović (nav. dj.: 127-128) razlikovnost među sinonimima u hrvatskome standardnom jeziku svodi na nekoliko kategorija:

1. jedan od sinonima ima opće značenje, a drugi ima specificirano značenje

2. jedan od sinonima ima širu ekstenziju 
3. jedan je od sinonima funkcionalno stilski obilježen, i iako bi se vremenska i područna obilježenost trebale izuzeti, uporaba sinonima u leksičkome sustavu hrvatskoga jezika pokazuje suprotno, kao i uporaba sinonima u kontekstu

4. jedan od sinonima pripada stručnome, a drugi općeuporabnome leksiku.

\subsection{Nastanak sinonima}

Sinonimija se može pojaviti na svim jezičnim razinama, kako u leksičkoj tako i u gramatičkoj, tvorbenoj, sintaktičkoj i sl.

Naime, više je načina na koji nastaju sinonimi. Sistematičan prikaz daje Tafra (2005: 220) pa se on prenosi u cijelosti:

A. Sinonimi nastaju kao rezultat dodira među jezicima

Posuđenica i domaća riječ referiraju na isti referent. Pritom su moguća dva procesa:

a) Posuđenica ulazi u leksik iako postoji domaća riječ za isti pojam (živac, nerv).

b) Ne postoji domaća riječ za neki pojam pa se posuđuje iz drugoga jezika te se nakon usvajanja i prilagođavanja strane riječi naknadno stvara domaća riječ. Tako su nastali sinonimi, primjerice, u informatičkom nazivlju (kompjuter, računalo; ekran, zaslon; internet, međumrežje).

B. Sinonimi nastaju kao rezultat unutarjezičnih procesa

a) tvorbom (slušalac, slušatelj)

b) sinonimizacijom sekundarnih značenja (isplivati /iz dugova/, izići, izvući se (iz dugova/, osloboditi se /dugova/)

c) nominacijom istoga pojma različitim jezičnim znakovima (djelatnik, radnik).

Govoreći o sinonimima unutar leksičko-semantičkih odnosa, najčešće je tumačenje u većine govornika da su to različiti izrazi ista sadržaja, no nisu sve jezične jedinice koje isto znače sinonimi, niti su sve međusobno zamjenjive jezične jedinice u kontekstu sinonimi. Da bi dva različita izraza ista ili slična sadržaja bili sinonimima, moraju ispuniti neke preduvjete. Primjerice trebaju pripadati istom leksičko-gramatičkom i semantičkom razredu, analizirati se unutar istoga idioma, odnosno pripadati istom vremenskom presjeku leksičkoga razvoja. Kada 
su ti uvjeti ispunjeni, može se govoriti o leksičkim sinonimima i sinonimiji, no kada se u suodnos stave posuđenica, strana riječ, arhaizam, dijalektizam, kolokvijalizam, žargonizam, vulgarizam i izvorna hrvatska riječ govori se o sinonimičnim jedinicama jer „sinonimične jedinice u pravilu pripadaju različitim jezičnim podsustavima (Petrović 2005: 180).“ Dakle, treba razlikovati leksičku sinonimiju i sinonime koji se odnose na identičnost riječi u jezičnome sustavu i sinonimičnost kao identičnost koja nastaje u kontekstu.

\subsection{Razdioba sinonima}

Jezikoslovci, ovisno o podudarnosti pojedinih dijelova njihova značenja, sinonime kategoriziraju na različite načine. Iako se, u većine autora, sinonimi dijele na prave i neprave sinonime, potpune i nepotpune, morfološke i leksičke, istoznačnice i bliskoznačnice, potpuniju su razdiobu sinonima predložila dva jezikoslovca: Stjepko Težak (1990) i Marko Samardžija (1995). Mikuć (2018: 3-4) ističe kako „Težak dijeli sinonime u pet skupina. Prvu skupinu čine pravi sinonimi ili istoznačnice. Kao istoznačnice Težak ${ }^{47}$ navodi sljedeće primjere: iako premda, brz - hitar, dobrotvor - dobročinitelj, brinuti se - skrbiti se, drag - mio, krasan divan, kvar - šteta, pijetao - kokot, svršetak - kraj. Drugu skupinu čine sličnoznačnice. Među sličnoznačnicama navodi: psovati-kleti, hladan-studen, lud-bezuman, gaj-dubrava, musti - dojiti. Treću skupinu čine varijantni sinonimi kao što su: zrak - vazduh, nepovrediv neprikosnoven, utjeloviti - ovaplotiti, zanemariti - prenebregnuti. Četvrtoj skupini pripadaju tuđice: naglasak - akcenat, stvaran - realan, stvarati - kreirati. Posljednju skupinu čine tvorbeni sinonimi: gledatelj-gledalac, poštovati-poštivati, komu-kome, lakog - lakoga, čim - čime: oni su normom priznati pa se mogu upotrebljavati u svim stilovima i tekstovima (Težak 1990: 55).“

Petrović (2005: 125) tvrdi da se istoznačnice i sličnoznačnice u toj podjeli nedosljedno razlikuju. Riječi dojiti i musti koje Težak navodi kao primjere ne mogu se smatrati sličnoznačnicama jer imaju različito značenje; dojiti znači 'hraniti mlijekom', a musti 'izvlačiti mlijeko iz vimena'. Naziv tuđice također nije posve primjeren u Težakovoj podjeli jer su tuđice zapravo vrste posuđenica, a primjeri koje navodi pripadaju brojnoj skupini kontaktnih sinonima. Što se tiče zadnje skupine, teško je razlučiti je li u njoj riječ o sinonimima ili o

${ }^{47}$ Težak 1990: 54-55 
varijantama. Prema Petrović, tvorbeni su sinonimi primjeri poput gledalac i gledatelj, dok su lakog i lakoga samo gramatičke varijante, ne i sinonimi.

Bakota (2010: 212) daje Samardžijin prikaz sinonima koje je on opisao prema sljedećim kriterijima:

1. Sinonimi koji su zamjenjivi u nekim kontekstima: smion - hrabar, dovitljiv dosjetljiv, snalažljiv.

2. Sinonimi koji imaju različit opseg sadržaja: put-drum - cesta.

3. Sinonimi od kojih jedan pripada standardu, a drugi područno obilježenome leksiku: hiža (dijalek.) - kuća (knjiž.), snežak (kajk.) - snježić (knjiž.), ftiček (kajk.) - ptičica (knjiž.), megla (kajk.) - magla (knjiž.), protuletje (kajk.) - proljeće (knjiž.).

4. Sinonimi od kojih jedan pripada standardu, a drugi razgovornome jeziku ili žargonu. To znači da se značenje riječi određuje njezinim etiketiranjem, tj. navođenjem sinonima iz drugoga funkcionalnog stila uz preporuku da se kolokvijalni i žargonski član tumači standardnojezičnim sinonimskim članom, a ne obrnuto. Na primjer: penzija (kolok.) - mirovina (knjiž.), ucmekati (žarg.) - ubiti (knjiž.), badava (žarg.) - besplatno.

5. Sinonimi od kojih jedan pripada pasivnome leksiku a drugi aktivnome (tzv. vremenska raslojenost leksika). Tu je ponovno riječ o postupku etiketiranja riječi kao zastarjele, arhaične: plam (arh.) - plamen (knjiž.), uboštvo (arh.) - siromaštvo (knjiž.), pir (arh.) - svadba (knjiž.), cjelov (poet. arh.) - poljubac (knjiž.).

Dakle, prema Samardžiji (1995: 15-16) sinonimi se dijele prema zamjenjivosti u kontekstu i prema prepoznatljivosti u kontekstu. Prema zamjenjivosti u kontekstu sinonimi mogu biti istoznačnice i bliskoznačnice, a prema prepoznatljivosti u kontekstu to su općejezični (samostalni) i kontekstualni (individualni), standardnojezični i nestandardnojezični sinonimi.

Tafra (2005: 218) ne podržava ovakvu podjelu jer navodi kako je nemiješanje dijakronije i sinkronije jedan od uvjeta valjana opisa sinonimije, tj. članovi sinonimskoga niza trebaju pripadati jednome jezičnom sustavu u njegovu sinkronijskome presjeku i da riječi iz pasivnoga leksika ne mogu ulaziti u sinonimne odnose sa svojim sinonimima u aktivnome leksiku sve dok ponovno ne ožive. 
Za razliku od Babića (1990: 260) koji istoznačnice i bliskoznačnice smatra sinonimima, doduše pravim sinonimima determinira riječi koje imaju isto značenje i koje su zamjenjive u svim kontekstima, a nepravim onima koje imaju blisko značenje, prema Ćoruši (2012: 14) „Tafra (2005: 222) odbacuje rješenje o pravim i nepravim sinonimima. Ne prihvaća bliskoznačnost kao podvrstu istoznačnosti i isključuje ju iz dijela leksikologije koji se bavi sinonimijom. Taj odnos definira kao hrvatski naziv za paronimiju ${ }^{48} \mathrm{i}$ ističe kako bliskoznačnice nemaju nikakve veze sa sinonimijom za razliku od istoznačnica. Također odbacuje i Silićevo definiranje sličnoznačnica ili suznačnica po kojemu su one riječi koje se mogu zamijeniti u različitim kontekstima.“ Silić (1998: 174) je mišljenja da su „dublete riječi različitoga izraza i istoga sadržaja, sinonimi - riječi različitoga izraza i sličnoga sadržaja, a varijante (inačice) riječi djelomično različitoga izraza i istoga sadržaja.“ Dublete imenuje istoznačnicama, a sinonime sličnoznačnicama ili suznačnicama.

Determinirajući pojam apsolutnih i pravih sinonima ${ }^{49}$, Hudeček, Mihaljević (2008: 168) navode kako se parovi riječi moraju podudarati i po značenju i po uporabi i imati isto denotativno i konotativno značenje te istu i priopćajnu i komunikacijsku vrijednost dok se kod kvazisinonima ili djelomičnih sinonima denotacija ${ }^{50}$ samo djelomično preklapa. Zrinka Jelaska (2007) pak polazi od pretpostavke da dvije leksičke jedinice ne moraju nužno imati posve isto značenje da bi se mogle smatrati sinonimima. One ne moraju imati istu konotaciju i biti zamjenjive u svim kontekstima, već je dovoljno da omogućuju izbor u nekim kontekstima koji neće ni na koji način utjecati na značenje rečenice kao cjeline.

Ćoruša (2012: 4) bilježi zaključak Bernardine Petrović (2005: 129) „kako pojam sinonimije kao istoznačnosti ili bliskoznačnosti, odnosno kao identičnosti ili bliskosti značenja, nedvojbeno ovisi o činjenici hoće li se značenju pristupiti kao krutom, statičnom skupu komponenata ili će se proći od pretpostavke da je značenje prototipno organizirano i da se oblikuje i izgrađuje u kontekstu u dinamičnome procesu. Na te su dvojbe ponuđena tri moguća odgovora: 1. leksem ima jedno, nepromjenjivo značenje, 2. leksem ima neograničen broj značenja i 3. značenja leksema ima onoliko koliko ima mogućih konteksta u kojima se leksem pojavljuje. Odabir prve mogućnosti bi za sinonimiju značio da su sinonimi samo tzv. 'pravi'

\footnotetext{
48 „Paronimija je semantički odnos dviju ili više riječi iste vrste, iste tvorbene porodice, bliska značenja, ali međusobno isključive u istom kontekstu."Više u Tafra (2005: 225).

49 O potpunim i cjelovitim sinonimima više u Lyons (1981) te o cjelovitoj (apsolutnoj), propozicijskoj i bliskoznačnoj sinonimiji u Cruse (1986).

${ }^{50}$ Denotacija u leksičkoj semantici znači osnovni sadržaj riječi, racionalni, za sve članove jedne jezične zajednice nepromjenjivi pojam koji oslikava predmet, pojavu, svojstvo, odnos i kome je u jezičnom sustavu pridružen odgovarajući formativ. Više u Melvinger (1984).
} 
sinonimi, tj. ako je jedan izraz potpuno istoznačan s drugim, trebali bi se zamjenjivati u svim kontekstima. Druga mogućnost ukazuje na to kako za sinonime nije nužno da se dva leksema moraju preklapati u svim svojim značenjima, jer je to moguće samo u posebnim slučajevima 'prave sinonimije'. Leksem koji se u jednom kontekstu može zamijeniti drugim leksemom bez značenjskog pomaka, u drugim kontekstima ne mora imati tu mogućnost jer se tad radi o različitim sememima leksema. Treća mogućnost ukazuje na to da se u tekstu uvijek ostvaruje samo konkretna, o tekstu i o kontekstu ovisna značenjska uporaba. U identičnim rečenicama dvije relevantne jedinice nisu istoznačne ako nisu identične svim sudionicima komunikacije."

Iz navedenoga slijedi kako je potrebno utvrditi jezične okvire u kojima se sinonimija ostvaruje s obzirom na teritorijalnu, stilsku i vremensku raslojenost jezika ne bi li se mogli bilježiti i sinonimski parovi ili nizovi riječi koji pripadaju dijakroniji jer se sa stilističkoga stajališta sinonimiji može pristupiti i kao pojavi teritorijalne i vremenske raslojenosti leksika pa članovi sinonimskoga niza ne moraju pripadati istome jezičnom sustavu u njegovu sinkronijskome presjeku nego mogu pripadati područno i vremensko raslojenome leksiku.

Dakle, ne bi li opis sinonimije bio cjelovit, potrebno je istraživati sinonime na leksičkoj razini, kao parove ili nizove riječi, ali bi više pažnje trebalo obratiti konkretnoj aktualizaciji sinonima u kontekstu što je i cilj rada jer se unutar njega i sinonimija i sinonimičnost mogu preklapati, ali se ne moraju poistovjećivati kao što tvrdi Petrović (2005: 134). Zaključno, treba razlikovati sinonimiju u leksičkome sustavu hrvatskoga jezika i sinonimiju u leksiku hrvatskoga jezika te pokušati determinirati sinonimne parove ili nizove unutar hrvatskoga standardnog leksičkog sustava i one u leksiku hrvatskoga jezika i jasno ih razgraničiti.

\subsection{Sinonimija i sinonimičnost u deseteračkim dvostisima}

Samardžija (1995: 14 -15) sinonimiju kao pojavu u sustavu promatra na paradigmatskoj razini, a sinonimičnost kao pojavu u kontekstu na sintagmatskoj razini. I Petrović (2005: 13) ističe razliku između sinonimije i sinonimičnosti te sinonimiju također razmatra na dvjema razinama, na paradigmatskoj i sintagmatskoj, pravi terminološku razliku te naglašava kako je „na paradigmatskoj razini riječ o sinonimiji kao pojavi u sustavu, a na sintagmatskoj riječ je o sinonimičnosti kao pojavi u kontekstu”. Tafra (2005: 217) navodi da je „u jeziku kao sustavu jezična jedinica leksem pa je sinonimija značenjski odnos istovjetnosti među leksemima. U 
kontekstu sinonimične mogu biti riječi i jedinice veće od riječi (sintagme, frazemi, kolokacijske sveze ....).“

U radu će se, unutar korpusa deseteračkih dvostiha, analizirati potpuni sinonimi, tj. istoznačnice kao i djelomični sinonimi, tj. bliskoznačnice kojima će se u radu pristupiti kao prema sinonimima te će se proučiti leksički sinonimi u sustavu, tzv. sinonimija i oni $u$ kontekstu, tzv. sinonimičnost. Ispitat će se dakle i odnos sinonimičnih leksičkih jedinica na sintagmatskoj razini gdje će u sinonimične odnose ulaziti i jedinice koje ne pripadaju uvijek istome podsustavu te se neće pažnja pridavati tome jesu li sinonimične jedinice obilježene na bilo koji način - stilski, područno ili vremenski.

\subsubsection{Sinonimija u stihovima}

\subsubsection{Istoznačnice}

Ćoruša (2012: 16) ukazuje na činjenicu da je u recentnoj literaturi puno tvrdnji „da potpunih istoznačnica u jeziku nema, odnosno da su u jeziku malobrojne. Naziv istoznačnost $\mathrm{u}$ hrvatskom je jeziku uobičajen za pojavu, a naziv istoznačnice za lekseme koje imaju isto značenje. Takvi bi leksemi trebali biti zamjenjivi u istoj rečenici na način da njihova zamjena ne mijenja obavijesno ustrojstvo rečenice." U Hrvatskom jezičnom savjetniku (Barić 1999: 296) stoji da ,ako u jeziku i postoje dva izraza, najčešće ne znače potpuno isto ili, ako znače, imaju različitu konotaciju ili uporabnu vrijednost. Ako dva izraza imaju isto značenje, i ako se mogu uporabiti u istom značenju u svakome kontekstu, jedan je od njih suvišan u jeziku. Stoga, najčešće ili jedan istoznačni naziv nestane iz jezika, ili se istoznačnim nazivima značenje razjednači, ili pak dobiju drukčiju stilsku vrijednost.“

Naime, istoznačnicama se podrazumijevaju leksemi koji imaju isto osnovno značenje, značenje koje je općeprihvaćeno za sve govornike neke jezične zajednice. Ako jednom pojmu (označeniku) odgovara više izraza (označitelja), ti su izrazi istoznačni (Tafra 1982). Međutim, kako navodi Maradin (2019: 137) ,postavlja se pitanje mogu li dva pojma koja imaju jednako denotativno značenje imati isto tako jednako konotativno značenje, te biti međusobno zamjenjivi u svim kontekstima? Ako takvi sinonimi doista postoje, jesu li onda stilski opravdani sinonimi zapravo neopravdani? Primjerice, Simeon (1969) naglašava da 'potpuno istoznačnih sinonima stvarno nema, jer svaki donosi nijansu: dijalektalnu, profesionalnu, stilističku, itd., u 
svakom se otkrivaju drugačije namjere govornika u onome što je i kako htio iskazati. O pravim sinonimima moglo bi se možda govoriti u nekim profesionalnim terminologijama"”.

Iako su u pravilu istoznačnice jako rijetke, u terminološkim je „,sinonimnim nizovima istoznačnost specifična (Petrović 2005: 127).“ Ta istoznačnost nastaje zbog prisutnosti stranih riječi i domaćih istoznačnica pa se često dogodi da su, u nastojanju pronalaska zamjene za stranu riječ, domaće i strane riječi istoznačni parovi. Nadalje, domaće istoznačnice nastaju iz više razloga kako navodi Petrović (nav. dj.: 127): ,a) kada se za isti pojam pojave dva različita naziva, b) domaće istoznačnice mogu postati različitim tvorbenim postupcima, c) navođenje istovrijednih ali različitih svojstava u nazivu, d) dodavanjem različitih sufikasa na istu osnovu i e) preuzimanjem ili prevođenjem naziva iz nekoliko jezika.“

S obzirom na brojna stajališta o apsolutnim sinonimima, odnosno istoznačnicama, još uvijek nije zauzeto jedinstveno stajalište niti dan zadovoljavajući odgovor na tu pojavu.

\subsection{Istoznačnice u Jankovićevim zbirkama i Lukićevim zapisima}

Analiza korpusa obuhvaća lekseme deseteračkih dvostiha prve polovice 20. stoljeća, tj. lekseme lokalnoga jezika, odnosno narodnoga govora pa se i u tom obliku bilježe. Iako je Rječnik sinonima hrvatskoga jezika Ljiljane Šarić i Wiebke Wittschen svojim pozamašnim izborom natuknica zamišljen kao praktični rječnik, u svrhu ove analize neće predstavljati temeljnu okosnicu jer je ograničen na „frekventniju građu, uglavnom na aktivan jezični fond“ te će se dogoditi da se u sinonimnom ili sinonimičnom paru nađu i leksemi koji nisu zabilježeni u tom Rječniku. Anićev Veliki rječnik hrvatskoga jezika poslužit će u svrhu definiranja pojedinih leksema.

Prvi dio analize temelji se na istoznačnicama pojedinačnih Jankovićevih i Lukićevih zapisa, tj. leksemima iz istoga leksičko-gramatičkoga i istoga leksičko-semantičkog razreda, a drugi se dio odnosi na lekseme podudarnih stihova dvojice autora. U podudarnim su stihovima zabilježene i određene preinake leksema, ali zbog sličnosti njihova izraza, zapaženo je kako je značenje stihova ostalo nepromijenjeno. Dakle, i u uspoređenim stihovima pojavljuju se različiti sinonimni i sinonimični izrazi. Radi lakše preglednosti uočenih izraza, popis parova sinonima dopunit će se ponekim primjerima dvostiha. 
Uvidom u Jankovićeve zbirke među istoznačnicama utvrđeni su imenični (cika - vika, đavao - vrag, tuga - žalost, stid - sram, mrak - noć), glagolski (ciknuti - vrisnuti, grmjeti pucati, pucati - paliti, kriti - tajiti, svanuti - ogranuti, venuti - sahnuti, uvenuti - usahnuti, kleti - kuniti, umjeti - znati), pridjevski (mirna - spokojna, drag - mio, snen - dremovan, pametna - mudra, raščupana - nepočešljana) te priložni izrazi (nedavno - odskora, mlogo dosta, nedugo - zamalo, kradom - neopazice). U Lukićevim stihovima daleko je manje istoznačnica, no ipak se pojavljuju. To su: glagolski (činiti - raditi, kazati - reći), pridjevski (pametno - mudro, drago - milo) i jedan priložni izraz (puno-dosta).

Jankovićevi zapisi

Lolo moja, đavole i vraže, ko ti moje govore dokaže?

Grmi, puca, nebo zemlju kara, kad se dragi s drugom razgovara.

Lolo moja, bez tebe sam bolna, pokraj tebe mirna i spokojna.

Teret, mamo, al' nije odavno, već odskora napravio lola.
Lukićevi zapisi

Puno činim da ja dike skrivim, što ne radim, da gadu dosadim.

Lako ti je prevariti ludo, al' je teško pametno i mudro.

Ljubila sam i puno i dosta, Al na jednom moje srce osta.

Navedeni primjeri sinonimnih parova redom su prasl. ili prasl. i stsl. porijekla te ih se može ubrojiti u domaće istoznačnice koje supostoje u govoru kao jednakovrijednice.

Istoznačnice su zabilježene i u uspoređenim dvostisima dvojice autora. Najviše ih je glagolskih sinonimnih izraza (tužiti - žaliti, zatamaniti - pobijati, ružiti - grditi, zaslužiti zavriditi, usaniti - uveniti, kazati - spomeniti, braniti - ne dati, liti-teći, biti-tući), nekoliko imeničnih ('ulja - gad, cika - vika, sjena - hlad), pridjevskih (drago - milo, mlogo - puno), priložnih (puno - mlogo, skupa - zajedno) te jedan veznički par sinonima (ko što - kako). Poredbena analiza pokazala je kako su navedeni sinonimi zamjenjivi u dvostisima te kako se promjenom sinonimnog izraza ne mijenja obavijesno ustrojstvo dvostiha što pokazuju i zabilježeni stihovi: 
Jankovićevi zapisi

Grdila me moga dike mama, pa se potljam pokajala sama.

Srce moje, nožem ću te parat, još ti nedam s gadom razgovarat.

Moja dika puno cura voli, pa mi kaže što koja govori.

Jao moja kecelja s garnirom, puno svita gine mi za tilom.

Ja ne nosim kosu kako nosu, već ja nosim kosu po prkosu.
Lukićevi zapisi

\section{Ružila me moje dike mama, pa se potlje kajala i sama.}

Srce moje nožem ću te parat' još ti ne dam 'uljom razgovarat'.

Moja dika mlogo cura voli, pa mi laže, šta koja govori.

Imam suknju sa jednim garnirom, mlogo svita gini mi za tilom.

Ja ne nosim kosu ko što nosu

Već ja nosim kosu po prkosu.

\subsubsection{Bliskoznačnice}

Kako postoje prijepori oko definiranja istoznačnica ${ }^{51}$ tako i termin bliskoznačnost $\mathrm{u}$ jezikoslovlju nije jednoznačan. Tafra (2015: 225) navodi da je u hrvatskom jezikoslovlju odavno (Babić 1966) usvojena podjela sinonima na istoznačnice i bliskoznačnice prema zamjenjivosti u kontekstu. Takva je podjela uobičajena i u svjetskom jezikoslovlju ${ }^{52}$. Bliskoznačnice se, međutim, kod nekih u literaturi smatraju sinonimima, kod nekih ne. Petrović (2005: 125) ističe da „bliskoznačnost obuhvaća tri vrste semantičkih odnosa među leksemima: 1. sinonimičnost među pojedinim značenjima višeznačnica, 2. sinonimičnost među riječima koje nisu zamjenjive u svim kontekstima zbog semantičkih i sintaktičkih zapreka ili zbog različitih konotativnih značenja i 3. sličnost ili bliskost značenja pojedinih riječi“. Prvi i drugi slučaj Tafra (1982) naziva sinonimijom, a treći kvazisinonimijom i naglašava kao se upravo ta pojava u nas smatra bliskoznačnošću. Tafra smatra da sinonimi ne ulaze u sinonimni odnos u

\footnotetext{
${ }^{51}$ O tom problemu Gološ (2017: 48-49) koncizno tumači kako ,jedni ističu mogućnost istog značenja dviju leksema i njihove zamjenjivosti u svim kontekstima, što znači pojavu apsolutnih sinonima (Zgusta 1991, Šipka 1998, Gortan-Premk 2004, Prćić 1997) tipa kuća i dom, murva i dud, harem i groblje, raj i dženet, pendžer i prozor. Za ovaj tip sinonima, u literaturi se koriste i drugi nazivi: potpuni sinonimi (Samardžija 1995), potpuna jednakost (Petrović 2005), istoznačnost (Petrović 2005, Tafra 2005, Šipka 1998) i sl. I dok su pojedini lingvisti kategorični u zastupanju stava o postojanju samo sinonima istoznačnica (Tafra 2005), drugi postavljaju pitanje ima li apsolutnih sinonima i ako ne postoji apsolutna sinonimija, da li se kao glavni razlog nepostojanja može smatrati višeznačnost svake lekseme u jednom jeziku, gdje dolazi i do nepodudaranja u nekim od značenja (Riđanović 1998), dok treći istoznačnost smatraju pravom rijetkošću dajući prednost bliskoznačnicama čije je postojanje opravdanije i poželjnije (Šipka 1998, Petrović 2005). Paralelno su u upotrebi i drugi nazivi za bliskoznačnice: djelomični sinonimi (Samardžija 1995, Riđanović 1998), velika sličnost/bliskost, (Petrović 2005) i sl. Riječ je o leksemama koje su međusobno zamjenjive samo u nekim kontekstima. Zapravo, jedna leksema može biti zamijenjena drugom samo u određenom kontekstu, ali nikako u svim kontekstima jer onda se javljaju ozbiljne posljedice po njeno značenje.“

52 Npr. Zgusta (1971): synonymy i near-synonymy, Murphy (2003): synonymy i similarity.
} 
svom ukupnom ekstenzitetu, već se sinonimni odnosi ostvaruju u pojedinačnim značenjskim nijansama. Nadalje Tafra (2003: 433) ističe da „leksičke jedinice mogu imati bliska značenja ako imaju djelomično podudarne izraze zbog pripadnosti istoj tvorbenoj porodici, dakle, govoreći o bliskoznačnicama ograničava se na istokorijenske leksičke jedinice. Smatra i da su bliskoznačnice leksičke jedinice iz istoga idioma, istoga vremena i istoga leksičko gramatičkoga razreda.“ Tafra (1995) zaključuje da su „,bliskoznačnice riječi koje imaju isto denotativno značenje, ali različitu konotaciju i upotrebu, prema čemu bi riječi koje pripadaju različitim stilovima bile bliskoznačnice.“

Samardžija (1995) je za definiranje bliskoznačnica postavio jasne kriterije. „Ističe da su bliskoznačnice sinonimi koji su zamjenjivi samo u nekim kontekstima, koji imaju različit opseg sadržaja, od kojih jedan pripada standardu, a drugi područno obilježenomu leksiku te od kojih jedan pripada standardu, a drugi razgovornomu jeziku ili žargonu (Samardžija 1995: 15-16).“

\subsection{Bliskoznačnice u Jankovićevim zbirkama i Lukićevim zapisima}

Bliskoznačnica, sinonima bliskoga značenja, zamjenjivih samo u nekim kontekstima $i$ različitoga opsega sadržaja, daleko je više u zapisima Slavka Jankovića i Luke Lukića te ih se, također kao i istoznačnice može svrstati u glagolske (ciknuti - jeknuti, pocikivati - dovikivati, pociknuti-doviknuti, psovati-karati, ginuti-venuti, umrijeti-nemati (koga), ne venuti-ne žutjeti, trunuti - venuti, ogovarati - brbljati, ružiti - govoriti - poručivati, grditi - vikati, lajati - režati, lajati - vikati, pjevati - rožiti, zvoniti - ječati, zapjevati-zaguditi, oženiti se - dovesti si, ženiti se - uzeti se, ženiti se - udavati se, varati-mititi, padati-curiti, padati-slijevati se, zujiti - brujiti, ljubiti - voljeti, ići - kasati, htjeti - kaniti, šarati - varati), imenične (̌̌uša goluša ${ }^{53}$, šiša - goliša, srce - duša, bol - tuga, teret - tuga, kuća - stanje, blago - imanje, kapital - miraz, put - staza, kana - želja, srebro - zlato, doba - vrijeme), pridjevske (jadan tužan, tužna - nevoljna, mili - rođeni, mila - ljubezna, neoženjeno - neudato) i priložne izraze (brez glave - bez pameti, tijo - lagano, tijo - polagano, tijo - polako, tijo - lako, tihano lagano) kojih je najmanje.

\footnotetext{
${ }^{53}$ U Anićevu Rječniku leksem nije uveden u tom obliku, ali bi se mogao dovesti u vezu s leksemom goljo 'onaj koji je gol, koji nema ni da se odjene, puki siromah'.
} 
Jankovićevi zapisi

Oženi se šuša i goluša,

moje lane ne smije od mame.

Ostavit ću i kuću i stanje,

samo neću moje milo janje.

Kad zapivam tijo pa polako, mala usta ne otvaram jako.

Dika će mi ostati brez glave,

bez pameti, kad se mene sjeti.

Diko moja, mila i ljubezna,

kaže mama, da za tebe ne zna.

Ljubi, grli, diko, dok sam voljna, da ne budem tužna i nevoljna.

Svekar laje, a svekrva reži, uzmi lanac, diko, pa i' sveži.

Pada sola, kud ćeš diko moja, s krova curi, $k$ meni se požuri.
Lukićevi zapisi

Oženi se šiša i goliša,

a ne more, tko ne voli ore.

Svud je blato u Klakarju suša, tamo mi je i srce i duša.

Diko tijo, ne lupaj s kapijom, Sam polako, da ne čuje svatko.

Kad zapjevam tijo pa tijano, Čuj me lolo, ja idem lagano.

Ljubi mene neženjeno dere, ja ću tebe zlato neudato.

Umri ženo, da te više nema, da dovedem seb' drugu iz Sriema.

Ni mi žao, što sam uranila, kad sam srela, koga sam voljela, $i$ vidila - koga sam ljubila.

U poredbenim stihovima bliskoznačnica nema mnogo, ali izdvojiti se mogu neki parovi: $k$ večeru - večeras, dražji - slađi, milutin - dragana, milan-dragan, nevolja - zlotvor, stati početi.

Jankovićevi zapisi

Curo moja, spremi se u bilo, večeras ću doći ti zacilo.

Diko moja, moj zumbule plavi, slađi si mi u snu već na javi.

Mili Bože, što zlotvori rade, 'oće mene s dikom da zavade.

Kad ti pojdem prkositi, diko, pucat će ti srce napopriko.

\section{Lukićevi zapisi}

Curo moja, spremi se u bilo, K večeru ću doći ti za cilo.

Diko moja, moj golube mali, Dražji si mi u snu neg' na javi.

Jao jade, što nevolje rade, 'oće mene s dikom da zavade.

Kad ti stanem prkositi diko pucat će ti srce upopriko. 
Navedene su bliskoznačnice većinom višeznačne riječi koje su zamjenjive samo u nekim kontekstima svojim izvedenim značenjima, a neka od njih nisu uvedena u Anićev Veliki rječnik hrvatskoga jezika (dovesti (si koga) 'uzeti koga za ženu ili muža' i sl.).

\subsubsection{Sinonimičnost u stihovima}

Sinonime u leksiku određujemo kao one riječi koje pripadaju istoj vrsti riječi i istome sustavu, odnosno podsustavu. Međutim, što se tiče leksičkih osobitosti sinonimičnih jedinica, u sinonimičnim odnosima mogu supostojati i jedinice koje ne pripadaju uvijek istom podsustavu, primjerice posuđenice, strane riječi, arhaizmi ${ }^{54}$, dijalektizmi, žargonizmi, kolokvijalizmi, vulgarizmi. „Prostorno, vremenski, stilski i socijalno obilježeni leksemi u tekstu mogu biti sinonimičnima (Petrović 2005: 180).“

\subsubsection{Frazemski sinonimi}

Branka Tafra (2005) ,ističe da se frazem ${ }^{55}$ kao višečlani oblik u govoru izražava kao zatvorena, gotova i stabilna cjelina čiji su svi članovi, ili neki od njih, doživjeli semantičku preobrazbu.“ Kao glavne značajke frazema navodi sljedeće: „frazem se kao višečlana jezična jedinica reproducira kao gotova tvorevina; frazemi u pravilu imaju čvrstu strukturu u kojoj su leksičke zamjene ograničene, a gramatičke ne unose značenjske promjene; najmanje jedan član frazema mora imati preneseno značenje; može se aktualizirati u svim sintaktičkim funkcijama u kojima se pojavljuju leksemi - na paradigmatskoj je razini može zamijeniti leksem, a na sintagmatskoj riječ 56 . Frazem izražava jedan sadržaj, jedno značenje, koje može biti isto ili blisko značenju jednoga leksema (Tafra 2005: 216).“

\footnotetext{
${ }^{54}$ Tafra (2005: 218) ističe da ,arhaizmi većinom ne mogu biti u sinonimnom odnosu s nekom standardnom riječi. Razlog tomu je što je za postojanje sinonimije potrebno nemiješanje dijakronije i sinkronije. Važno je da članovi sinonimnoga niza pripadaju jednomu jezičnomu sustavu u njegovu sinkronijskom presjeku." Međutim Petrović (2005: 188) smatra da arhaizmi mogu biti u sinonimnom odnosu s nekom standardnom riječi naglašavajući da „ako jezična jedinica koja se ostvaruje kao arhaizam ima noviji aktualni oblik ili odgovarajuću zamjenu, na sinkronijskoj razini arhaizam i aktualna jezična jedinica mogu biti u sinonimičnome odnosu.“

${ }^{55}$ I oko definiranja frazema postoje brojna razilaženja. Primjerice Jasna Melvinger (1984: 85) frazemima smatra samo one sveze riječi koje se sastoje od najmanje dviju autosemantičkih riječi, Željka Fink-Arsovski (2002: 6) u frazeme ubraja i sveze riječi koje se sastoje od dviju autosemantičkih ili od kombinacije jedne autosemantičke i sinsemantičke riječi. Poput Željke Fink-Arsovski, i Antica Menac (2007: 15) navodi da se frazemom smatra i sveza jedne samostalne i jedne pomoćne riječi.

${ }_{56}$ Ćoruša (2012: 6) ističe kako se „uz pojam riječ veže i pojam leksem koji se obično definira samo kao element na jezičnoj razini, a može se shvatiti kao riječ kodificirana u leksiku. Od pojma leksem širi je pojam leksička jedinica jer su to jezične jedinice koje imaju i plan izraza i plan sadržaja. Stoga leksička jedinica može biti
} 
Tafra tumači kako se „sinonimija u frazeologiji mora proučavati posebno jer su u njoj sasvim drukčiji odnosi s obzirom na to da sastavnice u sintagmi gube svoju samostalnost. Tako nije moguća sinonimna zamjena riječi cigla riječju opeka u frazemu neće ti cigla pasti na glavu, ili plafon i strop u frazemu probiti plafon, ali je moguća zamjena davo i vrag u frazemu idi do vraga/do đavola (2005: 217-218).“ Tafra ovakve leksičke jedinice svrstava u potencijalne sinonime.

Melvinger (1984: 106-107) ističe da ,frazemi mogu ulaziti u odnos sinonimije s riječima (leksičko-frazeološka sinonimija) i s drugim frazemima (frazeološka sinonimija). Sinonimični s riječima mogu biti samo nominacijski frazemi, ali ne svi. Primjerice, za nominacijski frazem kiselo mlijeko u hrvatskome jeziku ne postoji ekvivalentna riječ, ali za frazem pasti u nesvijest postoji ekvivalent i glasi 'onesvijestiti se'. Ponekad frazemi mogu biti ekvivalenti sintagmama, npr. kost $i$ koža 'vrlo mršav'. Frazeološka sinonimija znači podudaranje bitnih semantičkih obilježja dvaju ili više frazema različitoga leksičkog sastava. Osim po leksičkome sastavu, sinonimički se frazemi mogu razlikovati i po sekundarnim semantičkim obilježjima, po stilističkim obilježjima i po sintaktičkoj konstrukciji. To dovodi do nizova sinonimičkih frazema.“

Menac (2007: 72) frazemske sinonime smatra onim frazemima koji ,imaju različit sastav elemenata, ponekad i različitu sliku u svojoj osnovi, a jednako ili blisko značenje. Drugim riječima, da bi dva ili više frazema bili frazemski sinonimi, moraju imati različit leksički sastav uz podudaranje bitnih semantičkih obilježja. U jeziku nastaju iz potrebe da se konstrukcija s oslabljenom, 'izblijedjelom' ekspresivnošću zamijeni novom, čija će ekspresivnost biti svježija, jače izražena.“

\subsection{Frazemski sinonimi u Jankovićevim zbirkama i Lukićevim zapisima}

U korpusu Jankovićevih ${ }^{57}$ i Lukićevih distiha zabilježeno je nekoliko primjera frazemskih sinonima: zlo i naopako, cika i vika, nemati ni stida ni srama, drvlje i kamenje, tuga

jednorječnica (leksem) ili višerječnica (sintagma i frazem), kojoj na planu sadržaja odgovara jedno značenje. Leksičke jedinice shvaćene na takav način elementi su leksičke sinonimičnosti. Bernardina Petrović (2005) riječ definira kao potklasu leksema, podređenicu leksema, jedan oblik leksema koji se realizira kao govorna ili rječnička jedinica, a leksem definira kao ukupnost svih oblika i značenje jedne riječi.“”

${ }^{57} \mathrm{O}$ frazemima u tradicijskim deseteračkim dvostisima u Slavoniji pisao je Ivan Rončević (2019). 
i žalost, leći u zemlju, prolijevati suze, šarati očima, bacati svjetlo te inačica bacati zrake i sl..

U poredbenim tekstovima nisu utvrđeni.

Jankovićevi zapisi

Mila majko, bez tebe je lako, bez dike je zlo i naopako.

Cika, vika, da se ženi dika! ... Daj' moj bio, ne bi se ženio.

Nova mlada samo za tri dana, više nema ni stida ni srama.

Sava nosi drvlje i kamenje, a Morava dragana krvava.

I umret ću i и zemlju leć' ću ${ }^{58}$, koga volim, zaboravit neću.

Plače dika, suza suzu lije, što sam rekla, da za mene nije.

Plače lola i suze proliva, što ne ljubi, u kome uživa.

Gori lampa, lipo svitlo baca, imam diku, umiljat ko maca.

Sunce sija, voli me Ilija, zrake baca, voli me $i$ Aca.

Sunce žeže, vrućina je ljuta ${ }^{59}$, žali mala svojega regruta.
Lukićevi zapisi

Ako lolo ti ostaviš mene, Zaplakat će drvlje i kamenje.

Oj mladosti, velika radosti, a starosti tugo $i$ žalosti.

Pijem, šijem, tjeram do forinte ${ }^{60}$, a kod kuće žena prez obuće.

Diko moja, ne dolazi često, kod mene si izgubio mjesto ${ }^{61}$, nemaš stola, nisi više moja.

Kako je vidljivo iz korpusa, u stihovima se pojavljuju sinonimički odnosi između frazema i riječi (umrijeti - leći u zemlju, plakati - prolijevati suze, liti suze ${ }^{62}$, sijati-bacati $z_{\text {rake }}^{63}$, piti, šiti - tjerati do forinte) te sinonimički odnosi među frazemima (izgubiti mjesto nemati stol(a)). Zanimljivost analize svakako su frazemi unutar čijih se struktura pojavljuju suodnosni sinonimi (zlo i naopako 'veoma loše', cika i vika 'velika galama', nemati ni stida ni

\footnotetext{
${ }^{58}$ Frazem nije zabilježen u Hrvatskom frazeološkom rječniku (2014) - dalje HFR, no zabilježen je još 18. srpnja 1840. kao izraz u pjesmi Pitanje rodoljubca Nikole Boroevića u časopisu Danica ilirska (br. 29, str. 113).

${ }^{59}$ Frazem u značenju 'nesnosna žega, sparina' u HFR-u zabilježen je kao pasja vrućina.

${ }^{60}$ U značenju 'pretjerati do te mjere da se ostane bez ičega'. Frazem nije zabilježen u HFR-u.

${ }^{61}$ 'Izgubiti čiju naklonost, pažnju, zanimanje'. Frazemi (izgubiti mjesto, nemati stol(a)) nisu zabilježeni u HFR-u.

${ }^{62}$ Frazemi u ovim oblicima nisu zabilježeni u HFR-u.

${ }^{63}$ Frazem nije zabilježen u HRF-u.
} 
srama 'ne libiti se ni najgorih djela', tuga i žalost 'jad, bijeda', zaplakat će drvlje i kamenje 'žestoko plakati').

\subsubsection{Sintagmatski sinonimi}

Sintagmatski sinonimi tema su sintaktičke sinonimije koju detaljnije tumači Pranjković (2007: 266) riječima: „Ta mogućnost da se isto ili slično značenje, odnosno funkcija izrazi različitim tipovima gramatičke veze među tagmemima, tj. da se sintagmemi tipa plavooka djevojka mogu zamjenjivati sintagmemima tipa djevojka plavih očiju, jedno je od glavnih izvorišta gramatičke sinonimije na razini sintagmema.“

Bernardina Petrović (2005: 137) određuje sintagme dvočlanim izrazima sastavljenima od dviju punoznačnica, vezanim izrazima koji se kao cjelina razumijevaju i usvajaju, a značenje im je jedinstveno. U pisanome se kontekstu kao sinonimi vrlo često pojavljuju leksem i sintagma (zemljopisna karta - zemljovid), u kontekstu kao sinonimične mogu se pojaviti i dvije sintagme (životno djelo - životno postignuće).

\subsection{Sintagmatski sinonimi u Jankovićevim zbirkama i Lukićevim zapisima}

U analiziranome korpusu zabilježena su dva para sintagmatskih sinonima od kojih je jedan par u odnosu leksem i sintagma (misečina - sjajna zvizda, mama - stara žena). Drugi par sinonima čine sintagmatski izrazi (popova švalerka - parokova seka) utvrđeni u poredbenim tekstovima dvojice autora.

Jankovićevi zapisi

Misečino i ti sjajna zvizdo,

diko moja, zašto si me izdo.

Imam suknju, još da mi je rekla, pa bi bila parokova seka.

\section{Lukićevi zapisi}

Moj se dika dopo mojoj mame, staroj ženi, a ge ne bi meni.

Imam suknju, još da mi je rekla, pa bi bila popova švalerka. 


\subsubsection{Tvorbeni sinonimi}

Petrović (2005: 141-142) navodi kako se u sinonimnim ili sinonimičnim parovima ili nizovima često nalaze leksičke jedinice koje djelomice imaju identičnu tvorbenu osnovu. U ruskome se jezikoslovlju nazivaju istokorijenskim sinonimima, a u njemačkome tvorbenim sinonimima jer su ti sinonimi rezultat tvorbe riječi. Petrović ističe da nasuprot tvorbenim, tzv. istokorijenskim sinonimima stoje leksički, tzv. raznokorijenski sinonimi. Tvorbeni su sinonimi pravilne, sustavne tvorevine za razliku od leksičkih te njihove varijante kao sinonimi konkuriraju samo izvan teksta, rijetko u tekstu; njihov je odnos dan na paradigmatskoj, a rijetko na sintagmatskoj razini. Istokorijenski se sinonimi kod kojih istoznačnost proizlazi iz tvorbenih razloga i kod kojih nema razlike u značenju, trebaju razlikovati od tvorbenih tipova među kojima postoji značenjska razlika.

Stoga, Tafra (2005) kao srodnu pojavu sinonimiji navodi paronimiju i paronime navodeći kriterije koje riječi moraju zadovoljiti da bi mogle biti paronimi. Paronime dijeli u tri skupine: prefiksalne (okopati/opkopati), korijenske (crveniti/crvenjeti) i sufiksalne (označenik/označilac). Utvrđuje „da s obzirom na to da su i paronimi i članovi niza istokorijenskih sinonima međusobno vrlo slični izrazom, razlikuju se s obzirom na značenje; sinonimi imaju isto značenje, a paronimi različito.“ Zaključuje da je ,razlika između sinonima i paronima, osim u tome što se značenjska polja sinonima poklapaju u vrlo velikoj mjeri, a značenjska polja paronima u vrlo maloj, vidljiva također u činjenici da sinonimi mogu činiti sinonimski par ili sinonimski niz dok se paronimi uvijek svode na par jer je njihova zamjenjivost osnovana na pogrešnome izboru jedne od dviju mogućnosti. Zamjenom sinonima $\mathrm{u}$ istom kontekstu značenje se znatnije ne mijenja, a zamjena paronimnih parnjaka rezultira pogrešnim značenjem ili besmislenom porukom.“

\subsection{Tvorbeni sinonimi u Jankovićevim zbirkama i Lukićevim zapisima}

Primjeri tvorbenih sinonima u korpusu Jankovićevih i Lukićevih dvostiha postoje. Utvrđena su tri parnjaka (donositi - raznositi, naučio - izučio, padati-spadati) čija su značenja bliska te se preklapaju, no razlike u značenju ipak postoje: donijeti znači 'prenijeti što od nekud, uručiti komu' dok raznijeti znači 'prenijeti na razne strane', naučiti možemo što te steći kakvo znanje ili vještinu dok izučiti sugerira na postizanje potpunoga znanja. Glagoli padati i spadati označavaju istu radnju 'spustiti se na zemlju'. 
Jankovićevi zapisi

Diko moja, di je kuća tvoja?

laž donaša, pa dalje raznaša.

Tko je mene ljubit naučio, taj je mloge škole izučio.
Lukićevi zapisi

Kiša pada, šljive spadaju,

Crne mi se oče dopadaju.

\subsubsection{Posuđenice}

Posuđenice $^{64}$ su riječi koje su uslijed posuđivanja preuzete iz drugoga jezika (jezik davalac) te su se prilagodile jeziku primaocu. Petrović (2005: 183) tvrdi da je „uporaba posuđenica uz izvorne hrvatske riječi jedna od najčešćih leksičkih osobitosti među sinonimičnim jedinicama u kontekstu. U tome procesu za većinu jezičnih korisnika hrvatskoga jezika važno mjesto zauzimaju internacionalizmi latinskoga ili grčkoga podrijetla. Te se riječi u hrvatskoj jezičnoj uporabi susreću tako često da ih prosječni korisnik jedva još opaža kao strane i bez problema ih može prepoznati izvan konteksta. Takve su riječi (anagram premetaljka, konzumenti - potrošači, balast - opterećenje i dr.) u pravilu sinonimi i izvan konteksta pa se može reći da su i sinonimni i sinonimični.“

Maradin (2019: 141) navodi kako „osim iz kutova strukturalne i kognitivne lingvistike i s deskriptivnoga stajališta te tumačenja u ovisnosti o polisemiji, postoje istraživanja koja sinonimiju promatraju iz kuta kontaktne lingvistike (Nida 1975; Murphy 2003). Dakle, sinonimiji se pristupa i s aspekta jezičnih kontakta. Prema Nidi (1975: 141) odnos između posuđenice i domaće istovrijednice tumači se kao apsolutna sinonimija ${ }^{65}$ pod uvjetom da se zanemari razlika u frekvenciji upotrebe.“ Nadalje bilježi kako Prćić (2005) „u analizi takvih sinonimnih parova ukazuje na složenost sinonimnoga odnosa između posuđenica i domaćih

\footnotetext{
${ }^{64}$ Iako se na standardnojezičnom planu potvrđuju dvije vrste posuđenica - usvojenice kao vrsta posuđenica koje su se potpuno prilagodile normama i funkcijama hrvatskoga standardnoga jezika pa se njihovo strano porijeklo ne prepoznaje i prilagođenice kao vrste posuđenica uklopljenih u hrvatski standardni jezik koje poštuju sve njegove norme, ali se njihovo strano porijeklo još uvijek može uvidjeti, u radu se njihova podjela ne uzima detaljnije u obzir već su obuhvaćene zajedničkim pojmom posuđenice.

65 Ullman (1962) smatra da ne postoje apsolutni sinonimi, već postoje razlike u njihovim određenim komponentama. Zanimljivo je u njegovoj teoriji to što među glavne razloge nastajanju sinonima u engleskome jeziku navodi leksičko posuđivanje, značaj određenih problema u nekom društvu pri čemu se stvara više naziva za isti fenomen (osobito ističe proces metaforizacije) te pomak značenja riječi koji dovodi do promjene u broju sinonima te riječi (usp. Milić, 2013: 33). S druge pak strane Tafra (2005: 230) propituje mogućnost postoje li uopće apsolutni sinonimi, odnosno istoznačnice i upozorava kako još uvijek nije dan jednakovrijedan odgovor na to pitanje.
} 
riječi koje se ne razlikuju samo po frekvenciji upotrebe, već i po nizu drugih obilježja kao što su dodatne implikacije, kolokacijske restrukcije, terminološka i stilska obilježja. Anglicizam koji se udomaći u hrvatskome jeziku počinje razvijati i svoja semantička, sintaktička i kolokacijska svojstva i stupa u nove sinonimne odnose s drugim riječima. Prema tome, sinonimni odnos između anglicizma i domaće istovrijednice kojeg Nida smatra apsolutnim traje zapravo vrlo kratko.“

Tafra (2005: 218) zaključuje kako je „najlakše na primjerima parova domaća riječ posuđenica testirati sinonimnost i sinonimičnost. Hrvatski će lektori printer zamijeniti riječju pisač. I tu neće pogriješiti, ali će pogriješiti ako riječi muzika i kozmos u tekstu bez ikakve dvojbe, kao što redovito čine, zamijene riječima glazba i svemir jer i rječnici tako određuju (usp. ŠRHJ). U većini je slučajeva takva zamjena poželjna jer je riječ o sinonimnim parovima u kojima parnjaci imaju isto značenje pa se preporučuju domaće riječi.“

U svakom slušaju bi se pozajmljivanje ili posuđivanje trebalo shvatiti kao pozitivan proces jer ne znači samo „tek ulazak novih riječi u jezik nego i širenje bogatstva jezika zbog nekih drugih razloga (Grabčanović 2019: 139).“

\subsection{Posuđenice u Jankovićevim zbirkama i Lukićevim zapisima}

Deseterci obiluju posuđenicama ${ }^{66}$ što i ne čudi s obzirom da je područje Slavonije, Baranje i Srijema bilo tijekom duge i bogate povijesti izloženo različitim stranim utjecajima koji su svoje tragove ostavili i u govoru. Dakle, na njega su, uz riječi arapskoga, engleskoga, francuskoga, grčkoga, latinskoga, talijanskoga i mađarskoga podrijetla najviše utjecali daleko brojniji germanizmi i turcizmi s kojima je stanovništvo bilo u izravnome dodiru. Budući da su germanizmi i turcizmi najbrojniji, ne iznenađuje da su u korpusu najviše zabilježeni odnosi domaće riječi i tih posuđenica. Tako se primjerice u pojedinačnim stihovima Slavka Jankovića i Luke Lukića pojavljuju jednaki sinonimični izrazi: imenični (bećar - pijanica, bećar - lola, lola - baraba, bećar - 'ulja, bekrija - lola, lola - pijanac, šatrovac - lola, fakin - lola, lola bitanjga, bećaruša - garavuša, bećaruša - namiguša, milovanje - ašikovanje, cika - galama, vika - galama, kućar - kiljer, bircuz - kavana, larma - vika, lampa - svića, uncut - zlotvor, frajlica - curica, frajla - gospoja, šor - sokak, šor - tratuar), glagolski (govoriti - divaniti,

\footnotetext{
${ }^{66}$ Pojedini parovi sinonima čine leksemi koji pripadaju standardnome obliku, a drugi područno obilježenome leksiku ili razgovornome jeziku.
} 
keriti se - bećariti se, prodati - pazariti, molovati - obijeliti, šetati-špancirati) te pridjevski (fina-ljubezna, adrena- šarena).

Jankovićevi zapisi

Nisam bećar da mi gori svića, već sam lola, lampa gorit mora.

Lolo moja, fina i ljubezna, varaj onog, koji ništa ne zna.

Alaj ću se kerit i bećarit, cile zime. Sam' da imam s kime!
Lukićevi zapisi

Milovanje i ašikovanje,

To mi dvoje dodijat ne more.

Svi bećari sobe molovali, al ja velim, da svoju obelim, Kad obelim, da u nju preselim.

U poredbenim tekstovima dvojice autora manji je broj sinonimičnih izraza, no ipak su zabilježeni najviše imenični (bećar - bekrija, švaler - bećar, bećar - fakin, iroš - bećar, bećarina - pijandura, pendžer - prozor, fertun - pregač, gatre - šipke) te po jedan glagolski (nafarbati - namaljati) i priložni (iroški-bećarski) izraz.

\section{Jankovićevi zapisi}

Pijanduro, tko ti kuću čuva? Vitar duva, pa mi kuću čuva.

Bećar jesam, bećarski se vladam, čudo mi je kako ne nas'radam.

Kaži, curo, koliko si dala, što si svoje lice namaljala.

\section{Lukićevi zapisi}

Bećarino, tko ti kuću čuva? „, Vjetar duva, pa mi kuću čuva.“

Iroš jesam, iroški se vladam, čudo mi je kako ne nastradam.

Kaži mala, koliko si dala?

Dok si svoje lice nafarbala.

U analizi sinonimičnih izraza najviše prevladavaju imenice koje označavaju ženske $i$ muške osobe, apstraktne pojmove te imenice za predmete i mjesta. Glagoli izriču svakodnevnu radnju iz života na selu i gradu te se pojavljuju i nekoliko pridjevskih sinonima i jedan priložni koji se rabe u svakodnevnome govoru. 


\subsubsection{Dijalektizmi}

Iako postoje dvojbe oko definiranja pojma sinonimije između dijalektizama i standardnoga jezika, Tafra (2005: 217) ističe da u okviru dijasistema „riječi iz svih dijalekata mogu ulaziti u međusobne sinonimijske odnose, pa su u tom slučaju pirun i vilica sinonimi, a u rječniku standardnoga jezika nisu." Petrović (2005: 190) smatra da se specifičnost hrvatskoga jezika ogleda upravo u prožimanju standardnojezičnica i dijalektizama ${ }^{67}$, a govornici tu mogućnost, i dijakronijski i sinkronijski uvjetovanu, izražavaju na različite načine i na različitim jezičnim pisanim te u govorenim oblicima. Ako autor teksta zanemari činjenicu da većina čitatelja ne poznaje dijalektalni oblik koji je uporabio u svojem iskazu, mora računati s tim da čitatelj njegovu poruku ili neće razumjeti ili će doći do buke u komunikacijskome kanalu pa će poruka biti krivo interpretirana. Kako bi se izbjegao takav nesporazum, uz dijalektni oblik autor mora uporabiti standardnojezični ekvivalent, tumačenje ili kraću definiciju.

\subsection{Dijalektizmi ${ }^{68}$ u Jankovićevim zbirkama i Lukićevim zapisima}

U korpusu se javlja veliki broj turcizama i germanizama koji pripadaju dijalektalnoj razini. Većina su dijalektizama imenice: bećar - pijanica, bećar - lola, lola - baraba, bećar 'ulja, bekrija - lola, lola - pijanac, šatrovac - lola, fakin - lola, lola - bitanjga, bećaruša garavuša, bećaruša - namiguša, bećar - bekrija, švaler - bećar, bećar - fakin, pustahija obješenjak, iroš - bećar, bećarina-pijandura, pendžer-prozor, fertun-pregač, gatre-šipke, milovanje - ašikovanje, cika - galama, vika-galama, kućar - kiljer, bircuz-kavana, larmavika, lampa - svića, uncut - zlotvor, frajlica - curica, frajla - gospoja, šor - sokak, šor tratuar; nekolicina njih glagoli: govoriti - divaniti, keriti se - bećariti se, prodati-pazariti, molovati - obijeliti, šetati - ̌̌pancirati, nafarbati-namaljati, biti-karati. Sljedeća vrsta riječi prema kriteriju zastupljenosti jesu pridjevi: fina - ljubezna, adrena - šarena te jedan priložni sinonimični izraz: iroški-bećarski.

\footnotetext{
${ }^{67}$ Dijalektizmi se, kao i kolokvijalizmi, žargonizmi, vulgarizmi, eufemizmi i nekrotizmi ubrajaju u kontaktne sinonime koje je Tafra (2005: 216) definirala onima „od kojih jedan leksem pripada hrvatskome standardnom jeziku, a njegov sinonimski parnjak ili drugi članovi sinonimskog niza pripadaju područno obilježenu leksiku, npr. magarac prema osel, tovar i kenjac, perina prema blazina i tuhljica, luk prema kapula, krumpir prema krtola, hladetina prema lučevina ili jastuk prema vanjkuš.“

${ }^{68}$ Pod pojmom dijalektizmi 'izrazi koji pripadaju kojemu od hrvatskih narječja' obuhvatit će se i lokalizmi (izrazi koji pripadaju mjesnom govoru) i regionalizmi (izrazi koji pripadaju cjelinama većim od mjesnih govora) te ih se neće zasebno opisivati.
} 
To su sinonimi koji se koriste u svakodnevnome govoru, i pripadaju domaćem okruženju. Kada su stihovi bili zabilježeni te su dijalektizme uporabljivali i stariji i mlađi govornici jer su bili dio tadašnjega mjesnog govora. Iako se velika većina tih dijalektizama očuvala do današnjih dana u mjesnim govorima u Slavoniji, Baranji i Srijemu, većinu tih sinonimičnih izraza ne poznaju mlađe populacije.

Jankovićevi zapisi

Sjele žene pod dudove grane, pa govore, s kim cure divane.

U mene je pregač s garneričem ... Kažu, diko, da ti se namićem.

Maljaju se požeške frajlice, kako ne bi paurske curice.

\section{Lukićevi zapisi}

Sjerotinjo, šta ću s tobom radit, nit te mogu prodat, nit pazarit.

Fertun plavi s malim ganirićem kažu diko da ti se namićem.

Moja mama moju diku kara, Pusta'ijo i obješenjače, što si moje čedo izujedo?

\subsubsection{Kolokvijalizmi}

Kolokvijalizmi su riječi ili izrazi karakteristični za razgovorni stil, odnosno svakodnevnu, neslužbenu komunikaciju koju, kako tvrdi Petrović (2005: 193), „odlikuje spontanost, neusiljenost, nepripremljenost i prirodnost.“ Iako kolokvijalizmi „čine leksički međusloj između standardnoga jezika i dijalekta (nav. dj.)“ i osobitost su publicističkoga i beletrističkoga stila, uočeni su u velikom broju i u desetercima, tzv. minijaturnim formama koje stvaraju spontani pjevači, a nastaju kao posljedica trenutne događajnosti i stila života. To primjećuje i Botica (1995: 55) ističući da „,narodni život i običaji u raznovrsnim oblicima svoga pojavljivanja ulaze u kratke pjesme, najčešće deseteračke, koje se lako prilagođuju melodiji nekog područja, a društvene se situacije lako opjevavaju, osobito one šaljive, ljubavne, međuljudske i ironične.“

\subsection{Kolokvijalizmi u Jankovićevim zbirkama i Lukićevim zapisima}

Deseterce bi se moglo okarakterizirati kao kratke spontane izričaje određenoga pojedinca koji ih, s obzirom na trenutno raspoloženje i inspiraciju, oblikuju takvima. Upravo 
zbog te karakteristike moguće je opravdati veliki broj razgovornih riječi, odnosno kolokvijalizama u njima, no njihovih sinonimičnih parova nema previše.

U korpusu su utvrđeni sljedeći sinonimični parovi kolokvijalizama: imenični (pop fratar, rod-familija, džemper-vesta, cura-divojka, drugarica-prijateljica, dečko-momak) i glagolski (ječati-drečati, pjevati-oriti, psovati-kuniti, kazati-veliti, puhati-duvati).

Jankovićevi zapisi

Pjevaj, ori, moj dilbere novi, a ti, stari, stani pa uzdani!

Duni vjetre iz priki' sokaka, donesi mi miris od momaka.

Džemper, vesta i strikana rekla, poznam moga lolu izdaleka.

Nisam cura ko naše divojke, da s otimam za šokačke momke.
Lukićevi zapisi

Mene mama i bije i kara,

Što ja voljem pa voljem bećara.

Puni vjetre tijo sa sokaka,

Donesi mi miris od momaka.

Ajde cure od momka do momka, koga nema, onog sam đevojka.

\subsection{Homonimija u deseteračkim dvostisima}

U radu će se unutar deseteračkih dvostiha i na razini leksičko-semantičkih odnosa posebna pozornost posvetiti i odnosima formalne identičnosti među riječima. Nakon različitih pogleda na pojam homonimije i njezinoga terminološkog određivanja u radu će se nastojati dati jasni kriteriji po kojima će se proučavati ta pojava, ali i homofonija, homografija te homoforme te će se upozoriti na male propuste u rječnicima koji su poslužili u ovoj analizi.

\subsubsection{Homonimijska pojmovna i terminološka previranja}

Deseterački dvostisi zanimljivi su i za proučavanje odnosa homonimije, tj. odnosa formalne identičnosti među riječima. Iako ih, s obzirom na brojnost stihova u zadanome korpusu nema puno, ipak su zabilježeni. Naime, poznato je kako pojavi homonimije unutar hrvatskoga jezika ${ }^{69}$ još uvijek nije pridana dovoljna pažnja te time ni ona sama još uvijek nije

\footnotetext{
${ }^{69}$ Branka Tafra (2016: 145-146) i sama progovara o uočenome problemu navodeći kako svrha njezina rada nije vraćanje temi homonimije i njezinoj temeljitoj obradi „nego raspravljanje o tvrdnjama iznesenim u novijoj
} 
jednoznačno definirana ${ }^{70}$ pa je autorima njezina opisa dano dovoljno prostora ne bi li pojavu homonimije dosljednije i sustavnije obradili te svojim istraživanjima pomirili neslaganja među jezikoslovcima.

O neslaganjima je progovorila i Tatjana Dobričević (2000) prikazavši prilično neujednačena stajališta triju jezikoslovaca: Branke Tafre, Marka Samardžije i Danka Šipke. Naime, navedeni se jezikoslovci razlikuju u definiranju homonimije kao sustavne pojave na koju ukazuje Tafra te kao pojave što postoji u sustavu i događa se u realizaciji sustava na što ukazuju Samardžija i Šipka. Iz toga, naravno, proizlaze i različiti pogledi u definiranju homonimnoga odnosa. Tafra kao osnovne uvjete homonimnog odnosa među leksemima navodi njihovu identičnost na planu izraza, tj. pripadnost istome leksičko-gramatičkome razredu te svaku odsutnost semantičke kohezije ${ }^{71}$. Ukratko, da bi dva leksema bila u homonimnome odnosu trebaju pripadati istome gramatičkome razredu i biti izjednačeni u svim oblicima paradigme. Bez iznimaka. S druge strane, Samardžija i Šipka ${ }^{72}$ postavljaju fleksibilnije granice leksičke homonimije te nisu tako izričiti u određivanju njezina opsega. Naime, oni $u$ homonimnome odnosu promatraju samo one oblike koji su realizirani, a ostali im nisu u fokusu interesa $^{73}$. Na temelju izjednačenosti tih oblika utvrđuju kako leksičke jedinice imaju isti plan izraza i smatraju ih homonimima.

kroatističkoj literaturi i osvjetljavanje homonimije u hrvatskom jeziku iz različitih kutova kako bi se dobila jasnija slika o tom leksičkom odnosue".

${ }^{70}$ Ruski lingvist Krongauz (2001: 149) homonimiju određuje „podudaranjem forme (usmene ili pisane) različitih jezičnih znakova, prije svega leksema i oblika riječiec. Uvjetom da su dva leksema homonimna smatra nužnost pripadanja istoj vrsti riječi i podudarnost svih oblika s pripadajućim gramatičkim značajkama, no ne isključuje da su dva leksema homonimna i ako pripadaju različitim vrstama riječi, ali su oni tada nepromjenjivi i treba im se poklapati usmena ili pisana forma.

Simeon (1969: 486) homonimiju određuje pojavom u kojoj „dvije ili više riječi različita značenja i podrijetla imaju isti zvuk ili istu grafiju"e. Za njega homonimija može biti apsolutna ili potpuna te parcijalna ili djelomična te homonimi ne trebaju nužno pripadati istoj vrsti riječi. Više u Simeon (1969).

Čubrić (2005: 42) navodi da su homonimi „riječi koje imaju isti izraz, a različit sadržaje“ što Tafra (2016: 148) osporava jer je uz homonimiju vezano razlikovanje pridjeva isti i jednak. Naime nadalje navodi da ,svaki homonim ima svoj izraz i svoj sadržaj koji su usporedivi s izrazom i sadržajem drugoga homonima. Dakle, dva su leksema izrazno jednaka, a ne ista. ${ }^{. e}$

Melvinger (1984: 38) homonime definira kao „riječi koje imaju iste formative, a posve različita značenja (grč. homonyma od homos - značenje i onyma - ime). “ Prema Melvinger homonimi značenjski najčešće nisu ni u kakvoj svezi. Kod homonimije isti formativ s različitim značenjima pripada različitim leksemima.

${ }^{71}$ Dakle, po Tafri (1986: 385) uvjet za homonimiju kao leksičku pojavu ,jest identičnost zvučnog plašta i gramatičkih formi dvaju ili više leksema i potpuna odvojenost njihovih semantičkih strukturae ${ }^{e}$. Dakle semantička obilježja dvaju ili više leksema nemaju ni jednu dodirnu točku, tj. „,imaju sve jednake lekse i ni jedan integralni semee.

${ }^{72}$ Kod Šipke je jedinstveno to što homonimiju određuje kao jednu od vrsta višeznačnosti, zajedno s polisemijom, heterosemijom i bliskoznačnošću. Veliku pažnju posvećuje leksičkoj homonimiji koju promatra u sustavu (homonimnost), u realizaciji (homonimičnost) i u rječnicima (rječnička homonimija). Razlikuje četiri tipa homonimije: punu homonimiju, homoformiju, homografiju i homotoniju. Više u Šipka (1990).

${ }^{73}$ Više u Dobričević (2000). 
S teorijskoga gledišta kada se govori o homonimiji Rosandić, Silić (1979: 41-44) ističu kao „tzv. sinkretizam ili gramatičku homonimiju o kojoj se govori u okviru morfologije, a koju treba razlikovati od leksičke homonimije. Naime, utvrđuju kako se ,gramatički morfemi često podudaraju u izrazu, ali razilaze u sadržaju kao u primjerima leksema grada, sela, žena itd. Gramatičke morfeme ne smijemo promatrati izvan njihove veze s osnovom jer je gramatički morfem jednoznačan samo u spoju s osnovom grad i tad on znači genitiv jednine muškoga roda, u spoju s osnovom sel i tad on znači genitiv jednine srednjega roda i u spoju s osnovom žen on znači genitiv jednine ženskoga roda. ${ }^{e}$ U primjerima gdje se morfemi pojavljuju u istoj paradigmi, zajedno s jednakom osnovom za otklanjanje nedoumica, tj., za gramatičko određenje potreban je širi kontekst. „Tako se morfem $i$ u leksemu kosti utvrđuje kao morfem i genitiv jednine ženskoga roda u spoju napuklina kosti, kao morfem i dativ jednine ženskoga roda u spoju prići kosti, kao morfem i instrumental jednine ženskoga roda u spoju udariti tvrdom kosti. Općenito se može reći da se morfemi kada je riječ o njihovu podudaranju u izrazu, a nepodudaranju u sadržaju, najlakše utvrđuju u spojevima riječi. ${ }^{e}$

Isti autori govore i o homonimskim morfemima ili morfemskim homonimima ${ }^{74}$, te o njezinoj prisutnosti među prefiksima, korijenima, sufiksima i nastavcima.

O problemu različitog određenja homonimije ukazuju i Hudeček, Mihaljević (2009) navodeći svoja viđenja četiriju uzroka proturječnomu određenju homonimije; postojanje tzv. ljestvične homonimije ${ }^{75}$, nejasno utvrđen odnos između homonima i homoforme ${ }^{76}$, nejasno određenje homonimije samo ako je riječ o istim vrstama riječi i nejasnoća o definiranju homonimije riječi različitoga normativnog statusa ili onih riječi koje pripadaju različitim dijalektima. Smatraju da je neusklađenost definicija homonima u različitome razumijevanju homonima u užem i širem smislu jer Hudeček, Mihaljević (2009: 163) bilježe kako „homonimi u širem smislu obuhvaćaju homografe, homofone, homoforme i prave homonime, tj. homonime u užem smislưe

\footnotetext{
${ }^{74}$ Više u Rosandić i Silić (1979: 69).

${ }^{75}$ Homonimija u užem i širem smislu. Hudeček, Mihaljević (2009: 162) navode kako „u širem smislu homonimija obuhvaća i homofoniju i homografiju i potpunu homonimiju, a u užem smislu samo potpunu homonimiju, tj. istovjetnost i pisanoga i izgovorenog oblika ${ }^{e e}$.

${ }^{76}$ Hudeček, Mihaljević (2009: 162) smatraju bitnim „,govori li se o homonimiji na razini leksema, tj. riječi u svim njezinim oblicima ili na razini pojedinog oblikae. Na razini leksema govore o „homografima (istost pisma), homofonima (istost izgovora) i potpunim homonimima (istost i pisma i izgovora), a na razini oblika donose ova tri odnosa: homografske homoforme (istost pisma pojedinih oblika), homofonske homoforme (istost izgovora pojedinih oblika) i potpune homoforme (istost pisma i izgovora pojedinog oblika ${ }^{e e}$.
} 
U članku stoga nastoje jasnije definirati pojam homonimije. Pravim homonimima smatraju samo one riječi koje pripadaju istoj vrsti riječi, a obličnim homonimima (homoformama) smatraju samo pojedine oblike riječi u homonimnome odnosu. Dakle, homoforme se ne odnose na riječi (lekseme). Hudeček, Mihaljević (2009: 164) definiraju homonimima samo homonime u užem smislu, dakle potpune homonime, a to su ,riječi koje pripadaju istoj vrsti riječi i imaju sve jednake oblike, i to i u izgovoru i u pismu ${ }^{\text {ee }}$. Homonimiju određuju, povodeći se za Tafrom, kao „leksičku pojavu u kojoj dvije ili više riječi pripadaju istom gramatičkom razredu, isto se izgovaraju i imaju sve iste oblike, ali pripadaju različitim semantičkim razredima te nemaju nijednu zajedničku značenjsku sastavnicu ${ }^{e e}$.

\subsubsection{Razdioba homonima}

Da bi dvije riječi bile homonimne, one moraju imati isti fonemski sastav, različita značenja, iste prozodijske značajke i moraju se jednako pisati pa iz toga Samardžija (1989: 7) izvodi i definiciju homonima koje određuje kao „riječi istog fonemskog sastava i slijeda, jednakih prozodijskih značajki, jednake u pismu i različita značenja ${ }^{e e}$. No, isti jezikoslovac tvrdi kako homonimi ne moraju pripadati istom leksičko-gramatičkome razredu ${ }^{77}$ i ne moraju imati jednake sve oblike paradigme te zbog toga razlikuje dvije skupine homonima:

1. pravi homonimi - oni koji pripadaju istoj vrsti riječi i dijele se na potpune i djelomične. Potpunim su homonima istovjetni svi oblici (kòsa imenice ženskoga roda jednine = vlasi i kòsa imenice ženskoga roda jednine $=$ oruđe), a djelomičnima nisu (bïti ${ }^{78}$ od glagola jesam $=$ postojati i bïti od glagola bijem $=$ udarati $)$.

2. nepravi homonimi ${ }^{79}$ - oni koji pripadaju različitim vrstama riječi (blízu - prijedlog i blízu - prilog).

\footnotetext{
${ }^{77}$ Samardžija (2003: 24) bilježi primjer imenice ženskoga roda u genitivu množine ünūkā imenice unuka i imenice muškoga roda u genitivu množine ünūkā imenice unuk, ali i primjer imenice ženskoga roda u genitivu množine pârā imenice para i primjer 3. osobe jednine prezenta pârā od glagola parati. Te homonime naziva obličnima, a uvodi i pojam leksičkih homonima. Zbunjujući je primjer imenice rúža (rúže primjer imenice ženskoga roda u nominativu množine - rúže imenice ženskoga roda u genitivu jednine) koju stavlja u homonimni odnos, a istovremeno traži da jedan od uvjeta homonimije bude i različit semantički sadržaj.

${ }^{78}$ Ove primjere dvaju glagola Tafra ne smatra homonimima.

${ }^{79}$ Tafra (2016: 146) upravo zbog ovog primjera ukazuje na činjenicu kako se često događa „da se različite vrste riječi proglašavaju homonimima jer se zaboravlja da jezične jedinice koje nisu iste razine nisu usporedive. Ako pridjev i prilog, ili kanonski lik i oblik neke promjenjive riječi ne mogu biti sinonimi ili antonimi, logično je da ne mogu biti ni homonimi, ali se u literaturi homonimima proglašava, čini se, bilo kakva izrazna jednakost ili čak sličnost dviju riječi ili njihovih oblika"e. Po Tafri navedeni primjeri nikako ne mogu biti homonimi, već su to homografi.
} 
Melvinger (1984: 38-39) razlikuje više vrsta homonima: leksičke i oblične homonime te homografe i homofone:

1. leksički homonimi - oni koji pripadaju istoj vrsti riječi i formativi su im u svim gramatičkim oblicima ili barem u većini gramatičkih oblika isti. Primjeri su leksičkih homonima ove riječi: $r a k$ (životinja) - rak (zloćudna bolest), kosa (vlasi na glavi) kosa (oruđe kojim se kosi); krma (dio broda) - krma (hrana za stoku)

2. oblični homonimi - oni koji pripadaju različitim vrstama riječi, ali u svojim pojedinim gramatičkim oblicima imaju iste formative: supruga (imenica jednine ženskoga roda u nominativu) - supruga (imenica jednine muškoga roda u genitivu), gol (pridjev) - gol (imenica)

3. homofoni - riječi različitog značenja koje se izgovaraju na isti način, ali se ne pišu isto: $k a t-k a d$ (ispred riječi koje počinju bezvučnim suglasnikom), brat ću (1. osoba jednine futura) i braću (akuzativ jednine imenice braća), Ruža 'vlastito ime' - ruža 'vrsta cvijeta'

4. homografi - riječi različitog značenja čiji se formativi isto pišu, a različito izgovaraju. Budući da se u pismu u našem jeziku ne obilježavaju naglasak i kvantiteta, naši su homografi riječi $\mathrm{s}$ istim fonemskim sastavom, a s različitim prozodijskim obilježjima: pile - pïle, òrao - örao, göra - góra, ròda - röda.

\subsubsection{Načini postanka homonima}

Osim jasnoga definiranja pojmova homonimije, homonima, homografa i homofona, potrebno je navesti i načine postanka homonimije. Ova su četiri uzroka ili načina nastanka homonima najčešće navođena u recentnim literaturama (Hudeček, Mihaljević 1996., Melvinger 1984., Samardžija 2003. i sl.):

1. jezično posuđivanje - homonimijski odnos može se uspostaviti između izvorne riječi i posuđenice ili između dviju posuđenica različita porijekla. Ovi homonimi pripadaju različitim predmetnim i pojmovnim područjima te su njihova značenje posve različita: paša 1. 'pasenje, napasanje', 2. 'pašnjak, ispaša' i paša pov. 'naslov visokih vojnih i civilnih dostojanstvenika u Osmanskom Carstvu i nekim drugim državama' 
2. tvorba riječi - homonimi mogu nastati i tvorbom riječi kad tvorenice tvorene od različitih riječi (tvorbenih osnova), najčešće zbog glasovnih promjena imaju isti oblik. Kod homonima odužiti 'platiti, vratiti dug, učiniti nešto što se smatra kao dužnost, obveza' i odužiti 'oduljiti, načiniti dug(ačk)im; otegnuti, razvući' homonimični su leksički morfemi 'jedno je alomorf leksičkog morfema imenice dûg, a drugo je alomorf leksičkog morfema pridjeva düg'

3. glasovne promjene - homonimi nastaju povijesnim glasovnim razvitkom kojim se različiti oblici različitih riječi izjednačuju: leskem odvesti 'vodeći predvodeći učiniti da tko ili što dođe na određeno mjesto' i odvesti 'otpremiti kakvim prijevoznim sredstvom, vozeći udaljiti' nastali su tako što je kod prvog homonima od stare skupine suglasnika -dt dobiveno -st (vedti - vesti), a kod drugog je homonima izvršeno jednačenje po zvučnosti (vezti - vesti) te su dva različita glasovna procesa dala iste rezultate

4. raspad polisemije ${ }^{80}-\mathrm{u}$ takvim slučajevima među homonimima postoji i stanovita labava podudaranost u značenju. Katkada je zbog toga čak teško i razgraničiti je li riječ o homonimiji ili o polisemiji. Primjeri su: oblačiti 'stavljati odijelo, ruho ili dio odijela na tijelo (svoje ili tuđe)' i oblačiti 'navlačiti oblake, prekrivati oblacima'; odudarati 'vratiti, odbiti udarac' i odudarati 'pasti u oči'; odskakati 'skačući odvojiti se od čega' i odskakati 'otrčati, odjuriti skačući, odskakutati'; palac 'krajnji debeli prst na ruci i nozi' i palac 'poluga koja na točku spaja naplatak s glavčinom žbica', odlučiti 'donijeti odluku, riješiti se na što' i odlučiti 'izdvojiti, odvojiti, odijeliti““ (Melvinger 1984: 39-41).

Tafra (1986: 388-389) navodi ove načine postanka homonimije koji se donose u cijelosti:

1. fonetska slučajnost

a) idioglotema, npr. ključ, mah, topljenje, muk

\footnotetext{
${ }^{80}$ Tafra (2016: 154) smatra da je „najlakše odrediti homonime kad je riječ o posuđenicama koje se slučajno podudaraju s domaćim riječima ili su došle iz različitih jezika jer je odmah jasno da su različita porijekla pa neće biti u pitanju polisemija. Međutim, homonimija može nastati povijesnim procesom raspada polisemije. Rezultat je depolisemizacije dvostran: a) depolisemizacija = homonimizacija (partija ${ }^{1}$ 'stranka', partija ${ }^{2}$ 'dio neke cjeline') ili b) depolisemizacija $\neq$ homonimizacija (pèčēnje i pečénje, kràvetina i kravètina). U prvom se slučaju kidaju semantičke veze između dvaju značenja i svaka riječ ulazi u drugu tvorbenu porodicu te se stoga mogu smatrati homonimima. U drugom slučaju akcent je odigrao ulogu tvorbenoga sredstva pa su od glagolske imenice nastala dva leksema koja znače radnju i rezultat te radnje, a u drugom primjeru razjednačivanjem je augmentativa išlo po liniji neživo:živo pa kràvetina znači 'kravlje meso', a kravètina pejorativno 'žena'..e
} 
b) idioglotema i aloglotema, npr. griz, pasati

c) aloglotema iz istoga jezika, npr. banket, koma, debi

d) aloglotema iz različitih jezika, npr. doza, koral, marka

2. raspad polisemije, npr. park, nota, takt, stolica.

Iako se načelno jezikoslovci slažu oko tih kriterija, Hudeček, Mihaljević (2009: 165) zaključuju „kako su njihova primjena i posebno oprimjerivanje često sporni jer je teško naći dobar primjer, posebno za treći i četvrti način postanka homonima. ${ }^{e}$ Načelno se slažu i s Tafrinom podjelom homonima u navedene skupine, ali ta podjela navodi ih na zaključak da Tafra (1986: 166) smatra kako „homonimi mogu biti i riječi koje pripadaju različitim sustavima te da homonimi ne moraju imati sve iste oblike. " Hudeček, Mihaljević se ne slažu s tim jer smatraju da se u prvome slučaju nikako ne može govoriti o homonimiji budući da je riječ o različitim sustavima, a u drugome slučaju može se govoriti samo o homoformama u kanonskome obliku ${ }^{81}$.

Dakle, iz konteksta navedenoga proizlazi kako se za leksičko-semantičke odnose u jeziku prvenstveno, misleći na homonimiju, trebaju odrediti kriteriji prema kojima dva leksema ili jesu ili nisu homonimi te unutar tih zadanih kriterija proučavati pojavu homonimije. Odlučiti se hoće li se o pojavi homonimije govoriti samo na razini leksema, tj. riječi u svim njezinim oblicima ili i na razini pojedinoga oblika, jasno omeđiti granice homonimije te utvrditi radi li se tu o homonimiji samo ako je riječ o istim vrstama riječi, jasno definirati ulaze li u homonimiju i riječi različitoga normativnog statusa i riječi koje pripadaju različitim dijalektima $^{82}$ ili će se homonimija ograničiti samo na odnose leksema unutar jednoga idioma jednoga jezika ${ }^{83}$.

\footnotetext{
${ }^{81}$ Nadalje, autorice u članku opisuju i brojne druge primjere unutar načina nastanka homonimije te za svaki daju svoj osvrt na ispravnost ili neispravnost istoga. Više o tome u Hudeček, Mihaljević (2009).

${ }^{82}$ Hudeček, Mihaljević (2009: 166) zaključuju da unutar homonimije trebamo govoriti o odnosu leksema koji pripadaju istom sustavu, no za Tafru (1986: 166) ,homonimi mogu biti i riječi koje pripadaju različitim sustavima (npr. standardnom jeziku i dijalektu ili dvama dijalektima) ${ }^{\text {ec }}$.

I Samardžija (1989: 9) razmatra homonimiju između standardnojezične i dijalekatne riječi bilježeći: „I sasvim na kraju ovog omeđivanja pojma književni (standardni) izlučivanjem leksičkih slojeva koji mu ne pripadaju i koji poradi toga ne mogu ući u razmatranje homonimije u književnom jeziku...".

${ }^{83}$ Samardžija (1989: 32) zaključuje kako je „homonimija jednojezični fenomen te je o njoj moguće govoriti samo unutar leksika jednog određenog jezika. Sve podudarnosti formativa riječi iz dva ili više jezika samo su veća ili manja slučajnost, a ne međujezična homonimija koja, ta slučajnost, tek rjeđe upućuje na srodnost jezika ili, češće, služi za duhovite igre riječima. Jednojezična narav homonimije ne isključuje mogućnost poredbenog proučavanja homonimije unutar poredbene leksikologije jer ono, kao što pokazuju neki radovi, može dati zanimljivih i korisnih znanja.e
} 


\subsubsection{Pristup homonimiji u stihovima}

U radu će se na homonimiju gledati kao na pojavu leksičko-semantičkoga paradigmatskog odnosa o kojoj će se moći govoriti samo u slučaju zadovoljenja triju preduvjeta, tj. leksemi u odnosu trebat će zadovoljiti ove kriterije:

1) isti leksičko-gramatički razred

2) jednak fonemski i prozodemski slijed

3) isti vremenski presjek leksičkoga razvoja.

Dakle, za homonimiju su to jednaki izrazi i različiti sadržaji bez ijednoga zajedničkog semantičkog obilježja ${ }^{84}$, a kao osnovna pretpostavka za ostvarivanje leksičko-semantičkoga odnosa homonimije jest pripadnost istoj vrsti riječi. U svim drugim slučajevima promatranoga odnosa među leksemima, gdje svi ovi uvjeti nisu zadovoljeni, govorit ćemo o homoformama, homografima ${ }^{85}$ ili o homofonima ${ }^{86}$ jer homonimi ne mogu biti leksemi koji pripadaju različitim

\footnotetext{
${ }^{84}$ I tu dolazi do određenog sporenja među jezikoslovcima. Naime, Hudeček, Mihaljević (2009: 175) navode kako su „katkad riječi homonimi po načelu da su tvorene od različitih riječi, a nisu po načelu da homonimi ne smiju imati nijedan zajednički sem. Zašto bi homonimi tvoreni od različitih riječi (koje slučajno imaju zajednički sem) morali podlijegati toj obvezi, kad je njihova istoizraznost također slučajna kao i istoizraznost riječi koje nemaju zajedničkih semova? U slučaju u kojem se sukobljavaju tvorbeno načelo i načelo povezanosti značenja, tvorbeno načelo, po autoricama ima neupitnu prednost jer ,od dviju različitih riječi dvama neovisnim tvorbenim postupcima ne možemo dobiti jednu riječ bez obzira na to koliko su značenjski bliske riječi od kojih se tvorbenim postupkom izvode nove riječi i bez obzira na to što i te izvedene riječi u pravilu i po logici imaju također zajednički sem i s riječima od kojih su izvedene i međusobno." $\mathrm{S}$ druge pak strane Tafra (2016) tvrdi kako nije sporno da homonimi u hrvatskom jeziku mogu nastati u tvorbi kad dvije motivirajuće riječi dadu dvije tvorenice jednaka izraza, ali sporno je što „autorice svaki primjer takvih tvorenica automatski smatraju homonimima jer su različite tvorbene osnove makar među njima postojala semantička kohezija. Dopuštanjem da se homonimi mogu djelomice značenjski podudarati, odnosno da mogu imati koji zajednički sem poništavaju najvažniju granicu između homonimije i polisemije, ali i višestruku motivaciju u nastanku riječi." Stoga, u ovome ćemo se radu držati Tafrina stajališta i taj kriterij primjenjivati.

${ }^{85}$ Tafra (1986: 384-385) navodi kako je ,problem u tome što nema jedinstvenog mišljenja što su homonimi. Jesu li to istopisnice ili istozvučnice, spadaju li u istu vrstu riječi, moraju li zadovoljavati kriterij identičnosti na planu izraza samo u rječničkoj formi (normativnoj i infinitivnoj) ili moraju imati jednake i sve alolekse? Homonimija se često poistovjećuje s homografijom. Stoga u definiranju homonima ne treba izbjegavati činjenicu da su svi homonimi ujedno i homografi, ali svi homografi nisu homonimi." Primjere leksema unuka $\mathrm{N}$ jednine imenice ženskoga roda i unuka $\mathrm{G}$ jednine imenice muškoga roda, te odnos leksema gol u službi imenice i gol u službi pridjeva ne smatra homonimima.

${ }^{86}$ Tafra (1986: 385) napominje kako se „homonimija često izjednačuje i s homofonijom, ali svaka homofonija nije homonimija. Homofonija je mnogo širi pojam od homonimije, pa naš naziv istozvučnica za homonim ne odgovara u potpunosti. Budući da postoji ograničen broj fonema i ograničena njihova distribucija, mogućnost da se ponove iste kombinacije dosta je velika. Osim homografa i homofona javljaju se još neki nazivi: homoforme (kosti, kosti, kosti), homorfemi (šuma - konja, šume - konje), sinkretizam (šumama DLI mn.), konverzija (dobro pridjev dobro prilog - dobro imenica). Ne može se svaka identičnost na planu izraza smatrati homonimijom jer osim nje uvjet za homonimiju jest i odsutnost semantičke kohezije."

Tafra samo u primjerima onimizacije (višnja $>$ Višnja) i deonimizacije (Tesla $>$ tesla) smatra opravdanim uspoređivanje opće imenice i imena zbog tvorbene motivacije, jer (2016: 149) navodi „kako se među apelativima i onimima ne traže sinonimi, paronimi i antonimi, ne bi se trebali tražiti ni homonimi. Imena su poseban leksički sustav koji služi za identifikaciju izvanjezičnoga svijeta, a homonimija je izrazno-sadržajni odnos među riječima. ${ }^{. e}$
} 
vrstama riječi, niti su to riječi iz dvaju razdoblja, a nisu ni kanonski lik riječi i oblik promjenjive riječi. Dakle, homonimija će za potrebe ovoga rada obuhvaćat prave homonime ${ }^{87}$, homoforme, ali i homofone i homografe s jasnim određenjem koji odnosi pripadaju kojoj vrsti.

Pri analizi homonimije nastojat će se jasno razgraničiti jezična (leksička) i nejezična (slovopisna i pravopisna) razina, pripadnost različitim vrstama riječi, kanonski lik i oblik riječi, te uzimanje naglaska kao razlikovnoga sredstva u riječima hrvatskoga jezika ne bi li se homonimija dosljednije i sustavnije obradila.

Rad će se stoga sastojati od dva dijela. U prvome će se prikazati analiza homonima, homoformi, homografa i homofona na konkretnim primjerima dvostiha Jankovićeva i Lukićeva korpusa dok će se u drugome dijelu na primjerima dijelova dvostiha ukazati na ovjerenost potencijalnih homonima, homografa, homoformi i homofona deseteračkih dvostiha $u$ rječnicima uzimajući prethodno navedene kriterije te prateće rječnike (Anić 2003., Brodnjak 1992, Klaić 2002.).

Potonje je vrlo važno kako bi se ukazalo na veliku neujednačenost navođenja homonima, homoformi, homografa i homofona u različitim rječnicima. Naime, razlog tomu su nejedinstveni stavovi o značenju homonimije i o razgraničavanju polisemije od homonimije pa su rječnici, kao i teorijska literatura, kada je u pitanju homonimija i polisemija nesložni i nejednoznačni kako bilježi Cruse (2007: 132-133): „Dictionaries usually treat homonymy and polysemy differently: homonymous readings are given separate main headings, while polysemous readings are typically distinguished by means of numbers under a single main heading. Some dictionaries make the distinction between homonymy and polysemy on etymological grounds, that is to say, meanings which have the same etymological origin are considered to be polysemous, even if modern speakers can intuit no relation between them, as in the case of battery ('infliction of blows', 'set of similar or connected cells'), both of which derive from the French batterie, while meanings which are usually felt to be related are treated as homonymy if they have different etymological origins, as in the case of ear ('organ of hearing' and 'grain of corn on stalk'). It should be pointed out that although the distinction between homonymy and polysemy is clear enough in extreme cases, the boundary between

\footnotetext{
${ }^{87} \mathrm{U}$ radu će se oni smatrati i nadalje bilježiti kao homonimi jer kako Tafra (2016: 152) navodi govoreći „o pravim (punim) i nepravim (djelomičnim) homonimima, potpunim i nepotpunim, o homonimima u užem i širem smislu, otvaramo previše pitanja i dvojbiee, a iz njezina je grafička prikaza homonimije (str. 149) jasno „da nema sličnosti ni na planu izraza ni na planu sadržaja pa odnos dvaju leksema ne može biti potpun ili nepotpun."
} 
them is not very well defined. Not only is there a continuous scale of relatedness, but different speakers vary in their sensitivity to relationships“.

Zbog toga se leksikografi pri samom sastavljanju rječnika često povode različitim kriterijima po kojima definiraju homonime, homoforme, homografe ili homofone te polisemiju, a rezultat su toga neujednačeni rječnici što će analiza i pokazati.

\subsubsection{Homonimi u deseteračkim dvostisima}

Uzimajući u obzir navedene kriterije po kojima su dva leksema u homonimnome odnosu, analiza korpusa Jankovićevih i Lukićevih dvostiha pokazala je da je „pravih“ homonima zaista malo. Naime, u Jankovićevim se zapisima ne pojavljuju dok je kod Lukića zabilježen samo jedan par istoglasnica u stihovima.

\section{Lipa seka, dok je apoteka, sunce sini, apoteku skini.}

Iako je leksem apoteka u Anićevu Velikom rječniku hrvatskoga jezika ${ }^{88}$ (2003) višeznačan te označava 1. 'mjesto gdje se stručno priređuju i prodaju lijekovi; ljekarna', odnosno 2. iron. 'mjesto gdje je sve skupo, gdje se prodaje po visokim cijenama' ni jednim svojim značenjem taj leksem nije ni približan značenju koje on ostvaruje u stihu. Šminka ili 'sredstvo za uljepšavanje' opis je natuknice njemačkoga podrijetla koja je vjerojatno uslijed uporabe u govoru proširila svoje značenje i tijekom vremena udaljila se od izvornog značenja posuđenice i zadobila u potpunosti novo značenje. U ovom je primjeru dvostiha kontekst ključan, a za razumijevanje homonimije upravo je vrlo važan kontekst ${ }^{89}$ u kojem se homonimi pojavljuju.

\footnotetext{
${ }^{88}$ Dalje VRHJ.

${ }^{89}$ Prema Tafri (1986: 383) „Homonimi su u potpunoj ovisnosti o kontekstu. Sama riječ bor ili kosa u nama ne izaziva nikakvu predodžbu. Tek na nivou sintagme (primorski bor) ili rečenice (Bor dolazi u dvije alotropske modifikacije.) ili diskursa (Doktorirao je na temi o boru. Obećali su mu mjesto na fakultetu jer je doktoratom pokazao da je izvanredan mlad znanstvenik. Bio je do tada najmlađi doktor kemije.) razrješava se 'homonimni konflikt'،. Međutim, ni kontekst ne može uvijek jednoznačno odgovoriti na homonimski konflikt i Tafra navodi da slušalac obično pogađa o čemu je riječ, ali ne mora uvijek biti tako. Samardžija (1989: 4) zaključuje da u hrvatskom jeziku ponekad nastaju rečenice čiju dvoznačnost ne otklanja ni kontekst, (npr. Njegovi roditelji imaju šest unuka.) nije jasno radi li se o unukama ili o unucima. U navedenom primjeru riječ je o gramatičkim, odnosno morfološkim homonimima.
} 


\subsubsection{Oblični homonimi (homoforme) u deseteračkim dvostisima}

O obličnoj je homonimiji riječ kad su izrazi oblika različitih riječi, koje mogu pripadati i različitim vrstama riječi, istovjetni (Hudeček, Mihaljević, 2009: 161-162). Obličnim se homonimima ili homoformama, dakle, smatraju i oblici koji mogu pripadati različitim vrstama riječi te samo u pojedinim svojim gramatičkim oblicima imaju jednak izraz, jednako se izgovaraju u tim izrazima, ali su im značenja različita. Naime, homoforme se ne odnose na lekseme kao homonimi, homografi ili homofoni već samo na pojedine oblike tih odnosnih leksema (nav.dj.: 164). Takvih je obličnih homonima u korpusu neznatno, ali ih je nekolicina zabilježena:

Jankovićevi zapisi

Vesela sam, čula sam čija sam, čija majka zove mene snajka.

Oči moje titore ko svića,

'ko me ljubi, dugo me se sića.

Žito voza moja mila dika, čim me spazi sa voza silazi.
Lukićevi zapisi

Kad te sretnem, srce mi zalupa, Nekad davno mi smo bili skupa.

Vjetar puše i po malo 'ladi, puno lipi, a malo je dragi.

Dikina mi kuća priko puta, pa ga vidim na dan po sto puta.

Crne oči crne se u glavi,

ko jagode u zelenoj travi.

U primjerima dvostiha izdvojeni oblični homonimi različita su značenja te pripadaju uglavnom različitim vrstama riječi, ali im je prozodijsko obilježje u navedenome obliku jednako: čija (veznik) - čija (pridjevska zamjenica), kö (veznik) - 'kö (odnosna zamjenica), vôza (3. os. jd. gl. vozati) - vôza (G, jd. m.r. im. voz), cr̈ne (N mn. s.r. pridj. crn) - cr̈ne (3. os. mn. gl. crniti se), mî (D jd. zamj. ja) - mî ( $\mathrm{N} \mathrm{mn.} \mathrm{zamj.} \mathrm{mi),} \mathrm{mälo} \mathrm{(prilog} \mathrm{načina)} \mathrm{-} \mathrm{mälo} \mathrm{(prilog}$ količine), púta (G jd. m.r. im. put) - púta (pril. čest.).

\subsubsection{Homografi u deseteračkim dvostisima}

Homografi ili istopisnice definiraju se riječima različita značenja čiji se izrazi jednako pišu, ali različito izgovaraju. To su riječi različite vrste, tj. različitoga leksičko-gramatičkog razreda, različitoga roda ili vida, te povratni i nepovratni glagoli, odnosno nepravi povratni i 
pravi povratni glagoli, riječi različita naglaska ili riječi različita oblika vidljivima kroz paradigmu. No, postoje i primjeri homografa koji pripadaju istoj vrsti riječi te pri tom imaju istu sklonidbu, ali nemaju isti naglasak u svim oblicima.

Homografi su najbrojniji u korpusu Jankovićevih i Lukićevih zapisa.

Jankovićevi zapisi

Šareni se šareni salvetak, dojdi, diko, makar bio petak.

Blago ljubi, kad ju jedan ljubi ... Teško, zlo je, kad ji bude dvoje.

Skidaj, curo, te dukate s vrata, da ja lupam o birtaška vrata!

Misečina uprla u vrata, di se dvoje grle oko vrata.

Oj kako su medeni divani, kada dvoje divani po strani.

Diko, daj mi maramicu moju, daj, molim te, više ne volim te!

\section{Lukićevi zapisi}

One seke što su priko Save, one nose krunice na glave.

Diku diči kosa po po čela, mene mladu dva obraza biela.

Mjesečina uprla u vrata, Ge me dika grli oko vrata.

Kolo malo ide polagano, malo veće samo se okreće.

Da zna nana što zna lipa mala, već bi davno lipu podrezala.

A šta će mi i zlato i drago, da je meni, što je srcu drago.

Usta moja malena i fina, od malena ljube gospodina.

Izdvojeni homonimni leksemi većinom pripadaju različitim vrstama riječi i različite su akcentuacije: šarèni (se) (3. os. jd. gl. šareniti se) - šàreni (Njd. m.r. pridj. šaren), ljúbi (D jd. ž.r. im. ljuba) - ljûbi (3. os. jd. gl. ljubiti), (s) vrâta (G jd. m.r. im. vrat) - (o) vráta (A pl. tantum, s.r. im. vrata), (u) vráta (A pl. tantum, s.r. im. vrata) - (oko) vrâta (G jd. m.r. im. vrat), diváni (N mn. m.r. im. divan) - dìvani (3. os. mn. gl. divaniti), dâj (2. os. jd. gl. dati) - däj (uzvik), màlena ( $\mathrm{N}$ mn. s.r. pridj. malen) - (od) malèna (prilog vremena), ône ( $\mathrm{N}$ mn. ž.r. pokazna zamjenica ona) - òne (3. os. mn. osobn. zamj. one), pö (prijedlog) - pô (čestica), mâlo (N jd. s.r. pridj. mal) - mälo (prilog), lîpa (N jd. ž.r. pridj. lijep) - lïpa (A jd. ž.r. im. lipa), drâgo (A jd. s.r. im. drago $o^{90}$ ) - drágo (A jd. s.r. pridj. drag).

\footnotetext{
${ }^{90} \mathrm{U}$ prenesenome značenju 'draga osoba'. VRHJ ne bilježi taj leksem.
} 


\subsubsection{Homofoni u deseteračkim dvostisima}

Homofoni ili istozvučnice riječi su različita značenja koje se akcentiraju, tj. izgovaraju na jednak način, ali se ne pišu jednako. Samo je jedan par homofona zabilježen u korpusu i to u usporednim tekstovima dvojice autora.

Jankovićevi zapisi

U milana srce od ljiljana, i u mene pa za njime vene.
Lukićevi zapisi

U Milana srce od ljiljana,

I u mene, pa za njime vene.

Leksemi koji čine homonimni par pripadaju imenicama, ali različitim vrstama: milana (A jd. m.r. op. im. milan) - Mìlana (A jd. m.r. vl. im. Milan). Izdvojeni leksem Lukićeva zapisa rezultat je onimizacije, odnosno deapelativizacije, koja „označava proces prelaska opće imenice u vlastito ime, odnosno onim (Šivic-Dular 1999: 286)“.

\subsubsection{Ovjerenost leksema kao homonima, homoformi, homografa i homofona}

U korpusu Jankovićeva i Lukićeva zapisa utvrđeni su i leksemi koji izvan navedena korpusa imaju svoj homonimni parnjak. Njihova se ovjerenost provjeravala u trima rječnicima; Velikom rječniku hrvatskoga jezika Vladimira Anića (2003), Rječniku stranih riječi Bratoljuba Klaića (2002) i u Rječniku razlika između hrvatskoga i srpskoga jezika Vladimira Brodnjaka (1992). U rječnicima je provjerena njihova natuknica te je kao takva i potvrđena iako i u samim rječnicima postoje određena razilaženja u vidu njihova navođenja te bilježenja njihovih naglasaka. U svakom primjeru toga razilaženja navedena je bilješka.

Potreba za ovakvom vrstom navođenja homonima, homoformi, homografa te homofona i njihove ovjerenosti u postojećim rječnicima nužna je iz nekoliko razloga:

a) dokumentiranjem pojedinih leksema moguća je dopuna rječničkog opisa hrvatskoga jezika

b) ukazivanjem na propuste u bilježenju pojedinih leksema i njihove akcentuacije potrebno je srediti njihovo postojeće stanje. 
Radi preglednosti i lakše snalažljivosti u tekstu, prikaz homonima, homografa, homoformi i homofona bit će tabličan.

\subsubsection{Ovjerenost homonima}

Tablica 3. Homonimi i njihova kategorizacija u rječnicima

\begin{tabular}{|c|c|c|c|}
\hline Dijelovi stiha & $\begin{array}{l}\text { Zabilježeni } \\
\text { oblik }\end{array}$ & $\begin{array}{l}\text { Izdvojeni homonim }^{91} \mathrm{i} \\
\text { njegovo značenje }\end{array}$ & $\begin{array}{l}\text { Homonimni par ili niz } \\
\text { i njegovo značenje }\end{array}$ \\
\hline Češljam kosu i gore i dolje & im. ž.r. jd. A & $\begin{array}{l}\text { kosa }^{\mathbf{1}} \\
\text { 'vlasi na glavi čovjeka' }\end{array}$ & $\begin{array}{l}\text { kosa }^{2} \text { 'blaga strana } \\
\text { brijega ili planine; } \\
\text { padina' } \\
\text { kosa }^{3} \text { 'oruđe za rad' }\end{array}$ \\
\hline Oko moje, diko, oko tvoje & im. s.r. jd. N & oko $^{1}$ 'organ vida' & $\begin{array}{l}\text { oko ' 'biljka; pustošna } \\
\text { žutenica' }\end{array}$ \\
\hline Čičak mali raste u šikari & $\begin{array}{l}\text { im. m.r. jd. } \\
\mathrm{N}\end{array}$ & $\begin{array}{l}\text { čičak }{ }^{1} \\
\text { repušina' }\end{array}$ & $\begin{array}{ll}\text { čičak }^{2} & \text { 'samoljepljiva } \\
\text { vrpca' } & \end{array}$ \\
\hline ... i na slogu debeloga djogu & $\begin{array}{l}\text { im. m.r. jd. } \\
\text { L }\end{array}$ & $\begin{array}{ll}\text { slog1 }^{1} & \text { 'preorana } \\
\text { zemlja'92 } & \end{array}$ & $\begin{array}{l}\operatorname{slog}^{2} \quad \text { 'najmanja } \\
\text { ritmička jedinica' }\end{array}$ \\
\hline Udovice popišana tura & im. ž.r. jd. V & $\begin{array}{l}\text { udovica }^{1} \text { 'ona kojoj je } \\
\text { umro muž' }\end{array}$ & $\begin{array}{l}\text { udovica }^{2} \text { 'biljka iz } \\
\text { porodice češljugovina' }\end{array}$ \\
\hline Peva peto u šupi na rudi & $\begin{array}{l}\text { im. ž.r. jd. } \\
\text { L }\end{array}$ & $\begin{array}{l}\text { ruda }^{1} \text { ' drveni komad, } \\
\text { poluga uglavljena u } \\
\text { prednji trap zaprežnih } \\
\text { kola' }\end{array}$ & $\begin{array}{l}\text { ruda }^{2} \text { 'rudna masa na } \\
\text { nekom terenu; mineral, } \\
\text { rudača' }\end{array}$ \\
\hline Daleko se čuje bisernica & im. ž.r. jd. N & $\begin{array}{l}\text { bisernica }^{1} \text { 'tamburica } \\
\text { najvišeg tona' }\end{array}$ & $\begin{array}{l}\text { bisernica }^{2} \quad \text { 'školjka } \\
\text { koja stvara biser' }\end{array}$ \\
\hline Za prkos me i rodila mama & $\begin{array}{l}\text { im. m.r. jd. } \\
\text { A }\end{array}$ & $\begin{array}{l}\text { prkos }^{1} \text { 'tvrdoglavost, } \\
\text { inat' }\end{array}$ & prkos $^{2}$ 'ukrasna biljka' \\
\hline
\end{tabular}

\footnotetext{
${ }^{91}$ Izdvojeni homonimi u tablici nemaju zabilježen naglasak jer je on isti u izdvojenome primjeru, ali i u njegovome homonimnom paru.

${ }^{92}$ Definicija leksema nije zabilježena u VRHJ-u niti u ostalim rječnicima.

${ }^{93}$ Iako je taj leksem u VRHJ-u naveden kao primjer polisemije gdje ta natuknica ima dva značenja, autorica ih smatra homonimima jer ih ne veže ni jedan zajednički sem.
} 


\begin{tabular}{|c|c|c|c|}
\hline U inoče zubi ko lopari & $\begin{array}{l}\text { im. m.r. mn. } \\
\mathrm{N}\end{array}$ & $\begin{array}{l}\text { lopar }^{1} \text { 'drvena lopata } \\
\text { kojom se vadi kruh iz } \\
\text { krušne peći' }\end{array}$ & $\begin{array}{ll}\operatorname{lopar}^{2} \text { 'biljka } & \text { iz } \\
\text { porodice kozlaca' } & \end{array}$ \\
\hline Oj derane u crvenom fesu & $\begin{array}{l}\text { im. m.r. jd. } \\
\text { L }\end{array}$ & $\begin{array}{l}\text { fes }{ }^{1} \text { 'kapa bez oboda, s } \\
\text { kićankom ili bez nje' }\end{array}$ & $\begin{array}{l}\text { fes }^{2} \text { 'kromatski sniženi } \\
\text { ton } f^{\prime}\end{array}$ \\
\hline ne bi žena nosila modrica & $\begin{array}{l}\text { im. ž.r. mn. } \\
\mathrm{G}\end{array}$ & $\begin{array}{l}\text { modrica }{ }^{1} \text { 'hematom, } \\
\text { plavica' }\end{array}$ & $\begin{array}{l}\text { modrica }^{2} \text { 'biljka mišje } \\
\text { uho' }\end{array}$ \\
\hline plave oče to su lipe boje & $\begin{array}{l}\text { im. ž.r. mn. } \\
\mathrm{N}\end{array}$ & $\begin{array}{l}\text { boja }^{1} \text { 'utisak što ga na } \\
\text { oko čini neka pojava } \\
\text { svojim zračenjem' }\end{array}$ & boja' 2 'plutača' \\
\hline $\begin{array}{l}\text { Ljubit ću te valjda nisam } \\
\text { nona }\end{array}$ & im. ž.r. jd. N & $\begin{array}{l}\text { nona }^{1} \text { 'redovnica, } \\
\text { koludrica' }\end{array}$ & nona ${ }^{2}$ 'baka' \\
\hline već udaju jutra i frtalji & $\begin{array}{l}\text { im. s.r. mn. } \\
\mathrm{N}\end{array}$ & $\begin{array}{l}\text { jutro }^{1} \text { 'stara mjerna } \\
\text { jedinica za površinu } \\
\text { zemljišta' }^{94}\end{array}$ & $\begin{array}{l}\text { jutro }^{2} \text { 'prvi dio dana, } \\
\text { vrijeme od svitanja do } \\
\text { podneva' }\end{array}$ \\
\hline za me nema dorana и žире & im. ž.r. jd. L & $\begin{array}{l}\text { župa }^{1} \quad \text { 'najmanja } \\
\text { administrativna } \\
\text { jedinica } \quad \text { Katoličke } \\
\text { crkve' }\end{array}$ & $\begin{array}{ll}\text { župa }^{2} & \text { 'predio izložen } \\
\text { suncu i } & \text { zaklonjen } \\
\text { vjetru; } & \text { pitomina, } \\
\text { prisoje' } & \end{array}$ \\
\hline kog ti volja, onog si ljubila & im. ž.r. jd. N & volja' ${ }^{1}$ 'želja za čim' & $\begin{array}{ll}\text { volja }^{2} & \text { 'prošireni dio } \\
\text { želuca } & \text { u životinje; } \\
\text { guša' } & \end{array}$ \\
\hline men' bi fratri pomagali tkati & $\begin{array}{l}\text { im. m.r. mn. } \\
\mathrm{N}\end{array}$ & $\begin{array}{l}\text { fratar' }^{1} \text { 'redovnik } \\
\text { nekog katoličkog reda' }\end{array}$ & $\begin{array}{l}\text { fratar }^{2} \quad \text { 'srebrnkasta } \\
\text { riba koštunjača' }\end{array}$ \\
\hline metla šila ne bil se nabila & im. s.r. jd. G & $\begin{array}{l}\text { šilo }{ }^{1} \text { 'debela igla oštra } \\
\text { vrha' }\end{array}$ & $\begin{array}{l}\text { šilo }^{2} \quad \text { 'morska riba } \\
\text { koštunjača' }\end{array}$ \\
\hline Oj inočo, umij se u lugu & $\begin{array}{l}\text { im. m.r. jd. } \\
\text { L }\end{array}$ & $\begin{array}{l}\text { lug' 'voda u kojoj je } \\
\text { prokuhan pepeo' }\end{array}$ & lug'2 'šumarak, gaj' \\
\hline moj je lola, ić ćemo do suda & $\begin{array}{l}\text { im. m.r. jd. } \\
\text { G }\end{array}$ & sud $^{1}$ 'sudište' & sud $^{2}$ 'posuda' \\
\hline
\end{tabular}

${ }^{94}$ U VRHJ-u leksem jutro 'stara mjerna jedinica' nije naveden kao zasebna natuknica. No, potrebno ju je posebno obrojčiti i smatrati novim leksemom jer s leksemom jutro 'prvi dio dana' nema nikakve poveznice, tj. ni jedan zajednički sem. Hudeček, Mihaljević (2009: 167) smatraju da je ovaj primjer stare mjerne jedinice nastao raspadom polisemije. 


\begin{tabular}{|c|c|c|c|}
\hline obriši se o traljavu gubu & im. ž.r. jd. A & guba1 'gubica, njuška' & $\begin{array}{l}\text { guba }^{2} \text { 'gljiva koja raste } \\
\text { na stablu' }\end{array}$ \\
\hline Oženi se šiša i goliša & im. ž.r. jd. N & $\begin{array}{l}\text { šiša }^{1} \text { 'pogrdni naziv na } \\
\text { siromašnu osobu' } 95\end{array}$ & šiša' 'boca, staklenka' \\
\hline $\begin{array}{l}\text { kada ljubim mladog } \\
\text { sekretara }\end{array}$ & $\begin{array}{l}\text { im. m.r. jd. } \\
\text { A }\end{array}$ & sekretar1 'tajnik' & $\begin{array}{l}\text { sekretar }^{2} \quad \text { 'afrička } \\
\text { ptica, uništava zmije' }\end{array}$ \\
\hline kad me sablja po kecelji dira & im. ž.r. jd. N & $\begin{array}{l}\text { sablja }^{1} \text { 'vrsta hladnog } \\
\text { oružja' }\end{array}$ & $\begin{array}{l}\text { sablja }^{2} \text { 'morska riba iz } \\
\text { porodice sabljarki' }\end{array}$ \\
\hline Sad je diko od ljubavi huja & im. ž.r. jd. N & $\begin{array}{l}\text { huja' 'bijes, velika } \\
\text { srdžba' }\end{array}$ & $\begin{array}{ll}\text { huja }^{2} & \text { 'prestanak, } \\
\text { odmor' } & \end{array}$ \\
\hline Igraj, curo, valjda nisi baba & im. ž.r. jd. N & baba $^{1}$ 'stara žena' & $\begin{array}{l}\text { baba }^{2} \text { 'mali željezni } \\
\text { nakovanj' }\end{array}$ \\
\hline A što će mi suknja sa garniri & $\begin{array}{l}\text { im. m.r. mn. } \\
\text { I }\end{array}$ & $\begin{array}{l}\text { garnir'1 'poruba, } \\
\text { volan, nabor' }\end{array}$ & garnir $^{2}$ 'prilog jelu' \\
\hline Dojdi diko i ponesi deku & im. ž.r. jd. A & deka $^{1}$ 'pokrivač' & $\begin{array}{l}\text { deka }{ }^{2} \text { 'mjerna jedinica, } \\
\text { dekagram' }\end{array}$ \\
\hline Ja sam diku ljubila u žalu & $\begin{array}{l}\text { im. m.r. jd. } \\
\text { L }\end{array}$ & žal1 'žaljenje za čim' & $\begin{array}{l}\text { ̌̌al }^{2} \text { 'obala mora } \\
\text { izložena valovima' }\end{array}$ \\
\hline jedan baja iz našega kraja & $\begin{array}{l}\text { im. m.r. jd. } \\
\mathrm{N}\end{array}$ & baja $^{1}$ 'stariji čovjek' & baja $^{2}$ hip. 'od brat' \\
\hline Pletem kiku od crni' konaca & $\begin{array}{l}\text { im. m.r. mn. } \\
\text { G }\end{array}$ & $\begin{array}{l}\text { konac' }^{1} \text { 'nit koja služi } \\
\text { za šivanje' }\end{array}$ & konac $^{2}$ 'svršetak, kraj' \\
\hline bale brišu, za nama uzdišu & $\begin{array}{l}\text { im. ž.r. mn. } \\
\text { A }\end{array}$ & $\begin{array}{l}\text { bala }^{1} \text { 'gust iscjedak iz } \\
\text { nosa; šmrklja' }\end{array}$ & $\begin{array}{l}\text { bala }^{2} \text { 'svežanj uvijene } \\
\text { mekane robe, naramak' }\end{array}$ \\
\hline treba grlo za nedilju šparati & im. s.r. jd. A & $\begin{array}{l}\text { grlo }^{1} \\
\text { 'ždrijelna duplja } \\
\text { s grkljanom i } \\
\text { jednjakom' }\end{array}$ & grlo $^{2}$ 'stoka, marva'96 \\
\hline Devet redi u ormanu gledi & $\begin{array}{l}\text { im. m.r. jd. } \\
\text { L }\end{array}$ & $\begin{array}{l}\text { orman }^{1} \text { 'ormar, dio } \\
\text { pokućstva' }\end{array}$ & orman² 'šuma' \\
\hline devet dana, ko i tvoja nana & im. ž.r. jd. N & nana1 'majka' & nana $^{2}$ 'metvica' \\
\hline
\end{tabular}

\footnotetext{
${ }^{95}$ Vlastita interpretacija pojma jer isti nije naveden niti u jednom rječniku.

${ }^{96}$ Ovog značenja pod natuknicom u VRHJ-u nema niti je navedena u drugim rječnicima.
} 


\begin{tabular}{|c|c|c|c|}
\hline Pasiraju dukati i svila & $\begin{array}{l}\text { im. m.r. mn. } \\
\mathrm{N}\end{array}$ & dukat $^{1}$ 'zlatnik' & $\begin{array}{l}\text { dukat }^{2} \text { 'vojvodstvo, } \\
\text { vojvodina' }\end{array}$ \\
\hline to će nama lipo pasirati & $\begin{array}{l}\text { 3. os. mn. gl. } \\
\text { fut. }\end{array}$ & $\begin{array}{l}\text { pasirati }^{1} \text { 'odgovarati, } \\
\text { pristajati' }\end{array}$ & $\begin{array}{l}\text { pasirati }^{2} \quad \text { 'protisnuti } \\
\text { kroz sito' }\end{array}$ \\
\hline $\begin{array}{l}\text { mama štuca, pa od muke } \\
\text { puca }\end{array}$ & $\begin{array}{l}\text { 3. os. jd. gl. } \\
\text { prez. }\end{array}$ & $\begin{array}{l}\text { štucati }^{1} \quad \text { 'patiti od } \\
\text { trzaja ošita' }\end{array}$ & $\begin{array}{l}\text { štucati }^{2} \text { 'podrezivati, } \\
\text { kresati (bradu, granje)' }\end{array}$ \\
\hline Al' ako sam i ovako pusta & prid. ž.r. & pust $^{1}$ 'koji je razuzdan' & pust $^{2}$ 'koji je bez ljudi' \\
\hline
\end{tabular}

Kroz tablicu je uočljivo kako se navedeni homonimi i njihovi homonimni parovi drže zadanih kriterija - pripadaju istoj vrsti riječi, jednakoga su izraza, istoga naglaska u svim oblicima i različitoga značenja bez ijednoga zajedničkog semantičkog obilježja. No, kod pojedinih parova leksema (sud, lug, dukat) svi padežni oblici nemaju jednake naglaske ( $\mathrm{G}$ jd. súda i sûda, G mn. dukáta i dükātā). No, te se male razlike mogu neutralizirati jer citirajući Tafru (2016: 153): „Za neka odstupanja od prototipnih primjera moguće je primijeniti postupak neutralizacije. Dosljedna primjena nekad neće biti moguća iz različitih razloga bilo na izraznom bilo na sadržajnom planu, kao što je postojanje naglasnih dubleta, nesuglasnost oko gramatičkih kategorija, itd. ${ }^{c e}$

\subsubsection{Ovjerenost homoformi}

Tablica 4. Homoforme i njezina kategorizacija u rječnicima

\begin{tabular}{|l|l|}
\hline \multirow{2}{*}{ Dijelovi stiha } & Izdvojeni leksem i njegovo značenje \\
\cline { 2 - 2 } & Homoforme i njezina značenja \\
\hline svu bi tugu poslala po cugu & cúgu -> L jd. m.r. im. cûg 'vlak, željeznica' \\
\cline { 2 - 2 } & cúgu -> A jd. ž.r. im. cúga ${ }^{97}$ reg. žarg. 'piće' \\
\hline Moja lola i šije i para & pâra -> 3. os. jd. gl. párati 'poriti, rašivati' \\
\cline { 2 - 2 } & $\begin{array}{l}\text { pâra -> G mn. ž.r. im. pära 'stanje u koje prelazi tekućina } \\
\text { pri zagrijavanju' }\end{array}$ \\
\hline Ijubi, diko, kad se lude dadu & dádu -> 3. os. jd. gl. däti se 'prepustiti se čijem utjecaju' \\
\cline { 2 - 2 } & dádu -> A jd. m.r. im. dádo 'otac' \\
\hline
\end{tabular}

${ }^{97} \mathrm{U}$ VRHJ-u ta natuknica ne postoji. 


\begin{tabular}{|c|c|}
\hline & ìmām -> N jd. m.r. im. ìmām 'islamski vjerski službenik' \\
\hline \multirow[t]{2}{*}{ Dika stara priko kola šara } & stâra -> N jd. ž.r. prid. stär 'vremešan' \\
\hline & stâra -> N jd. ž.r. im. stâra 'stara žena' \\
\hline \multirow[t]{2}{*}{ nek, joj puca džigerica bila } & pùca od gl. pücati 'razlomiti se na dijelove' \\
\hline & püca $\mathrm{N}$ jd. ž.r. im. püca 'djevojka, cura' \\
\hline \multirow[t]{2}{*}{ Za 'ne lole koje luku žvale } & žväle -> 3. os. mn. gl. žväliti pejor. žarg. 'ljubiti' \\
\hline & $\begin{array}{l}\text { žväle -> N mn. ž.r. im. žväle 'mentalni dio uzde koji se } \\
\text { stavlja konju u usta' }\end{array}$ \\
\hline \multirow[t]{2}{*}{ Mene grde po selu beštije } & gr̂̀de -> 3. os. mn. gl. gŕditi 'koriti' \\
\hline & gr̂de -> N mn. ž.r. prid. gr̂d reg. žarg. 'ružan' \\
\hline \multirow[t]{2}{*}{ Što on vata sarvaša u logov } & väta -> 3. os. jd. gl. hvätati 'uzimati u ruke' \\
\hline & väta -> N jd. ž.r. im. väta 'vlaknasta tvorevina od pamuka' \\
\hline \multirow[t]{2}{*}{ kad se skobe, dol' oči obore } & òbore -> 3. os. mn. gl. obòriti 'srušiti' \\
\hline & òbore -> A mn. m.r. im. òbor 'ograđen prostor za stoku' \\
\hline \multirow[t]{2}{*}{ Pivaj, ori, pa prkosi loli } & òri -> 2. os. jd. gl. òriti se 'odjekivati' \\
\hline & òri -> 2. os. jd. gl. òrati 'praviti brazde u zemlji plugom' \\
\hline \multirow[t]{2}{*}{ nisu meni dodijali dani } & dâni -> N mn. m.r. im. dân 'doba, vrijeme' \\
\hline & dâni -> prid. trp. mn. m.r. od gl. dàti 'predati' \\
\hline \multirow[t]{2}{*}{ a što koga moja dika košta } & köšta -> 3. os. jd. gl. köštati 'stajati, imati cijenu' \\
\hline & köšta -> N jd. ž.r. im. köšta reg. 'hrana, prehrana' \\
\hline \multirow[t]{2}{*}{ Crna kapa i kajiš crveni } & käpa -> N jd. ž.r. im. käpa 'pokrivalo za glavu \\
\hline & käpa -> 3. os. jd. gl. käpati 'padati kap po kap' \\
\hline \multirow[t]{2}{*}{ Dođi, diko, i ponesi grade } & $\begin{array}{l}\text { grâde -> A mn. m.r. im. grâd 'naziv za stupanj raznih } \\
\text { mjernih ljestvica' }\end{array}$ \\
\hline & grâde -> 3. os. mn. gl. gráditi 'zidati, podizati' \\
\hline \multirow[t]{2}{*}{ Gospodine i gospocki sine } & $\begin{array}{l}\text { sîne -> V jd. m.r. im. sîn 'osoba muškoga spola prema } \\
\text { svojim roditeljima' }\end{array}$ \\
\hline & sîne -> 3. os. jd. gl. sínuti 'iznenada se pojaviti u svijesti' \\
\hline \multirow[t]{2}{*}{ Moj se dika na mašini voza } & vôza -> 3. os. jd. gl. vózati 'vozikati (se)' \\
\hline & $\begin{array}{l}\text { vôza } \rightarrow \text { G jd. m.r. im. vôz 'zaprežna kola kao mjera } \\
\text { količine tereta' }\end{array}$ \\
\hline Žuta krpa i u ćošku grana & $\begin{array}{l}\text { kr̈pa -> N jd. Ž.r. im. 'komad platna namijenjen određenoj } \\
\text { svrsi' }\end{array}$ \\
\hline
\end{tabular}




\begin{tabular}{|c|c|}
\hline & kr̈pa -> 3. os. jd. gl. kr̈pati 'stavljati zakrpe' \\
\hline \multirow[t]{2}{*}{ Diko moja man' se stari staza } & stârī -> G mn. ž.r. odr. prid. stär 'vremešan' \\
\hline & stârī -> N jd. m.r. im. stârī razg. 'star čovjek' \\
\hline \multirow[t]{2}{*}{ Cura mala volje serežana } & völje -> 3. os. jd. gl. vòljeti 'osjećati naklonost' \\
\hline & völje -> N mn. ž.r. im. völja 'sposobnost duha da što hoće' \\
\hline \multirow[t]{2}{*}{ Garava sam, pa mi je pristalo } & prìstalo -> 3. os. jd. gl. prìstati 'odgovarati' \\
\hline & prìstalo -> N jd. s.r. prid. prìstao 'zgodan, naočit' \\
\hline \multirow[t]{2}{*}{ Kad naredim svoje crne vlase } & nàrēdīm -> 1. os. jd. gl. narédati 'poredati' \\
\hline & nàrēdīm -> 1. os. jd. gl. naréditi 'zapovjediti' \\
\hline \multirow[t]{2}{*}{ Tko naredi, odnili ga vrazi } & nàrēdī -> 3. os. jd. gl. naréditi 'zapovjediti' \\
\hline & nàrēdī -> 3. os. jd. gl. narédati 'poredati' \\
\hline
\end{tabular}

U primjerima dvostiha izdvojeni oblični homonimi (homoforme) različita su značenja te pripadaju uglavnom različitim vrstama riječi (iako su zabilježeni i oni istih vrsta riječi), različita su značenja, ali im je prozodijsko obilježje u navedenome obliku jednako što je vidljivo iz tabličnoga prikaza.

2.5.9.3. Ovjerenost homografa

Tablica 5. Homografi i njihova kategorizacija u rječnicima

\begin{tabular}{|l|l|}
\hline \multirow{2}{*}{ Dijelovi stiha } & Izdvojeni leksem i njegovo značenje \\
\cline { 2 - 2 } & Homograf i njegovo značenje \\
\hline I moja bi kosica kosila & kösica dem. 'od kosa - oruđe' \\
\cline { 2 - 2 } & kòsica 'biljni rod iz porodice zvončića' \\
\hline \multirow{2}{*}{ Što podera popu reverendu } & pöpu 'svećenik' \\
\cline { 2 - 2 } & pòpu 'vrsta glazbe' (samo jd.) \\
\hline \multirow{2}{*}{ Diko moja, moja trešnjo rana naćerat na daću } & dáću 'danak' \\
\cline { 2 - 2 } & dâću 'karmine' \\
\cline { 2 - 2 } & trèšnjo 'plod voćke' \\
\hline Oj inočno, graorasta kôko 'tresidba' & kôko hip. 'od kokoš' \\
\cline { 2 - 2 } & köko 'biljka koja sadrži kokain' \\
\hline
\end{tabular}




\begin{tabular}{|c|c|}
\hline \multirow[t]{2}{*}{ Udovice popišana tura } & tûra (N mn. türovi) 'stražnji dio hlača' \\
\hline & tûra (N mn. túrovi) 'izumrlo divlje govedo' \\
\hline \multirow[t]{2}{*}{ bila lalo ljubiti golema? } & lálo 'tulipan' \\
\hline & lälo 'turski velikaš, dvoranin' \\
\hline \multirow[t]{2}{*}{ Cura sebi para bira } & $\begin{array}{l}\text { pâra 'dva podjednaka predmeta ili osobe koje čine } \\
\text { cjelinu' }\end{array}$ \\
\hline & pâra zast. 'čas, trenutak' \\
\hline \multirow[t]{2}{*}{ Znaš li lolo, što je moja rana? } & rána 'hrana' \\
\hline & räna 'ozljeda' \\
\hline \multirow[t]{2}{*}{ Ljub' me, diko, ako ti je kana } & kána 'namjera' \\
\hline & $\begin{array}{l}\text { käna 'prašak tropske biljke koji se koristi za bojanje } \\
\text { kose' }\end{array}$ \\
\hline \multirow[t]{2}{*}{ ispod jarka da ne vidi majka } & járka 'prokop' \\
\hline & jàrka 'oružje' \\
\hline \multirow[t]{2}{*}{ U inoče noge ko dvi tačke } & täčke 'pritka' \\
\hline & táčke 'vrsta tjestenine s nadjevom' \\
\hline \multirow[t]{2}{*}{ Mila mamo ja bi jela šljiva } & šljîva 'plod voćke' \\
\hline & šljíva 'šljivovica' \\
\hline \multirow[t]{2}{*}{ kobasice $i$ slatke masnice } & masnìce 'kolač od dizanoga tijesta' \\
\hline & màsnice 'modrica' \\
\hline \multirow[t]{2}{*}{ da iskopam raku na sokaku } & räku 'grob' \\
\hline & ràku 'člankonožac' \\
\hline \multirow[t]{2}{*}{ dva za dikom, treće za jedinkom } & jedínkom 'majčin naziv od mila muškome djetetu' \\
\hline & jèdinkom 'zaseban predstavnik neke populacije' \\
\hline \multirow[t]{2}{*}{ ni prečega röda od švalerke } & röda 'obitelj, rodbina' \\
\hline & róda 'vrsta ptice selice' \\
\hline \multirow[t]{2}{*}{ Oj, divojko u vezeni skuta } & skúta 'donji kraj ženske haljine ili suknje' \\
\hline & sküta 'ugrušano mlijeko' \\
\hline \multirow[t]{2}{*}{ moj je lola, ić ćemo do suda } & lóla 'momak, dragi' \\
\hline & lôla od gl. lólati se 'bećariti se' \\
\hline \multirow[t]{2}{*}{ Ide dika u cipela škripa } & $\begin{array}{l}\text { škrïpa 'reski zvuk koji nastaje pri trenju nepodmazanih } \\
\text { mehanizama ili rasušenih drvenih predmeta' }\end{array}$ \\
\hline & škrîpa 'mučilo u srednjem vijeku' \\
\hline
\end{tabular}




\begin{tabular}{|c|c|}
\hline \multirow{2}{*}{$\begin{array}{l}\text { U mene je somot oko vrata } \\
\text { Čim na vrata, ruke oko vrata }\end{array}$} & vrâta 'dio tijela' \\
\hline & vráta $p l$. tantum 'otvor u zidu kroz koji se prolazi' \\
\hline \multirow[t]{2}{*}{ Što će diki šlingana rubina } & rùbina $^{98}$ 'pletena duga košulja ili suknja' \\
\hline & rubína 'dragi kamen crvene boje' \\
\hline \multirow[t]{2}{*}{ Od tog bola nješta biti mora } & bôla 'osjet patnje' \\
\hline & bóla 'hladno piće koje se pripravlja od vina ili čaja' \\
\hline \multirow[t]{2}{*}{ Šićer, kava, to je mora 'rana } & kàva 'crni napitak' \\
\hline & kâva 'kamenolom' \\
\hline \multirow[t]{2}{*}{ Siva mica i za njom đurđica } & mìca 'kapa' \\
\hline & míca hip. 'od mačka' \\
\hline \multirow[t]{2}{*}{ a vi šolje id' te do nevolje } & šölje 99 'posprdni naziv za Šokca' \\
\hline & šólje 'šalica' \\
\hline \multirow[t]{2}{*}{ svud putnica, nemaš obrvica } & pùtnica $^{100}$ 'prljavština ili nakupina znoja na koži' \\
\hline & pûtnica 'žena koja putuje' \\
\hline \multirow[t]{2}{*}{ Oj Vinkovci, ni selo, ni varoš } & vároš reg. 'manji grad' \\
\hline & vâroš 'težački dio u gradu primorskoga tipa' \\
\hline \multirow[t]{2}{*}{ ja ću piti, ti ćeš kurva biti } & kûrva 'nevjerna žena' \\
\hline & kürva 'krivulja, zavoj' \\
\hline \multirow[t]{2}{*}{ Dva su bora kraj dikina dvora } & bôra 'biljni rod četinjača' \\
\hline & bòra 'kemijski element' \\
\hline \multirow[t]{2}{*}{ ge su bile, odnile ih vile } & víle 'mitološko biće' \\
\hline & vïle 'kuća' \\
\hline \multirow[t]{2}{*}{ Drima mi se ovaj cili danak } & dának hip. 'od dan' \\
\hline & dänak 'porez, daća' \\
\hline \multirow[t]{2}{*}{ Šala kraju, a ti dojdi diko } & šála 'nestašluk' \\
\hline & šäla 'zahodska školjka' \\
\hline \multirow[t]{2}{*}{ a ja njemu škatulju patrona } & patróna 'čahura s nabojem i metkom' \\
\hline & patrôna 'zaštitnica' \\
\hline već patrice i križ oko vrata & pâtrice $p l$. tantum 'krunica, čislo' \\
\hline
\end{tabular}

\footnotetext{
${ }^{98}$ Definicija leksema nije zabilježena u VRHJ-u. On navodi leksem rübine ž zb. 'rublje'. Ni ostali je rječnici ne navode kao natuknicu.

${ }^{99}$ Natuknicu je objasnio Janković (1967).

${ }^{100}$ Značenja pod tom natuknicom u VRHJ-u nema niti je navedena u drugim rječnicima. U Rječniku razlika između hrvatskoga i srpskoga jezika Vladimira Brodnjaka (dalje: RRIHSJ) zabilježen je oblik putnjica.
} 


\begin{tabular}{|c|c|}
\hline & patrìce 'kalup iz kojeg se liju matrice' \\
\hline \multirow[t]{2}{*}{ Liju suze, teku ko na pipu } & pípu ${ }^{101}$ 'slavina' \\
\hline & pìpu 'lulu' \\
\hline \multirow[t]{2}{*}{ U'vati me, lolo, oko pasa } & pâsa 'pojas' \\
\hline & pásā 'domaća životinja' \\
\hline \multirow[t]{2}{*}{ ko gospoje tanke u pojasu } & pòjāsu 'struk' \\
\hline & pójāsu 'dubinska riba koštunjača' \\
\hline \multirow[t]{2}{*}{ Ako nema u kase 'iljada } & käse 'blagajna' \\
\hline & kàse 'kundak' \\
\hline \multirow[t]{2}{*}{ kraj kućara limunove sadi } & $\begin{array}{l}\text { kućára }^{102} \text { 'u zadružnim i kućama posebni odjeljci u } \\
\text { kojima žive oženjeni ljudi sa ženama' }\end{array}$ \\
\hline & $\begin{array}{l}\text { küćara 'onaj koji obilazi kuće i nudi kakvu robu na } \\
\text { prodaju' }\end{array}$ \\
\hline \multirow[t]{2}{*}{ što ja nemam ni kola ni konja } & kôlā $p l$. tantum 'vrsta prijevoznog sredstva' \\
\hline & kôla' ${ }^{103}$ 'rod drveća' \\
\hline \multirow[t]{2}{*}{ Nemoj kćeri, čedo ćeš imati } & čèdo 'novorođenče' \\
\hline & čédo žarg. 'četnik' \\
\hline \multirow[t]{2}{*}{ Diko moja, dojdi priko plota } & $\begin{array}{l}\text { plòta (N mn. plòtovi) 'drvena, pletena i sl. ograda koja } \\
\text { omeđuje dvorište' }\end{array}$ \\
\hline & $\begin{array}{l}\text { plòta (N mn. plòti) 'čovječje tijelo u ukupnosti fizičkih } \\
\text { svojstava i putenosti, oprečno duhovnosti' }\end{array}$ \\
\hline \multirow[t]{2}{*}{ to je meni ostalo od babe } & bábe 'otac' \\
\hline & bäbe 'baka' \\
\hline \multirow[t]{2}{*}{ Alaj volim сигicu и сіси } & cìcu 'vrsta tkanine' \\
\hline & cìcu 'dojka' \\
\hline \multirow[t]{2}{*}{ da maršira od mene daleko } & maršíra od gl. maršírati nesvrš. 'stupati' \\
\hline & maršíra od gl. maršírati (koga) $d v$. dati nogu ' \\
\hline Derite se cipelice nove & dèrite se od gl. dèrati 'upotrebom trošiti; rabiti' \\
\hline
\end{tabular}

${ }^{101}$ Leksem u VRHJ-u obilježen je kratkosilaznim naglaskom (pïpa).

${ }_{102}$ Značenja pod tom natuknicom u VRHJ-u nema niti je navedena u drugim rječnicima, no u RRIHSJ-u je zabilježena natuknica pod tim objašnjenjem.

${ }^{103}$ Leksem u Rječniku stranih riječi Bratoljuba Klaića (dalje: RSR) obilježen je kratkosilaznim naglaskom (köla). 


\begin{tabular}{|c|c|}
\hline & dèrite se od gl. dèrati se 'vikati' \\
\hline \multirow[t]{2}{*}{ Trni, diko, na oltaru sveću } & tr̀ni od gl. tr̀nuti 'gasiti' \\
\hline & tŕni od gl. tŕnuti 'biti obuzet trncima' \\
\hline \multirow[t]{2}{*}{ Cilim vikom tužit ću za dikom } & túžit od gl. túžiti nesvrš. 'tugovati' \\
\hline & túžit od gl. túžiti svršs. 'podnijeti tužbu' \\
\hline \multirow[t]{2}{*}{ Sunce sija, pa će i Rusija } & sìja od gl. sìjati 'sjajiti' \\
\hline & $\begin{array}{l}\text { sìja od gl. sìjati 'rukom ili strojem bacati sjeme na zemlju } \\
\text { pripremljenu za sjetvu' }\end{array}$ \\
\hline \multirow[t]{2}{*}{ da se spare, moli tvoje stare } & spâre se od gl. spáriti (se) 'združiti u par' \\
\hline & späre se od gl. späriti (se) 'opariti, opeći parom' \\
\hline \multirow[t]{2}{*}{ Svekrva me pogleda sa strane } & pogléda od gl. poglédati 'osvrtati se na koga/što' \\
\hline & pògleda od gl. pògledati 'kratko uputiti pogled' \\
\hline \multirow[t]{2}{*}{ Ako, diko, večerà ne dojdeš } & večerà pril. 'ove večeri; večeras' \\
\hline & vèčera im. 'večernji objed' \\
\hline \multirow[t]{2}{*}{ Bilo vedro, pa se naoblači } & vëdro pril. 'na vedar način' \\
\hline & vèdro im. 'bačva, kaca' \\
\hline \multirow[t]{2}{*}{ Što će meni bogato pa ludo } & lúdo prid. s.r. 'koje je izvan sebe' \\
\hline & lûdo pril. 'na lud način, kao luđak' \\
\hline \multirow[t]{2}{*}{ Niska čižma, a visoke pete } & nïska prid. ž.r. 'blizu tla' \\
\hline & nìska im. 'ogrlica, lančić' \\
\hline \multirow[t]{2}{*}{ il' umrla il' ostala živa } & žíva prid. ž.r. 'koja živi' \\
\hline & žìva im. 'živo srebro' \\
\hline \multirow[t]{2}{*}{ Sve do lane pjeva pjesme stare } & láne pril. 'prošle godine' \\
\hline & läne im. 'mlado košute ili srne' \\
\hline \multirow[t]{2}{*}{ milo moje, sad ću pjevat' nove } & säd pril. 'u ovo vrijeme' \\
\hline & säd čest. 'riječ koja najavljuje neodređeno oklijevanje' \\
\hline \multirow[t]{2}{*}{ Nisi diko ti u selu jedan } & jèdan br. 'najmanji cijeli broj' \\
\hline & jêdan prid. 'srdit, ljut' \\
\hline \multirow[t]{2}{*}{ Garava mi lola kod topova } & $\begin{array}{l}\text { köd prij. 'označuje da se što nalazi, zbiva ili je u blizini } \\
\text { koga ili čega ili među kim' }\end{array}$ \\
\hline & kôd im. 'sustav ugovorenih znakova; signal' \\
\hline drugi pod pendžerom viko & $\begin{array}{l}\text { pöd prij. 'izriče mjesto kojem se s donje strane tko/što } \\
\text { nalazi' }\end{array}$ \\
\hline
\end{tabular}




\begin{tabular}{|c|c|}
\hline & pöd im. 'površina prostorije po kojoj se hoda' \\
\hline \multirow[t]{2}{*}{ Ne srdi se zbilja, moja diko } & zbïlja pril. 'doista, zaista' \\
\hline & zbílja im. 'stvarnost' \\
\hline \multirow[t]{2}{*}{ i naša je strana patosana } & strána im. 'kraj, predio' \\
\hline & strâna prid. ž.r. 'tuđa' \\
\hline \multirow[t]{2}{*}{ reko j' dragi, da me uzet neće } & ùzet od gl. ùzēti 'vjenčati' \\
\hline & üzēt prid. 'paraliziran' \\
\hline \multirow[t]{2}{*}{ Vedro nebo i široko polje } & širòko prid. s.r. 'prostrano' \\
\hline & širòko im. 'jugo, šilok' \\
\hline \multirow[t]{2}{*}{ dika se na divan opravlja } & dìvan im. 'razgovor' \\
\hline & dîvan prid. 'krasan' \\
\hline \multirow[t]{2}{*}{ Oj divojko, nemoj mene kleti } & klêti od gl. klêti 'psovati' \\
\hline & klêtī prid. 'prokleti' \\
\hline \multirow[t]{2}{*}{ Da ja znadem što je selu krivo } & krîvo pril. 'tako da ne bude pravo, pravedno' \\
\hline & krîvo prid. s.r. 'koje je zakrivljeno' \\
\hline \multirow[t]{2}{*}{ Pit ću, pit ću, dok je u sudiću } & dök vez. 'označuje istodobnost' \\
\hline & dök im. 'plovni ili suhi objekt za dizanje brodova iz vode' \\
\hline \multirow[t]{2}{*}{ kada ljubim mladog sekretara } & kàda vezn. 'izriče vrijeme' \\
\hline & $\begin{array}{l}\text { káda im. hip. 'od kaduna' ili káda im. 'posuda za } \\
\text { kupanje' }\end{array}$ \\
\hline \multirow[t]{2}{*}{ Kaži, curo, pošto ti je cena } & pöšto pril. 'po koju cijenu, po koliko' \\
\hline & $\begin{array}{l}\text { pöšto vezn. 'izriče vrijeme ili uzrok radnje glavne } \\
\text { rečenice' }\end{array}$ \\
\hline \multirow[t]{2}{*}{ Uči diko makar kaku školu } & màkar pril. 'bar, barem' \\
\hline & màkar vezn. 'u dopusnim izrazima' \\
\hline \multirow[t]{2}{*}{ 'Ajde lolo, da se pomirimo } & hàjde uzv. 'za poticanje' \\
\hline & $\begin{array}{l}\text { hàjde čest. 'riječ za dopuštanje prethodne tvrdnje } \\
\text { govornika' }\end{array}$ \\
\hline \multirow[t]{2}{*}{ Kad ti lice od maljila gorko } & górko prid. s.r. 'koje ima okus pelina' \\
\hline & gôrko pril. 'na gorak način' \\
\hline \multirow[t]{2}{*}{ urekla me moja dika stara } & ùrekla od gl. ùreći (što) svršs. (prez. urèčēm) 'baciti urok' \\
\hline & $\begin{array}{l}\text { ùrekla od gl. ùreći (koga) svrš. (prez. ùreknēm) } \\
\text { 'zakazati dogovor' }\end{array}$ \\
\hline
\end{tabular}




\begin{tabular}{|c|c|}
\hline \multirow[t]{2}{*}{ kaži diko, da sam ti valjala } & vàljala od gl. vàljati 'vrijediti' \\
\hline & váljala od gl. váljati 'koturati' \\
\hline \multirow[t]{4}{*}{ Alaj mi se šikuje pomada } & àlāj uzv. 'osjećanja' \\
\hline & àlāj im. 'mnoštvo, masa' \\
\hline & šikuje se od gl. šikati se 'pristaje, dolikuje' \\
\hline & šîkuje od gl. šíkati 'glasati se kao guska kad je ljuta' \\
\hline \multirow[t]{4}{*}{ Blago dolu, di se dvoje volu } & $\begin{array}{l}\text { blägo uzv. 'izražava zadovoljstvo, sreću; izvrsno!, } \\
\text { odlično! }\end{array}$ \\
\hline & $\begin{array}{l}\text { blâgo im. 'velika vrijednost u novcu, zlatu i } \\
\text { dragocjenostima' }\end{array}$ \\
\hline & völu od gl. vòljeti 'osjećati ili iskazivati naklonost' \\
\hline & vòlu im. 'uškopljen mužjak goveda' \\
\hline \multirow[t]{2}{*}{ Oj derane, sunce iza gore } & gòre im. 'planina' \\
\hline & göre pril. 'više od neke ravni' \\
\hline \multirow{2}{*}{$\begin{array}{l}\text { ljubi, diko, kad se lude dadu } \\
\text { Nisam luda, pa sebična biti }\end{array}$} & lüde/a im. 'ublaženo od luđakinja' \\
\hline & lûde/lúda prid. 'koje su/koja je izvan sebe' \\
\hline \multirow[t]{4}{*}{ kasno leči, rano ustajati } & lèći od gl. lëći 'zauzeti vodoravan položaj' \\
\hline & lêći od gl. lêći 'sjediti na jajima dok se mladi ne izlegu' \\
\hline & räno pril. 'u početku dana' \\
\hline & räno im. 'ozljeda' \\
\hline \multirow[t]{2}{*}{ koliko ima na klaviru žica } & žîca im. 'nit, struna' \\
\hline & žìca od gl. žìcati žarg. 'moljakati' \\
\hline \multirow[t]{2}{*}{ Ne boljujem, što me bolja tišti } & bólja im. ekspr. 'bolest' \\
\hline & böljāā prid. ž.r. komp. 'od dobra' \\
\hline \multirow[t]{2}{*}{ mora slušat i gazda i sluga } & môra od gl. mórati 'protiv svoje volje činiti što' \\
\hline & möra im. 'neugodan san' ili móra 'kratki slog' \\
\hline \multirow[t]{2}{*}{ Lolo moja, zumbule rani } & rânī prid. 'koji sazrijeva prije' \\
\hline & räni od gl. räniti 'napraviti ranu' \\
\hline \multirow[t]{2}{*}{ Dika stara priko kola šara } & šâra od gl. šárati pren. 'varati' \\
\hline & šára im. 'motiv (ornament)' \\
\hline \multirow[t]{2}{*}{ igra ko cajger na satu } & İgra od gl. İgrati 'titrati, treperiti' \\
\hline & ìgra im. 'spontana intelektualna tjelesna aktivnost' \\
\hline il' po mraku il' po suncu jarku & jârku prid. 'vruć, vreo' \\
\hline
\end{tabular}




\begin{tabular}{|c|c|}
\hline & járku im. 'prokop, kanal' \\
\hline \multirow[t]{2}{*}{ Puče puška za bosanski' gora } & püče od gl. pücati 'gađati iz vatrenoga oružja' \\
\hline & pûče im. 'narod' \\
\hline \multirow[t]{2}{*}{ pa od zala u šamac upala } & ùpala od gl. ùpasti 'pasti' \\
\hline & ùpala im. 'inflamacija' \\
\hline \multirow[t]{2}{*}{ da se želja srditi počela } & pöčela od gl. pòčēti 'pokrenuti' \\
\hline & počéla im. 'princip' \\
\hline \multirow[t]{2}{*}{ da me kori za svoje imanje } & kòri od gl. kòriti 'grditi' \\
\hline & köri im. 'vanjski dio debla' \\
\hline \multirow[t]{2}{*}{ dika s kora pogledati mora } & kóra im. m.r. 'pjevalište' \\
\hline & köra im. ž.r. 'vanjski dio debla' \\
\hline \multirow[t]{2}{*}{ Moj se dika na mašini šiša } & šîšā od gl. šíšati 'skraćivati kosu' \\
\hline & šiša im. reg. 'boca, staklenka' \\
\hline \multirow[t]{2}{*}{ Alaj volim, kad tambura svira } & tàmbura im. 'trzalački instrument' \\
\hline & tambùra od gl. tambùrati 'svirati tamburu' \\
\hline \multirow[t]{4}{*}{ Vodi tata iz štale Dorata } & $\begin{array}{l}\text { vödī od gl. vòditi 'pomagati komu u hodu ili držeći ga na } \\
\text { vodici' }\end{array}$ \\
\hline & vòdi im. 'tekućina' \\
\hline & täta fam. hip. 'od otac' \\
\hline & tàta 'kradljivac, lopov' \\
\hline \multirow[t]{2}{*}{ u mog dike ancug dunkl plavi } & plâvī prid. 'koji je boje neba' \\
\hline & plávī od gl. pláviti 'bojiti u plavo' \\
\hline \multirow[t]{2}{*}{ Dođi, diko, malo fenta radi } & rädi prij. 'poradi, zaradi' \\
\hline & râdi od gl. ráditi 'obavljati posao' \\
\hline \multirow[t]{2}{*}{ Nisam lipa, samo nemam fleka } & sàmo vezn. 'označava suprotnost ili izuzimanje' \\
\hline & sámo od prid. s.r. 'bez drugih ljudi, bez ikoga' \\
\hline \multirow[t]{2}{*}{ Oj kako je kajsija sazrela } & kàko vezn. 'izriče način' \\
\hline & kàko pril. 'izriče ili pita način vršenja radnje' \\
\hline \multirow[t]{2}{*}{ pa na mene i laju i reže } & réže od gl. réžati 'bijesno govoriti kroza zube' \\
\hline & rèže od gl. rëzati 'oštricom odvajati komade' \\
\hline \multirow[t]{2}{*}{ Šiške moje kako lipo stoje } & stòje od gl. stàjati 'pristajati' \\
\hline & stóje im. žarg. 'stotinjarka' \\
\hline Diko moja, kupi mi sandale & kúpi od gl. kúpiti 'dobiti u vlasništvo plaćanjem' \\
\hline
\end{tabular}




\begin{tabular}{|c|c|}
\hline & küpi od gl. küpiti 'pribirati, skupljati' \\
\hline \multirow[t]{2}{*}{ pa ti kupiš tuđe ostaloće } & küpiš od gl. küpiti 'pribirati, skupljati' \\
\hline & kûpiš od gl. kúpiti 'dobiti u vlasništvo plaćanjem' \\
\hline \multirow[t]{2}{*}{ Slobodjanke fertuniće nižu } & nîžu od gl. nízati 'redati, stavljati jedno za drugim' \\
\hline & nïžu prid. ž.r. 'koja ima malu visinu' \\
\hline \multirow[t]{2}{*}{ Imam suknju, još da mi je rekla } & rékla im. 'kaputić' \\
\hline & rëkla od gl. rëči 'izjaviti' \\
\hline \multirow[t]{2}{*}{ Digni Kajo, kraj od šlingeraja } & krâj im. 'dio oko ruba platna i sl.' \\
\hline & kräj prij. 'u neposrednoj blizini' \\
\hline \multirow[t]{2}{*}{ pod vratom izvezena zlatom } & izvezèna od gl. ìzvēsti 'izraditi vezenjem' \\
\hline & izvèzena od gl. ìzvesti 'vodeći udaljiti' \\
\hline \multirow[t]{2}{*}{ Crna suknja, priljevana svila } & svíla im. 'vrsta tkanine' \\
\hline & svilla od gl. svìti 'saviti što' \\
\hline \multirow[t]{2}{*}{ Crne oči i obrve vrane } & vrâne prid. ž.r. ekspr. 'crne' \\
\hline & vräne im. 'vrsta ptice' \\
\hline \multirow[t]{2}{*}{ te dvi prije da ni jedne nije } & príje im. hip. 'od prijateljica' \\
\hline & $\begin{array}{l}\text { prïje prij. 'da se što događa u vremenu ranije od onoga } \\
\text { što znači riječ na koju se odnosi' }\end{array}$ \\
\hline \multirow[t]{2}{*}{ Alaj prija ima mušterija } & príja im. hip. 'od prijateljica' \\
\hline & prìja od gl. prìjati 'odgovara' \\
\hline \multirow[t]{4}{*}{ Prije dika inoču mi ruži } & $\begin{array}{l}\text { prïje pril. 'dalje u prošlosti u odnosu na trenutak kad se } \\
\text { što zbiva' }\end{array}$ \\
\hline & $\begin{array}{l}\text { prïje prij. 'da se što događa u vremenu ranije od onoga } \\
\text { što znači riječ na koju se odnosi' }\end{array}$ \\
\hline & rûži od gl. rúžiti 'grditi' \\
\hline & rúži im. 'vrsta cvijeta' \\
\hline \multirow[t]{2}{*}{ Mene ružu, nisam ništa kriva } & rûžu od gl. rúžiti 'grditi' \\
\hline & rúžu im. 'vrsta cvijeta' \\
\hline \multirow[t]{2}{*}{ Pivaj, drugo, ja ću ti rožit } & drûgo im. 'prijateljica' \\
\hline & drügo prid. 'različito, drugačije' \\
\hline \multirow[t]{2}{*}{ Teret, tuga, udaje se druga } & drúga im. 'prijateljica' \\
\hline & drügā br. prid. 'koja je po redu za prvom' \\
\hline kaže ala, da sam nevaljala & ála im. 'aždaja, zmaj' \\
\hline
\end{tabular}




\begin{tabular}{|c|c|}
\hline & äla prid. 'šaren, višebojan' \\
\hline \multirow[t]{2}{*}{ jer ćeš dobit čabrenikom } & dòbit od gl. dòbiti 'iskusiti ili trpjeti' \\
\hline & döbit im. 'dobitak, profit' \\
\hline \multirow[t]{2}{*}{ Vetar piri a pargar se širi } & šîri od gl. šíriti 'činiti širim' \\
\hline & šìrī prid. komp. 'koji ima znatniju širinu' \\
\hline \multirow[t]{2}{*}{ da ne idem, kud me srce vuče } & vúče od gl. vûći 'privlačiti' \\
\hline & vûče im. 'sisavac mesožder' ili vüče im. 'tegljenje' \\
\hline \multirow[t]{2}{*}{ Moja lola u kolu egeda } & egèda od gl. egèdati 'svirati, gudjeti' \\
\hline & ègēdā im. 'gusle' \\
\hline \multirow[t]{2}{*}{ da ti dade urlab osam dana } & dána im. 'doba, vrijeme' \\
\hline & dâna prid. trp. ž.r. od gl. däti 'predati' \\
\hline \multirow[t]{2}{*}{ Mene mama i bije i tuče } & túče od gl. tûći 'udarati' \\
\hline & tüče im. 'krupa, grad' \\
\hline \multirow[t]{2}{*}{ Sad se selom telegrami prave } & präve od gl. präviti 'izrađivati, proizvoditi' \\
\hline & prâve prid. ž.r. 'prirodna, postojeća' \\
\hline \multirow[t]{4}{*}{ Liju suze, teku ko na pipu } & lìjū od gl. lìti 'jako teći' \\
\hline & líju im. hip. 'od lisica' \\
\hline & tèkū od gl. tëći 'liti' \\
\hline & téku im. 'bilježnica' \\
\hline \multirow[t]{4}{*}{ nego zemlja koja dobro rodi } & dòbro pril. 'prikladno' \\
\hline & dòbro im. 'posjed' \\
\hline & ròdi od gl. ròditi 'dati plod' \\
\hline & ródi im. 'vrsta ptice selice' \\
\hline \multirow{2}{*}{$\begin{array}{l}\text { volim žene, a curice mene } \\
\text { Mene žene, a diku udaju }\end{array}$} & žène im. 'odrasla osoba ženskog spola' \\
\hline & žène od gl. žèniti 'stupati u brak' \\
\hline \multirow[t]{2}{*}{ već udaju jutra i frtalji } & ùdāju od gl. ùdati 'stupiti u brak' \\
\hline & üdaju im. 'stupanje ženske osobe u brak' \\
\hline \multirow[t]{2}{*}{ Što se ale mojom dikom fale } & fâle od gl. hváliti 'isticati dobra svojstva ili osobine' \\
\hline & fäle od gl. fäliti reg. 'nedostajati, manjkati' \\
\hline \multirow[t]{2}{*}{ Crna kapa i kajiš crveni } & cr̀veni prid. m.r. 'koji je boje krvi' \\
\hline & crvèni od gl. crvèniti 'činiti crvenim' \\
\hline \multirow[t]{2}{*}{ Volim kad me teraje perjaši } & perjáši im. 'oni koji tuku, nasilnici' \\
\hline & pèrjaši od gl. perjášiti ekspr. 'perjati' \\
\hline
\end{tabular}




\begin{tabular}{|c|c|}
\hline \multirow[t]{2}{*}{ a bogati ore na voli rogati } & bògati prid. 'koji ima obilje materijalnih dobara' \\
\hline & bögati čest. 'za pojačavanje onoga što se govori' \\
\hline \multirow[t]{2}{*}{ med nama je zbog drugi ... } & mëd prij. 'među, između' \\
\hline & mêd im. 'sladak gust sok' \\
\hline \multirow[t]{2}{*}{ duge vlase, pa ne daju na se } & dùge prid. ž.r. 'veće dužine' \\
\hline & dúge im. 'pojava na nebu' \\
\hline \multirow[t]{4}{*}{ i levorver, koji šest put pali } & $\begin{array}{l}\text { pût pril. 'u vezi s rednim brojevima pokazuje poredak u } \\
\text { nizu drugih radnji' }\end{array}$ \\
\hline & pût im. 'utaban i utrt dio zemlje' \\
\hline & pâli od gl. páliti 'pucati' \\
\hline & pàli prid. rad. od gl. pàsti 'biti srušen' \\
\hline \multirow[t]{6}{*}{ Mene cure zlobu pored blaga } & cüre im. razg. 'djevojka' \\
\hline & cúre od gl. cúriti 'teći tankim mlazom' \\
\hline & zlòbū od gl. zlòbiti 'htjeti nekom zlo; pakostiti' \\
\hline & zlòbu im. 'pakost, zluradost' \\
\hline & $\begin{array}{l}\text { blâga im. pren.'duhovno, kulturno i drugo dobro, } \\
\text { (dragi)' }\end{array}$ \\
\hline & blága prid. ž.r. 'koja je dobre naravi' \\
\hline \multirow[t]{2}{*}{ oko mene oda zabadava } & ôda od gl. hódati 'kretati se' \\
\hline & óda im. 'forma svečane lirske pjesme' \\
\hline \multirow[t]{2}{*}{ sada cure odaje za momci } & ôdaje od gl. hódati 'kretati se' \\
\hline & òdaje im. 'prostorija, soba' \\
\hline \multirow[t]{2}{*}{ Pita momak svoje cure stare } & pîta od gl. pítati 'ispitivati' \\
\hline & pìta im. 'jelo od naslaganih listova tijesta s nadjevom' \\
\hline \multirow[t]{2}{*}{ Dika mi se nepošteno vlada } & vlâda od gl. vládati 'ponašati (se)' \\
\hline & vláda im. 'najviši organ izvršne vlasti neke države' \\
\hline \multirow[t]{2}{*}{ metla šila ne bil se nabila } & mëtla od gl. mètnuti 'staviti, smjestiti' \\
\hline & mètla im. 'kućansko pomagalo za čišćenje poda' \\
\hline \multirow[t]{2}{*}{ Zlatan prsten, u njem kamen žuti } & žûti odr. prid. 'koji je boje limuna' \\
\hline & žúti od gl. žútiti 'bojiti žutom bojom' \\
\hline \multirow[t]{2}{*}{ Ge sam svoje školovala dere } & dére im. 'deran, neodgojen dječak' \\
\hline & dère od gl. dèrati 'namjerno trgati' \\
\hline za nedilju pegla mi rubinu & pêgla od gl. péglati razg. 'glačati' \\
\hline
\end{tabular}




\begin{tabular}{|c|c|}
\hline & pégla ${ }^{104}$ im. reg. 'glačalo' \\
\hline \multirow[t]{2}{*}{ Tri me lole priko kola glede } & gléde od gl. glèdati 'promatrati' \\
\hline & glëde pril. arh. 'što se tiče' \\
\hline \multirow[t]{2}{*}{ Moga diku sulferinke mitu } & mîtū od gl. mítiti 'davati mito kome' \\
\hline & mítu im. 'novac koji se daje kriomice' \\
\hline \multirow[t]{4}{*}{ kad u blato, takija zapadu } & käd vezn. 'izriče vrijeme' \\
\hline & kâd im. ekspr. 'mirisan dim' \\
\hline & zapádu od gl. zàpasti 'pasti' \\
\hline & zâpadu im. 'strana svijeta' \\
\hline \multirow[t]{2}{*}{ Žuta krpa i u ćošku grana } & grána im. 'dio stabla koji raste iz debla' \\
\hline & gràna od gl. grànati (se) 'širiti grane' \\
\hline \multirow[t]{2}{*}{ Blago ljubi, kad ju jedan ljubi } & ljúbi im. arh. knjiš. 'voljena ženska osoba' \\
\hline & ljûbi od gl. ljúbiti 'cjelivati' \\
\hline \multirow[t]{2}{*}{ Vidiš diko onu zvizdu tanku } & tânku prid. ž.r. pren. 'koja je malena' \\
\hline & tànku im. 'japanski pjesnički oblik' \\
\hline \multirow[t]{2}{*}{ Jadan kuka, ranita mu ruka } & kükā od gl. kükati 'tužiti se' \\
\hline & küka im. 'klin ili šipka zavrnuta na kraju' \\
\hline \multirow[t]{2}{*}{ Moja dika nit' ore nit' zubi } & zúbī od gl. zúbiti' ${ }^{105}$ 'usitnjavati zemlju' \\
\hline & $\begin{array}{l}\text { zûbi im. 'jedna od bjeličastih izraslina koštanoga tkiva u } \\
\text { čeljusti presvučenih caklinom' }\end{array}$ \\
\hline \multirow{2}{*}{$\begin{array}{l}\text { men' se mladu u'vatit ne dadu } \\
\text { bi rada, da mu budem mlada }\end{array}$} & mládu/a prid. ž.r. 'koja nije proživjela mnogo vremena' \\
\hline & mlâdu/a im. 'djevojka na dan vjenčanja' \\
\hline \multirow[t]{2}{*}{ Vidjela sam moga dike stanje } & stánje im. 'imanje' \\
\hline & stânje od gl. stánjiti 'učiniti tankim' \\
\hline \multirow[t]{2}{*}{ a u džepu nema ni filira } & filíra im. 'austrougarski kovani novac' \\
\hline & fîlira od gl. filíratio ${ }^{106}$ 'plesti mrežu' \\
\hline \multirow[t]{2}{*}{ U mog dike, al se obraz žari } & žârī od gl. žáriti 'jako grijati' \\
\hline & žári im. razg. 'kopriva' \\
\hline \multirow[t]{2}{*}{ Volio me, a sad se brani } & brânī od gl. brániti 'opravdavati se' \\
\hline & bráni im. 'pregrada na vodotoku' \\
\hline
\end{tabular}

${ }^{104}$ U VRHJ-u ta natuknica ima dugosilazni naglasak.

105 Te natuknice u VRHJ-u nema niti je navedena u drugim rječnicima.

${ }^{106}$ Natuknica nije zabilježena u VRHJ-u. 


\begin{tabular}{|c|c|}
\hline \multirow[t]{4}{*}{ medu puca di mi srce kuca } & $\begin{array}{l}\text { mèđu prij. 's imenskom riječju u akuzativu znači } \\
\text { dospijevanje' }\end{array}$ \\
\hline & mèđu im. 'granica između dvaju imanja' \\
\hline & püca im. 'dugme' \\
\hline & pùcā od gl. pücati 'gađati iz vatrenoga oružja' \\
\hline \multirow[t]{4}{*}{ Misli selo, što j' kod mene prelo } & mìsli od gl. mïsliti 'razmišljati o kome ili o čemu' \\
\hline & mîsli im. 'proizvod razmišljanja' \\
\hline & prélo im. 'večernji sastanak na selu' \\
\hline & prëlo prid. rad. od gl. prèsti 'upredajući praviti niti' \\
\hline \multirow[t]{2}{*}{ Stani, lolo, u pola birtije } & pöla pril. 'polovina čega' \\
\hline & póla im. zast. 'polovica' \\
\hline
\end{tabular}

Navedeni primjeri u tablici jasno pokazuju kako je broj homografa koji pripadaju istoj vrsti riječi daleko manje zastupljen nego onaj broj homografa koji pripadaju različitim leksičkogramatičkim razredima. Primjerice, kod ovih prvih u odnosu leksema tur razlikujemo različite nominative množine (türovi i túrovi), plot (plòtovi i plòti). U odnosu leksema bor razlikujemo različite genitive jednine (bôra i bòra), a neke imenice u tom odnosu imaju samo jedninu (pop) dok leksemi kola i kola imaju iste sklonidbe, ali se leksem koji označava prijevozno sredstvo razlikuje po obliku za genitiv množine (kôlā). Odnos leksema par i par zanimljiv je zbog toga što imaju jednaku paradigmu, prozodiju, pripadaju istoj vrsti riječi, ali ih ne možemo smatrati homonimima jer su to riječi iz dvaju razdoblja. Ona koja znači 'čas, trenutak' zastarjelica je.

Kod glagola maršírati, túžiti uočava se različit vid ili su oni kao kod glagola dèrati (što) i dèrati se različiti po predmetu radnje od koji je jedan povratan. Kod glagola ùreći (što) 'baciti urok' prezent ima oblik urèčēm, dok kod drugog glagola ùreći (koga) 'zakazati dogovor' prezent glasi ùreknēm te zbog toga navedeni odnosi leksema nikako ne mogu biti homonimi nego isključivo homografi. 
2.5.9.4. Ovjerenost homofona

Tablica 6. Homofoni i njihova kategorizacija u rječnicima

\begin{tabular}{|c|c|c|}
\hline Dijelovi stiha & $\begin{array}{l}\text { Izdvojeni leksem i njegovo } \\
\text { značenje }\end{array}$ & Homofon i njegovo značenje \\
\hline pa kraj dvora prošpanciraj & $\begin{array}{l}\text { dvóra -> G jd. im. dvor } \\
\text { 'dvorište' }\end{array}$ & $\begin{array}{l}\text { Dvóra -> G jd. im. Dvor } \\
\text { 'naselje u J Banovini' }\end{array}$ \\
\hline Izić neće, ključ sam izgubila & $\begin{array}{l}\text { kljûč } \rightarrow \text { A jd. im. ključ } \\
\text { 'predmet za zaključavanje i } \\
\text { otključavanje brava' }\end{array}$ & $\begin{array}{l}\text { Kljûč -> A jd. im. Ključ } \\
\text { 'naselje u blizini Novog } \\
\text { Marofa' }\end{array}$ \\
\hline Komšijnice, dodaj mi vodice & $\begin{array}{l}\text { vòdice -> A jd. im. vòda hip. } \\
\text { 'tekućina bez boje, okusa i } \\
\text { mirisa' }\end{array}$ & $\begin{array}{l}\text { Vòdice -> A jd. im. Vodice } \\
\text { 'naselje u blizini Šibenika' }\end{array}$ \\
\hline Žuta krpa i u ćošku grana & $\begin{array}{l}\text { grána -> N jd. im. grana 'dio } \\
\text { stabla koji raste iz debla' }\end{array}$ & $\begin{array}{l}\text { Grána -> N jd. im. Grana } \\
\text { 'naselje blizu Novog Marofa' }\end{array}$ \\
\hline Oj irošu, da si u Varošu & $\begin{array}{l}\text { Vârošu }->\text { L jd. im. Varoš } \\
\text { 'mjesto } \quad \text { u } \quad \text { okolici } \\
\text { Slavonskoga Broda' }\end{array}$ & $\begin{array}{l}\text { vârošu -> L jd. im. varoš im. } \\
\text { reg. 'težački dio u gradu } \\
\text { primorskoga tipa' }\end{array}$ \\
\hline U Otoku škola i patrola & $\begin{array}{l}\text { Òtoku -> L jd. im. Otok } \\
\text { 'naselje u blizini Vinkovaca' }\end{array}$ & $\begin{array}{l}\text { òtoku } \rightarrow \text { L jd. im. } \\
\text { 'kopno okruženo } \\
\text { strana vodom' }\end{array}$ \\
\hline slađi su u snu već na javi & $\begin{array}{l}\text { jávi } \rightarrow \text { L jd. im. java } \\
\text { 'stvarnost, zbilja' }\end{array}$ & $\begin{array}{l}\text { Jávi -> L jd. im. Java 'otok u } \\
\text { Indoneziji' }\end{array}$ \\
\hline U dragana moja burma mala & $\begin{array}{l}\text { bûrma -> N jd. im. burma } \\
\text { 'zaručnički ili vjenčani prsten' }\end{array}$ & $\begin{array}{l}\text { Bûrma -> N jd. im. Burma } \\
\text { 'ime države Mianmar' }\end{array}$ \\
\hline Siva mica i za njom đurdica & $\begin{array}{l}\text { đùrđica -> N jd. im. đurđica } \\
\text { 'vrsta biljke' }\end{array}$ & $\begin{array}{l}\text { Đùrđica } \rightarrow \mathrm{N} \text { jd. im. } \\
\text { Đurđica 'vlastito ime' }\end{array}$ \\
\hline Cvala ruža u bilom lavoru & $\begin{array}{l}\text { rúža -> N jd. im. ruža 'vrsta } \\
\text { cvijeta' }\end{array}$ & $\begin{array}{l}\text { Rúža } \rightarrow \mathrm{N} \text { jd. im. Ruža } \\
\text { 'vlastito ime' }\end{array}$ \\
\hline Rascvali se od ružice pupci & $\begin{array}{l}\text { rüžice }->\mathrm{G} \text { jd. im. ružica } \\
\text { hip. 'od ruža' }\end{array}$ & $\begin{array}{l}\text { Rüžice -> G jd. im. Ružica } \\
\text { 'vlastito ime' }\end{array}$ \\
\hline
\end{tabular}




\begin{tabular}{|l|l|l|}
\hline Podero sam i čizme i sare & $\begin{array}{l}\text { sáre -> N mn. im. sara 'gornji } \\
\text { dio čizme koji obuva list } \\
\text { noge' }\end{array}$ & $\begin{array}{l}\text { Sáre -> G jd. im. Sara } \\
\text { 'vlastito ime' }\end{array}$ \\
\hline baš kod one curetine Jele & $\begin{array}{l}\text { Jéle -> G jd. im. Jela 'vlastito } \\
\text { ime' }\end{array}$ & $\begin{array}{l}\text { jéle -> G jd. im. jela } \\
\text { 'crnogorično stablo' }\end{array}$ \\
\hline Dugi dani, a komisi mali & $\begin{array}{l}\text { mâli -> N mn. prid. malen } \\
\text { 'koji ima male mjere' }\end{array}$ & $\begin{array}{l}\text { Mâli -> N jd. im. Mali } \\
\text { 'država u SZ Africi' }\end{array}$ \\
\hline Mog milana kosa nakudrana & $\begin{array}{l}\text { mìlana -> G jd. prid. mio } \\
\text { 'drag, umiljat' }\end{array}$ & $\begin{array}{l}\text { Mìlana }->\text { G jd. im. Milan } \\
\text { 'vlastito ime' }\end{array}$ \\
\hline Nije mene rodila Ciganka & $\begin{array}{l}\text { Cìgānka -> N jd. im. } \\
\text { Ciganka 'Romkinja' }\end{array}$ & $\begin{array}{l}\text { cìgānka -> N jd. im. ciganka } \\
\text { 'lastavica' }\end{array}$ \\
\hline dat ću mojoj loli da se keri & $\begin{array}{l}\text { [däću] -> 1. os. jd. gl. dati } \\
\text { 'predati' }\end{array}$ & $\begin{array}{l}\text { däću -> A jd. žr. im. daća } \\
\text { 'vila, ljetnikovac' }\end{array}$ \\
\hline
\end{tabular}

Iz tabličnoga prikaza uočava se kako je relativno malen broj istozvučnica, a one koje se pojavljuju uglavnom pripadaju istoj vrsti riječi i to su najčešće odnosi među imenicama. No, iz primjera je vidljivo kako se u homofonskome odnosu mogu naći i pridjev i imenica poput mali i Mali, milana i Milana te glagol i imenica dat ću i daću koji se jednako izgovaraju u određenome obliku kao što je vidljivo iz primjera u tablici.

Analizirajući deseteračke dvostihe, uočeno je i nekoliko primjera koji djeluju homofonima, ali uvidom u njihovu naglasnu strukturu otklonjena je svaka sumnja da je tu riječ o istozvučnicama bez obzira što se njihova izrazna različitost očituje kroz veliko i malo slovo kao kod primjera u tablici. To su primjeri: prëko prijedlog i Prêko 'naselje na SI strani otoka Ugljana', drâgo pridjev 'voljeno, cijenjeno' i Drágo 'vlastito ime', Réza 'vlastito ime' i rèza 'zasun, kračun', Péro 'vlastito ime' i pèro 'naprava za pisanje' te leksemi vlâsi 'niti kose' i Vläsi 'stočari'. 


\subsection{Polisemija u deseteračkim dvostisima}

Polisemija ili višeznačnost pojava je u jeziku koja nastaje različitim načinima; primjerice posuđivanjem, tvorbom novih riječi ili proširivanjem značenja postojeće riječi ${ }^{107}$. Nužno je primijetiti da zbog određenih razloga tijekom povijesti dolazi do kontakta ${ }^{108}$ dvaju ili više jezika u kojem je jedan uvijek dominantniji u odnosu na drugi te na taj način vrši na njega određeni manji ili veći utjecaj. To je živući proces i njega se ne može dokinuti već mu se treba što bolje prilagoditi. Višeznačnost može nastati i tvorbom novih riječi uslijed imenovanja novonastalih pojava i promjena ili proširivanjem značenja postojećoj riječi metaforom ${ }^{109}$ ili metonimijom pri čemu ona dobiva novo značenje, tzv. preneseno značenje. Jesu li to svi načini nastanka polisemije ili je posrijedi zabilježen i neki novi način, cilj je ovoga rada istražiti, kao $\mathrm{i}$ ispitati primat najdominantnijeg načina postanka polisemije, odnose osnovnoga i izvedenoga značenja leksema ${ }^{110}$, zastupljenost pojedinoga zabilježenog značenja leksema u deseteračkim dvostisima, zašto novi kontekst i daje li novo značenje postojećim leksemima te koja je svrha pojavnosti novih značenja i ostanka u jeziku deseteračkih dvostiha.

\subsubsection{Polisemija ili višeznačnost}

Dok se lingvisti uglavnom spore oko definiranja pojma riječi, leksema, značenja, uporabe riječi, tumačenja prirode jezičnoga znaka, sinonimije, homonimije i sl., definicija pojma polisemije $e^{111}$ danas je uglavnom prihvaćena kao jezična pojava višeznačnosti u

\footnotetext{
${ }^{107}$ Hudeček, Mihaljević (1997: 52) navode još i analogiju, specijalizaciju riječi općega jezika, pučku etimologiju, reinterpretaciju homonima.

${ }^{108}$ Iako je ona još uvijek aktualna i nije u potpunosti iscrpljena, o toj su temi pisali i pišu brojni autori poput Filipovića (1986), Sočanac (2004), Vukomanović (1979), Weinreich (1953) i dr.

${ }^{109}$ O problemu metaforizacije više u Mihaljević (2007), Mihaljević-Šarić (1996), Štambuk (2002).

$110 \mathrm{O}$ problemu obostranoga nejednakog preslikavanja hrvatskih naziva i posuđenica, u njezinome slučaju anglizama, govori Mihaljević (2007: 71-73). No taj bi se aspekt mogao primijeniti na svaki odnos unutar kojeg se promatra hrvatska riječ i posuđenica bilo kojeg drugoga jezika. Naime kako ona navodi: „U idealnome bi nazivlju jedan pojam odgovarao jednom i samo jednom nazivu, a jedan bi naziv odgovarao jednom i samo jednom pojmu. pojam $\rightarrow$ naziv naziv $\rightarrow$ pojam pojam $\leftrightarrow$ naziv. "No, nadalje zaključuje kako je: ,jasno da je takvo idealno nazivlje nemoguće, da unutar svakog jezika postoji i istoznačnost i višeznačnost te neistovrijednost (nepreklapanje) hrvatskih i stranih naziva. " Kao primjer navodi engl. riječ information koja u našem jeziku ima čak tri naziva; obavijest, podatak, informacija ovisno o upotrebi i kontekstu te opisuje lekseme sličica i label unutar kojih promatra odnose istovrijednosti i neistovrijednosti među hrvatskim i engleskim nazivima te odnose sinonimije i polisemije unutar svakoga od tih jezika dolazeći do zaključka kako je shema, u kojoj se isprepliću odnosi istovrijednosti, istoznačnosti i višeznačnosti, složena te „koliko je stvarno stanje udaljeno od idealnog zahtjeva za istovrijednošću hrvatskoga i engleskoga naziva, za ukidanjem istoznačnosti (sinonimije) i višeznačnosti (polisemije). Pri normiranju naziva trebalo bi prvo napraviti svojevrsnu »inventuru «, utvrditi koji hrvatski nazivi odgovaraju kojim engleskim nazivima i u kojim značenjima te odgovara li istome nazivu još koji engleski naziv." ${ }^{111}$ Hrvatski enciklopedijski rječnik (2002: 983) i Anić (2003: 1088) definiraju polisemiju kao mijenjanje značenja riječi u vremenu, promjenu značenja kao dijakronijsku pojavu u jeziku, kao višeznačnost, a Simeon (1969, II. sv.: 83) osim što ju definira sposobnošću riječi da ima različita značenja, navodi da „riječi, svezane polisemijom,
} 
sustavu $^{112}$ koja je nastala povijesnim razvojem jezika jezičnom evolucijom te se manifestira kao sinkronijski fenomen. Lingvisti se slažu da se polisemija može proučavati ${ }^{113}$ sinkronijski, u danom trenutku ili dijakronijski, kroz vrijeme. No, sinkronijska i dijakronijska analiza trebaju biti isprepletene jer se sinkronijskom analizom samo uzima u obzir zatečena stanja dok dijakronijska analiza ima zadaću rekonstruirati nastanak, opisati odnos, svezu i motiviranost među pojedinim značenjskim nijansama. ${ }^{114}$

U polisemiji se oslikava složenost semantičke strukture jednog leksema i u jezičnom je sustavu veoma raširena. Stoga u semantičkim istraživanjima po Petrović (2004: 76) trebaju biti „uvijek prisutna dva osnovna pristupa koja su ujedno i polazišta istraživanjima i uporište teorijskim postavkama u opisu semantičkih odnosa: prva je paradigmatska razina na kojoj se izučavaju leksemi i odnosi među leksemima, odnosno opis značenja pojedinih leksema, a druga je sintagmatska razina na kojoj se izučava funkcioniranje leksema u kontekstu i odnos leksema prema drugim jedinicama s kojima se u kontekstu pojavljuje. ${ }^{. e}$

Polisemiju nazivamo i višeznačnošću jer obuhvaća riječi kod kojih postoji asimetričan odnos izraza i sadržaja, tj. njihovom izrazu pridružena su najmanje dva ili više sadržaja, ili

predstavljaju slučajeve promjene vrste značenja jedne te iste riječi, za razliku od homonimije, u kojoj postoji zvukovno podudaranje različitih riječi.e

Raffaelli (2009: 57) polisemiju tumači kao „odraz enciklopedijskih podataka, tj. podataka znanja o svijetu prenesenih i organiziranih tako da postaju značenjski podaci, odnosno dio jezične strukture. Polisemija je jezična pojavnost kojom se pokazuje uvjetovanost i međusobna povezanost konceptnih i jezičnih struktura."

${ }_{112}$ Da tome nije uvijek tako bilo, napominje i Raffaelli (2007: 136) ističući kako je „Jedno od temeljnih pitanja koje se proteže kroz različita lingvistička razdoblja i škole jest koliko je polisemija leksička kategorija dijelom sustava, a koliko je uvjetovana kontekstom, uporabom leksema." Navodi i različita stajališta strukturalističkih lingvista o istoj problematici, npr. E. Coseriua (2000) (Polisemija je izvanjezična pojavnost koja narušava unutrašnji red jezičnoga sustava), S. Ullmana (1969 i 1983) (Svjesno zapostavlja sve vidove strukturiranja polisemnih leksema koji su uvjetovani kontekstom ili jezičnom uporabom. Uporabom uvjetovane pomake $u$ značenju ili značenjske nijanse definira kao ključni izvor nastanku polisemije, ali ih isključuje iz lingvističkoga opisa jer ne pripadaju jezičnome sustavu, već uporabi, tj. govoru), E. Benveniste (1966) (Značenjske su nijanse ključni i nezanemariv funkcionalni čimbenik polisemnih struktura. Polisemni su leksemi dijelom jezičnog sustava bivajući neprestano pod utjecajem uporabe jezika i kontekstualnih okruženja u kojima se pojavljuju. Svaka uporaba polisemnog leksema, svako novo kontekstualno okruženje utječe na nijansiranje postojećih značenja stvarajući pomake u značenju, odnosno značenjske nijanse koje su iz strukturalističkoga kuta gledanja uporabno, odnosno komunikacijski uvjetovane), te neka suvremenija tumačenja, bliskima formalnim pristupima u semantici koja polisemiju objašnjavaju „kao kontekstualno uvjetovana pojavnost, pri čemu se podrazumijeva da svaka nova uporaba leksema stvara novo značenje." Autorica ovo potonje smatra netočnim te pojašnjava da polisemi moraju posjedovati ,strukturalno stabilni dio koji je dio jezičnoga sustava i konvencionalnog znanja govornika, koji omogućuje uspješnu komunikaciju. Oni su istovremeno uvjetovani uporabom i kontekstom. .e

${ }^{113}$ Raffaelli (2009: 58) predlaže tri pristupa proučavanja polisemije; proučavanje polisemije kao višeznačenjske strukture unutar koje su značenja međusobno povezana na temelju kognitivnih procesa kao što su metafora, metonimija, generalizacija i specifikacija; proučavanje polisemije kao zrakasto organizirane strukture po principu rodbinske sličnosti s prototipnim značenjem kao središtem strukture oko kojega se organiziraju njemu više ili manje bliska značenja i značenjske nijanse, i proučavanje polisemije kao principa kategorizacije.

114 Tijekom jezičnog razvoja kao rezultat djelovanja različitih mehanizama nastaje određeno tipično značenje leksema. No, kako bilježi Raffaelli (2009: 61-67) „Dijakronijska dinamika određenoga polisemnog leksema može dovesti do toga da metaforičko značenje postane tipično značenje u sinkronijskome trenutku, a da konkretna značenja (koja su dijakronijski utemeljenija od apstraktnih značenja) mogu postati strukturno rubna.e" 
semantem, tj. „kompleks značenja koja su u međusobnoj svezi (Melvinger 1984: 26).“ Tafra' ${ }^{115}$ (1986: 387) u analizi polisemije značenjsku jedinicu naziva polisemom navodeći da se on „sastoji od dva ili više semema, koji su u semantičkoj intersekciji. Naime, osim distinktivnih semova svi sememi sadrže najmanje jedan integralni sem. "e Točnije pojašnjava kako se polisemem kao skup sastoji od semema kao podskupova, a oni se pak sastoje od semova. Nadalje tumači da ,svi podskupovi imaju najmanje jedan zajednički element““.

Jezični se znak sastoji od jednoga označioca i jednoga označenika, označenoga, tj. jednoga izraza i jednoga sadržaja i to je uglavnom tako, ali postoje i određena odstupanja ${ }^{116}$ od toga koja dovode do viđenja tih jezičnih pojava jezičnim anomalijama ${ }^{117}$. Hudeček, Mihaljević (2009: 167) navode kako ,,jedan označilac ne mora nužno uvijek biti pridružen samo jednom označeniku, kao što ni jedan označenik ne mora uvijek imati samo jedan označilac." Krongauz (2001: 148) tumači da: „Za razliku od mnogih drugih znakovnih sustava, u prirodnom jeziku znakovi mogu imati više od jednog značenja. Drukčije govoreći, u jeziku postoje skupovi jednostavnih znakova, koji se podudaraju po formi, ali se razlikuju sadržajem. Neki od tih jednostavnih znakova mogu se udružiti u okvirima jednoga složenog znaka, a neki ne mogu. U leksikografiji se za uspoređivanje složenih i jednostavnih znakova rabe termini leksem i leksičko-semantička varijanta. Prema tome, različite leksičko-semantičke varijante s jednakom formom mogu uspostaviti odnos s jednim leksemom (polisemija) ili različitim leksemima (homonimija). "e Kad se to obostrano jednoznačno povezivanje označenika i označioca prekrši, dolazi ili do višeznačnosti (homonimije i polisemije) ili istoznačnosti (sinonimije).

Polisemija, kao i homonimija i sinonimija rezultat su povijesnoga razvoja jezika, a često ih se obilježava jezičnim pojavama koje narušavaju "zakon znaka". Ako se prihvati semiološki, znakovni karakter jezika, onda se jezična djelatnost, tj. jezik tumači dihotomijom: jezik (sustav znakova) / govor (njegova realizacija), odnosno riječ se treba promatrati kao jezični znak, kako kaže Tafra (1986: 382): „in potentia i in actu, kao sredstvo nominacije, ali i kao ostvaraj u govoru. $^{\text {ee }}$ Tafra (nav. dj.: 382-383) nadalje navodi da ,kad to ne bismo priznali, problema homonimije, sinonimije ili polisemije ne bi bilo jer je semantička aktualizacija nekog leksema jednoznačna." To pak znači da se u govornome procesu sudionika komunikacije uvijek

\footnotetext{
115 Tafra daje odličan grafički prikaz polisemije uspoređujući je s homonima te zaključuje kako kod potonjih nema ni jednog zajedničkog elementa u značenju. Često se polisemija i homonimija isprepliću jer se i najveći problem pojavljuje upravo u razgraničavanju polisemije i homonimije jer je teoretski nemoguće povući oštru granicu između polisemije i homonimije, ,granicu koja određuje da li se različita značenja svode pod jednu ili pod više natuknica (1986: 386). ${ }^{\text {e }}$

116 Ta odstupanja obično lingvisti nazivaju patološkim pojavama ili jezičnim anomalijama. Više u Gilliéron (1915).

117 Petrović (2004: 76) višeznačnost ne smatra poremećajem u jezičnome sustavu, nego znakom ,'zdravlja' u svakome jeziku, jer pridonosi jezičnoj ekonomiji i omogućuje uporabu jezika kao ekonomičnog, gipkog sustava osjetljivog na kontekst kojim se priopćuje višestrukost i raznolikost ljudskih spoznaja."
} 
aktualizira samo jedno od značenja, tj. do semantičkih konflikata ne dolazi jer se oni razrješavaju kontekstom ${ }^{118}$. Primjerice u slučaju sinonimije (istoznačnosti) kao jezične pojave u kojoj više jezičnih znakova upućuje na istoga referenta, to je najbolje vidljivo. Sinonimi su uvijek zamjenjivi, a sinonimne semantičke razlike realiziraju se unutar konteksta. Kod homonimije kao jezične pojave u kojoj više jezičnih znakova upućuje na različite referente imamo potpunu ovisnost o kontekstu čiji se možebitni konflikti razrješavaju na nivou sintagme, rečenice ili diskursa. Homonimi su međusobno isključivi. Polisemem čini semantička struktura jednoga leksema koja je složena. Značenja polisemičkih riječi ovise o kontekstima u kojima se nalaze, tj. u različitim kontekstima one imaju različito značenje jer dijakronijski gledano polisemija nastaje proširivanjem denotativnoga značenja, odnosno metaforičkim i metonimijskim prijenosom značenja. No, to pak ne izaziva smetnje u jezičnoj komunikaciji jer se u govoru ostvaruje samo jedan semem polisemične riječi te je time kako kaže Giro (1975: 33) „višesmislenost polisemnog znaka ukinuta kontekstom, u jednoj određenoj poruci znak uglavnom ima jedan smisao." To potvrđuje i Raffaelli (2007: 137) navodeći kako „govornici imaju usustavljeno znanje o strukturi polisemnih leksema. Polisemi u komunikaciji ne predstavljaju poteškoće jer govornik uvijek zna koje se značenje ostvaruje u konkretnom kontekstualnom okruženju. "e

Iako je polisemija veoma raširena i njezina je uporaba u jezičnoj komunikaciji neproblematična, polisemija najviše smeta pri prevođenju ${ }^{119}$ jer zavisi od konteksta, starosti riječi i učestalosti uporabe polisemične riječi, a najviše prijepora izaziva pri razgraničavanju od homonimije. O potonjem više u daljnjem tekstu.

Tafra (1986: 387) zaključuje kako „semantički razvoj riječi pokazuje da se sa starošću

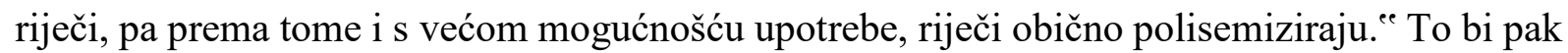
značilo da novi / stari konteksti iz deseteračkih dvostiha otvaraju mogućnost novim značenjima i proširivanju značenja polisemičkih riječi. No, prije samoga navođenja i analize polisemičkih riječi bitno je prvo postaviti jasne granice polisemije i homonimije te odgovoriti na pitanje što je jedno, a što više, odnosno kad je sadržaj jezičnoga znaka monosemičan (jednoznačan), a kada polisemičan (višeznačan). Nadalje, potrebno je razlikovati pripada li više značenja jednoj

118 „U komunikacijskom kontekstu postoji i izvanjezična zalihost koja omogućava normalno odvijanje komunikacije. Ako i dođe do nesporazuma, riješit će ga dodatna obavijest (makrokontekst). Ambigvitet poruke može se izbjeći konvencijom, a postoje i rješenja koja jezik sam pronalazi (arhaizacija jedne riječi i njezino potpuno gubljenje iz leksičkog inventara, promjena roda, divergentni fonetski razvoj fonetski jednako oblikovanih riječi i sl.) (Tafra 1986: 383-384).“

${ }^{119}$ Više u Mihaljević (2007: 73). 
jezičnoj jedinici ili dvjema, tj. jesu li značenja nekoga označioca međusobno nesrodna te u kolikoj mjeri.

\subsubsection{Granice polisemije}

Kako utvrditi jednoznačnost ${ }^{120}$ ili višeznačnost jezičnoga znaka $^{121}$, postaviti jasnu granicu te razgraničiti polisemiju i homonimiju, utvrditi razvoj polisemične strukture, zadatak je koji postavlja izazove istraživačima polisemije ${ }^{122}$. Brojni su prijepori oko navedenih problema, no ono što se jasno može reći jest da oštre granice između homonimije i polisemije nema. Obje su pojave nastale povijesnim razvojem jezika i teško je odrediti kad se različita značenja svode pod jednu ili više natuknica. Problem nastaje i zbog različitoga tumačenja i definiranja homonima i homonimije koja se izjednačuje i s homografijom i s homofonijom ${ }^{123}$. To dokazuju i brojni rječnici koji su u obradi tim pojavama pristupili povodeći se za određenim kriterijima $^{124}$ što spominju i Dešić (1982), Tafra $(1986,2016)$ i Hudeček i Mihaljević (1997, 2009).

Homonimi nastaju jezičnim posuđivanjem, tvorbom riječi, kao posljedica glasovnih promjena ili raspadom polisemije, a Tafra (1986: 388) navodi i nastanak fonetskom

\footnotetext{
${ }^{120}$ Gortan-Premk (1997: 38) opisuje da su ,jednoznačne, monosemantičke samo specijalne reči, kao termini (amper), zatim reči kao bicikl, sako, intervju, koje su slične terminima, kao prva, ili su tuđice, semantički još neadaptirane, kao druge. Monosemantičnost termina (dok su termini) proističe iz konvencionalnosti nominacije u terminološkim, i uopšte u zatvorenim leksičkim sistemima. Monosemantičnost tuđica proističe iz osobenosti njihovog semantičkog sadržaja; naime tuđice ulaze u jezik kao nominacione jedinice sa semantičkim sadržajem u kome je izražena pojmovna vrednost, dok ostali elementi značenja gotovo izostaju; a to, dalje, ima za posledicu znatno umanjenu sposobnost i polisemantičke i derivacione disperzije.e

Melvinger (1984: 27) ističe da „,u leksičko - semantičkom jezičnom sustavu jednom formativu može biti pridružen samo jedan semem tako da taj formativ uvijek, u bilo kojem kontekstu, ima isto značenje. Riječi kod kojih postoji ovakav simetrični odnos izraza i sadržaja nazivaju se jednoznačnim ili monosemičkim riječima. Ni u jednom jeziku takvih riječi nema mnogo. Najčešće su to termini, pojedine riječi konkretnih značenja iz svagdašnjeg razgovornog jezika te pojedine osjećajno obojene riječi."

${ }^{121}$ Hudeček, Mihaljević (1997: 51) ističu da se „odnos između oznake (izraza, riječi, naziva, simbola, formule) i pojma u kojem jedan pojam ima samo jednu oznaku, a jedna oznaka pridružena je samo jednom pojmu, naziva mononimija ili jednoimenost. Kada se odnos jednoimenosti prekrši, dolazi do višeznačnoga povezivanja pojma i oznake (polisemije, homonimije i sinonimije)."

${ }^{122}$ U skupinu istraživača možemo svrstati: Dešić (1982); Dragičević (2007); Gortan-Premk (1997); Hudeček, Mihaljević, M. (1997, 2009); Krongauz (2001): Musulin (2011); Raffaelli (2009, 2015); Tafra (1986, 2003, 2016); Tafra i Košutar (2009); Samardžija (1989); Šipka (1990) i dr.

${ }^{123} \mathrm{O}$ tom problemu više je bilo riječi u napisanome poglavlju o homonimima.

${ }^{124}$ Tamaro (2008: 235) navodi kako je pravilo u leksikografiji da „svaki homonim ima svoju posebnu rječničku natuknicu, a polisemična riječ unutar jedne natuknice ima jedan formativ s više sema (značenja), poredanih brojčano od denotativnoga, primarnog značenja prema ostalim, sekundarnim, metaforičkim značenjima, i smatra se jednom jedinicom rječnika. Tri su kriterija koja leksikografi moraju uzeti u obzir kada odlučuju o tome hoće li uvrstiti jedan rječnički članak ili više njih, a to su: etimologija (ako dva leksema potječu od različitih riječi, radi se o homonimima, a ako im je podrijetlo zajedničko, to je jedna riječ s više značenja), povezanost značenja i gramatička kategorija leksema (pripadanje različitim vrstama riječi razlog je za posebnu natuknicu).“
} 
slučajnošću ${ }^{125}$ ili raspadom polisemije. No, ovaj prvi način, po njoj, nije leksikografski problem. Kako Tafra (nav. dj.: 389) kaže „Teškoće se javljaju onda kada homonimi nastaju raspadom polisemije jer je u dijakronijskom presjeku teško odrediti točnu granicu kada se polisemija raspala i kada je završen proces homonimizacije, a postoji i svijest o istom etimonu ${ }^{126}$ kao kočnica." Razlozi za depolisemizaciju, odnosno homonimizaciju mogu biti višestruki, a ona nastaje zbog divergentnoga semantičkog razvoja leksema tijekom njegove uporabe. S vremenom se asocijativne veze između semema tog leksema kidaju i svi semovi postaju distinktivni.

Stoga je nužno odrediti kriterije po kojima se na sinkronijskome planu mogu razgraničiti te dvije jezične pojave. Tafra (nav. dj.: 389-392) predlaže sematičke kriterije jer su posrijedi semantičke pojave navodeći kako polisemni leksemi imaju najmanje jedan integralni sem dok u homonimima svi semovi nemaju ni jednu zajedničku značenjsku poveznicu. Kao problem ovog kriterija navodi subjektivnost istraživača u tumačenju leksema i njihovih semema pa autorica predlaže zamjenu ${ }^{127}$ potencijalnih homonima njihovim sinonimima. Ona smatra da je riječ o homonimima ako se pokaže da zamjene nisu sinonimne i da se ne mogu supstituirati u istu rečenicu a da njezin smisao ostane isti ili je pak riječ o polisemiji ako je smisao ostao isti ${ }^{128}$.

Hudeček, Mihaljević (2009: 173-180) navode da pri razgraničavanju polisemije i homonimije treba uključiti tri kriterija: etimološki, semantički i tvorbeni kriterij iako Tafra i Samardžija etimološki kriterij isključuju smatrajući homonimiju sinkronijskim fenomenom. Mišljenja su da je taj kriterij metodološki neispravan iako kažu da može pomoći u razgraničavanju ${ }^{129}$. Kod etimološkoga kriterija nailazi se na nekoliko problema kako navode (nav. dj.: 173) i to što: ,nije uvijek poznata etimologija svake riječi, nejasno je koliko se duboko treba ići u prošlost, a govornici često ne poznaju etimologiju riječi. Naime, etimološki kriterij ne opisuje sinkronijsko (sadašnje) stanje jezika već uvodi dijakronijske (povijesne) kriterije.e

\footnotetext{
${ }^{125}$ Hudeček, Mihaljević (2009: 165) osporavaju taj način jer je tu riječ o različitim sustavima, a u drugom slučaju nije riječ o homonimima nego samo o homoformama u kanonskome obliku.

${ }^{126}$ Lingvistički iskonski oblik, osnovna riječ, etimološko ishodište, korijen iz kojeg se izvode druge riječi.

Ako se značenja mogu povezati istim etimonom, tada je riječ o polisemnom leksemu, a ako se povezuju s dvama etimonima, riječ je o homonimnim leksemima. Kriterij povezanosti i nepovezanosti značenja podrazumijeva da je, ako se radi o polisemnome leksemu, motivacijska sveza među značenjima transparentna (usp. Raffaelli 2009: 131-132).

127 Više o tom kriteriju, kao i sintagmatskoj spojivosti (treba biti različita), derivacijskoj metodi kojom se identificiraju homonimi (homonimi pripadaju različitim tvorbenim porodicama) te prijevodu na druge jezike kojim se provjerava radi li se o homonimiji ili polisemiji (homonimi će imati različite istovrijednice) u Tafra (1986).

${ }^{128}$ Za navedeni kriterij kao i za ostale zabilježene pod prethodnom natuknicom Hudeček, Mihaljević imaju svoje afirmacijsko i negacijsko mišljenje. Više u Hudeček, Mihaljević (2009: 169-172).

${ }^{129}$ Tafra (2016: 151) ističe: „Kad je riječ o izrazu, treba imati na umu da je leksem riječ u ukupnosti svojih oblika i značenja, a kad je riječ o sadržaju, da je semantička struktura slična tvorbenoj - uvijek postoji motivacija za novo značenje kao i u nastanku tvorenice."e
} 
Semantički je kriterij nepouzdan i karakterizira ga kao i kod Tafre subjektivnost interpretacije govornika jer do depolisemizacije dolazi „kada se više ne vide veze među različitim označenicima jednog označioca, tj. kad se dva značenja iste riječi toliko udalje da među njima više ne postoji nikakva veza (nav.dj.: 173). Presudnim kriterijem za utvrđivanjem homonimije stoga smatraju tvorbeni kriterij i daju mu prednost pred načelom povezanosti značenja jer: „Od dviju različitih riječi dvama neovisnim tvorbenim postupcima ne možemo dobiti jednu riječ bez obzira na to koliko su značenjski bliske riječi od kojih se tvorbenim postupkom izvode nove riječi i bez obzira na to što i te izvedenice riječi u pravilu i po logici imaju također zajednički sem i s riječima od kojih su izvedene međusobno (Hudeček i Mihaljević 2009: 175). “e Istoizrazne tvorenice ${ }^{130}$ nastale od različitih riječi smatraju homonimima, a ne polisemnim riječima, bez obzira na to što riječi od kojih su tvorene mogu imati zajednički sem ${ }^{131}$. Tafra (2016) se slaže s konstatacijom autorica da homonimi u hrvatskom jeziku mogu nastati u tvorbi kad dvije motivirajuće riječi dadu dvije tvorenice jednaka izraza (jarak > jarčić ${ }^{1}$, jarac > jarči $c^{2}$ ), ali je sporan onaj dio kad tvrde da je svaki primjer takvih tvorenica homonim ${ }^{132}$ jer su različite tvorbene osnove makar među njima postojala semantička kohezija. „Dopuštanjem da se homonimi mogu djelomice značenjski podudarati, odnosno da mogu imati koji zajednički sem poništavaju najvažniju granicu između homonimije i polisemije, ali i višestruku motivaciju

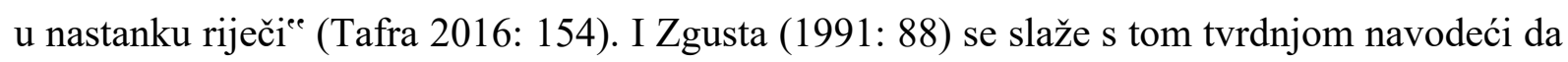
se treba: „prihvatiti kao homonimne samo parove $\mathrm{s}$ izrazito različitim nepovezanim značenjima."e

„Lyons i Ducháček klasificirali su polisemne lekseme tako što su ih razdvajali od homonima. Tako Lyons tvrdi da su prema kriteriju povezanosti značenja leksemi polisemne strukture jer je sveza među značenjima prepoznatljiva, dok su prema kriteriju nepovezanosti značenja leksemi homonimi (što znači da se značenja u polisemnoj strukturi počinju sve više

\footnotetext{
${ }^{130}$ Kao primjer Hudeček, Mihaljević (2009: 175) navode glagole oteći i oteći koje smatraju homonimima. Pri tome primjeru ne pitaju se je li posrijedi značenjski ili etimološki kriterij, dovoljan im je razlog da ti leksemi imaju različite vidske parnjake jer kako tumače (nav.dj.: 175) ,dva izrazno različita nesvršena glagola (otjecati i oticati) bit će dovoljan razlog da ne razmišljamo o tome je li oteći jedan glagol ili je riječ o dvama glagolima.

${ }^{131}$ Više u Hudeček, Mihaljević (2009: 176-184).

${ }^{132}$ Primjeri poput crveniti > crvenjenje i crvenjeti > crvenjenje; blijéštati > bljësnuti i bljëskati > bljësnuti; zvono $>$ zvonar, zvoniti > zvonar; brod > brodar, brodariti > brodar Tafra ne smatra homonimima već višeznačnicama koje su nastale višestrukom motivacijom. O simetričnome odnosu derivata i leksema, kad od jedne osnovne riječi nastane jedna tvorenica, jedan leksem ili o asimetričnome odnosu kad jednom leksemu odgovara više tvorenica, $\mathrm{i}$ obratno više u Tafra (2014). Primjerom višeznačnice zvono > zvonar, zvoniti > zvonar pozabavila se i GortanPremk (2002).
} 
odvajati). Slično njemu Ducháček razlikuje polisemne lekseme ${ }^{133}$ od homonima po tome što je značenjska veza jednih uočljivija od one u drugih (usp. Raffaelli 2009: 85).“

Asimetričnost ${ }^{134}$ kao pojava u jeziku nije neuobičajena, a pojavljuje se kao posljedica složenih odnosa gramatike i semantike i njihove međusobne isprepletenosti ${ }^{135}$. Stoga, i Tafra (2017) ukazuje na potrebu proučavanja ne samo leksičke višeznačnosti nego i gramatičke ${ }^{136} u$ koju je uključena i tvorbena jer se polisemija osim na leksičkoj javlja i na svim drugim jezičnim razinama.

Dakle, zaključno se može utvrditi kako zapravo nema jedinstvenoga stajališta niti pravila po kojem će se moći jasno razlučiti je li riječ o jednoj jezičnoj jedinici s više značenja ili su posrijedi dvije jezične jedinice jednaka izraza unutar kojih među sememima ne postoji semantička kohezija niti integralni sem.

\subsubsection{Polisemija u granicama rada}

Polisemija ili višeznačnost $u$ deseteračkim dvostisima promatra se kao pojava $u$ jezičnome sustavu. Polisemni leksem definira se jedinicom kojoj je pridružen jedan izraz i dva ili više različita sadržaja. Značenja su tih polisemnih leksema više ili manje srodna, povezana, motivirana, izvedena te među sememima mora postojati semantička kohezija jer se u protivnome može govoriti o homonimiji. Isto tako potrebno je naglasiti kako sva ta značenja

\footnotetext{
${ }^{133}$ Raffaelli razlikuje tri vrste polisemnih leksema: stabilne (imaju kognitivno istaknutu shemu i tipično značenje koje je ishodišno značenje ostalih značenjskih nijansi), stabilno-dinamičke (tipično se značenje može tumačiti prema kriteriju ishodišta značenja koje je semantičko ishodište ostalih značenjskih nijansi i značenja polisemne strukture) i dinamičke (tipično značenje nije ujedno ishodište ostalih značenja semantičke strukture). Više o vrstama polisemnih leksema i primjerima u Raffaelli (2009: 110-138).

134 „U proučavanju leksika odavno je uočeno da u leksičkom sustavu kao jednom od jezičnih podsustava postoje brojna odstupanja od idealnog odnosa dviju glavnih sastavnica što po jednoj od brojnih definicija čine riječ (leksem), tj. RIJEČ $=($ JEDAN) FORMATIV + (JEDNO) ZNAČENJE. Ta su odstupanja od ove 1:1 simetrije dapače toliko brojna da se slobodno može ustvrditi kako u leksičkom sustavu zapravo osjetno prevladavaju asimetrični odnosi jer je čas jednom formativu pridruženo više značenja, čas se isto značenje pridružuje različitim formativima ili pak dva, a rjeđe i više jednakih formativa imaju različita značenja (Samardžija 1989).“

${ }^{135}$ Zgusta (1991: 74) ističe „kako je polisemija uvijek tvrd orah za leksikografa jer ju on mora izučavati iz perspektive 'čiste' semantike, analiziranjem značenja izoliranih riječi, ali i iz perspektive gramatičkih i semantičkih kombinacija riječi.e

136 Tafra (2017: 563-575) čvrsto vjeruje i dokazuje kako se gramatika ne može valjano opisati bez utjecaja semantike te da polisemija zahvaća i gramatiku, tj. ,,između semantike i gramatike postoji neraskidiva sprega. Dok su polisemni leksemi sinkronijski odraz dijakronijskih promjena (Raffaelli 2009), gramatička značenja nisu toliko dijakronijski uvjetovana i jednostavnije ih je identificirati nego višeznačnost leksema koja je uvelike ovisna o kontekstu." Da bi lakše pojasnila navedeno Tafra (2017) opisuje slovopisnu višeznačnost, oblikotvornu višeznačnost jer polisemije u morfologiji ima mnogo i na razini oblikâ i na razini gramatičkih kategorija (navodi primjere polisemičnosti kategorije vida i broja), rječotvornu višeznačnost unutar koje bilježi dva tipa višeznačnosti; jedna zahvaća tvorenice koje su višeznačne jer su im afiksi višeznačni, a druga je "čista" rječotvorna višeznačnost nastala u slučajevima višestruke motivacije.
} 
unutar polisema nisu jednako bliska središnjemu značenju, tj. neka su bliskija, a neka su udaljenija, no među njima mora postojati semantička povezanost.

Polisemni leksem je u radu, drugim riječima, definiran kao jedna rječnička jedinica, tj. jedan formativ kojem je pridruženo više značenja (sema). Polisemija se promatra unutar jedne kategorije, jedne vrste riječi, jedne jezične jedinice, dakle unutar istoga. Iz toga slijedi kako dvije različite morfološke kategorije ne mogu biti unutar jednoga jedinoga rječničkoga članka kao što se zna u rječnicima navoditi (mlada prid. 'mlada djevojka' - mlada im. 'mladenka', stara prid. 'stara žena' - stara im. žarg. 'majka') ${ }^{137}$.

Polazeći od činjenice koju ističe Raffaelli (2007: 137) da je „polisemni leksem pod utjecajem konteksta u kojem se upotrebljava, a koji utječe na variranje postojećih značenja omogućujući stvaranje novih značenjskih nijansi ${ }^{138 e e}$ opisat će se polisemna struktura uočenih leksema. „Struktura je polisemnoga leksema stabilna, ali i istodobno podložna promjenama koje se događaju u govoru, tj. uporabom leksema i to naročito u novome kontekstualnom okruženju koje može dovesti i dovodi do nijansiranja postojećih značenja leksema (nav.dj.: $138)^{\prime \prime}$.

Stoga, cilj je ovoga rada ispitati pojedine ${ }^{139}$ polisemne lekseme i načine njihova nastanka, odnosno ispitati primat najdominantnijega načina postanka polisemije, odnos osnovnoga značenja kao strukturalno stabilnoga dijela polisema i značenjskih nijansi koji će tvoriti semantičku strukturu, tj. oblikovati izvedena značenja polisema te zabilježiti nove nijanse postojećih značenja uvjetovane danim deseteračkim dvostisima kojima bi se mogla upotpuniti leksikografska građa.

\subsubsection{Analiza polisemnih leksema deseteračkih dvostiha}

Izdvojeni polisemni leksemi uvjetovani danim deseteračkim dvostisima Jankovićeva i Lukićeva zapisa prikazat će se tablično radi preglednosti i lakše snalažljivosti. Kako se pristup

\footnotetext{
${ }^{137}$ Bilo koji primjer konverzije ne može biti polisemija jer su tu u pitanju dvije riječi, odnosno dvije jezične jedinice bez obzira što među njima postoji semantička kohezija.

${ }_{138}$ Raffaelli (2007: 139) navodi kako se taj pojam, u okviru kognitivne lingvistike, naziva i konceptualnom inovacijom jer „svaki govornik ima sposobnost uočavanja sličnosti i bliskosti novih pojavnosti s postojećim konceptima, priključiti ih odgovarajućoj konceptualnoj kategoriji i istovremeno je jezično oblikovati. Konceptualne inovacije šire i mijenjaju postojeću strukturu koncepta, odnosno uvjetuju stvaranje konceptualne kategorije te su rezultatom čovjekove kognitivne kreativnosti, sposobnosti novom, drukčijem i različitom poimanju stvarnoga svijeta. Konceptualne se inovacije odražavaju u jeziku kao nova i različita kontekstualna, tj. uporabna ostvarenja ili značenjske nijanse neke leksičke kategorije."

${ }^{139}$ Provedena analiza ne predstavlja iscrpnu korpusnu analizu odabrane leksičke građe.
} 
i određivanje pojma navedene građe razlikuje od autora do autora rječnika ${ }^{140}$, svako će se odstupanje, odnosno razlikovanje zabilježiti i dodatno pojasniti. Za potrebe opisivanja polisemnih leksema te uspoređivanja njihova osnovna značenja i značenjskih nijansi koje će oblikovati izvedena značenja polisema, a time i zabilježiti nove nijanse postojećih značenja potrebno je navoditi cjelokupni deseterački dvostih jer je za pretpostaviti kako će upravo kontekst utjecati na uočene nove nijanse postojećih leksema.

Tablica 7. Popis polisemnih leksema u deseteračkim dvostisima

\begin{tabular}{|c|c|c|}
\hline \multirow[t]{2}{*}{ Deseterački dvostih } & Etimologija & \multirow{2}{*}{$\begin{array}{c}\text { Značenje leksema u } \\
\text { stihu }\end{array}$} \\
\hline & $\begin{array}{c}\text { Rječnička jedinica i njezina } \\
\text { značenja }^{141}\end{array}$ & \\
\hline \multirow{2}{*}{$\begin{array}{l}\text { Ajde, diko, ajde lane moje } \\
\text { da pravimo nove ugovore. }\end{array}$} & u- + prasl. govorъ (tvorenica) & \multirow{2}{*}{$\begin{array}{l}\text { - dogovaranje } \\
\text { novoga odnosa } \\
\text { preneseno novo } \\
\text { značenje }\end{array}$} \\
\hline & $\begin{array}{l}\text { 1. pravn. suglasnost ili više osoba } \\
\text { ili strana o uspostavljanju } \\
\text { međusobnih odnosa i uređivanju } \\
\text { postanka, prestanka i promjena tih } \\
\text { odnosa; 2. sastanak radi ugovora }\end{array}$ & \\
\hline \multirow{2}{*}{$\begin{array}{l}\text { Alaj mojoj diki tilo vene, } \\
\text { što on nema kredita kod mene. }\end{array}$} & njem. Kredit & \multirow{2}{*}{$\begin{array}{l}\text { - uživati čije } \\
\text { povjerenje } \\
\text { preneseno novo } \\
\text { značenje }\end{array}$} \\
\hline & $\begin{array}{l}\text { 1. novac koji se nekome } \\
\text { pozajmljuje pod ugovornim } \\
\text { uvjetima; 2. davanje robe ili novca } \\
\text { na dug pod određenim uvjetima i uz } \\
\text { garanciju; 3. ekon. u dvostrukom } \\
\text { knjigovodstvu desna strana računa } \\
\text { koja se otvara nekoj ustanovi ili } \\
\text { osobi }\end{array}$ & \\
\hline \multirow{2}{*}{$\begin{array}{l}\text { Ajde, diko, da se pomirimo, } \\
\text { nitko ne zna, da ne govorimo. }\end{array}$} & prasl. govorb & \multirow[t]{2}{*}{ - (4.) razgovarati } \\
\hline & $\begin{array}{l}\text { 1. imati sposobnost prenošenja } \\
\text { poruke riječima; 2. riječima iznositi } \\
\text { neki smisao; 3. najavljivati }\end{array}$ & \\
\hline
\end{tabular}

${ }^{140}$ U svrhu analize poslužili su rječnici Anića (2003), Klaića (2002), Skoka (1971, 1972, 1973) te Jankovićeve napomene u Zbirkama pjesama S. Jankovića (1967, 1970, 1974).

${ }^{141}$ Rječnička jedinica i njezina značenja bilježeni su po Anićevu Rječniku, trenutno najvećem suvremenom rječniku hrvatskoga jezika, a ako je to značenje ili rječnička jedinica izostala, navedeno značenje navodi se po Klaiću (2002). 


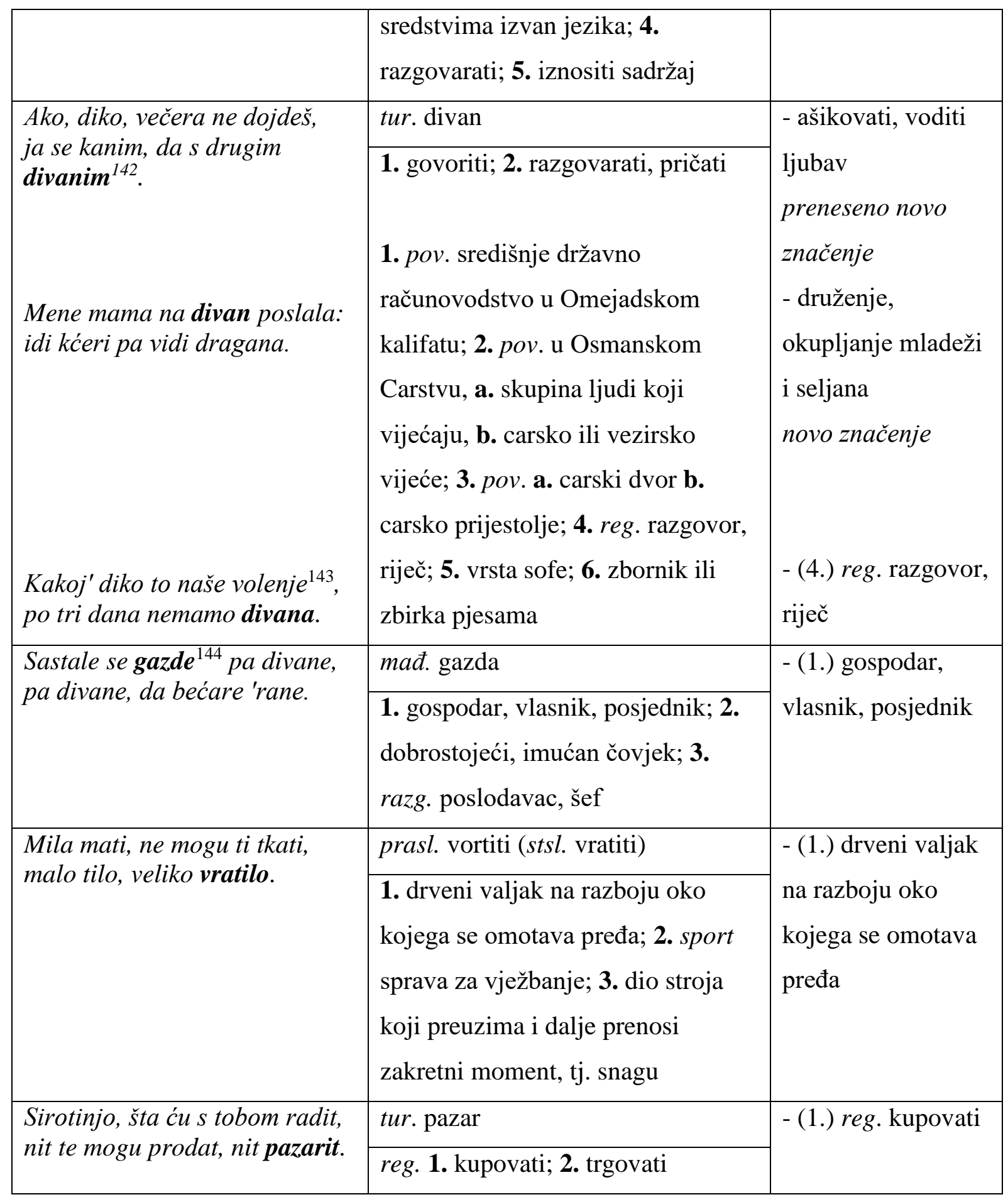

\footnotetext{
${ }^{142}$ Klaić (2002: 312) bilježi i značenje 'ašikovati, voditi ljubav' specificirajući ga za slavonski dijalekt što bi, s obzirom na navedeni kontekst, najbolje odgovaralo navedenome leksemu u danome dvostihu.

${ }^{143}$ Razliku između glagola voljeti i ljubiti detaljno je pojasnio Janković (1967:73) navodeći: „Uz pojam ljubav Šokci imaju i pojam volba (voljba, voljenje). Ljubav i volba nije isto. I u književnome jeziku postoje te dvije riječi no s drukčijim značenjem nego u Šokadiji. U književnom jeziku voljeti (voljenje) označuje osjećaj prema roditeljima ili drugim osobama, najmanje prema ljubavnom partneru. Naprotiv ljubiti (ljubav) označuje i osjećaj prema osobi protivnog spola. Dakle seksus u užem i širem smislu. U Šokadiji volba znači samo osjećaj pa i onaj među (književni rečeno) zaljubljenicima, narod bi rekao voliteljima. Ljubav počinje tjelesnim odnosom između muškarca i ženske, bez obzira da li se vole. Moglo bi se reći da je volba duhovni (psihički) odnos između dvije osobe, a ljubav tjelesni (fizički).“

${ }^{144}$ Klaić (2002: 472) nadopunjuje postojeća značenja i ovim 'domaćin, glava obitelji'.
} 


\begin{tabular}{|c|c|c|}
\hline $\begin{array}{l}\text { Jel' u koga srceko u meni, } \\
\text { da mi tilo zbog dike uveni. }\end{array}$ & $u-+$ prasl. vędnǫti (tvorenica) & \multirow[b]{2}{*}{$\begin{array}{l}\text { - (2.) pren. a. } \\
\text { izgubiti snagu i } \\
\text { svježinu (o osobi) } \\
\text { - (2.) b. pren. } \\
\text { propasti, prestati s } \\
\text { čim }\end{array}$} \\
\hline $\begin{array}{l}\text { Daleko si, lolo, med gorama } \\
\text { uvenit će ljubav među nama. }\end{array}$ & $\begin{array}{l}\text { 1. izgubiti svježinu, boju (o } \\
\text { cvijeću); 2. pren. a. izgubiti snagu i } \\
\text { svježinu (o osobi), b. pren. propasti } \\
\text { (za ono što je cvalo) }\end{array}$ & \\
\hline \multirow{2}{*}{$\begin{array}{l}\text { Veni, lolo, venit ćeš i bolje, } \\
\text { što ne grliš bilo lice moje. }\end{array}$} & prasl. vędnǫti & \multirow{2}{*}{$\begin{array}{l}\text { - patiti za kim } \\
\text { preneseno novo } \\
\text { značenje }\end{array}$} \\
\hline & $\begin{array}{l}\text { 1. gubiti snagu; sahnti (o biljkama); } \\
\text { 2. pren. gubiti snagu, zdravlje, } \\
\text { fizički slabiti }\end{array}$ & \\
\hline \multirow{2}{*}{$\begin{array}{l}\text { Ljubičica cvate sitnim plavim, } \\
\text { moje srce gine za garavim. }\end{array}$} & prasl. gybnǫti & \multirow{2}{*}{$\begin{array}{l}\text { - (2.) venuti, } \\
\text { čeznuti, žudjeti (za } \\
\text { kim, za čim) }\end{array}$} \\
\hline & $\begin{array}{l}\text { 1. gubiti život, pogibati (u ratu i } \\
\text { sl.); 2. venuti, čeznuti, žudjeti (za } \\
\text { kim, za čim) }\end{array}$ & \\
\hline \multirow[t]{2}{*}{$\begin{array}{l}\text { Srce moje svašta pregorelo } \\
\text { I onog će, koga je voljelo. }\end{array}$} & $\begin{array}{l}\text { pre- + prasl. i stsl. gorĕti } \\
\text { (tvorenica) }\end{array}$ & \multirow{2}{*}{$\begin{array}{l}\text { - (2.) prestati žaliti } \\
\text { za čim ili zbog } \\
\text { čega; preboljeti }\end{array}$} \\
\hline & $\begin{array}{l}\text { 1.a. prelomiti se izgorjevši na } \\
\text { jednom mjestu, raspasti se na } \\
\text { dijelove (od vatre), b. suviše se } \\
\text { prepeći; zagorjeti, c. prestati gorjeti } \\
\text { (o žarulji); 2. prestati žaliti za čim } \\
\text { ili zbog čega; preboljeti }\end{array}$ & \\
\hline $\begin{array}{l}\text { Dika stara priko kola šara, } \\
\text { krivo joj je, što me ne miluje. }\end{array}$ & prasl. i stsl. šarъ: boja & $\begin{array}{l}\text { - (3.) pren. razg. } \\
\text { lutati (pogledom) }\end{array}$ \\
\hline $\begin{array}{l}\text { Ja i dika šaramo svakako, } \\
\text { al' u srcu volimo se jako. }\end{array}$ & $\begin{array}{l}\text { 1.a. povlačiti crte po nečemu b. } \\
\text { pisati bez smisla; } 2 \text {. uljepšavati } \\
\text { šarama; 3. pren. razg. a. lutati, } \\
\text { vrzmati se, b. juriti u raznim } \\
\text { smjerovima, c. lagati, izvlačiti se, } \\
\text { varati, d. biti nevjeran u ljubavi }\end{array}$ & $\begin{array}{l}\text { - (3.) pren. razg. d. } \\
\text { biti nevjeran u } \\
\text { ljubavi }\end{array}$ \\
\hline \multirow{2}{*}{$\begin{array}{l}\text { Golub leti preko bilog svita, } \\
\text { nosi meni od dragoga cvita. }\end{array}$} & prasl. světъ: svjetlost, svet & \multirow{2}{*}{$\begin{array}{l}\text { - (1.) a. Zemlja sa } \\
\text { svim svojim } \\
\text { životom }\end{array}$} \\
\hline & $\begin{array}{l}\text { 1.a. Zemlja sa svim svojim životom } \\
\text { b. ljudski rod; 2. svemir: 3. ljudi, }\end{array}$ & \\
\hline
\end{tabular}




\begin{tabular}{|c|c|c|}
\hline $\begin{array}{l}\text { Svit kaže, da dukata nemam } \\
\text { Za bogata ja se i ne spremam. }\end{array}$ & $\begin{array}{l}\text { javno mišljenje; } 4 \text {. inozemstvo; } 5 \text {. } \\
\text { posebna skupina bića u prirodi; } \mathbf{6 . a .} \\
\text { ukupnost raznih fizičkih ili } \\
\text { psihičkih pojava, b. zatvoreni } \\
\text { životni prostor ili sustav, c. psih. } \\
\text { osobno iskustvo, svjetonazor }\end{array}$ & \multirow{3}{*}{$\begin{array}{l}\text { - (3.) ljudi, javno } \\
\text { mišljenje } \\
\text { - (4.) pripremati } \\
\text { (koga za što) }\end{array}$} \\
\hline \multirow[b]{2}{*}{$\begin{array}{l}\text { Svit kaže, da dukata nemam } \\
\text { Za bogata ja se i ne spremam. }\end{array}$} & $\begin{array}{l}\text { s(a)- + prasl. i stsl. prĕmiti } \\
\text { (tvorenica) }\end{array}$ & \\
\hline & $\begin{array}{l}\text { 1. v. spremiti; } 2 \text {. uređivati, stavljati } \\
\text { stvari na svoje mjesto; } 3 \text {. } \\
\text { pripravljati; gotoviti; } 4 \text {. pripremati } \\
\text { (koga za što) }\end{array}$ & \\
\hline \multirow[t]{2}{*}{$\begin{array}{l}\text { Ne bi dala obrvice tanke, } \\
\text { lane moje, ni za kake banke. }\end{array}$} & $\begin{array}{l}\text { tal. banca: stol, tezga, stol mjenjača } \\
\text { novca }\end{array}$ & \multirow{2}{*}{$\begin{array}{l}\text { - novac općenito } \\
\text { metonimija novo } \\
\text { značenje }\end{array}$} \\
\hline & $\begin{array}{l}\text { 1. ekon. ustanova koja posreduje u } \\
\text { novčanom prometu; 2. mjesto gdje } \\
\text { je nešto pohranjeno; 3. tehn. bilo } \\
\text { koja skupina sličnih električnih } \\
\text { uređaja povezanih u jedan sklop; } 4 \text {. } \\
\text { inform. dio računalne memorije; } 5 \text {. } \\
\text { pov. žarg. a. kovani komad novca } \\
\text { od } 10 \text { dinara KJ, b. } 10 \text { kuna kao } \\
\text { novčana jedinica NDH, c. } 10 \text { dinara } \\
\text { ili } 10 \text { para SFRJ; } 6 \text {. žarg. } 10 \text { godina } \\
\text { u brojenju ljudskih godina }\end{array}$ & \\
\hline \multirow{2}{*}{$\begin{array}{l}\text { Položit ću ispod vrata zlato, } \\
\text { pa ću moje školovati drago. }\end{array}$} & prasl. zolto & \multirow{2}{*}{$\begin{array}{l}\text { - (2.) meton. } \\
\text { ukupnost predmeta } \\
\text { od zlata (nakit, } \\
\text { zlatnici) }\end{array}$} \\
\hline & $\begin{array}{l}\text { 1. kem. element (Au); 2. meton. } \\
\text { ukupnost predmeta od zlata (nakit, } \\
\text { zlatnici); 3. pren. a. ono što mnogo } \\
\text { vrijedi, b. naziv odmila, c. sjaj zlata }\end{array}$ & \\
\hline \multirow{2}{*}{$\begin{array}{l}\text { I u mene ko u moje dike, } \\
\text { tri tkanice jednake vunice. }\end{array}$} & prasl. vblna & \multirow{2}{*}{$\begin{array}{l}\text { - (2.) meton. } \mathbf{a} . \\
\text { predivo od guste, } \\
\text { mekane i kovrčaste }\end{array}$} \\
\hline & $\begin{array}{l}\text { 1. gusta, mekana i kovrčasta dlaka } \\
\text { koja raste na koži ovce; } 2 \text {. meton. a. }\end{array}$ & \\
\hline
\end{tabular}




\begin{tabular}{|c|c|c|}
\hline & $\begin{array}{l}\text { predivo od te dlake, b. tvar slična } \\
\text { vuni koja se dobiva kemijskim } \\
\text { putem; 3. žarg. strah, trema }\end{array}$ & $\begin{array}{l}\text { dlake koja raste na } \\
\text { koži ovce }\end{array}$ \\
\hline \multirow{2}{*}{$\begin{array}{l}\text { Piši diko jedno slovo malo, } \\
\text { što je tebi na me tako žao. }\end{array}$} & prasl. i stsl. slovo: riječ & \multirow{2}{*}{$\begin{array}{l}\text { - pismo, obavijest } \\
\text { metonimija novo } \\
\text { značenje }\end{array}$} \\
\hline & $\begin{array}{l}\text { 1. pismeni znak u alfabetskom } \\
\text { pismu; 2. retor. (prigodni) govor }\end{array}$ & \\
\hline \multirow{4}{*}{$\begin{array}{l}\text { Oj, svekrvo, ti neka se jesti, } \\
\text { svejedno ću u komoru sjesti. }\end{array}$} & prasl. (j)ěsti & \multirow{2}{*}{$\begin{array}{l}\text { - (2.) ljutiti se u } \\
\text { sebi, gristi se }\end{array}$} \\
\hline & $\begin{array}{l}\text { 1. žvakati i gutati jelo, hraniti se; } 2 \text {. } \\
\text { ljutiti se u sebi, gristi se; 3. pren. } \\
\text { izjedati koga, dosađivati }\end{array}$ & \\
\hline & lat. camera: svod sobe, soba & \multirow{2}{*}{$\begin{array}{l}\text { - (1.) razg. a. soba } \\
\text { za spavanje u } \\
\text { seljačkoj kući; izba }\end{array}$} \\
\hline & $\begin{array}{l}\text { 1. razg. a. soba za spavanje u } \\
\text { seljačkoj kući; izba, b. smočnica, } \\
\text { ostava; 2. term. zatvoren prostor ili } \\
\text { unutrašnjost čega uređen za } \\
\text { određene potrebe; 3. vojn. pov. } \\
\text { formacija ili dio vojne jedinice s } \\
\text { konjima i vozilima koja prevozi } \\
\text { hranu i dr. potrepštine; 4. ekon. } \\
\text { ustanova koja zastupa interes jedne } \\
\text { grane djelatnosti; 5.a. tijelo u } \\
\text { zakonodavnoj vlasti u nekim } \\
\text { zemljama, b. državna blagajna }\end{array}$ & \\
\hline \multirow[t]{2}{*}{$\begin{array}{l}\text { Dika kaže, da će se otrovat, } \\
\text { što ja neću s njime ašikovat. }\end{array}$} & $\begin{array}{l}\text { tur. aşk < arap.; tur. âşàk: ljubiti, } \\
\text { voljeti }\end{array}$ & \multirow[t]{2}{*}{$\begin{array}{l}\text { - voditi ljubav }{ }^{145} \\
\text { novo značenje }\end{array}$} \\
\hline & $\begin{array}{l}\text { reg. ekspr. udvarati se djevojci; } \\
\text { ljubovati }\end{array}$ & \\
\hline \multirow{2}{*}{$\begin{array}{l}\text { Varaj, diko, devet divojaka, } \\
\text { devet varaj, za me ljubav } \\
\text { šparaj. }\end{array}$} & njem. sparen & \multirow{2}{*}{$\begin{array}{l}\text { - čuvati što za } \\
\text { trajno vezivanje }\end{array}$} \\
\hline & $\begin{array}{l}\text { razg. 1. (što) a. biti umjeren u } \\
\text { trošenju novca, materijala itd., b. }\end{array}$ & \\
\hline
\end{tabular}

${ }^{145}$ Janković (1967: 152) tumači da je ,,... ašikovanje ljubav, te ašikovati znači voditi ljubav. Kao i mnoge tuđice, i ova je riječ kod nas dobila posebno značenje. Znači očijukanje, sastajanje, razgovaranje i uopće ljubavni odnos.“ Klaićevo (2002: 112) određenje leksema prati Jankovićeve bilješke te on bilježi dva značenja: '1. voljeti se, milovati se; ljubavno razgovarati; 2. udvarati, voditi ljubav' dok je kod Anića navedeni leksem monoseman. 


\begin{tabular}{|c|c|c|}
\hline $\begin{array}{l}\text { Ljubit ću se, šparovat se neću, } \\
\text { znam za cilo istrunit će tilo. }\end{array}$ & $\begin{array}{l}\text { držati novac u banci; štedjeti; } 2 \text {. } \\
\text { (koga) biti obazriv, pažljiv prema } \\
\text { kome; 3. (se) ne trošiti pretjerano } \\
\text { snagu, čuvati se }\end{array}$ & $\begin{array}{l}\text { preneseno novo } \\
\text { značenje } \\
\text { - (2.) ne biti } \\
\text { obazriv, pažljiv } \\
\text { prema sebi }\end{array}$ \\
\hline \multirow{4}{*}{$\begin{array}{l}\text { Šćer, kava, to je moja 'rana, } \\
\text { za inoću }^{146} \text { dobra i tarana. }\end{array}$} & tur. kahve & \multirow{4}{*}{$\begin{array}{l}\text { - (2.) meton. } \\
\text { napitak priređen od } \\
\text { pržena ploda kave } \\
\text { - (2.) razg. } \\
\text { ljubavnica } \\
\text { oženjena čovjeka, } \\
\text { priležnica }{ }^{147}\end{array}$} \\
\hline & $\begin{array}{l}\text { 1. bot. grmolika biljka zrnata ploda; } \\
\text { 2. meton. napitak priređen od } \\
\text { pržena ploda kave }\end{array}$ & \\
\hline & prasl. i stsl. inъ: drugi, drugo & \\
\hline & $\begin{array}{l}\text { 1. pov. etnol. druga žena koja ulazi } \\
\text { u kuću pored prve, prema } \\
\text { mogućnostima koje ostavljaju } \\
\text { islamski zakoni; 2. razg. ljubavnica } \\
\text { oženjena čovjeka }\end{array}$ & \\
\hline \multirow{2}{*}{$\begin{array}{l}\text { Oči moje kao u gavrana, } \\
\text { izmamile kalfu iz dućana. }\end{array}$} & tur. kalfa & \multirow{2}{*}{$\begin{array}{l}\text { - (1.) pov. izučeni } \\
\text { obrtnčki ili } \\
\text { trgovački } \\
\text { pomoćnik }\end{array}$} \\
\hline & $\begin{array}{l}\text { 1. pov. izučeni obrtnički ili } \\
\text { trgovački pomoćnik; 2. reg. } \\
\text { pomoćnik hodže u mektebu }\end{array}$ & \\
\hline \multirow{2}{*}{$\begin{array}{l}\text { A šta će mi taj garavi momak, } \\
\text { kad on ide ženama na konak. }\end{array}$} & tur. konmak: odsjesti, biti gost & \multirow{2}{*}{$\begin{array}{l}\text { - radnje vezane uz } \\
\text { noćenje i ljubavno } \\
\text { umijeće } \\
\text { preneseno novo } \\
\text { značenje }\end{array}$} \\
\hline & $\begin{array}{l}\text { 1. noćenje; 2. reg. a. kuća, dom, b. } \\
\text { kuća kakvog uglednika; 3. reg. pov. } \\
\text { jednodnevno putovanje; 4. reg. pov. } \\
\text { zgrada valije; saraj, dvor, } \\
\text { rezidencija; 5. zgrada u Sarajevu u } \\
\text { kojoj borave visoki strani gosti; } 6 \text {. } \\
\text { mjesto u kući orijentalne gradnje } \\
\text { gdje borave ili žive samo muškarci }\end{array}$ & \\
\hline
\end{tabular}

${ }^{146}$ Janković (1974: 5) bilježi kako je „U našoj književnosti izraz dosta rijedak, a u mnogim krajevima sasvim nepoznat. Inoča je suparnica u ljubavi. Dvije djevojke ili žene koje vole istog muškarca, ili se otimaju za njega, nazivaju jedna drugu inočom. Taj izraz se pojavljuje u vrlo starim ispravama i književnim spisima. Neki misle (Lovretić) da se piše sa "ć", jer da je riječ nastala "inat" ili "inatiti se". Tobože se dvije ženske inate (svađaju) za muškarca. No nije tako! Riječ je nastala od "inoče", "inaka", tj. "druga". Zato se piše sa "č" U staroj književnosti pojavljuje se ponekad i riječ "inok", što znači suparnik u ljubavi. U Šokadiji taj izraz više ne postoji.“

${ }^{147}$ Skok (1971: 720) tumači da je inoča „1. druga žena; 2. priležnica (Slavonija)“. 


\begin{tabular}{|c|c|c|}
\hline \multirow{2}{*}{$\begin{array}{l}\text { Čuješ, seko, nješta bi ti reko: } \\
\text { Bježi, seko, od mene daleko. }\end{array}$} & prasl. i stsl. sestra (umanjenica) & \multirow{2}{*}{$\begin{array}{l}\text { - (ne)udana ženska } \\
\text { osoba općenito } \\
\text { metonimija novo } \\
\text { značenje }\end{array}$} \\
\hline & $\begin{array}{l}\text { 1. kći istih roditelja prema drugoj } \\
\text { djeci tih roditelja; 2. ženska osoba } \\
\text { sa SSS u zdravstvenim ustanovama; } \\
\text { 3.a. } \text { crkv. ženski dio crkvene } \\
\text { pastve, b. pol. zast. ženski dio } \\
\text { građanstva }\end{array}$ & \\
\hline \multirow{2}{*}{$\begin{array}{l}\text { Dojdi, diko, nije ti daleko, } \\
\text { šest numera do mog kiljera. }\end{array}$} & lat. numerus: označavati brojkom & \multirow{2}{*}{$\begin{array}{l}\text { - potkućnica }{ }^{148}, \mathrm{tj} . \\
\text { područje za obradu } \\
\text { zemlje iza kuće } \\
\text { novo značenje }\end{array}$} \\
\hline & $\begin{array}{l}\text { 1. reg. broj, brojka; 2. reg. kuća i } \\
\text { okućnica, gradilište; 3. meton. } \\
\text { popularna pjesma; glazbeni broj }\end{array}$ & \\
\hline \multirow{2}{*}{$\begin{array}{l}\text { Mjesečina, mjesec u oblaku, } \\
\text { čekaj mene curo na sokaku }{ }^{149} \text {. }\end{array}$} & tur. sokak & \multirow{2}{*}{$\begin{array}{l}\text { - (2.) reg. ulica u } \\
\text { ravničarskim } \\
\text { naseljima, npr. u } \\
\text { Slavoniji }\end{array}$} \\
\hline & $\begin{array}{l}\text { reg. 1. manja, uža ulica ili prolaz; } \\
\text { 2. reg. ulica u ravničarskim } \\
\text { naseljima, npr. u Slavoniji; 3. pejor. } \\
\text { neugledna, uska ulica }\end{array}$ & \\
\hline \multirow{2}{*}{$\begin{array}{l}\text { Priko puta jedna cura ljuta, } \\
\text { pa od zala u šamac upala. }\end{array}$} & njem. Schanze & \multirow{2}{*}{$\begin{array}{l}\text { - (veliki) kanal }{ }^{150} \\
\text { novo značenje }\end{array}$} \\
\hline & $\begin{array}{l}\text { 1. reg. opkop, reduta; 2. vojn. } \\
\text { poljsko utvrđenje koje ima visok } \\
\text { profil }\end{array}$ & \\
\hline \multirow{2}{*}{$\begin{array}{l}\text { Diko slatka, idi iz pojatka, } \\
\text { dojt' će mama, a ja nisam } \\
\text { sama. }\end{array}$} & bug. pojata: košara & \multirow{2}{*}{$\begin{array}{l}\text { - spavaonica u } \\
\text { zadružnim kućama } \\
\text { (Srijem) })^{151} \\
\text { novo značenje }\end{array}$} \\
\hline & 1. štagalj; 2. staja & \\
\hline \multirow{2}{*}{$\begin{array}{l}\text { U sobici krevet do tavana }{ }^{152}, \\
\text { dojdi, diko, da ne spavam } \\
\text { sama. }\end{array}$} & tur. tavan & \multirow[t]{2}{*}{ - (2.) reg. a. strop } \\
\hline & $\begin{array}{l}\text { 1. potkrovlje; 2. reg. a. strop, b. } \\
\text { kat, c. pod, daske na podu; 3. pren. } \\
\text { razg. gornja granica čega }\end{array}$ & \\
\hline
\end{tabular}

\footnotetext{
148 Janković (1967: 137) tumači da je „Numera potkućnica. To znači da stanuju na istoj strani ulice. Dalje znači: neka dođe odotraga (a ne ulicom) i da mora preskočiti šest plotova.“

${ }^{149}$ Klaić (2002: 1247) leksem ne vidi kao polisemični već ga bilježi jednom natuknicom kao 'ulica, cesta, put'.

${ }^{150}$ Skok (1973: 380) definira leksem kao 'opkop, obrov, reduta, kod nas veliki kanal'.

${ }^{151}$ Skok (1972: 695) navodi dva značenja: '1. staja, hlijev, tor, pljevara, vajat, koliba, sjenik, košara, kuća za slamu, sijeno i spavanje ljudi; 2 . u zadružnim kućama spavaonica'.

${ }^{152}$ Janković (1967: 141) tumači da su ,u sobici, tj. u kućaru, a obično i u drugim sobama, na krevetima po tri reda jastuka (vanjkuša), po tri velika, srednja i mala. Sobica je niska, pa to zaista naraste do tavana, tj. do stropa.“
} 


\begin{tabular}{|c|c|c|}
\hline \multirow{2}{*}{$\begin{array}{l}\text { Meni kažu, da ja nemam dike, } \\
\text { nitko ne zna moje politike. }\end{array}$} & grč. politikos & \multirow[b]{2}{*}{$\begin{array}{l}\text { - preneseno } \\
\text { lukavost, } \\
\text { prepredenost, } \\
\text { „računica“, } \\
\text { smišljenost, } \\
\text { proračunatost }\end{array}$} \\
\hline & $\begin{array}{l}\text { 1. djelatnost koja teži uređenju } \\
\text { društva; 2. umijeće i način vladanja } \\
\text { državom; 3. opće usmjerenje i } \\
\text { način upravljanja djelatnošću nekog } \\
\text { posebnog područja; 4. ponašanje, } \\
\text { odnosi i način odnošenja države u } \\
\text { široj zajednici; 5. zastupanje } \\
\text { interesa neke države; } 6 \text {. djelatnost } \\
\text { koja teži pridobivanju javnosti za } \\
\text { neki program }\end{array}$ & \\
\hline \multirow[t]{2}{*}{$\begin{array}{l}\text { Diko lane, visoki jablane, } \\
\text { ja ću tvoje salomiti grane. }\end{array}$} & $\begin{array}{l}\mathrm{s}(\mathrm{a})-+ \text { prasl. lomb, lomiti } \\
\text { (tvorenica) }\end{array}$ & \multirow{2}{*}{$\begin{array}{l}\text { - (3.) c. pren. biti } \\
\text { svladan, odstupiti } \\
\text { od svog uvjerenja, } \\
\text { pokoriti se }\end{array}$} \\
\hline & $\begin{array}{l}\text { 1.a. upotrebom snage krutu cjelinu } \\
\text { razbiti na dijelove, b. padom ili } \\
\text { udarom izazvati lom kosti; 2. pren. } \\
\text { oduzeti komu sposobnost otpora ili } \\
\text { nezavisnog mišljenja; 3.a. prelomiti } \\
\text { se, b. teško se ozlijediti pri padu, c. } \\
\text { pren. biti svladan, odstupiti od svog } \\
\text { uvjerenja, pokoriti se }\end{array}$ & \\
\hline \multirow{2}{*}{$\begin{array}{l}\text { Ja ovako garava pa fina, } \\
\text { pa da ljubim koječijeg sina!? }\end{array}$} & njem. fein & \multirow{2}{*}{$\begin{array}{l}\text { - (2.) pren. a. koja } \\
\text { je uglađena; } \\
\text { pristojna }\end{array}$} \\
\hline & $\begin{array}{l}\text { 1.a. koji je tanak, b. koji je malih } \\
\text { dimenzija, c. koji je precizno } \\
\text { izrađen; 2. pren. a. koji je uglađen; } \\
\text { pristojan, b. koji je istančan; } 3 \text {. } \\
\text { razg. koji je ukusan (o hrani) }\end{array}$ & \\
\hline \multirow{2}{*}{$\begin{array}{l}\text { Mene moja naredila mama: } \\
\text { „Idi kolu lutko molovana“ }\end{array}$} & prasl. lǫtъka & \multirow{2}{*}{$\begin{array}{l}\text { - (3.) a. hip. naziv } \\
\text { odmila }\end{array}$} \\
\hline & $\begin{array}{l}\text { 1.a. igračka za djecu, b. figura } \\
\text { trupa odrasle osobe; 2. pren. osoba } \\
\text { kojom drugi upravljaju; 3.a. hip. }\end{array}$ & \\
\hline
\end{tabular}

${ }^{153}$ Za razliku od Anića, Klaić (2002: 1066) navodi preneseno značenje leksema politika koje odgovara kontekstu dvostiha. 


\begin{tabular}{|c|c|c|}
\hline & $\begin{array}{l}\text { naziv odmila, b. mlađa osoba } \\
\text { slatkaste ljepote }\end{array}$ & \\
\hline \multirow{2}{*}{$\begin{array}{l}\text { Ja ne ljubim lane sa jabane, } \\
\text { već komšiju, što je na očiju. }\end{array}$} & tur. yaban & \multirow{2}{*}{$\begin{array}{l}\text { - (3.) b. strani } \\
\text { svijet, inozemstvo }\end{array}$} \\
\hline & $\begin{array}{l}\text { reg. ekspr. 1.a. pusta, neobrađena } \\
\text { zemlja, b. pren. duhovna pustinja; } \\
\text { ništavilo; 2. došljak; 3.a. tuđinac, b. } \\
\text { strani svijet, inozemstvo }\end{array}$ & \\
\hline \multirow{2}{*}{$\begin{array}{l}\text { Mene grde po selu beštije } \\
\text { radi moga poštenog komšije. }\end{array}$} & tal. bestia & \multirow{2}{*}{$\begin{array}{l}\text { - (2.) pren. pejor. } \\
\text { onaj koji ima loše } \\
\text { osobine, okrutan }\end{array}$} \\
\hline & $\begin{array}{l}\text { 1. reg. životinja; 2. pren. pejor. } \\
\text { onaj koji ima loše osobine, okrutan }\end{array}$ & \\
\hline \multirow{2}{*}{$\begin{array}{l}\text { Lipa seka, dok je apoteka, } \\
\text { sunce sini, apoteku skini. }\end{array}$} & njem. Apotheke & \multirow{2}{*}{$\begin{array}{l}\text { - šminka }{ }^{154} \\
\text { preneseno novo }^{\text {značenje }}\end{array}$} \\
\hline & $\begin{array}{l}\text { 1. mjesto gdje se stručno priređuju i } \\
\text { prodaju lijekovi; ljekarna 2. iron. } \\
\text { mjesto gdje je sve skupo }\end{array}$ & \\
\hline \multirow{2}{*}{$\begin{array}{l}\text { Moj se dika na mašini šiša, } \\
\text { a ja nosim maramu od pliša. }\end{array}$} & njem. Maschine & \multirow{2}{*}{$\begin{array}{l}\text { - mali uređaj za } \\
\text { šišanje } \\
\text { novo značenje }\end{array}$} \\
\hline & $\begin{array}{l}\text { reg. }(+ \text { srp. }) \text { 1. stroj; } 2 . \text { motorno } \\
\text { vozilo; 3. pren. a. čvrsta } \\
\text { organizacija; mašinerija, b. onaj } \\
\text { koji radi sve po naredbi, c. onaj koji } \\
\text { radi brzo i dobro }\end{array}$ & \\
\hline \multirow{2}{*}{$\begin{array}{l}\text { Alaj volim, kad tambura svira, } \\
\text { kad moj lola njome } \\
\text { komandira. }\end{array}$} & njem. kommandieren & \multirow[t]{2}{*}{ - (2.) upravljati } \\
\hline & $\begin{array}{l}\text { 1. zapovjediti/zapovijedati, } \\
\text { izdati/izdavati zapovijedi; } 2 \text {. } \\
\text { dovesti/voditi, upravljati, imati pod } \\
\text { komandom, kontrolom }\end{array}$ & \\
\hline \multirow{2}{*}{$\begin{array}{l}\text { Gori lampa, cilindera nema, } \\
\text { moja dika u tavanu večera. }\end{array}$} & njem. Zylinder & \multirow{2}{*}{$\begin{array}{l}\text { - (3) stakleni dio } \\
\text { petrolejske } \\
\text { svjetiljke }\end{array}$} \\
\hline & $\begin{array}{l}\text { 1. mat. valjak; geometrijsko tijelo; } \\
\text { 2. tehn. a. šuplje ili puno tijelo } \\
\text { valjkasta oblika, b. u parnim } \\
\text { strojevima valjkasta komora u kojoj } \\
\text { radni medij pokreće klip; 3. stakleni }\end{array}$ & \\
\hline
\end{tabular}

${ }^{154}$ Klaić (2002: 88) tumači leksem apoteka četirima značenjima od kojih 4. 'sredstva za uljepšavanje' odgovara značenju leksema u danom kontekstu dvostiha. 


\begin{tabular}{|c|c|c|}
\hline & $\begin{array}{l}\text { dio petrolejske svjetiljke; } 4 \text {. visoki } \\
\text { tvrdi šešir valjkasta oblika }\end{array}$ & \\
\hline \multirow{2}{*}{$\begin{array}{l}\text { Gledaj, diko, tu zelenu travu, } \\
\text { tako ćeš se i ti zeleniti }{ }^{155} \text { ! }\end{array}$} & prasl. i stsl. zelenъ & \multirow{2}{*}{$\begin{array}{l}\text { - ostati neženja, } \\
\text { vječno mlad } \\
\text { preneseno novo } \\
\text { značenje }\end{array}$} \\
\hline & $\begin{array}{l}\text { 1. biti zelen, isticati se zelenom } \\
\text { bojom }\end{array}$ & \\
\hline \multirow{2}{*}{$\begin{array}{l}\text { Meni kažu, da sam ja šarena, } \\
\text { što sam tako u kolu adrena. }\end{array}$} & prasl. i stsl. šarb: boja & \multirow{2}{*}{$\begin{array}{l}\text { - (2.) pren. pejor. } \\
\text { b. nepouzdana, } \\
\text { sumnjiva osoba }\end{array}$} \\
\hline & $\begin{array}{l}\text { 1. koji je od više boja; raznobojan; } \\
\text { 2. pren. pejor. a. sastavljen od } \\
\text { raznovrsnih sastojaka; raznolik, b. } \\
\text { nepouzdan, sumnjiv (o osobi) }\end{array}$ & \\
\hline \multirow{2}{*}{$\begin{array}{l}\text { Grlo moje ko u tice sojke } \\
\text { nije tako u svake đevojke. } \\
\text { Zalud cure, što pjevati znade, } \\
\text { kada lipo grlo ne imade. }\end{array}$} & prasl. gъrdlo & \multirow{2}{*}{$\begin{array}{l}\text { - glas } \\
\text { metonimija novo } \\
\text { značenje }\end{array}$} \\
\hline & $\begin{array}{l}\text { 1. anat. ždrijelna duplja s gornjim } \\
\text { dijelom grkljana i jednjakom; } 2 \text {. } \\
\text { razg. prednja strana vrata; 3. sport } \\
\text { konj; 4. suženje ili izlaz iz čega što } \\
\text { se sužava; 5. tjesnac, sutjeska }\end{array}$ & \\
\hline \multirow{2}{*}{$\begin{array}{l}\text { Kad prođem kraj dikina dvora, } \\
\text { svekrva mi zalajati mora. }\end{array}$} & za- + prasl. i stsl. lajati (tvorenica) & \multirow{2}{*}{$\begin{array}{l}\text { - psovati, ružno } \\
\text { govoriti } \\
\text { preneseno novo } \\
\text { značenje }\end{array}$} \\
\hline & $\begin{array}{l}\text { 1. početi lajati; 2. pren. pejor. } \\
\text { mnogo govori }\end{array}$ & \\
\hline \multirow{2}{*}{$\begin{array}{l}\text { Ja i lane ciganski živimo, } \\
\text { svadimo se, pa se pomirimo. }\end{array}$} & od Ciganin (mađ. czigány) & \multirow{2}{*}{$\begin{array}{l}\text { - živjeti u svađi }{ }^{156} \\
\text { preneseno novo } \\
\text { značenje }\end{array}$} \\
\hline & $\begin{array}{l}\text { 1. koji se odnosi na Cigane (Rome); } \\
\text { 2. pejor. a. koji je nestalna } \\
\text { prebivališta; skitalački, b. koji je } \\
\text { sklon sitnim prevarama }\end{array}$ & \\
\hline \multirow{2}{*}{$\begin{array}{l}\text { Ja sam mala, al sam velik } \\
\text { jarac, } \\
\text { ni oče mi ne gledaju na pravac. }\end{array}$} & prasl. jаrьсь & \multirow{2}{*}{$\begin{array}{l}\text { - vrckava, nemirna, } \\
\text { prevrtljiva, } \\
\text { tvrdoglava, } \\
\text { temperamentna } \\
\text { ličnost }\end{array}$} \\
\hline & $\begin{array}{l}\text { 1. zool. mužjak koze; 2.a. nogari za } \\
\text { piljenje drva, b. sport gimnastička } \\
\text { sprava za preskakanje; 3. zodijački } \\
\text { znak od 22. prosinca do 20. siječnja }\end{array}$ & \\
\hline
\end{tabular}

${ }^{155} \mathrm{U}$ Šokadiji, u govoru starih u grafemskom smislu nemamo razlikovanja leksema zeleniti i zelenjeti se što je u ovom dvostihu i uočljivo.

${ }^{156}$ Janković (1970: 21) tumači da se „Cigani zaista često svađaju, pa je zato i nastala uzrečica: žive ciganski.“ 


\begin{tabular}{|c|c|c|}
\hline & & $\begin{array}{l}\text { preneseno novo } \\
\text { značenje }\end{array}$ \\
\hline \multirow{3}{*}{$\begin{array}{l}\text { Mila mamo, kupi meni svilu, } \\
\text { obuci me kano bilu vilu. }\end{array}$} & prasl. sbvila & \multirow{4}{*}{$\begin{array}{l}\text { - vrsta ženske } \\
\text { suknje od } \\
\text { svile/svilena rubina } \\
\text { metonimija novo } \\
\text { značenje } \\
\text { - sin od milja, } \\
\text { majčin izraz za sina } \\
\text { preneseno novo } \\
\text { značenje }\end{array}$} \\
\hline & $\begin{array}{l}\text { 1. tanko vlakno dobiveno } \\
\text { odmatanjem čahura dudova svilca; } \\
\text { 2. meton. tkanina od takva vlakna; } \\
\text { 3. pren. ono što nježnošću i sjajem } \\
\text { podsjeća na svilu; 4. reg. biljna } \\
\text { vlakna na vrhu klipa kukuruza }\end{array}$ & \\
\hline & prasl. i stsl. golǫbь & \\
\hline $\begin{array}{l}\text { Plava svila, velika poruba, } \\
\text { neće majka da ženi goluba. }\end{array}$ & $\begin{array}{l}\text { 1. zool. ptica; 2. hrskavična morska } \\
\text { riba; 3. pren. političar umjerenih } \\
\text { pogleda, miroljubiv }\end{array}$ & \\
\hline \multirow{2}{*}{$\begin{array}{l}\text { Mjesečina, pa se gaće bile, } \\
\text { kako j' ala s mojom dikom } \\
\text { stala. }\end{array}$} & prasl. gatje & \multirow{2}{*}{$\begin{array}{l}\text { - donji dio muške } \\
\text { nošnje, tj. hlača, } \\
\text { odjevni predmet }^{157} \\
\text { novo značenje }\end{array}$} \\
\hline & $\begin{array}{l}\text { 1. donji dio muškog i ženskog } \\
\text { rublja }\end{array}$ & \\
\hline \multirow{2}{*}{$\begin{array}{l}\text { Ja ne nosim somet oko vrata, } \\
\text { već plantike, da me volju dike. }\end{array}$} & njem. Samt & \multirow[b]{2}{*}{$\begin{array}{l}\text { - plišana tanka } \\
\text { traka koja se stavlja } \\
\text { djevojci oko vrata } \\
\text { kao ukras } \\
\text { metonimija novo } \\
\text { značenje }\end{array}$} \\
\hline & $\begin{array}{l}\text { reg. vrsta mekane tkanine, baršun, } \\
\text { kadifa, pliš }\end{array}$ & \\
\hline \multirow{2}{*}{$\begin{array}{l}\text { Žito vozi moja mila dika, } \\
\text { čim me spazi sa voza silazi. }\end{array}$} & prasl. vozь & \multirow{2}{*}{$\begin{array}{l}\text { - seoska kola } \\
\text { natovarena } \\
\text { snopovima žita } \\
\text { novo značenje }\end{array}$} \\
\hline & $\begin{array}{l}\text { 1. zaprežna kola kao mjera količine } \\
\text { tereta; 2. } s r p \text {. vlak }\end{array}$ & \\
\hline \multirow{2}{*}{$\begin{array}{l}\text { Pijem pivo, jel' ti diko krivo, } \\
\text { pijem šerbe, ostavit ću tebe. }\end{array}$} & tur. şerbet & \multirow{2}{*}{$\begin{array}{l}\text { - reg. } 1 . \\
\text { istočnjačko } \\
\text { osvježavajuće piće }\end{array}$} \\
\hline & $\begin{array}{l}\text { reg. 1. istočnjačko osvježavajuće } \\
\text { piće od vode, šećera ili meda te }\end{array}$ & \\
\hline
\end{tabular}

${ }^{157}$ Skok (1971: 542) navodi dva značenja leksema gaće: '1. platneno donje odijelo; 2. sinonimu hlače, čakšire, pantaloni (Brač, Čilipi)' koja bi odgovarala značenju leksema u danom kontekstu dvostiha. 


\begin{tabular}{|c|c|c|}
\hline & $\begin{array}{l}\text { mirodija; 2. uzavrela voda u } \\
\text { šerbetluku pripremljena za kuhanje } \\
\text { kave; 3. ukuhan šećer kojim se } \\
\text { zalijevaju slatke pite }\end{array}$ & $\begin{array}{l}\text { od vode, šećera ili } \\
\text { meda te mirodija }\end{array}$ \\
\hline \multirow{2}{*}{$\begin{array}{l}\text { Cura ruva tri ormana sprema, } \\
\text { uzalud joj, kad ašika nema. }\end{array}$} & prasl. ruxo & \multirow[b]{2}{*}{$\begin{array}{l}\text { - (2.) etnol. } \\
\text { djevojačka oprema } \\
\text { koju udavača } \\
\text { odnosi u } \\
\text { mladoženjinu kuću }\end{array}$} \\
\hline & $\begin{array}{l}\text { 1. odjeća, haljine; roba; 2. etnol. } \\
\text { djevojačka oprema koju udavača } \\
\text { odnosi u mladoženjinu kuću; } 3 \text {. } \\
\text { svećenička odjeća }\end{array}$ & \\
\hline $\begin{array}{l}\text { Nisam došo u kolo igrati, } \\
\text { već sam došo cure izbirati. }\end{array}$ & prasl. jьgra & $\begin{array}{l}\text { - (6.) a. etnol. } \\
\text { plesati kolo }\end{array}$ \\
\hline $\begin{array}{l}\text { Oče moje igraje u glave, } \\
\text { koga vidu, onog i namame. }\end{array}$ & $\begin{array}{l}\text { 1. provoditi vrijeme u kakvoj igri; } \\
\text { 2. natjecati se; 3. reg. } \text { zast. svirati } \\
\text { kakav instrument; 4. titrati, } \\
\text { treperiti; 5. glumiti; 6.a. } \text { etnol. } \\
\text { plesati kolo, b. plesati; } 7 \text {. } \\
\text { prikazivati se u kinu }\end{array}$ & $\begin{array}{l}\text { - biti nemiran, } \\
\text { živahan } \\
\text { preneseno novo } \\
\text { značenje }\end{array}$ \\
\hline \multirow{2}{*}{$\begin{array}{l}\text { Kaži meni golubice biela, } \\
\text { koliko si imala švalera? }\end{array}$} & austr. njem. Schwalier & \multirow[t]{2}{*}{ - (1.) ljubavnik ${ }^{158}$} \\
\hline & $\begin{array}{l}\text { reg. ekspr. 1. ljubavnik; } 2 . \\
\text { zavodnik, ženskar }\end{array}$ & \\
\hline \multirow[t]{2}{*}{$\begin{array}{l}\text { Oj vi nene }{ }^{159} \text {, što se ne udate, } \\
\text { što vi nama kolo ne pridate. }\end{array}$} & $\begin{array}{l}\text { postanje nepoznato, no vjerojatno u } \\
\text { vezi s grč. Helena: sjaj, blistavost } \\
\text { (izvedenica) }\end{array}$ & \multirow[t]{2}{*}{$\begin{array}{l}\text { - starija neudana } \\
\text { djevojka } \\
\text { novo značenje }\end{array}$} \\
\hline & reg. 1. starija sestra & \\
\hline \multirow{2}{*}{$\begin{array}{l}\text { Alaj braca na me oko baca, } \\
\text { ljubio b' me, al' nema novaca. }\end{array}$} & prasl. i stsl. bratrı (izvedenica) & \multirow{2}{*}{$\begin{array}{l}\text { - mladić, muškarac } \\
\text { (općenito) } \\
\text { metonimija novo } \\
\text { značenje }\end{array}$} \\
\hline & $\begin{array}{l}\text { 1. muškarac drugoj osobi koja je } \\
\text { rođena od istih roditelja; 2. term. } \\
\text { pripadnik neke organizacije prema } \\
\text { drugim pripadnicima; 3. } \text { kat. }\end{array}$ & \\
\hline
\end{tabular}

${ }^{158}$ Klaić (2002: 1315) tumači da je leksem švaler franc. porijekla „chevalier - prvotno konjanik, vitez, kasnije kavalir“ što je značenjski udaljeno od značenja koje ima leksem u danom kontekstu dvostiha. Bilo bi zanimljivo proučiti kako se i kada to prvotno značenje nijansiralo u 'ljubavnik, milosnik, dragan; ženskar, lola'.

${ }^{159}$ Anić ne bilježi navedeni leksem dok Janković (1974: 135) objašnjava da „Mlađa sestra naziva stariju nenom. Ovdje to znači starije neudate djevojke.“" 


\begin{tabular}{|c|c|c|}
\hline & $\begin{array}{l}\text { redovnici u međusobnom } \\
\text { obraćanju; 4. pren. prijatelj, drug }\end{array}$ & \\
\hline \multirow[t]{2}{*}{$\begin{array}{l}\text { Diko moja, mirisavo grožđe, } \\
\text { ljubit ću te ma dobio gvožđe. }\end{array}$} & $\begin{array}{l}\text { prasl. gvozdьje od prasl. i stsl. } \\
\text { gvozdь }\end{array}$ & \multirow{2}{*}{$\begin{array}{l}\text { - (2.) b. pren. } \\
\text { okovi, odnosno } \\
\text { kaznu, zatvor }\end{array}$} \\
\hline & $\begin{array}{l}\text { 1. jez. knjiž. razg. (+ srp.) željezo; } \\
\text { 2. (mn.) a. v. klopka, b. pren. okovi }\end{array}$ & \\
\hline \multirow{2}{*}{$\begin{array}{l}\text { Oj inočo, pukni ko mauna, } \\
\text { kad te dika drži za majmuna. }\end{array}$} & tur. maymun & \multirow{2}{*}{$\begin{array}{l}\text { - (2.) pren. pejor. } \\
\text { b. koji je glup }\end{array}$} \\
\hline & $\begin{array}{l}\text { 1. zool. čovjekoliki sisavac iz reda } \\
\text { Primates; 2. pren. pejor. a. onaj } \\
\text { koji oponaša koga ili što kao } \\
\text { majmun, b. koji je glup; 3. int. } \\
\text { žarg. znak @ }\end{array}$ & \\
\hline \multirow{2}{*}{$\begin{array}{l}\text { Oj inočo, što si se nadula, } \\
\text { ko našega paroka tambura? }\end{array}$} & tur. tanbur & \multirow{2}{*}{$\begin{array}{l}\text { - trbuh } \\
\text { preneseno novo } \\
\text { značenje }\end{array}$} \\
\hline & $\begin{array}{l}\text { 1. glazb. tradicionalno, ali ne i } \\
\text { autohtono narodno žičano glazbalo, } \\
\text { svira se trzalicom }\end{array}$ & \\
\hline \multirow{2}{*}{$\begin{array}{l}\text { Volio me, a sada se brani, } \\
\text { uvenio ko lišće na grani. }\end{array}$} & prasl. borniti & \multirow{2}{*}{$\begin{array}{l}\text { - (2.) pren. b. } \\
\text { opravdavati se }\end{array}$} \\
\hline & $\begin{array}{l}\text { 1. (koga, što) a. štiti koga od } \\
\text { napada, opasnosti, b. biti čiji } \\
\text { branitelj, c. zastupati, zagovarati } \\
\text { neko mišljenje; 2. (komu, što) ne } \\
\text { dopuštati, zabranjivati; 3. (se) a. } \\
\text { pružati otpor, opirati se, a. braniti } \\
\text { se očajnički od čega, b. pren. } \\
\text { izbjegavati što svim sredstvima, b. } \\
\text { opravdavati se }\end{array}$ & \\
\hline \multirow{2}{*}{$\begin{array}{l}\text { Alaj mi je i pristalo mi je, } \\
\text { poljubiti mlađe } i \text { starije. }\end{array}$} & pri- + prasl. i stsl. stati (tvorenica) & \multirow{2}{*}{$\begin{array}{l}\text { - odgovarati, } \\
\text { priličiti } \\
\text { novo značenje }\end{array}$} \\
\hline & $\begin{array}{l}\text { 1. (na što) dati pristanaka, prihvatiti } \\
\text { čiji prijedlog; 2. (za kim) poći, } \\
\text { krenuti za kim; 3. zaustaviti se uz } \\
\text { obalu, uz kraj }\end{array}$ & \\
\hline Mene cure zlobu pored blaga, & od blag (prasl. bolgъ) & \\
\hline
\end{tabular}




\begin{tabular}{|c|c|c|}
\hline $\begin{array}{l}\text { zalud im je, kad sam svakom } \\
\text { draga. }\end{array}$ & $\begin{array}{l}\text { 1. velika vrijednost u novcu, zlatu i } \\
\text { dragocjenostima; 2. pren. duhovno, } \\
\text { kulturno i drugo dobro; 3. stoka, } \\
\text { marva }\end{array}$ & $\begin{array}{l}\text { - draga osoba, } \\
\text { dragi/draga } \\
\text { preneseno novo } \\
\text { značenje }\end{array}$ \\
\hline \multirow{2}{*}{$\begin{array}{l}\text { Čekaj diko još godinu dana, } \\
\text { još me nije nakitila mama. }\end{array}$} & prasl. kyta & \multirow[b]{2}{*}{$\begin{array}{l}\text { - uresila, tj. } \\
\text { opremila } \\
\text { „imovinom“, } \\
\text { nasljedstvom, tzv. } \\
\text { mirazom } \\
\text { preneseno novo } \\
\text { značenje }\end{array}$} \\
\hline & $\begin{array}{l}\text { 1. (koga, što) v. kititi; 2. (se) žarg. } \\
\text { opiti se alkoholnih pića; naljoskati } \\
\text { se } \\
\text { kititi => 1. stavljanjem ukrasa činiti } \\
\text { da tko bude ljepši; 2. pren. dodavati } \\
\text { u pričanju više nego što treba }\end{array}$ & \\
\hline \multirow{2}{*}{$\begin{array}{l}\text { Alaj sam se dike navarala, } \\
\text { oko mene 'oda zabadava. }\end{array}$} & za- + tur. bedava (tvorenica) & \multirow{2}{*}{$\begin{array}{l}\text { - (2.) bez učinka; } \\
\text { uzalud }\end{array}$} \\
\hline & $\begin{array}{l}\text { reg. 1.a. bez nagrade ili naplate; } \\
\text { besplatno, b. vrlo jeftino; } 2 \text {. bez } \\
\text { učinka; uzalud }\end{array}$ & \\
\hline \multirow{2}{*}{$\begin{array}{l}\text { Ni me meštar naučio škole, } \\
k^{\prime} \text { š to me je milo janje moje }{ }^{160} \text {. }\end{array}$} & njem. Meister & \multirow[t]{2}{*}{ - (2.) učitelj } \\
\hline & $\begin{array}{l}\text { reg. 1.a. majstor u svom poslu, b. } \\
\text { prema mediteranskim običajima, } \\
\text { riječ za oslovljavanje obrtnika; } 2 . \\
\text { učitelj }\end{array}$ & \\
\hline \multirow{2}{*}{$\begin{array}{l}\text { Ženit ću se, al' neću iz sela, } \\
\text { već iz Zbjega ja i moj kolega. }\end{array}$} & lat. collega & \multirow{2}{*}{$\begin{array}{l}\text { - prijatelj } \\
\text { novo značenje }\end{array}$} \\
\hline & $\begin{array}{l}\text { 1. drug po učenju ili zanimanju; } 2 . \\
\text { riječ kojom se oslovljava u nekim } \\
\text { zanimanjima; 3. u akademskim } \\
\text { krugovima obraćanje starijega } \\
\text { mlađemu ili međusobno } \\
\text { oslovljavanje ravnopravnih }\end{array}$ & \\
\hline \multirow{2}{*}{$\begin{array}{l}\text { Uzmi curu, koja imala tala }{ }^{161} \text {, } \\
\text { makar bila gurava i mala. }\end{array}$} & njem. Teil & \multirow{2}{*}{$\begin{array}{l}\text { - (2.) dio } \\
\text { nasljedstva, miraz }\end{array}$} \\
\hline & $\begin{array}{l}\text { 1. dio, udio; 2. dio nasljedstva, } \\
\text { miraz }\end{array}$ & \\
\hline
\end{tabular}

160 Janković (1967: 155) navodi zanimljivu opasku uz zabilježeni stih: „Znam dosta Šokica koje su se dale podučavati od meštra i u ljubavi.“

${ }^{161}$ Značenja ovog leksema nisu zabilježena u Anićevu rječniku dok Skok (1973: 437) navodi samo prvo značenje. 


\begin{tabular}{|c|c|c|}
\hline $\begin{array}{l}\text { ja ću s dikom kleknuti kod } \\
\text { oltara. }\end{array}$ & & \\
\hline \multirow{2}{*}{$\begin{array}{l}\text { Alaj imam komšiju šilboka, } \\
\text { sam šilboči, ko će k meni doći. }\end{array}$} & njem. Schildwache (straža) & \multirow{2}{*}{$\begin{array}{l}\text { - uhoda, onaj kojeg } \\
\text { zanima sve, } \\
\text { sveznalica } \\
\text { preneseno novo } \\
\text { značenje }\end{array}$} \\
\hline & $\begin{array}{l}\text { reg. vojn. zast. ekspr. bajonet, } \\
\text { bajunet }^{162}\end{array}$ & \\
\hline \multirow{2}{*}{$\begin{array}{l}\text { Alaj sam se narumenisala, } \\
\text { tri sam momka obegenisala. }\end{array}$} & tur. beğendi & \multirow{2}{*}{$\begin{array}{l}\text { - privući, osvojiti, } \\
\text { zaludjeti } \\
\text { novo značenje }\end{array}$} \\
\hline & $\begin{array}{l}\text { reg. 1. svidjeti se; 2. suglasan biti s } \\
\text { čim; odobriti; 3. (po)hvaliti, istaći }\end{array}$ & \\
\hline \multirow[t]{2}{*}{$\begin{array}{l}\text { Diko moja, lipo se ušniraj, } \\
\text { pa kraj moga dvora } \\
\text { prošpanciraj. }\end{array}$} & $\begin{array}{l}\text { u- '+ njem. (ein)schnüren } \\
\text { (pritegnuti - tvorenica) }\end{array}$ & \multirow{2}{*}{$\begin{array}{l}\text { - urediti se, lijepo } \\
\text { se obući } \\
\text { preneseno novo } \\
\text { značenje }\end{array}$} \\
\hline & $\begin{array}{l}\text { reg. zast. uvesti vrpcu u što kako bi } \\
\text { se priteglo }\end{array}$ & \\
\hline \multirow{2}{*}{$\begin{array}{l}\text { Ja ću svoju diku zaularit, } \\
\text { on će spavat, ja ću se bećarit. }\end{array}$} & za- + tur. yular (tvorenica) & \multirow{2}{*}{$\begin{array}{l}\text { - (2.) pren. nekoga } \\
\text { podčiniti svojoj } \\
\text { volji; zauzdati }\end{array}$} \\
\hline & $\begin{array}{l}\text { reg. 1. staviti ular na konja; } 2 \text {. pren. } \\
\text { nekoga podčiniti svojoj volji; } \\
\text { zauzdati }\end{array}$ & \\
\hline \multirow{2}{*}{$\begin{array}{l}\text { Stara diko, žao mi je tebe, } \\
\text { što s nevoljom moraš leć pod } \\
\text { ćebe. }\end{array}$} & ne-+ prasl. i stsl. volja (tvorenica) & \multirow{2}{*}{$\begin{array}{l}\text { - nevoljena žena } \\
\text { preneseno novo } \\
\text { značenje }\end{array}$} \\
\hline & $\begin{array}{l}\text { 1. zlo, nesreća, bijeda; 2. nužda, } \\
\text { potreba; 3. pejor. onaj koji je } \\
\text { bijedan; jadnik, nesretnik, } \\
\text { siromašak }\end{array}$ & \\
\hline \multirow{2}{*}{$\begin{array}{l}\text { Žao mi je moga lole tila, } \\
\text { što će leći kraj toga fitilja. }\end{array}$} & tur. fitil & \multirow{2}{*}{$\begin{array}{l}\text { - sitna, mršava žena } \\
\text { pejorativno } \\
\text { preneseno novo } \\
\text { značenje }\end{array}$} \\
\hline & $\begin{array}{l}\text { 1. nit od upredenih pamučnih } \\
\text { vlakana u svijeći; žižak; 2.a. } \\
\text { upaljač starinskih topova i pušaka, } \\
\text { b. upaljač na nekim eksplozivnim } \\
\text { napravama; 3. pren. poticaj, povod, } \\
\text { uzrok }\end{array}$ & \\
\hline Alaj prija ima mušterija: & tur. müşteri & \\
\hline
\end{tabular}

162 Za razliku od navedene Anićeve natuknice leksema, izvedeno novo značenje može se oblikovati po natuknici koju navodi Klaić (2002: 1294) 'stražar, čuvar, pazitelj'. 


\begin{tabular}{|c|c|c|}
\hline sinoć sedam, a danas nijedan. & $\begin{array}{l}\text { reg. 1. onaj koji se koristi uslugama } \\
\text { trgovaca ili obrtnika; kupac; } 2 . \\
\text { pren. iron. a. onaj koji naivno } \\
\text { kupuje nešto bezvrijedno ili ne } \\
\text { shvaća prijevare, b. sport iron. onaj } \\
\text { koji stalno gubi utakmice }\end{array}$ & $\begin{array}{l}\text { - prosac, udvarač }{ }^{163} \\
\text { preneseno novo } \\
\text { značenje }\end{array}$ \\
\hline \multirow{2}{*}{$\begin{array}{l}\text { Sinoć mi se jedna globa javlja, } \\
\text { Ja tu globu ljubiti ne mogu. }\end{array}$} & globa od prasl. globiti (izvedenica) & \multirow{2}{*}{$\begin{array}{l}\text { - } \text { mršavica }^{164} \\
\text { pejorativno } \\
\text { preneseno novo } \\
\text { značenje }\end{array}$} \\
\hline & $\begin{array}{l}\text { 1. sudska ili upravna novčana } \\
\text { kazna; 2. svota koja se plaća za } \\
\text { učinjeni prekršaj }\end{array}$ & \\
\hline $\begin{array}{l}\text { Lako mi je s drugim govoriti, } \\
\text { lola mlada, pa je moja vlada. }\end{array}$ & prasl. voldati & $\begin{array}{l}\text { - odluka, riječ } \\
\text { preneseno novo } \\
\text { značenje }\end{array}$ \\
\hline $\begin{array}{l}\text { Mila moja, pošteno se vladaj, } \\
\text { ide jesen, kući mi se nadaj. }\end{array}$ & $\begin{array}{l}\text { vlada => 1. najviši organ izvršne } \\
\text { vlasti neke države; } 2 \text {. razg. takav } \\
\text { organ svake političko- } \\
\text { administrativne jedinice; 3.a. } \\
\text { vladanje, gospodarenje, b. vlast, } \\
\text { vladavina } \\
\text { vladati => 1.a. upravljati državom, } \\
\text { b. imati vlast nad kim ili čim; 2.a. } \\
\text { isticati se, dominirati, b. baratati, } \\
\text { rukovati, znati upotrebljavati, c. } \\
\text { širiti se, biti raširen, harati; 3.a. } \\
\text { ponašati se, b. upravljati se, ravnati } \\
\text { se prema čemu }\end{array}$ & $\begin{array}{l}\text { - (3.) a. ponašati se } \\
\text { primjereno, biti } \\
\text { dobra, vjerna }{ }^{165}\end{array}$ \\
\hline \multirow{2}{*}{$\begin{array}{l}\text { Alaj mi se okovalo lane, } \\
\text { zbog 'ne svoje nerođene mame. }\end{array}$} & o- + prasl. i stsl. kovati (tvorenica) & \multirow{2}{*}{$\begin{array}{l}\text { - obećati se kome, } \\
\text { oženiti se/udati se } \\
\text { preneseno novo } \\
\text { značenje }\end{array}$} \\
\hline & $\begin{array}{l}\text { 1. staviti kome okove; } 2 \text { obložiti } \\
\text { što kovanim plemenitim metalom; } \\
\text { 3. pren. sputati koga u slobodi } \\
\text { mišljenja, rada i djelovanja }\end{array}$ & \\
\hline
\end{tabular}

${ }^{163}$ Klaić (2002: 919) leksemu mušterija pronalazi pet značenja od koji četvrto odgovara značenju koje ima leksem u danom kontekstu dvostiha: '4. iz značenja 1. i 2. razvilo se značenje: prosac, udvarač, zaručnik, tj. onaj koji hoće djevojku'.

164 Janković (1974: 135) leksem globa pojašnjava značenjem: „Globa je kost bez mesa (i to veća kost). Neće mršavu“ što se može povezati s leksemom globiti i njegovom značenjskom nijansom 'naplaćivati cijenu za što; derati, guliti, izrabljivati' koja upućuje na ogoljenost, a prema tome i na ženu koja nema 'mesa', koja je mršava. ${ }^{165}$ Iz konteksta se može iščitati da ju podsjeća na nadolazeće vjenčanje i na vjernost na koju mu se obvezala. 


\begin{tabular}{|c|c|c|}
\hline \multirow[t]{2}{*}{$\begin{array}{l}\text { Čaša vina i curica fina, } \\
\text { to je mojem tilu medecina. }\end{array}$} & $\begin{array}{l}\text { lat. medicina (ars): iscjeliteljsko, } \\
\text { liječničko umijeće }\end{array}$ & \multirow[t]{2}{*}{$\begin{array}{l}\text { - (4.) razg. zast. } \\
\text { lijek }\end{array}$} \\
\hline & $\begin{array}{l}\text { 1. znanost; 2. način liječenja,, } \\
\text { medicinska praksa; 3. profesija } \\
\text { liječnika; 4. razg. zast. lijek }\end{array}$ & \\
\hline \multirow{2}{*}{$\begin{array}{l}\text { Golub guče na jelovoj grane, } \\
\text { diko moja, na kojoj si strane. }\end{array}$} & prasl. storna: strana, zemlja & \multirow{2}{*}{$\begin{array}{l}\text { - (6.) pren. } \\
\text { shvaćanje, gledište, } \\
\text { stajalište }\end{array}$} \\
\hline & $\begin{array}{l}\text { 1. granična površina nekog tijela ili } \\
\text { granična crta neke površine; } 2 \text {. lice } \\
\text { i naličje predmeta; 3. mat. ploha; } 4 \text {. } \\
\text { kraj, predio; 5. dio od vrha do } \\
\text { podnožja brda; strmina; } 6 \text {. pren. } \\
\text { shvaćanje, gledište, stajalište; } 7 . \\
\text { pojedinac ili kolektiv koji se bori za } \\
\text { što; 8. linija, grana srodstva; } 9 . \\
\text { svojstvo }\end{array}$ & \\
\hline \multirow{2}{*}{$\begin{array}{l}\text { Pisala mi dika iz Osika, } \\
\text { da će doći kad bude sonika. }\end{array}$} & prasl. sblnьce & \multirow{2}{*}{$\begin{array}{l}\text { - (2.) meton. } \\
\text { Sunčeva svjetlost i } \\
\text { toplina }\end{array}$} \\
\hline & $\begin{array}{l}\text { 1.a. Zemlji najbliža zvijezda i } \\
\text { središnje nebesko tijelo Sunčeva } \\
\text { sustava, b. središnje zvijezde } \\
\text { drugih kozmičkih sustava; } 2 \text {. } \\
\text { meton. Sunčeva svjetlost i toplina; } \\
\text { 3. fam. draga osoba }\end{array}$ & \\
\hline \multirow{2}{*}{$\begin{array}{l}\text { Što ostalo, ono druge kupe, } \\
\text { za me nema dorana u župe. }\end{array}$} & tur. doru at: mrki konj & \multirow{2}{*}{$\begin{array}{l}\text { - mladić } \\
\text { preneseno novo } \\
\text { značenje }\end{array}$} \\
\hline & $\begin{array}{l}\text { reg. konj tamnoriđe boje; doro, } \\
\text { dorko, dorin, dorija }\end{array}$ & \\
\hline \multirow{2}{*}{$\begin{array}{l}\text { Upro mjesec u moje kiljere, } \\
\text { Ge sam svoje školovala dere. }\end{array}$} & tal. scola < lat. (izvedenica) & \multirow{2}{*}{$\begin{array}{l}\text { - učiti koga } \\
\text { ljubavnome } \\
\text { umijeću } \\
\text { preneseno novo } \\
\text { značenje }\end{array}$} \\
\hline & $\begin{array}{l}\text { 1. (koga) slati na pohađanje škole; } \\
\text { financirati školovanje; } 2 \text {. (se) } \\
\text { pohađati školu; obrazovati se }\end{array}$ & \\
\hline A šta mi se garava nameće, & prasl. garb (izvedenica) & \\
\hline
\end{tabular}




\begin{tabular}{|c|c|c|}
\hline kad garava moje srce neće. & $\begin{array}{l}\text { 1. koja je uprljana čađu; čađava; } 2 \text {. } \\
\text { pren. razg. fam. koja je crne kose ili } \\
\text { dlake; crnomanjasta }\end{array}$ & $\begin{array}{l}\text { - (2.) pren. razg. } \\
\text { fam. koja je crne } \\
\text { kose ili dlake; } \\
\text { crnomanjasta }\end{array}$ \\
\hline \multirow{2}{*}{$\begin{array}{l}\text { Umri skotu, da ljubim lipotu, } \\
\text { da lipota ne gine kraj skota. }\end{array}$} & prasl. skotb & \multirow{2}{*}{$\begin{array}{l}\text { - (2.) pren. pejor. } \\
\text { zla, nemilosrdna, } \\
\text { podla osoba }\end{array}$} \\
\hline & $\begin{array}{l}\text { 1. ekspr. ono što se okotilo; } \\
\text { životinja; živinče; 2. pren. pejor. } \\
\text { zla, nemilosrdna, podla osoba }\end{array}$ & \\
\hline \multirow{4}{*}{$\begin{array}{l}\text { Kad obučem svilene rukave, } \\
\text { svit mi kaže: ,gle, gospoje } \\
\text { prave." }\end{array}$} & prasl. i stsl. rǫa & \multirow{4}{*}{$\begin{array}{l}\text { - gornji dio ženske } \\
\text { nošnje (svileni } \\
\text { oplećak) } \\
\text { metonimija novo } \\
\text { značenje } \\
\text { - dama, žena sa } \\
\text { stilom } \\
\text { novo prošireno } \\
\text { značenje }\end{array}$} \\
\hline & $\begin{array}{l}\text { 1. dio odjeće koji pokriva ruku; 2.a. } \\
\text { v. rukavac, b. nešto što se grana, } \\
\text { odvaja od svojeg glavnog dijela; } \\
\text { ogranak, krak }\end{array}$ & \\
\hline & prasl. gostьpodь & \\
\hline & $\begin{array}{l}\text { 1. reg. gospođa, usp. gospa }{ }^{166} ; 2 . \\
\text { pejor. ona koja izigrava gospođu, } \\
\text { ona koja razmetanjem pokazuje da } \\
\text { je gospođa }\end{array}$ & \\
\hline \multirow[t]{2}{*}{$\begin{array}{l}\text { Stara diko, tri ti tvoje mame, } \\
\text { nemoj više zapinjati za me. }\end{array}$} & $\begin{array}{l}\text { za- + na- + prasl. i stsl. pęti } \\
\text { (tvorenica) }\end{array}$ & \multirow{2}{*}{$\begin{array}{l}\text { - zanimati se za } \\
\text { koga } \\
\text { preneseno novo } \\
\text { značenje }\end{array}$} \\
\hline & $\begin{array}{l}\text { zapeti => 1. (što) namjestiti da se } \\
\text { zadrži ono što teži da se vrati u } \\
\text { prvobitni položaj; 2.a. naići na } \\
\text { prepreku; stati, b. zaplesti se u } \\
\text { govoru, zamucati; 3. napregnuti se, } \\
\text { upotrijebiti svu snagu; } 4 \text {. } \\
\text { tvrdoglavo ostati pri svom } \\
\text { mišljenju }\end{array}$ & \\
\hline U devojke oko vrata lanci, & prasl. lanьсь & \\
\hline
\end{tabular}

${ }^{166}$ Leksem ima četiri značenja: '1. knjiš. arh. jez. knjiž. dama, gospođa; 2. riječ za oslovljavanje žene iz nižih slojeva; 3. kat. Blažena Djevica Marija; 4. lokal. blagva'. Prvo značenje moglo bi odgovarati značenju koje ima leksem u danome kontekstu dvostiha. 


\begin{tabular}{|c|c|c|}
\hline a u oca traljavi opanci. & $\begin{array}{l}\text { 1. niz spojenih metalnih karika; } 2 \text {. } \\
\text { tehn. niz drugačijih članova } \\
\text { spojenih na razne načine u gibljivu } \\
\text { cjelinu; 3. niz u kojem se razabiru } \\
\text { jedinke; 4. niz poduzeća, } \\
\text { prodavaonica i sl. istoga vlasnika; } \\
\text { 5. pov. mjera za površinu zemlje; } \mathbf{6} \text {. } \\
\text { okovi }\end{array}$ & $\begin{array}{l}\text { - uporabni predmet } \\
\text { kao nakit } \\
\text { preneseno } \\
\text { pejorativno novo } \\
\text { značenje }\end{array}$ \\
\hline \multirow{4}{*}{$\begin{array}{l}\text { Koga mogu kupit za posije } e^{167} \text {, } \\
\text { s onim neću vodit komesije. }\end{array}$} & po- + prasl. sĕti, sĕati (tvorenica) & \multirow{4}{*}{$\begin{array}{l}\text { - jeftina stvar, mala } \\
\text { ili nikakva } \\
\text { vrijednost čega } \\
\text { preneseno novo } \\
\text { značenje } \\
\text { - pregovori, } \\
\text { razgovori, dogovori } \\
\text { prošireno novo } \\
\text { značenje }\end{array}$} \\
\hline & $\begin{array}{l}\text { 1. mekinje (ljuske samljevenog } \\
\text { zrnja žita koje se sijanjem odvajaju } \\
\text { od brašna) }\end{array}$ & \\
\hline & lat. committere (povjeriti) & \\
\hline & $\begin{array}{l}\text { 1. privremeno ili stalno vijeće, } \\
\text { povjerenstvo; } 2 \text {. ugovor prema } \\
\text { kojem se jedna stranka obvezuje da } \\
\text { ce po nalogu druge stranke izvršiti } \\
\text { jedan ili više ugovora u svoje } \\
\text { ime }^{168}\end{array}$ & \\
\hline \multirow{2}{*}{$\begin{array}{l}\text { Diko moja, dobi' glas od tebe, } \\
\text { da si danas naružio mene. }\end{array}$} & prasl. golsъ & \multirow[t]{2}{*}{ - (4.) vijest, novost } \\
\hline & $\begin{array}{l}\text { 1. učinak rada govornih organa; } 2 \text {. } \\
\text { glazb. visina tona u pjevanju; } \mathbf{3} \text {. } \\
\text { mišljenje drugih o kome; } \mathbf{4} \text {. vijest, } \\
\text { novost; 5. pojedinačno } \\
\text { izjašnjavanje u odlučivanju ili na } \\
\text { izborima; 6. lingv. najmanja } \\
\text { govorna jedinica }\end{array}$ & \\
\hline \multirow{2}{*}{$\begin{array}{l}\text { Ne udaju curu ni ormani, } \\
\text { nego zemlja, ma bili frtalji. }\end{array}$} & srlat. armarium & \multirow{2}{*}{$\begin{array}{l}\text { - odjeća, imetak u } \\
\text { nošnji }\end{array}$} \\
\hline & $\begin{array}{l}\text { 1. dio pokućstva s vratima u kojem } \\
\text { se drži rublje, odjeća i sl. }\end{array}$ & \\
\hline
\end{tabular}

${ }^{167}$ Skok (1973: 518) također definira leksem posije kao „ono što se iz pljeve na protak protoči, samelje se i zimi služi krmcima za hranu“. Pljeva je ostatak žitnog zrnja, tzv. otpadak te služi svinjama za hranu što može u prenesenome smislu značenjski odgovarati novome značenju koje ima leksem u danome kontekstu dvostiha. ${ }_{168}$ Značenja su rječničke jedinice navedena po Klaiću (2002). Anić (2003) slično definira značenja, no bilježi i drugo značenje 'posredništvo, komision'. 


\begin{tabular}{|c|c|c|}
\hline & & $\begin{array}{l}\text { metonimija novo } \\
\text { značenje }\end{array}$ \\
\hline \multirow{3}{*}{$\begin{array}{l}\text { Kiša pada-Srbija propada, } \\
\text { Sunce sija, pa će i Rusija }{ }^{169} \text {. }\end{array}$} & geogr. 1. područje srpskoga naroda & \multirow{2}{*}{$\begin{array}{l}\text { - vojnici, tj. vojska } \\
\text { Srbije, Rusije i } \\
\text { Crne Gore } \\
\text { metonimija novo } \\
\text { značenje }\end{array}$} \\
\hline & određeno različitim državnim & \\
\hline & granicama u raznim državnim & $\begin{array}{l}\text { Crne Gore } \\
\text { metonimija novo } \\
\text { značenje }\end{array}$ \\
\hline \multirow{10}{*}{$\begin{array}{l}\text { Crna gora }{ }^{170} \text { predala se sama, } \\
\text { al Rusija ne smije od srama. }\end{array}$} & & \multirow{10}{*}{$\begin{array}{l}\text { metonimija novo } \\
\text { značenje }\end{array}$} \\
\hline & jedinica Savezne Republike & \\
\hline & Jugoslavije, gl. grad Beograd & \\
\hline & postanje nepoznato, no vjerojatno u & \\
\hline & vezi s prasl. rusъ (svijetlosmeđ) & \\
\hline & geogr. 1. pov. zemlja i državna & \\
\hline & tvorevina u kojoj pretežno žive & \\
\hline & $\begin{array}{l}\text { Rusi; 2. pol. Ruska Federacija, gl. } \\
\text { grad Moskva }\end{array}$ & \\
\hline & $\begin{array}{l}\text { postanje nepoznato, no vjerojatno u } \\
\text { vezi s prasl. čsrnъ }+ \text { prasl. i stsl. } \\
\text { gora }\end{array}$ & \\
\hline & $\begin{array}{l}\text { geogr. Federalna jedinica SRJ, gl. } \\
\text { grad Cetinje }\end{array}$ & \\
\hline \multirow{3}{*}{$\begin{array}{l}\text { Mene moji u Srbiju daju, } \\
\text { Pa su ošli kuću da gledaju. }\end{array}$} & postanje nepoznato & \multirow{2}{*}{$\begin{array}{l}\text { - Srbin } \\
\text { metonimija novo } \\
\text { značenje }\end{array}$} \\
\hline & $\begin{array}{l}\text { geogr. 1. područje srpskoga naroda } \\
\text { određeno različitim državnim } \\
\text { granicama u raznim državnim } \\
\text { organizacijama; 2. federalna } \\
\text { jedinica Savezne Republike } \\
\text { Jugoslavije, gl. grad Beograd }\end{array}$ & \\
\hline & $\begin{array}{l}\text { postanje nepoznato, no vjerojatno u } \\
\text { vezi sa s- + prasl. běgь // prasl. } \\
\text { šumъ }\end{array}$ & $\begin{array}{l}\text { - stanovnici sela } \\
\text { metonimija novo } \\
\text { značenje }\end{array}$ \\
\hline
\end{tabular}

${ }^{169}$ Stih opisuje prilike u svijetu i u Slavoniji koje su se zbile za vrijeme Prvoga svjetskog rata te cjelokupno oduševljenje koje je vladalo kad je stigla vijest da je Austro-Ugarska svladala Srbiju, a da za njezinom sudbinom ide i velika Rusija u kojoj su kao vojnici poslani brojni Slavonci i Baranjci. Više o tome u Barišić (2016: 117134).)

${ }^{170}$ Zabilježba toponima donosi se kako je i u originalu rukopisa Luke Lukića. 


\begin{tabular}{|c|c|c|}
\hline $\begin{array}{l}\text { Nek se složi i } \text { Zbjeg }^{171} i \\
\text { Šmeće, } \\
\text { mene s dikom rastaviti neće. }\end{array}$ & $\begin{array}{l}\text { geogr. naseljena mjesta u općini } \\
\text { Bebrina, u Brodsko-posavskoj } \\
\text { županiji }\end{array}$ & \\
\hline \multirow{2}{*}{$\begin{array}{l}\text { Maramica sa opšlingom bilim, } \\
\text { doveče ću s lolom da se dilim. }\end{array}$} & prasl. dělı & \multirow{2}{*}{$\begin{array}{l}\text { - rastajati se } \\
\text { preneseno novo } \\
\text { značenje }\end{array}$} \\
\hline & $\begin{array}{l}\text { 1.a. raščlanjivati na manje komade, } \\
\text { b. } \text { mat. izvoditi operaciju dijeljenja, } \\
\text { c. zajednički koristiti, } \\
\text { upotrebljavati; 2. davati (što) od } \\
\text { nečega većeg; 3. razgraničavati se u } \\
\text { pravima na neko imanje ili imovinu }\end{array}$ & \\
\hline \multirow{2}{*}{$\begin{array}{l}\text { Ja sam bećar }{ }^{172} \text { i bećarska } \\
\text { lola, } \\
\text { kog poljubim, bolovati mora. }\end{array}$} & tur. bekār & \multirow{2}{*}{$\begin{array}{l}\text { - (2.) veseljak, } \\
\text { sklon piću, jelu, } \\
\text { veselju i ženama }\end{array}$} \\
\hline & $\begin{array}{l}\text { reg. 1. mlađi neženja, momak, } \\
\text { samac; 2. veseljak, sklon piću, jelu, } \\
\text { veselju i ženama; bekrija, lola }\end{array}$ & \\
\hline \multirow{2}{*}{$\begin{array}{l}\text { Žuta kuća i na njoj skaline, } \\
\text { nije moje lice za fakine. }\end{array}$} & tal. facchino & \multirow{2}{*}{$\begin{array}{l}\text { - (1.) onaj koji radi } \\
\text { sitne nepodopštine; } \\
\text { berekin, deran, } \\
\text { mangup }\end{array}$} \\
\hline & $\begin{array}{l}\text { 1. onaj koji radi sitne nepodopštine; } \\
\text { berekin, deran, mangup; 2. reg. } \\
\text { nosač, služnik, poslužitelj, trhonoša }\end{array}$ & \\
\hline \multirow{2}{*}{$\begin{array}{l}\text { Mogu biti pomodna i fina, } \\
\text { kad mi lola misečinu }{ }^{173} \text { prima. }\end{array}$} & prasl. i stsl. mĕsęcь (izvedenica) & \multirow{2}{*}{$\begin{array}{l}\text { - (2.) stalna, } \\
\text { sigurna mjesečna } \\
\text { plaća }\end{array}$} \\
\hline & $\begin{array}{l}\text { 1. fiziol., v. menstruacija; 2. stalna, } \\
\text { sigurna mjesečna plaća }\end{array}$ & \\
\hline \multirow{2}{*}{$\begin{array}{l}\text { Cili dan čoban kod ovaca } \\
\text { drema, } \\
\text { kad uveče, ljubio b' a nema. }\end{array}$} & tur. çoban & \multirow{2}{*}{$\begin{array}{l}\text { - (1.) onaj koji čuva } \\
\text { stoku na paši }\end{array}$} \\
\hline & $\begin{array}{l}\text { 1. onaj koji čuva stoku na paši; } \\
\text { pastir; 2. onaj koji napasa stoku na } \\
\text { nomadski način; 3. pejor. onaj koji }\end{array}$ & \\
\hline
\end{tabular}

${ }^{171}$ Leksem je toponim i kao takav nije zaveden u rječniku. Nije značenjski vezan uz natuknice koje navodi Anić: '1. mjesto gdje je više ljudi našlo utočište od opasnosti; 2. meton. oni koji su u zbjegu, oni koji su se zbježali'. Drugi je leksem Šumeće definiran kao 'naselje (u blizini Slavonskog Broda), 602 stan.'.

172 Janković (1974: 95) bilježi da „Ta arapska riječ znači 'čovjek koji nema ni žene, ni kuće, ni kućišta, te živi od nadnice. Dakle neoženjeni beskućnik (jangin, jump). (...) ali svakako nije u Šokadiji bećar ništa osobito ružno. (...) Iz nekih pismica bismo možda mogli pronaći glavne osobine bećara. S negativne strane on ne mora biti ni pomodar, ni pijanac, ali čini se da je skoro uvijek ženskar. (...) Obično je pomalo pomodar pa i kicoš. Također je obično i veseljak, brbljavac, šaljivac, pjevač. Vrlo često je hvalisavac, tj. ističe svoje uspjehe osobito kod žena. (...) Nikako mu nije osobina da je beskućnik i neženja niti propalica (...) Bećar može biti i oženjen čovjek, pa i bogataš, a tada je obično galantan, pa i kavaljer.'“ Skok (1971: 130) uz navedena značenja navodi još i 'vojnik za platu'.

173 Janković (1974: 118) također bilježi značenje 'mjesečna plaća' koje odgovara drugome značenju Anićeva tumačenja u Rječniku. 


\begin{tabular}{|c|c|c|}
\hline & $\begin{array}{l}\text { se ne zna ponašati, neuglađen, sirov } \\
\text { čovjek }\end{array}$ & $\begin{array}{l}\text { - ali samo kao } \\
\text { čuvar ovaca }^{174} \\
\text { suženo značenje }\end{array}$ \\
\hline \multirow{2}{*}{$\begin{array}{l}\text { Oj kako se pauraši nose, } \\
\text { duge vlase, pa ne daju na se. }\end{array}$} & njem. Bauer & \multirow[b]{2}{*}{$\begin{array}{l}\text { - stanovnici onog } \\
\text { dijela Slavonije } \\
\text { iznad Vojne } \\
\text { krajine }^{175} \\
\text { metonimija novo } \\
\text { značenje }\end{array}$} \\
\hline & $\begin{array}{l}\text { 1. reg. seljak; 2. žarg. pejor. vrlo } \\
\text { neuglađena osoba seljačkih manira; } \\
\text { seljačina }\end{array}$ & \\
\hline \multirow{2}{*}{$\begin{array}{l}\text { U mog dike pršnjak s ogledali, } \\
\text { ide šorom ko spaija mali. }\end{array}$} & tur. sipahi & \multirow{2}{*}{$\begin{array}{l}\text { - koji se hvali } \\
\text { bogatstvom }{ }^{176} \\
\text { preneseno novo } \\
\text { značenje }\end{array}$} \\
\hline & $\begin{array}{l}\text { 1. pov. posjednik timara, spahiluka } \\
\text { u Osmanskom Carstvu; dužan kao } \\
\text { konjanik ići u vojsku u slučaju rata; } \\
\text { 2. reg. zast. bolje stojeći seoski } \\
\text { domaćin - musliman u BiH }\end{array}$ & \\
\hline \multirow{2}{*}{$\begin{array}{l}\text { Moja dika velika belaja, } \\
\text { sve curice vara iz potaja. }\end{array}$} & tur. belâ & \multirow{2}{*}{$\begin{array}{l}\text { - problem, nevolja } \\
\text { preneseno novo } \\
\text { značenje }\end{array}$} \\
\hline & $\begin{array}{l}\text { reg. 1. nesreća, muka, jad, } \\
\text { neprilika; 2. (u frazemima) vrag, } \\
\text { đavo }\end{array}$ & \\
\hline \multirow{2}{*}{$\begin{array}{l}\text { A što će mi Šokac krpilonac } \\
\text { kad se meni nameće trgovac. }\end{array}$} & prasl. kъrpati + slov. lona, lonica & \multirow{2}{*}{$\begin{array}{l}\text { - } \text { siromah }^{178} \\
\text { preneseno novo } \\
\text { značenje }\end{array}$} \\
\hline & $\begin{array}{l}\text { reg. 1. putujući popravljač lonaca i } \\
\text { sl; kotlokrpa; 2. žarg. onaj koji po } \\
\text { vanjštini i ponašanju ostavlja dojam } \\
\text { najneuglednijeg društvenog sloja }\end{array}$ & \\
\hline
\end{tabular}

${ }^{174}$ Janković (1970: 67) ističe tu razliku navodeći kako „Za pastire idu i momci i djevojke u novije vrijeme. Nekad je bilo drukčije. Velike zadruge su imale poveće čopore svih vrsta marve, pa je svaku vrstu čuvao posebni pastir, koji se u svoj posao dobro razumio. Prema tome, koju su marvu čuvali, zvali su se: konjari, govedari, volari, ovčari (čobani), svinjari.“ Također i Skok (1971: 332) to strogo određuje potkrepljujući leksem sinonimom ovčar, ovčarka, ovčarica.

175 Janković (1970: 188) ističe da leksem znači „Pokadšto podrugljivo kao 'seljačina', ali kod nas za razliku od Graničara, Paorija je onaj dio Slavonije iznad Vojne Krajine. To su za Graničare bili Paori (ili paoraši).“

${ }^{176}$ Značenje više odgovara značenju koje ima leksem u danome kontekstu dvostiha, a navodi ga i sam Klaić (2002: 1253) kao '2. zemljoposjednik, feudalni posjednik zemlje, vlastelin, veleposjednik, bogat čovjek, bogataš' ne vežući se nužno uz odrednicu islama u $\mathrm{BiH}$.

177 Anić nema u Rječniku zabilježeni leksem krpilonac već bilježi leksem kotlokrpa, drotar (od njem. Draht) $\mathrm{i}$ njegovo značenje 'reg. 1. putujući popravljač lonaca i sl; kotlokrpa; 2. žarg. onaj koji po vanjštini i ponašanju ostavlja dojam najneuglednijeg društvenog sloja'.

${ }^{178}$ Značenje je leksema u danome kontekstu dvostiha izvedeno po Jankoviću (1974: 119) koji navodi da „Putujuće 'drotare' koji krpaju posuđe zovu u Šokadiji 'krpilonac'. Ovdje to ima značenje: 'siromah, koji si ne može kupiti novi lonac'." 


\begin{tabular}{|c|c|c|}
\hline \multirow[t]{2}{*}{$\begin{array}{l}\text { I sinoć sam proterao kera, } \\
\text { u sobici pokraj šifonera. }\end{array}$} & $\begin{array}{l}\text { postanje nepoznato, no vjerojatno u } \\
\text { vezi s lat. canis }\end{array}$ & \multirow{2}{*}{$\begin{array}{l}\text { - naziv za muško } \\
\text { spolovilo } \\
\text { preneseno novo } \\
\text { značenje }\end{array}$} \\
\hline & $\begin{array}{l}\text { reg. (+ srp.) 1. pas općenito; } 2 . \\
\text { lovački pas }\end{array}$ & \\
\hline \multirow{2}{*}{$\begin{array}{l}\text { Ljubila sam malo, nevaljalo, } \\
\text { pa mi moje milo zabavilo. }\end{array}$} & prasl. zabava & \multirow{2}{*}{$\begin{array}{l}\text { - negodovati, } \\
\text { odbiti, ne } \\
\text { prihvatiti }^{179} \\
\text { novo značenje }\end{array}$} \\
\hline & $\begin{array}{l}\text { 1. (koga) učiniti da tko ugodno } \\
\text { provede vrijeme; razonoditi, } \\
\text { razveseliti; 2. (koga) privući, } \\
\text { zadržati čiju pozornost; 3. (se) a. } \\
\text { ugodno provesti vrijeme; } \\
\text { proveseliti se, razonoditi se; b. } \\
\text { zadržati se, izdangubiti, provesti } \\
\text { vrijeme; c. zaposliti se čim, } \\
\text { posvetiti se čemu, uzeti u } \\
\text { razmatranje }\end{array}$ & \\
\hline
\end{tabular}

\section{$* * *$}

Provedenom se analizom pokazalo kako u deseteračkim dvostisima prevladavaju postojeća izvedena značenja polisemnih leksema. Ona su nastala tvorbom, posuđivanjem i metonimijskim i metaforičkim proširivanjem. Proces posuđivanja daleko više diktira (čak 50\%) oblikovanje postojećih izvedenih značenja pri čemu turcizmi i germanizmi dominiraju. Od praslavenskih i staroslavenskih riječi tvorbenim postupkom nastala su izvedena prenesena značenja koja čine čak jednu trećinu izvedenoga značenja zabilježenih polisemnih leksema.

$\mathrm{Za}$ analizu polisemnih leksema najzanimljiviji su oni čije su nijanse značenja izvedene kontekstom deseteračkoga dvostiha unutar kojeg se pojavljuju, a do sada nisu primjerice zabilježeni unutar Anićeva rječnika kao postojeći ili su navedeni kao monosemni leksemi. Na tim je polisemnim leksemima bio i poseban naglasak. Analiza je pokazala kako se isti mogu podijeliti u dvije skupine; leksemi novih izvedenih značenja i leksemi novih izvedenih prenesenih značenja. Prva je skupina rezultat većinom posuđivanja dok je zabilježeno i

\footnotetext{
179 Janković (1967: 159) isti glagol tumači značenjem 'negodovati, odbiti, ne prihvatiti'.
} 
nekoliko primjera nastalih tvorbom. Druga je skupina leksema nastala tvorbom, posuđivanjem i daleko više proširivanjem postojećih značenja metaforom i metonimijom.

Deseterački dvostisi svojim su sadržajem idealan tekst za proučavanje značenja postojećih polisemnih leksema kao i za proučavanje njihovih nijansiranih značenja koja uvelike ovise o kontekstu samih stihova kako je i sama analiza pokazala. Stoga, pojedine je lekseme poželjno promatrati unutar konteksta. Naglasak je kroz ovu analizu stavljen na polisemne lekseme novih izvedenih i lekseme novih izvedenih prenesenih značenja nastalih tvorbom, posuđivanjem i proširivanjem postojećih značenja metaforom i metonimijom. Analizirani izdvojeni polisemni leksemi opisanim značenjima mogu dopuniti rječničku bazu Anićeva rječnika te na taj način obogatiti i sam jezični sustav. 


\section{PRILAGODBA GERMANIZAMA I TURCIZAMA I NJIHOV UTJECAJ NA JEZIK DVOSTIHA}

Čovjek nije izolirani otok, on je društveno biće te kao takav ima potrebu i komunicirati, dijeliti svoje misli i osjećaje te prenijeti drugima svoja razmišljanja, ideje i strahove. Kroz taj apstraktni proces pošiljatelj primateljima prenosi različite poruke i istovremeno od njih može primati povratne informacije. $\mathrm{Na}$ taj način dolazi do komunikacije među sudionicima govornoga čina.

Govornici u komunikaciji kako svjesno tako i nesvjesno prenose u vlastiti jezični sustav elemente jezika s kojim dolaze u posredni ili neposredni kontakt i mijenjaju ga. Pri tom govoru određena preuzeta riječ može se dulje zadržati u međusobnoj interakciji i tako postupno prodirati sve više u jezični sustav te postati dio nove jezične sredine. Razlozi njezina zadržavanja mogu biti raznoliki - od nepronalaženja određene odgovarajuće istovrijednice posuđenice za novoimenovani predmet, stvar ili pojavu usred procvata obrta, zanatstva, gospodarstva, znanosti i tehnologije, nužnosti korištenja pojedinih riječi u procesu trgovine i proizvodnje radi lakšega i uspješnijega kupoprodajnog procesa, migracije većih skupina ljudi kao posljedice društvenih, političkih, gospodarskih i socijalnih previranja do sasvim subjektivnih razloga poput pomodarstva, osobnoga dokazivanja ili kakva drugoga razloga. Dakle, navedene promjene u jeziku nastaju pod utjecajem različitih unutarjezičnih i izvanjezičnih uvjeta, a usvojeni novi leksik odraz je ne samo jezičnih, već i društvenih i kulturnih dodira.

Svaki jezik, kao medij unutar kojeg se ostvario jezični dodir dviju kultura, ima svoje posebnosti unutar kojih čuva i dio povijesti svoga naroda i izvornoga materinskog jezika koje se prenose s generacije na generaciju, a međuljudski faktor djelovanja njegovu strukturu dodatno obogaćuje ili osiromašuje. Najbolji primjer za to su zabilježena povijesna, društvena, kulturna i socijalna događanja na području Slavonije i šire.

Područje istočne Hrvatske ${ }^{180}$ bilo je tijekom duge i bogate povijesti izloženo različitim stranim utjecajima koji su svoje tragove ostavili i u današnjemu hrvatskome jeziku. Na njega su, uz riječi arapskoga, engleskoga, francuskoga, grčkoga, latinskoga, talijanskoga i

\footnotetext{
${ }^{180}$ Misli se prvenstveno na područje Slavonije, Baranje i Srijema.
} 
mađarskoga podrijetla najviše utjecali daleko brojniji germanizmi ${ }^{181} \mathrm{i}_{\text {turcizmi }}{ }^{182} \mathrm{~s}$ kojima je stanovništvo Slavonije, Baranje i Srijema bilo u izravnome dodiru. Razloge tomu možemo tražiti u dugotrajnoj prisutnosti Osmanlija na području Slavonije s početkom od 14. stoljeća kada je hrvatski jezik došao u doticaj s osmanskim, a kasnije istjerivanjem Osmanlija u 18. stoljeću osnivanju Vojne krajine koja je služila kao vojno-redarstveno područje obrane od Osmanlija (usp. Moačanin, Valentić 1981: 98 i Moačanin 1984: 35 i Moačanin 2001: 153). Službeni je jezik tada postao njemački. Njemački je jezik bio jezik škole, a njime su pisani i brojni zakonici tadašnjega vremena.

U ovom se radu istražuje odnos hrvatskih riječi i riječi stranoga podrijetla, turcizama i germanizama, njihovo usvajanje i prilagodba te u kolikoj su mjeri utjecali na jezik pjesama. Cilj je analizirati i prikazati leksikološku problematiku međujezičnih dodira i leksičkog posuđivanja te analizirati turcizme i germanizme na fonološkoj, morfološkoj, semantičkoj i leksičkoj razini.

\subsection{Društveno-povijesni kontekst hrvatsko-osmansko-njemačkih dodira}

Razlog analize isključivo posuđenica turskoga i njemačkoga jezika nalazi se u njihovoj čestotnosti pojavljivanja. Otuda se i nameće logično pitanje zašto su baš te posuđenice najdominantnije.

Odgovore dakako treba pronaći u povijesnim dodirima analiziranih jezika u kontaktu o kojem će biti više riječi u sljedećim poglavljima.

\footnotetext{
${ }^{181}$ Za razliku od gradova kontinentalne Hrvatske u kojima se najčešće koristio austrijski njemački područje Slavonije, Baranje i Srijema bilo je pod utjecajima dijalekata i sociolekata doseljenika iz različitih dijelova njemačkoga govornog područja. Dragičevič (2005: 87) tvrdi da na neujednačenost tadašnjeg „,njemačkog“ u Hrvatskoj ukazuju i germanizmi Slavonije s fonološkim elementima dijalekata, tj. mješavine rajnskofranačkog i bavarskog koji se nalaze u govoru dunavskih Švaba (Donauschwaben), naseljenih u doba vladavine Marije Terezije i Josipa II. O navedenom više u Sočanac (2005).

${ }^{182}$ Glibanović-Vajzović (1986: 141) definira da su „turcizmi sve riječi orijentalnoga i drugoga podrijetla primljene posredovanjem turskoga jezika, bez obzira na njihovu dublju etimologiju. Za riječi podrijetlom iz grčkoga i latinskoga jezika ponekad se ne može sa sigurnošću tvrditi da su k nama dospjele upravo posredovanjem turskoga. Riječima koje su podrijetlom iz arapskoga i perzijskog jezika, a kojima turski jezik obiluje, teško su mogle dospjeti drugim putem do nas.“

Uz termin turcizam, koji je u jezikoslovnoj literaturi najčešći, jezikoslovac Pranjković (2002) spominje i orijentalizme, riječi orijentalnoga podrijetla poput turskih (osmanskih), arapskih i perzijskih riječi.
} 


\subsubsection{Povijest hrvatsko-osmanskih dodira}

Početke dodira između hrvatskoga i osmanskog turskog jezika uočavamo još u 14. stoljeću kada Bitkom na Marici 1371. započinje osmansko gospodstvo nad Južnim Slavenima. Pobjedom nad velikom kršćanskom vojskom kod Nikopolja 1396. Osmanlije se prvi put pojavljuju u Slavoniji, dakle na hrvatskom teritoriju, a tim su činom i utvrdili osmansku vlast na Balkanskom poluotoku za nekoliko daljih stoljeća.

Turci Osmanlije vodili su kroz povijest intenzivnu osvajačku politiku. Pokoreni su hrvatski narod do početka 17. stoljeća, osim jedinoga Srijema, skupili u jednu administrativnu cjelinu, u beglerbegat (pašaluk ili ejalet) Bosnu koji se sastojao od sandžaka (vojnih okružja), a jedan od njih bio je i Požeški koji je obuhvaćao gradove Požegu, Viroviticu, Osijek, Vukovar, Đakovo i Brod. Srijem je potpadao pod Budim. U Srijemu je bilo glavno mjesto Ilok, u kojem je redovito sjedio sandžak-beg (paša), a samo ga iznimno nalazimo u Mitrovici (Šišić 2004: 327). Mažuran (1998: 78) tumači kako je područje Slavonije, kao najveći okupirani prostor pod osmanskom vlašću bilo više od stoljeća i pol (1526. - 1688.).

Dolazak Osmanlija nije se mogao spriječiti. U tim se protuosmanskim borbama posebno isticao erdeljski vojvoda i veliki vojskovođa Ivan (János) Hunyadi ${ }^{183}$ koji je zahvaljujući svojim uspjesima, koji su odjeknuli čitavom Europom, stvarao osjećaj u ljudi kako je stiglo pravo vrijeme da se Osmanlije udalje iz Europe. Svojim je vojnama u konačnici 1443. i natjerao sultana na desetogodišnje primirje. Navedene vojne operacije nisu spriječile kralja Vladislava Jagelovića da sljedeće godine dođe na osmanski teritorij i 1444. kod Varne, na bugarskoj crnomorskoj obali i bude katastrofalno poražen. Ta je ekspedicija bila i posljednji pokušaj hrvatsko-ugarskih, potom i habsburških vladara da pokrenu ofenzivu većih razmjera protiv Osmanlija (Goldstein 2003: 148).

Kako su Osmanlije sve više prodirale preko Bosne i na hrvatski teritorij, kralj Matijaš Korvin ${ }^{184}$ odlučio je organizirati protuakciju pa je 1463. i uspio zauzeti veliki dio okupirane Bosne i osnovati dvije banovine ${ }^{185}$. Jajačka je banovina trebala Osmanlijama zapriječiti prolaz u Hrvatsku, a Srebrenička u Slavoniju i južnu Ugarsku. Iako je svojim stavovima i vladanjem

\footnotetext{
${ }^{183} \mathrm{U}$ narodnim pjesmama poznat kao Sibinjanin Janko.

${ }^{184}$ Matijaš Korvin (1440. - 1490.) želio je suzbiti samovlašće velikaša, centralizirati državu te vladati uz potporu srednjeg i nižeg plemstva, klera i građanstva. Sukladno općem duhu svojih reformi i ambicija da stvori vojsku koju može neposredno kontrolirati, sredinom sedamdesetih godina 15. stoljeća ustrojio je u Slavoniji posebnu plaćeničku vojsku pod zapovjedništvom vlastitog kapetana (Goldstein 2003: 149).

${ }^{185}$ Jajačka banovina prostirala se na području Vrbasa sa središtem u Jajcu (između riječnih tokova Sane, Vrbasa i Bosne), a Srebrenička između rijeka Bosne i Drine sa središtem u gradu Srebreniku.
} 
Matijaš Korvin ${ }^{186}$ smetao plemstvu koji su razloge njegova svrgavanja tražili u tobožnjem zanemarivanju protuosmanske obrane i favoriziranju stranaca na važnim državnim funkcijama, njegovoj samovolji, bahatosti i nepoštivanju plemićkih povlastica, nisu ga uspjeli svrgnuti s vlasti. Matijaša nasljeđuje Vladislav II. Jagelović za čijeg vremena nastupa novo doba feudalne anarhije.

Kroz stoljeća koja su uslijedila ratovi su se nastavljali, a ujedno i povremena primirja. Sve je to utjecalo na život podjarmljenoga stanovništva, no Goldstein (2003: 154) zaključuje iako su Osmanlije prouzročile rasap teritorija i seobe te dovele Hrvatsku u bijedu, njihova je vlast nad nekim dijelovima Hrvatske do kraja 17. stoljeća zapravo prilično dobro funkcionirala, a gospodarstvo i trgovina bili u europskim razmjerima prilično razvijeni.

Dakle, s dolaskom Osmanlija na naše područje nastupilo je razdoblje masovnoga iseljavanja starosjedilačkoga katoličkog stanovništva, redovnika i svjetovnoga svećenstva te naseljavanje muslimana i Vlaha ${ }^{187}$ pravoslavaca. No to nije teklo tako mirno. Osmanski prodori bili su poznati pod imenom akin, a sudionici takva pohoda kao akindžije: manja ili veća skupina osmanskih ratnika $\mathrm{u}$ rano bi se proljeće zaletjela iz dubine osmanskog teritorija $\mathrm{u}$ dubinu kršćanskoga te palila i pljačkala izbjegavajući izravan sukob s protivničkom vojskom; s dolaskom jeseni, bogato namirena plijenom, vraćala bi se kući. Nekoliko uzastopnih prodora takve vrste na neko područje za koju bi godinu otjeralo sve seljake, posve im uništivši egzistenciju. Takvi su prodori nakon pada Bosne 1463. godine postali sve češći i žešći. Suvremenik, kroničar pop Martinac, tvrdi da Osmanlije "nalegoše na jezik (narod) hrvatski, šaljući velike čete". Osmanske su čete preko Slavonije i Hrvatske stizale sve do Kranjske, Štajerske, Koruške, Gorice, Istre i Furlanije (Goldstein 2003: 151).

Osvajanjem Srebreničke banovine 1512. Osmanlijama je otvoren put s juga prema istočnim dijelovima Slavonije, padom Beograda 1521. prolaz prema sjeveru i zapadu te njihova vojska uspješno ulazi u Srijem i Slavoniju, a padom Jajačke banovine i Banja Luke 1527.

\footnotetext{
${ }^{186}$ O Matijašu Korvinu povjesničar Ferdo Šišić (2004: 242) govori da „bijaše nesumnjivo najznatniji vladar svoga vremena. Potpuno samostalan, energičan, nepopustljiv prema svojim protivnicima, gospodar svakom oligarhijskom pokretu, a seljaku i građaninu pravi zaštitnik - to su kreposti što su ga resile. Otuda drevna hrvatska rečenica: 'Pokle kralj Matijaš spi, nikakve pravice ni.'“

${ }^{187}$ Termin Vlah u pojedinim je hrvatskim zemljama i u različitim vremenima označivao različite društvene grupe: od 16. stoljeća Vlah je u Istri bio svaki došljak; sve do danas ta riječ u Dalmaciji označava stanovnika zaleđa (u odnosu na obalne gradove i otoke), neovisno o vjeri i podrijetlu, dočim je, često s pogrdnim prizvukom, u kontinentalnom dijelu Hrvatske označavala pravoslavca, Srbina (Goldstein, 2003: 134). Car Dušan ih u „Zakoniku“ jasno razlikuje od Srba, Arbanasa i Grka, a u Hrvatskoj se prvi put spominju u prvoj polovici XIV. st. (upravo 1322). Vlasi su se bavili ponajviše prenošenjem robe na konjima i mazgama (turma i turmari, u dubrovačkim spomenicima ,ponosnici“) i stočarstvom, provodeći nestalan život, ljeti na planinskim pasištima po katunima, a zimi bliže pristojnoj morskoj obali. Proizvodili su sir u pogačama, maslac i ovčju vunu. Stoga je ime Vlah od XIV do XVI st. u prvom redu značilo stočara, dakle obilježavalo je ponajprije zanimanje ili socijalni položaj, a ne tuđu narodnost (Šišić 2004: 251).
} 
konačno je i omogućen protok velikoga vlaškog vala, koji se preko srednjega i donjega toka rijeke Vrbasa usmjerio u sjeverne dijelove Bosanske krajine od kuda će preko donjega toka Une i preko Save poticati osmanske prodore prema Kostajnici i Sisku te u zapadnu Slavoniju prema Požegi i Virovitici. Tako je, relativno polako, ali postojano, otkidan dio po dio hrvatskoga teritorija.

Manjkavost snage, raspršenost ljudi, nedovoljna povezanost i slaba organiziranost te učestale međusobne svađe među plemstvom nisu bile dovoljne za obranu. Na taj su način propadala i plemićka zemljišta, a s njima i naselja, samostani i brojne crkve koje su Osmanlije uredno rušili do temelja ili bi ih pretvarali u džamije i staje dok bi od crkvenih zvona salijevali topove. Međutim, hrvatska obrana, iako povremeno uspješna, općenito više nikome nije mogla jamčiti sigurnost, pa je sve jači pritisak Osmanlija prisiljavao vlastelu ${ }^{188}$ i kmetove da se povlače u sigurnije krajeve, prema sigurnijim dijelovima Hrvatske i u susjedne zemlje ${ }^{189}$.

U slabo naseljenim dijelovima tada vrlo brzo nastupa period visokoga stupnja islamizacije, ponajviše neiseljenoga seoskog stanovništva, a i vlastele koja je u toj pojavi vidjela lakši život ${ }^{190}$ i povlaštenije položaje ${ }^{191}$ zbog oslobođenja rajinskih poreza ${ }^{192}$ i izvanrednih nameta $^{193}$. Tako islamizirani dio pučanstva nije nestao u etničkomu pogledu, ali su

\footnotetext{
${ }^{188}$ Zrinski napuštaju Zrin (na Zrinskoj gori) i odlaze na posjede u okolici Čakovca. Sa selidbom Zrinskih i Frankapana, dviju najsnažnijih feudalnih obitelji, mijenja se i identitet područja (Goldstein 2003: 174).

189 Najveće hrvatske naseobine u inozemstvu nastaju u Gradišću (Burgenland) u istočnoj Austriji i zapadnoj Mađarskoj. Hrvatska sela nastaju i u južnim dijelovima Mađarske, u Slovačkoj, Moravskoj, u Bačkoj i Banatu te u talijanskoj pokrajini u jadranskom zaleđu Molise.

${ }^{190}$ Kršćani (džauri, od arap . ćafir, heretik) bi, bez obzira na opravdanost, redovito gubili parnice protiv muslimana pred vrhovnim sucem, kadijom, a kazne su najčešće bile globe u kadijinu korist, dok bi se rjeđe prakticiralo sječenje ruku, jezika, nosa, ušiju i nabijanje na kolac.

${ }^{191}$ Svi su Osmanlije, oni od iskona ili oni koji bi prešli na islam, bili jednaki po vjeri, pred zakonom i po običajima. I najsiromašniji čovjek mogao je postati vezirom jer kod njih nije odlučivalo podrijetlo već sreća, sposobnost i spretnost pojedinca. Na taj bi način i poislamizirani svijet postao sastavni i ravnopravni dio timarsko-spahijskog sustava. U osvojenim zemljama tako bi se žiteljstvo dijelilo u dva razreda: u pravovjernike (muslimane) $\mathrm{i}$ nevjernike (raja, stado). Kršćani (nevjernici) nisu imali gotovo nikakvih prava već samo dužnosti, a od svojih muslimana gospodara morali su se razlikovati u svemu. Primjerice, ni njihova odjeća nije smjela biti ni po vrijednosti ni po boji ili dizajnu kao gospodareva, nisu smjeli jahati konje, već su njihova prijevozna sredstva bile mule i magarci, a budući da su bili nevjernici vjerovalo se kako nisu bili ni sposobni nositi oružje.

${ }^{192}$ Kršćanski podanici imali su obvezu plaćati desetinu spahiji od plodina i harač (džizju) sultanu za vojsku u gotovu novcu, i to od svakog ognjišta po dukat. Harač nije bio velik, ali je način na koji se skupljao izazivao strah u raji. Haračlije su u pratnji pisara prolazili kroz sela i s najvećom okrutnošću prikupljale harač. Roditeljima je od svih davanja najteži teret bio danak u djeci (devširme). Svakih pet godina ili po potrebi i češće najzdraviji bi se mladići, po sultanovoj naredbi, odvodili u Carigrad. Tamo bi se najprije poturčili, a potom obrazovali za vojnike ili druge carske službenike. Mlade bi se djevojke vodile u sultanski ili drugi gospodski harem. Samo su imućniji roditelji mogli otkupljivati svoju djecu od podmitljivih haračlija velikim svotama zlata dok sirotinja za to nije imala nikakvu priliku.

${ }^{193} \mathrm{O}$ različitim vrstama poreza i nameta poput plaćanja zemljarine ili kunovine (marturine), poreza „lucrum camerae“ (dobiti kovnice), izvanredne ratne daće (hrv. riz, lat. taxa, contributio, dica), „počasnoga dara“, tzv. zalaznine (descensus), jednog od najneugodnijih poreza, koji je podrazumijevao gošćenje kralja i njegova zamjenika, bana i hercega te njihovih činovnika za vrijeme odmora na putu više u Šišić (2004: 329-330).
} 
islamizacijom neminovno morale nastati promjene kojima se preferiraju orijentalnomuslimanske kulture i tradicija (Živković 1996: 176).

Dakle, s Osmanlijama u hrvatskim područjima, naročito na tlu Slavonije, Baranje i Srijema zaživjela je i orijentalna kultura čiji su elementi kroz stoljeća koja su slijedila postali sastavni elementi hrvatske kulture tih krajeva, naročito narodne, pučke baštine - folklora, običaja, narodne nošnje gdje se poseban utjecaj vidi u imenovanju brojnih odjevnih predmeta i predmeta svakodnevne upotrebe u kućanstvu.

\subsubsection{Povijest hrvatsko-njemačkih dodira}

Dodiri su između hrvatskoga i njemačkoga jezika započeli još u ranomu srednjem vijeku, u 7. i 9. stoljeću kada su uspješnim osvajačkim pohodima na naša područja stizali Franci te su ti dodiri trajali različitim intenzitetom do početka 20. stoljeća. Taj dugi period međusobnih dodira zbog različitih jezično-političko-kulturnih uvjeta ostavio je nesumnjivo veliki trag u hrvatskoj povijesti. Kako je njemačka civilizacija i kultura bila daleko naprednija tako je i njezin utjecaj posredstvom Nijemaca bio daleko jači. Stoga, ni ne čudi otkuda toliko mnogo germanizama u hrvatskome jeziku. Odnos njemačkoga spram hrvatskoga jezika bio je takav da je morao imati za posljedicu utjecaj njemačkoga jezika na hrvatski, a ne obratno (Babić 1990: 214).

Za vrijeme prvih izravnih hrvatsko-njemačkih dodira, u hrvatski jezik preko njemačkoga ulazi manji broj uglavnom latinskih i grčkih riječi vezanih uz kršćansku terminologiju, i nekolicina uglavnom izvornih njemačkih riječi vezanih za kućanstvo (Stojić 2006: 54). Slijedom povijesnih okolnosti u kasnom srednjem vijeku u hrvatski jezik primljen je dio njemačkih riječi posredstvom mađarskoga jezika s obzirom na to da je Hrvatska bila povezana s Ugarskom personalnom unijom (Talanga 1990: 130). Kao posljedica prvog kolonizacijskoga pokreta njemačkih govornika u hrvatske krajeve, u hrvatskom jeziku ustanovljen je određeni broj njemačkih riječi. U želji da unaprijedi državu, ugarski kralj Stjepan Sveti (998. - 1035.) svojim je zakonskim dekretima pozivao strane zanatlije lutalice da kao gosti (hospites) dođu u njegovu zemlju i tu se nastane i ostanu živjeti i raditi (Geiger, Kučera 1995: 85).

Najintenzivnije se posuđivanje germanizama javlja u periodu od 16. do 20. stoljeća ${ }^{194}$. Cvjetanjem trgovačkih zanimanja u naše krajeve stižu prvo obrtnici i trgovci, kasnije liječnici,

\footnotetext{
194 Vrijeme Habsburške Monarhije i Austro-Ugarske Monarhije (1527. - 1918.). To je vrijeme kada uslijed
} mohačkog poraza 1527. ugarsko-hrvatski kralj Ludovik II. gubi život u nabujalom potoku bježeći od neprijatelja. 
ljekarnici i službenici s područja današnje Austrije i južnonjemačkih zemalja, koji žive i djeluju unutar različitih slojeva gradskih i seoskih zajednica (Dragičević 2005: 86). Sve to više pojačava izravni dodir domaćega stanovništva s doseljenicima, stranoga jezika s hrvatskim jezikom. Kako dolazi do sve većeg miješanja stanovništva i pojačanih kulturnih utjecaja, pojavljuju se posuđenice zastupljene u sve većem broju leksičko-semantičkih područja i polja. Posuđenice prodiru u sva područja života i djelatnosti (obitelj, predmeti svakodnevne uporabe, običaji, higijena, poljoprivreda, obrt, trgovina, promet, tehnika, uprava...) o čemu svjedoči i pozamašan broj još uvijek živih germanizama za kojih nema ni danas pravovaljane zamjene.

U 18. stoljeću na velikom području današnje Hrvatske njemački se uvodi kao službeni jezik vojske i sudstva, a na području Vojne krajine osnivaju se i carske škole u kojima dječaci uče njemački jezik i pismo. Tako je Vojna krajina ${ }^{195}$ (područje osnovano kao obrana od Osmanlija nakon njihova istjerivanja s naših teritorija) postala mjesto u kojem je jedan pritisak zamijenjen drugim. Naime, zanimljiv je podatak da unatoč tolikome prestižu, njemački jezik nikad nije postao jezikom naše književnosti. Jednako tako nikada nije postao ni jezikom crkve, a poslije raspada Austro-Ugarske Monarhije 1918. njemački je jezik gubio u Hrvatskoj svoj prestižni status. Završetkom Drugoga svjetskoga rata njemački je jezik anatemiziran jer se smatrao jezikom nacista i okupatora (Žepić 1996: 318).

Nakon izvjesne stagnacije poslije Drugoga svjetskog rata, izazvane političkom situacijom i iseljavanjem velikoga broja obitelji njemačkoga podrijetla, izravni se kontakti s njemačkim jezikom ponovno obnavljaju odlaskom hrvatskoga žiteljstva na rad u Njemačku. Pored jezičnoga miješanja koje se uglavnom odvija kod djece rođenih i odraslih u stranoj

Ugarsko-hrvatsko prijestolje tada ostaje prazno jer Ludovik II. nije imao nasljednika. Knez Krsto Frankapan još se početkom te iste godine zalagao da Hrvatska nađe sebi drugoga gospodara jer je čvrsto vjerovao da u HrvatskoUgarskom Kraljevstvu nema snage za pravi otpor prema Osmanlijama. Na sastanku u Križevcima naglašavao je kako bi pravi izbor za Hrvatsku bio austrijski nadvojvoda Ferdinand Habsburški budući da je pomagao Hrvatsku i novcem i vojskom više nego Ludovik II. te je taj prijedlog konačno i postao odlukom hrvatskoga plemstva, kao i manjine u Ugarskom saboru i Čeha na saboru u Cetingradu (sjeveroistočno od Slunja, na granici s Bosnom) 1527. Kralj Ferdinand tada se obvezao da će na granici Hrvatske i Kranjske držati dovoljno vojnika za obranu i da će opskrbljivati hrvatske utvrde. Iako se ugarsko plemstvo većim dijelom priklonilo novoizabranome kralju i osmanskome štićeniku Ivanu Zapolji, pozivajući se na saborski zaključak iz 1505. po kojem je svaki stranac isključen iz kandidature za prijestolje, Ferdinand je odlučnim borbama, obećanjima i darovnicama postupno uspio pridobiti najutjecajnije Zapoljine pristaše te zapoljevci više nisu predstavljali ozbiljnu prijetnju uspostavi habsburške vlasti u hrvatskim zemljama.

195 Vojna krajina zamišljena je i utvrđena kao posebna austrijska pokrajina u kojoj je pravo odlučivanja u potpunosti preuzela središnja vlast u Beču iako je i dalje na papiru bila hrvatski teritorij. Tako je ustrojena djelotvorna obrana od Osmanlija koja će umnogočemu pridonijeti njihovu zaustavljanju i konačnom prelasku Monarhije u ofenzivu potkraj 17. stoljeća. Vojna je krajina bila hrvatska brana, ali je to za sam krajiški teritorij značilo neprekidno ratno stanje - opću nesigurnost i rizičnost putovanja, nerazvijenu privredu. Neredovitost u isplatama krajiških plaća poticala je pljačku i stvarala stanje u kojem je odlazak po plijen s jedne na drugu stranu granice bio posve uobičajen i moralno prihvatljiv. Manjak hrane, vina i oružja dizao je cijene, što je dodatno opterećivalo ionako siromašno stanovništvo (Goldstein 2003: 189). 
zemlji, dolazi i do jezičnoga posuđivanja u nas, što je vidljivo u riječima kao gastarbajter, ofental, bauštela, robau i dr. (Stojić 2008: 359).

Za prilagodbu germanizama i turcizama u hrvatskom jeziku važni su različiti unutarjezični i izvanjezični razlozi. Prilagodba germanizama ovisila je o podrijetlu i statusu doseljenika koji su sa sobom na nova područja donosili svoje dijalekte i sociolekte. S druge pak strane presudnu je ulogu u procesu prihvaćanja leksika njemačkog jezika svakako odigrala i neujednačena socijalna pripadnost i obrazovna razina domaćega stanovništva u određenome vremenskom razdoblju. Posljedice su takve jezične situacije različite replike istoga modela (Dragičević 2005: 89).

Bitnu ulogu u prilagodbi turcizama u hrvatskome jeziku prvenstveno je odigrao veoma različit odnos među dvjema kulturama i narodnostima uočljiv kroz nasilan oblik ponašanja osvajača prema podjarmljenome stanovništvu koji je prelazio na islam radi lakšeg života i povlaštenijih položaja te tako $\mathrm{s}$ vremenom prihvatio dio nametnute kulture i jezičnih karakteristika. Drugi bi se aspekt odnosio na iseljavanje domaćega stanovništva i naseljavanje tih krajeva muslimanima vlaškim pravoslavnim stanovništvom koji nisu govorili jezikom izvornih govornika te su na novonaseljena područja uz svoje običaje donosili i jezičnu posebnost koja je prodirala s vremenom sve više u jezični inventar domicilnoga stanovništva i na taj ga način mijenjala i preoblikovala.

\subsection{Jezično posuđivanje}

Od kada postoje jezici, postoje i njihovi međusobni doticaji. Tijekom povijesti ljudi su često dolazili u kontakt jedni s drugima. Pri tome su kontaktu tijekom komunikacije govornici preuzimali pojedine riječi radi lakšega sporazumijevanja, trgovine ili općenito imenovanja nove stvari, pojma ili pojave te su ih na taj način unosili u svoj jezični sustav. Dakle, jezično je međudjelovanje nužnost i potreba i ono je često rezultat različitih povijesnih, političkih, gospodarskih i kulturnih dodira. Njegova je posljedica dvojezičnost ili višejezičnost. Dvojezičnost definiramo kao poznavanje i uporabu više od jednoga jezika u komunikacijskome procesu i ona je bitan preduvjet za uspostavljanje međujezičnih utjecaja ${ }^{196}$. Mjesto doticaja

196 Više o međujezičnim utjecajima, intimnom i kulturnom posuđivanju u Sočanac (2004). 
jednoga jezika s drugim uvijek je bila svijest dvojezičnoga govornika ${ }^{197}$ kao posrednika između najmanje dviju jezičnih zajednica, a k tome i dvaju jezičnih sustava. Ti jezični susreti nisu uvijek rezultirali posuđivanjem, tu je moglo doći posljedično i do stvaranja novih jezičnih sustava ili do izumiranja, odnosno nestajanja postojećih jezika.

Bilingvalni govornik, pored materinskoga jezika, može koristiti i riječi drugoga jezika. Njegov jezik tada nosi oznaku jezika primaoca, a jezik iz kojeg je preuzeo riječ naziva se jezikom davaocem.

Osim posuđenica koje su rezultat potrebe, mogu se preuzimati i riječi za koje postoje istovrijednice $u$ jeziku primaocu, a vezane su uz ugled jezika davaoca i društveni status koje posuđenice toga tipa imaju u određenoj zajednici (Sočanac 2004: 31). Sve dugotrajnijom i češćom uporabom nekih posuđenica mogućnost da se one dalje razvijaju kao i domaće riječi rezultat je toga da je u svijesti govornika pojam o njezinu stranome podrijetlu u potpunosti nestao i ona se više ne tretira kao strana. Također postoji mogućnost i da neke strane riječi nikada ne steknu status posuđenica jer se u jeziku primaocu pojave samo zbog trenutačne potrebe, mode ili pomodarstva i zatim vrlo brzo nestanu, a da pri tome nikada nisu ni ušle u širu uporabu i prošle potpuni proces prilagodbe posuđenica.

Pri prijenosu riječi iz jezika davaoca u jezik primalac posuđena riječ može zadržati neke elemente modela kojih nema u jeziku primaocu ili se model može zamijeniti nekom istovrijednicom jezika koji prima. Dakle, u prvom se slučaju govori o importaciji, a u drugom primjeru o supstituciji. U sustav jezika primaoca govornik tako može unijeti strani akcent, strani leksem, novi slobodni morfem ili češće konsonantsku skupinu koja se protivi distribuciji fonema u jeziku primaocu. Zbog toga se kaže da dolazi do inovacija u jeziku primaocu. Po Haugenu (1956: 52) ,,ako se u jezik primalac ne uvede nikakav novi slobodni morfem, nego se strana riječ ili izraz prevede, strani se materijal zamjenjuje domaćim, ali u skladu sa stranim modelom govori se o prevedenici ili kalku.“ Dakle, proces jezičnoga posuđivanja reguliraju te dvije osnovne jezične operacije: supstitucija i importacija.

Preuzeta se riječ prema Haugenu (1956: 56) može prilagoditi u sustavu jezika primaoca na tri načina, kao strana riječ ili model jezika davaoca kada bilingvalni govornik uvodi nove riječi u fonetskome obliku koji je tako blizak obliku izvora koliko može taj govornik izgovoriti. Drugi se način prilagodbe odnosi na tuđicu ili kompromisnu repliku. Kada bilingvalni govornik

\footnotetext{
${ }^{197}$ Prvi i osnovni zadatak bilingvalnog govornika, koji je pored materinskoga naučio još jedan jezik, je u tome da drži ta dva jezika odvojena. Čim on to ne može, nastupa lingvistička interferencija koju je Weinreich (1953) definirao kao devijacije od norme koje se javljaju u govoru bilingvnih govornika kao rezultat poznavanja više od jednog jezika. Termin interferencije uključuje i Filipović (1986: 36) ,'preuređenje' uzoraka jezika (language patterns) do čega dolazi stoga što su u fonološki sustav, morfologiju, sintaksu i leksik uneseni strani elementi.“
} 
dovoljno dugo ponavlja i koristi tu riječ ili ako je upotrebljavaju ostali govornici jezika primaoca uslijedit će djelomična supstitucija domaćim elementima. Ako pak tu riječ nauči monolingvalni govornik, doći će do potpune ili gotovo potpune supstitucije. U tom slučaju može se govoriti o trećem načinu prilagodbe, a to je posuđenica ili replika. Prije nego kompromisna replika dobije status replike i njezin oblik postane društveno prihvaćen, svaki ju govornik može oblikovati s više ili manje vjernosti prema modelu. Zbog toga ona može imati alternativne oblike dok konačno ne postigne svoj općeprihvaćeni oblik u jeziku primaocu. Kada u konačnici postigne svoj konačni oblik replika se tada ponaša kao svaka druga domaća riječ. Takve posuđenice hrvatska leksikološka literatura najčešće naziva usvojenicama, za razliku od tuđica koje nisu u dovoljnoj mjeri prilagođene novome jezičnom sustavu (usp. Samardžija 1998: 57).

U samom procesu posuđivanja ne može se tvrditi da je svaka strana upotrebljena riječ posuđenica. Da bi ona postala replikom, moraju je preuzeti i drugi govornici te ona treba prijeći $\mathrm{u}$ stalnu uporabu. To bi bio prijelaz iz uporabe u govoru (speech - parole) u stalnu uporabu u jeziku (language-langue) kako je objasnio Filipović (1986: 38).

Najveći postotak posuđenica u svakom slučaju čine imenice. Filipović (1986: 24) navodi da se većinom posuđuju cijele riječi, nikad derivacijski ili fleksijski sufiksi. Ali ponekad se strani sufiks, unesen u jezik s većim brojem posuđenica, počne upotrebljavati i u ostalim riječima i dodavati domaćim osnovama, tj. on postane proizvodan.

Proces jezičnoga posuđivanja započinje prijenosom modela iz jezika davaoca u jezik primalac. U tijeku posuđivanja, riječi iz jezika davaoca (model) u jezik primalac (replika), prolaze kroz određene promjene da bi se nakon nekoga vremena manje ili više prilagodile $u$ sustav jezika primaoca. Tada se kod govornika javlja jaka tendencija da elemente jednoga jezika izjednačuje s elementima drugoga. Weinreich (1953: 148) je uspostavu istovrijednica između jezika nazvao međujezičnom identifikacijom (interlingual identification).

Temeljnu inovaciju koju je Filipović uveo u svoju teoriju jezika u kontaktu podjela je na primarnu i sekundarnu prilagodbu do koje dolazi na većini jezičnih razina, a podrazumijeva kronološku i kvalitativnu komponentu. Primarna prilagodba (primary adaptation) kronološki prethodi sekundarnoj (secondary adaptation), a promjene do kojih dolazi u fazi sekundarne prilagodbe kvalitativno su različite od onih koje karakteriziraju primarnu prilagodbu (Filipović 1986: 55-57). Iz toga slijedi da se u etapi primarne prilagodbe posuđenica prilagođava sustavu jezika primaoca, dok se u etapi sekundarne prilagodbe dalje razvija u skladu s razvojnim tendencijama jezika primaoca. 


\subsubsection{Razlozi jezičnoga posuđivanja}

Hrvatska leksikološka literatura razloge posuđivanja stranih leksema obično dijeli na izvanjezične kao što su političke, gospodarske, kulturno-civilizacijske veze ili geografska blizina između dvije jezične zajednice te unutarjezične koji se odnose na prazna mjesta u sustavu koja se popunjavaju gotovim rješenjima iz drugih jezika (Samardžija 1998: 46-47). Međutim, praznine u leksičkom sustavu najčešće se odnose na riječi koje označavaju kulturne, religijske, gospodarske, povijesne i slične aspekte svojstvene drugoj jezičnoj zajednici, stoga se i u tom slučaju radi o društvenom kontekstu posuđivanja, a što navodi na zaključak da se unutarjezični i izvanjezični razlozi posuđivanja isprepliću i nisu strogo odvojivi.

Osim lingvističkih problema, koji su vezani uz interferenciju ${ }^{198}$, postoje i neligvistički problemi posuđivanja: sociološki i psihološki. Dakle, govornici često imaju potrebu uljepšavati svoj govor pomodnim izrazima drugoga jezika pa u tome pretjeruju ili ako žele imenovati novi predmet, pojam ili pojavu preuzetu od pripadnika druge jezične zajednice, zaboravljaju da stare riječi materinskoga jezičnog sustava mogu izraziti nove ideje.

Sve leksičke posuđenice dijele se na one za koje nema domaćih istovrijednica. Za takve posuđenice u literaturi nalazimo nazive kulturne ili nužne posuđenice. Drugi tip posuđenica one su za čije denotate već postoji domaća riječ. One se nazivaju luksuzne ili, u novije vrijeme, temeljne posuđenice (Myers-Scotton 2002: 41, Haspelmath 2009: 46). Pojava luksuznih posuđenica snažno je motivirana dominacijom gospodarski i kulturno razvijenije kulture pa onda i prestižem njezina jezika. Tu se može govoriti i o jezičnom snobizmu gdje je strani izraz često važniji od samoga sadržaja (Ljubičić 2011: 13).

Na temelju purističke literature Samardžija (1998: 63) utvrđuje pravila koja se tiču prihvaćanja i neprihvaćanja posuđenica. Posuđenice su jeziku potrebne ako za njih nema domaće zamjene ili je zamjena zastarjela. Postoji li domaća zamjena opsegom svoga sadržaja podudarna posuđenici, odnosno radi li se o sinonimima, prednost u uporabi ima domaća riječ. Ako je opseg sadržaja posuđenice širi ili uži od opsega sadržaja domaćega leksema, treba je rabiti onda kada je domaći leksem ne može zamijeniti.

Unutarjezični faktori koji utječu na posuđivanje riječ iz jezika davaoca mogu biti i niska čestotnost riječi koja dovodi do njihova nestanka i zamjene starom riječju, rješavanje homonimije te stalna potreba za istoznačnicama (Dabo-Denegri 2007: 41).

\footnotetext{
${ }^{198}$ Interferencija uključuje preuređenje uzoraka jezika do čega dolazi zbog toga što su u fonologiju, morfologiju, sintaksu i leksik jezika primaoca uneseni strani elementi jezika davaoca.
} 


\subsubsection{Posredno i neposredno posuđivanje}

Proces posuđivanja može se odvijati na dva načina. Posredno posuđivanje podrazumijeva kontakt dvaju ili više jezika preko jezika posrednika. Dakle, posredno se posuđivanje uspostavlja na posredniku preko kojeg jezik davalac dolazi u doticaj s jezikom primaocem. Filipović (1986: 50) tumači kako posrednik može biti neki jezik, ali su češće to masovni mediji koji su mnogo učinkovitiji posrednici od jednoga jezika. Ti posrednički mediji mogu biti pisana riječ (novine, tjednici, polumjesečnici i mjesečnici svih struka, itd.) ili govorena riječ (radio, televizija, film, kazalište, javna predavanja, razgovori, itd.).

O neposrednome posuđivanju govorimo kada je kontakt između govornika jezika davaoca i jezika primaoca izravan, odnosno direktan. Filipović (1986: 51) tvrdi da je jezik davalac u toj situaciji dominantan jezik, jezik prestiža, prvi jezik, jezik svakodnevnoga sporazumijevanja između doseljenika i starosjedilaca, jezik administracije, jezik na kojem se odvija cijela društvena djelatnost i veći dio života govornika jezika primaoca u sredini u kojoj žive, od školovanja do svakodnevnog zanimanja i ostalih aktivnosti.

Različiti tipovi posuđivanja daju i različite rezultate. Na rezultate utječe i mjesto, tj. zemlja u kojoj se kontakt ostvario. Dok posredno posuđivanje djeluje mnogo uže, tj. odnosi se samo na dijelove rečenice, uglavnom na riječi, neposredno se, okarakterizirano kao izravan kontakt dvaju jezika u aktivnoj komunikaciji, ostvaruje i u dijelovima rečenice, tj. riječima i u frazama, rečenicama i skupovima rečenica, diskursima. Takav je jezični kontakt puno intenzivniji i obuhvaća sustav jezika primaoca u njegovoj cjelini.

Iz toga slijedi da se posredno posuđivanje ograničava na one lingvističke razine na kojima je predmet istraživanja riječ. To znači da se analiza procesa posuđivanja i prilagodba posuđenica ograničavaju na fonološku, morfološku, semantičku i leksičku razinu. Neposredno posuđivanje obuhvaća i sve jezične jedinice veće od riječi te može obuhvatiti uz fonološku, morfološku, semantičku, leksičku razinu i sintaktičku i stilističku razinu jezičnoga sustava jezika primaoca.

\subsubsection{Primarna i sekundarna prilagodba posuđenica}

Posuđenica se prilagođava kroz integraciju u sustav jezika primaoca, tj. ona se već pri tom završnom stupnju prilagodbe može ponovno prilagođavati novim promjenama različitoga tipa karakterističnima za razinu na kojoj se javlja i u skladu sa sustavom jezika primaoca. Sve se te promjene u tijeku prilagodbe mogu podijeliti u dvije skupine. One koje se javljaju od 
trenutka prijenosa modela u jezik primalac sve do integracije replike u sustav jezika primaoca zovu se primarnim promjenama, a sekundarne promjene podrazumijevaju one promjene koje se javljaju na replici - posuđenici od integracije u sustav jezika primaoca nadalje. Prema toj pojmovnoj podjeli razlikuju se i dvije vrste prilagodbe: primarna prilagodba i sekundarna prilagodba.

To je novina koju je u teoriju jezika u kontaktu uveo Filipović (1986: 56) koji tvrdi da ta nova pojmovna podjela uključuje dva elementa: kronološki i kvalitativan i da ta dva elementa ne djeluju odvojeno, već su povezani. Njihova je najveća vrijednost u tome što se, polazeći od te pojmovne podjele, dobiva nova osnovna klasifikacija s pomoću koje se mogu preciznije odrediti i definirati promjene koje se u dotadašnjoj teoriji ${ }^{199}$ nisu razlikovale pa ni analizirale.

Kronološki element pokazuje da period primarne prilagodbe prethodi periodu sekundarne prilagodbe, a dužinu trajanja prve ili druge promjene vremenski je teško precizirati. Ključni je element upravo element kvantitete jer se prema njemu klasificiraju promjene iz procesa prilagodbe. Budući da su promjene koje se javljaju tijekom ta dva vremenska perioda posve različite, analizom se utvrđuju razlike u njihovoj kvaliteti. S obzirom na taj element $\mathrm{i}$ kronološki element dobiva se vrlo vrijedan kriterij za sveobuhvatnu klasifikaciju promjena.

U periodu primarne prilagodbe javljaju se brojne i nestalne inačice koje predstavljaju kompromisne replike. Razlog je tomu što kontakti dvaju jezika nisu ni stalni ni čvrsti pa se u tom periodu podjednako osjećaju utjecaji obaju jezika, jezika davaoca i jezika primaoca.

Sekundarne su promjene po kvaliteti potpuno drugačije, stalne su i nepromjenjive. To je period u kojem se posuđenica integrirala u sustav jezika primaoca i, kao takva, rijetko podliježe promjenama. Ako se takva promjena i dogodi, ona je uvijek u skladu s tendencijom razvoja jezika primaoca.

\subsection{Fonološka razina}

Pri međusobnom komuniciranju govornici u samom procesu jezičnoga posuđivanja pokazuju jaku tendenciju izjednačavanja elemenata jednoga jezika s elementima drugoga jezika jer se povode lingvističkim pravilom da foneme dvaju jezika identificiraju po njihovim fonetskim sličnostima, a one foneme kojih nema u jeziku identificiraju s onima koji su slični ili približno jednaki onima u materinskome jeziku.

\footnotetext{
${ }^{199}$ Dosadašnja podjela Haugen-Weinreichove teorije (na osnovi djelovanja supstitucije i importacije) poznaje tri stupnja prilagodbe i to model, kompromisnu repliku i repliku. Više u Filipović (1986).
} 
Na razini fonološkog sustava treba opisati inventar fonema jezika u kontaktu i njihov opis, distribuciju fonema (njihov položaj u riječi i sljedove u kojima se javljaju) te naglasak, njegov položaj i elemente koji ga određuju (intenzitet, kvaliteta, kvantiteta). Filipović (1986: 39) tvrdi da kako u fonološki sustav ulazi i opis razlikovnih obilježja kojima se međusobno razlikuju, komparacija dvaju sustava počinje usporedbom fonema na osnovi razlikovnih obilježja. Fonemi se mogu komparirati i na osnovi svojih genetskih opisa: a) prema otvoru; b) prema mjestu artikulacije; c) prema načinu artikulacije i d) prema ostalim fonetskim osobinama (zvučnost, aspiracija, itd.). Dakle, Filipović (1986: 40) nadalje tumači kako fonološka analiza mora uključiti: 1. fonetsku kvalitetu fonema obaju jezika, uključujući glavne alofone i komponente; 2. dopuštene sekvence fonema i alofona u oba jezika.

Kulturno-povijesni čimbenici hrvatsko-njemačko-turskih (osmanskoturskih) jezičnih dodira uvjetovali su činjenicu da je tijekom procesa posuđivanja iz njemačkoga i turskoga (osmanskoturskog) jezika prvotno osnova uglavnom bila (ra)govorni jezik, a tek u kasnijim slučajevima pisani jezik ${ }^{200}$. Stoga se prilagodba njemačkih i turskih (osmanskoturskih) fonema pretežito odvijala na temelju slušne percepcije (Stojić 2005: 192). Pretpostavka je stoga da se kod usvajanja germanizama i turcizama svaki fonem posuđenice nastojao tijekom komunikacijskih procesa zamijeniti fonemom hrvatskoga jezika koji je imao ista ili slična artikulacijska svojstva. Kod tih preuzimanja najčešće su upravo dijalekatski oblici odnosno stariji oblici posuđenica bili u uporabi.

Dakle, u prikazu njemačkog fonološkog sustava prikazat će se osnovne fonološke osobitosti južnonjemačke jezične varijante ${ }^{201}$ u odnosu na standardni njemački jezik i zatim usporediti s hrvatskim fonološkim sustavom. Prikazani fonološki sustav turskoga jezika

\footnotetext{
${ }^{200}$ Ova se konstatacija odnosi više na njemački jezik koji je u doba vladavine Marije Terezije i Josipa II. u 18. stoljeću uveden kao službeni jezik školstva, vojske i sudstva, a od druge polovice 18. stoljeća u Hrvatskoj se počinju objavljivati gramatike njemačkoga jezika i udžbenici hrvatskoga na njemačkome jeziku za izvorne govornike njemačkoga jezika kako bi se prilagodili svojoj životnoj sredini. Njemački je jezik postupno zaživio i u hrvatskim kazalištima jer su njemačke glumačke družine izvodile predstave na njemačkome jeziku, najprije za gospodstvo, a kasnije i za širu publiku. Njemački jezik krajem 18. stoljeća ima status jezika plemstva, imućnoga i obrazovanoga dijela stanovništva dok je stanovništvo Slavonije tada bilo jedva opismenjeno o čemu je tada pisao i na to upozoravao Matija A. Relković u svom djelu Satir iliti divji čovik.

201 Većina doseljenika doseljava s područja Štajerske, Graza i južnonjemačkih zemalja pa sa sobom nose i karakteristike tih dijalekata i sociolekata. Danas uobičajen, ponekad podrugljiv naziv „Švabe“ kao apelativ za sve etničke Nijemce, prvotno se odnosio samo na nekadašnje doseljenike iz pokrajine Švapske (Schwaben).
} 
fonološki je prikaz suvremenoga turskog ${ }^{202}$ koji se temelji na tzv. starom anadolijskome ${ }^{203}$ (maloazijskome jeziku).

\title{
3.3.1. Usporedba fonoloških sustava turskoga, njemačkoga i hrvatskoga jezika
}

\author{
Da bi se mogla proučiti prilagodba posuđenica na fonološkoj razini, moram se poznavati
}

fonološki sustav jezika koji su u kontaktu ne bi li se utvrdile sličnosti i razlike među

${ }^{202}$ Suvremeni je turski jezik u svojoj evoluciji prolazio kroz nekoliko razdoblja: 1. stari anadolijski turski jezik
(13. - 15. stoljeće); 2. ranoturski (u glavnim se crtama formirao na prijelazu iz 15. u 16. stoljeće); 3. srednjoturski
(od 17. do sredine 19. stoljeća); 4. novoturski (od sredine 19. stoljeća do prelaska na latinično pismo 1928. godine);
5. suvremeni turski. Ranotursko i srednjotursko razdoblje u razvoju turskoga jezika podudara se s razdobljem
procvata, kulminacije i nezadrživog slabljenja Osmanskoga Carstva, a osobito je po udaljavanju književnog od
govornog jezika. U toj socijalnoj stratifikaciji i „,funkcionalnoj“ diferencijaciji turskoga (osmanskog) jezika
značajniju ulogu imaju i kulturni, gospodarski, vjerski politički i drugi ekstralingvistički činitelji. Tako se na jednoj
strani formirao elitni književni jezik (Osmanlıca „,osmanski jezik“, u znanosti poznat pod nazivom Fasih Türkçe
„elitni (visoki) turski“), prepoznatljiv u prvome redu po visokom postotku arapskih i perzijskih posuđenica i tuđica
(do 90\%), ali i po iznimno snažnim utjecajima tih jezika na njegovo gramatičko ustrojstvo. Usporedo s njim
egzistirala je i druga varijanta književnoga jezika (Orta Türkçe, jezik srednje obrazovanih slojeva), koja je bila
bliža govornome jeziku. Njihovim se antipodom može smatrati govorni jezik puka (zapravo konglomerat
dijalekata, tzv. Kaba Türkçe ,,priprosti turski jezik“ ili Çoban Türkçesi ,pastirski turski jezik“), kojemu je Orta
Türkçe, bio stran, a elitni idiom Fasih Türkçe posve nerazumljiv.

Razdoblje novoturskog (novoosmankog) koincidira s tanzimatskim reformama (1839. - 1878.) i mladoturskom revolucijom (1908.), a protječe u nastojanjima da se književni jezik što više približi govornome te da se izvrše stanovite reforme osmanskog (modificiranog arapskog) pisma. Tek nakon urušavanja Osmanskog Carstva i proglašavanja republike (1923.) stvoreni su uvjeti za korjenitu jezičnu reformu, koju Turci nazivaju Dil devrimi ,jezična revolucija“. Glavni joj je impuls dao sam Ataturk, a njezinim se najznačajnijim segmentom može smatrati prelazak na latinični alfabet 1928. godine. Isto tako, na Ataturkovu inicijativu utemeljeno je 1932. godine Tursko lingvističko društvo (danas Türk Dil Kurmu sa sjedištem u Ankari), koje je postalo znanstveno i organizacijsko središte jezičnih reformi. Njegova je prioritetna zadaća bila stvaranje „,̌istoga“ turskog jezika (tzv. Öztürkçe), koja se imala ostvariti eliminacijom arapskih i perzijskih riječi i frazeologizama. (Siciolongvistički je zanimljivo da u prim desetljećima jezične purifikacije takav odnos nije bio i spram riječi iz europskih jezika). Purifikacija je vršena (a i danas se vrši nesmanjenim intenzitetom) na sljedeće načine: 1. prikupljanjem riječi iz anadolijskih dijalekata i njihovim uvrštavanjem u propisani leksički fond); 2. oživljavanjem starog, iznimno bogatog turskog leksika; 3. tvorbom novih riječi ili neologizama (čini se da u toj skupini ima i ,izmišljenih“ riječi i, u najmanju ruku, „umjetni“ izvedenica); 4. preuzimanjem riječi iz drugih turkijskih jezika (Turci taj leksički fond smatraju zajedničkim).

$\mathrm{Na}$ treći način, nedvojbeno najproduktivniji, stvoreno je na tisuće neologizama koji su značenjski ekvivalenti arapskih i perzijskih i, posebice u posljednjem desetljeću, engleskih i francuskih posuđenica i tuđica. To je dovelo do dviju paradoksalnih situacija: osiromašenja leksičkoga fonda u domeni znanstvene terminologije te do nastanka dvojnog i paralelnog leksika: turskoga i arapsko-perzijskog (i danas, nakon više od šest desetljeća jezičnoga čistunstva, suvremeni turski jezik posjeduje veliki broj riječi iz tih jezika). No takva je jezična politika imala za posljedicu još jedan veliki rez u kulturnome kontinuitetu Turaka (prvi je učinjen prelaskom na latinicu): novije ankete potvrđuju da turski srednjoškolci s velikim poteškoćama mogu čitati novine stare svega tridesetak godina. Za osnovu standardnoga turskog jezika uzet je istambulski govor (katkada se naziva i „dijalektom“), koji se od srodnih mu anadolijskih dijalekata najviše razlikuje na fonološkoj, morfološkoj i leksičkoj razini. Više u Čaušević (1996).

203 Tim su jezikom napisani najstariji književni spomenici oguskih plemena (njihovi su potomci Turci, Azerbajdžanci, Turkmeni) koji su prodirući s istoka u 11. i 12. stoljeću postupno naseljavali Malu Aziju. Ta su plemena značajna jer se suvremeni turski jezik formirao na temelju njihova jezika. Oguska su plemena u razdoblju od 12. do kraja 13. stoljeća imala državu pod vodstvom seldžučke dinastije. Pod naletom Mongola kad se ta država raspala na dvanaest kneževina (beylik) krajem 13. i početkom 14. stoljeća na zapadnim se njezinim granicama osamostalilo pleme Kayı, koje je, nakon smrti svojega oca, poveo Osman (Osmanbeg), rodonačelnik osmanske dinastije i utemeljitelj Osmanskoga Carstva. Više u Čaušević (1996). 
pojedinačnim fonemima koji karakteriziraju proučavane jezike. Sljedeća tablica (Tablica 8) to najbolje slikovito pokazuje. U njoj je dan cjelokupni fonološki inventar turskoga, njemačkoga i hrvatskoga jezika.

Tablica 8. Fonološki sustav ${ }^{204}$ turskoga, hrvatskoga i njemačkoga jezika

\begin{tabular}{|c|c|c|}
\hline \multicolumn{3}{|c|}{ Fonološki inventar } \\
\hline Turski jezik & Hrvatski jezik & Njemački jezik \\
\hline \multicolumn{3}{|c|}{ Fonemski sustav } \\
\hline 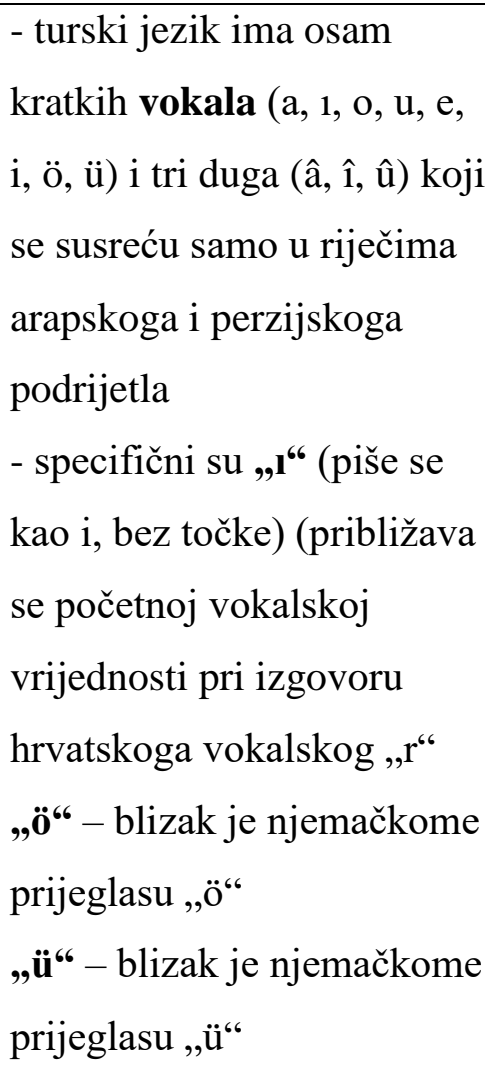 & $\begin{array}{l}\text { vokali u hrvatskome jeziku } \\
\mathrm{su} \text { : /i/, /e/, /a/, /o/, /u/ }\end{array}$ & $\begin{array}{l}\text { a) zaobljeni /U, o, ॰, y, Y, } \varnothing \text {, } \\
\text { œ/ i nezaobljeni /i,e/ vokali } \\
\text { kao proizvod oblika usnica -i } \\
\text { b) prednji i stražnji } \\
\text { realizirani odgovarajućim } \\
\text { položajem jezika } \\
\text { zaobljene /y:/,/Y/, /ø:/, /œ/, } \\
\text { neutralni vokal /ə/ i } \\
\text { vokalizirani neslogotvorni } \\
\text { fon /e/205 hrvatski glasovni } \\
\text { sustav ne poznaje }\end{array}$ \\
\hline
\end{tabular}

204 Jelaska (2004) smatra da je, u kognitivnom teorijskom okviru, s pomoću pojmova prototipno i rubno moguće objasniti teškoće u određivanju vrijednosti pojedinih glasova, odnosno prisutnosti i odsutnosti njihovih obilježja, je li neki glas u određenom jeziku uopće fonem ili nije, zašto se stručnjaci ne slažu oko kategorijalne pripadnosti pojedinih glasova, broja fonema u nekom jeziku (u hrvatskom je to slučaj zbog nejasnog statusa slogotvornog $r \mathrm{i}$ dvoglasa ie) te zašto se, primjerice, fonološka obilježja jednog jezika dijelom mogu tumačiti kao općejezična (i prototipna), a dijelom kao posebna (i rubna). Budući da su gotovo obavezni dio fonemskog repertoara u svim jezicima svijeta, neki su glasovi općejezično prototipni fonemi $(a, e, u, p, k, s)$. Glasovi koji se javljaju rjeđe, ili samo u pojedinim jezicima, pripadaju rubnom području (u hrvatskom su to diftonzi i zvučne palatalne afrikate). 205 Meinhold, Stock tumače (1980: 110) da vokalizirano neslogotovorno [e] predstavlja jednu od izgovornih varijanata fonema /r/. Vjerojatno je pod utjecajem ortografije u hrvatskim replikama prilagodbom prešao u /er/. Vokalizirani neslogotovorni fon /e/ nije vokalizirani neslogotovorni fon $\check{s} v a$, tj. $a$ koji se danas u hrvatskome jeziku umeće u konsonantne skupine (pr. moment i momenat). 


\begin{tabular}{|c|c|c|}
\hline 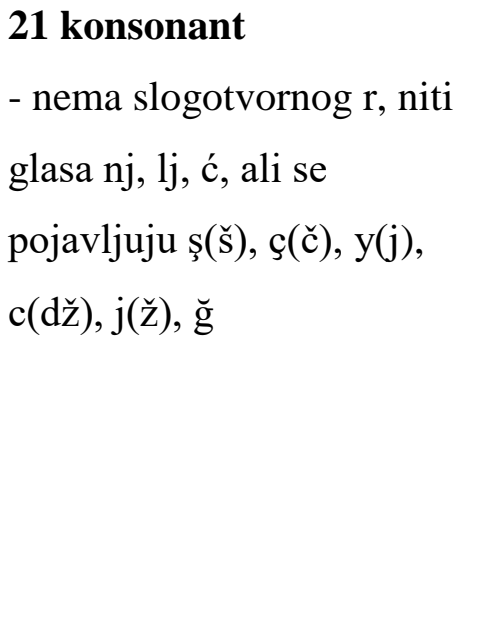 & 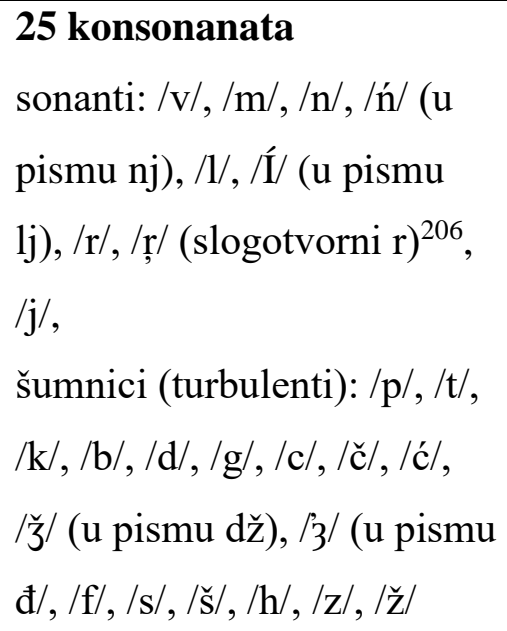 & $\begin{array}{l}20 \text { konsonata } \\
\text { ima alofone fonema /h/, a to } \\
\text { su: /x/, /ç/, laringal /h/, } \\
\text { uvular /R/ }\end{array}$ \\
\hline $\begin{array}{l}\text { šest je vrsta kombinatornih } \\
\text { dvoglasa: /ai/, /ei/, /1i/, /ui/, } \\
\text { /üi/, /ii// }\end{array}$ & $\begin{array}{l}\text { dvoglas } \\
\text { /ie/ }\end{array}$ & $\begin{array}{l}\text { dvoglasi } \\
\text { /ai/, /au/, /oy/ }\end{array}$ \\
\hline
\end{tabular}

Dakle, u turskoj pa i hrvatskoj latinici, u usporedbi s njemačkom, postoje neke razlike kao što je iz tablice vidljivo. U hrvatskome i turskome jeziku vlada načelo u kojem svaki fonem ima svoj grafem, u njemačkom, s druge strane, ne postoje točno, utvrđena, jednostavna pravila. Tako u turskome jeziku postoji grafem ş za [S], u hrvatskome $\check{s}$ za [̌̌], a u njemačkom se za isti fonem koristi kombinacija triju grafema sch. U njemačkome jeziku, što nije slučaj ni u hrvatskome ni u turskome jeziku, postoji i jedan tetragraf $t s c h$ [t $\left.\int\right]$ kao oznaka za jedan fonem koji se u hrvatskome bilježi kao /č/, a u turskome kao /ç/.

Latinski alfabet pokušava za svaki znak odrediti jedan grafem. Kao i kod drugih jezika, latinica je i u turskome i u njemačkome i u hrvatskome jeziku prilagođena, tj. djelomično je promijenjena i nadopunjena. Zato u tim alfabetima postoje neke zajedničke točke, ali i razlike. Turski alfabet ima 29 grafema (A a / B b / C c / Ç ç / D d / E e / F f / G g / Ğ ğ / H h / I 1 / I i / $\mathrm{J} \mathrm{j} / \mathrm{Kk} / \mathrm{L} \mathrm{l} / \mathrm{M} \mathrm{m} / \mathrm{N} \mathrm{n} / \mathrm{O}$ o / Ö ö/P p / R r / S s / Ş ş / T t / U u / ̈̈ ü / V v / Y y / Z z). Njemački alfabet ima 26 (odnosno 30 ako se uključe ä, ö, ü, B) (A a / B b / C c / Dd / E e / F f / $\mathrm{Gg} / \mathrm{H} \mathrm{h} / \mathrm{I} \mathrm{i} / \mathrm{Jj} / \mathrm{Kk} / \mathrm{Ll} / \mathrm{M} \mathrm{m} / \mathrm{N} \mathrm{n} / \mathrm{O}$ o / P p / Q q / R r / S s T t / U u /V v / Ww / X X / Y y / Z z). Hrvatski alfabet ima 30 grafema (A a/ B b / C c / Č č/ Ć ć/ D d / /DŽ dž/ Đ đ/ E e /

\footnotetext{
${ }^{206}$ Jelaska smatra da takozvano slogotvorno $r$ ne treba tretirati kao poseban fonem. To tim više što i drugi zatvomici mogu biti slogotvorni ( $l, I j, n$ i $s)$. Više o navedenom u Jelaska (2004: 185).
} 
F f / G g / H h / I i / j / K k / L l / LJ lj/ M m / N n / Nj nj/ O o / P p / R r / S s /Š š T t / U u / $\mathrm{V}$ v / Z z/ Ž ž).

U njemačkome alfabetu naime ne postoje grafemi Ç ç / Ğ ğ / 1 I / Ş ş / Č ć / Ć ć / DŽ dž / Đ đ / LJ lj / NJ nj, u turskome pak ne postoje Ä ä / Q q / ß / W w / X x / Č ć / Ć ć / DŽ dž / Đ

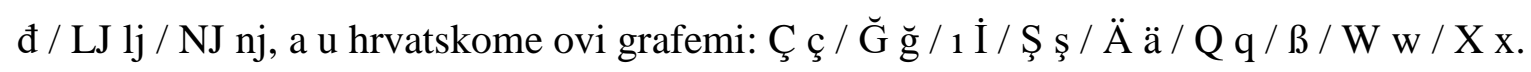

Kako bi se što bolje uočila glasovna vrijednost grafema, razlika i njegov izgovor $\mathrm{s}$ obzirom na grafemski sustav hrvatskoga jezika, donosi se tablični prikaz turske ortografije (Iş̧1ker 2010: 3) koja se zasniva na fonološkom principu jedan fonem - jedan grafem te je najbliža srpskoj ćirilici (Tablica 9).

Tablica 9. Prikaz turske abecede

\begin{tabular}{|c|c|c|}
\hline Slovo & Naziv slova & Glasovna vrijednost \\
\hline A a & $\mathrm{a}$ & $\mathrm{a}$ \\
\hline $\mathrm{B} \mathrm{b}$ & be & $\mathrm{b}$ \\
\hline $\mathrm{Cc}$ & ce & $\mathrm{dž}$ \\
\hline Ç ç & çe & $\check{\mathrm{c}}$ \\
\hline $\mathrm{Dd}$ & de & $\mathrm{d}$ \\
\hline $\mathrm{E} \mathrm{e}$ & $\mathrm{e}$ & $\mathrm{e}$ \\
\hline F f & $\mathrm{fe}$ & f \\
\hline Gg & ge & $\mathrm{g}$ \\
\hline$\breve{G} \breve{g}$ & ge & meko g (-) \\
\hline $\mathrm{Hh}$ & he & $\mathrm{h}$ \\
\hline $\mathrm{I}_{1}$ & 1 & $1(-)$ \\
\hline$\dot{\mathrm{I}} \mathrm{i}$ & $\mathrm{i}$ & $\mathrm{i}$ \\
\hline $\mathrm{J} \mathrm{j}$ & je & $\check{z}$ \\
\hline K k & ke & $\mathrm{k}$ \\
\hline L 1 & le & 1 \\
\hline $\mathrm{M} \mathrm{m}$ & me & $\mathrm{m}$ \\
\hline $\mathrm{N} \mathrm{n}$ & ne & $\mathrm{n}$ \\
\hline $\mathrm{O}$ o & o & $\mathrm{O}$ \\
\hline Ö ö & $\ddot{0}$ & $\ddot{O}(-)$ \\
\hline $\mathrm{Pp}$ & pe & $\mathrm{p}$ \\
\hline $\mathrm{R} \mathrm{r}$ & re & $\mathrm{r}$ \\
\hline
\end{tabular}




\begin{tabular}{|c|c|c|}
\hline S s & se & s \\
\hline Ş ş & şe & s \\
\hline T t & te & t \\
\hline U u & u & $\ddot{u}(-)$ \\
\hline$\ddot{U} \ddot{u}$ & $\ddot{u}$ & v \\
\hline $\mathrm{V} \mathrm{v}$ & ve & j \\
\hline $\mathrm{Y} \mathrm{y}$ & ye & $\mathrm{z}$ \\
\hline $\mathrm{Z} \mathrm{z}$ & ze & \\
\hline
\end{tabular}

Njemački pravopis nije fonetski, tj. za njega ne vrijedi pravilo jedan fonem - jedan grafem. To znači da se ne čita sve onako kako se piše stoga je od velikoga značaja tablično prikazati i njemačku abecedu (Wolf 2006: 507) radi lakše usporedbe s hrvatskim grafemskim sustavom (Tablica 10).

Tablica 10. Prikaz njemačke abecede

\begin{tabular}{|c|c|c|}
\hline Slovo & $\begin{array}{c}\text { Naziv } \\
\text { slova }\end{array}$ & $\begin{array}{c}\text { Glasovna } \\
\text { vrijednost }\end{array}$ \\
\hline A a & $\mathrm{a}$ & $\mathrm{a}$ \\
\hline $\mathrm{B} \mathrm{b}$ & $\mathrm{be}$ & $\mathrm{b}$ \\
\hline $\mathrm{C} \mathrm{c}$ & $\mathrm{ce}$ & $\mathrm{dž}$ \\
\hline $\mathrm{D} \mathrm{d}$ & $\mathrm{de}$ & $\mathrm{d}$ \\
\hline E e & $\mathrm{e}$ & $\mathrm{e}$ \\
\hline $\mathrm{F} \mathrm{f}$ & ef & $\mathrm{f}$ \\
\hline $\mathrm{G} \mathrm{g}$ & $\mathrm{ge}$ & $\mathrm{g}$ \\
\hline $\mathrm{H} \mathrm{h}$ & ha & $\mathrm{h}$ \\
\hline I i & $\mathrm{i}$ & $\mathrm{i}$ \\
\hline $\mathrm{Jj}$ & jot & $\check{\mathrm{z}}$ \\
\hline $\mathrm{K} \mathrm{k}$ & $\mathrm{ka}$ & $\mathrm{k}$ \\
\hline $\mathrm{L} \mathrm{l}$ & el & $\mathrm{l}$ \\
\hline $\mathrm{M} \mathrm{m}$ & em & $\mathrm{m}$ \\
\hline $\mathrm{N} \mathrm{n}$ & en & $\mathrm{n}$ \\
\hline $\mathrm{O} \mathrm{o}$ & $\mathrm{o}$ & $\mathrm{o}$ \\
\hline
\end{tabular}

\begin{tabular}{|c|c|c|}
\hline $\mathrm{P} \mathrm{p}$ & $\mathrm{pe}$ & $\mathrm{p}$ \\
\hline $\mathrm{Q} \mathrm{q}$ & $\mathrm{ku}$ & $\mathrm{q}$ \\
\hline $\mathrm{R} \mathrm{r}$ & er & $\mathrm{r}$ \\
\hline $\mathrm{S} \mathrm{s}$ & es & $\mathrm{s}$ \\
\hline $\mathrm{S}$ & es-cet & $\mathrm{ss} / \mathrm{l}$ \\
\hline $\mathrm{T} \mathrm{t}$ & te & $\mathrm{t}$ \\
\hline $\mathrm{U} \mathrm{u}$ & $\mathrm{u}$ & $\mathrm{u}$ \\
\hline $\mathrm{V} \mathrm{v}$ & fau & $\mathrm{v}$ \\
\hline $\mathrm{W} \mathrm{w}$ & ve & $\mathrm{w}$ \\
\hline $\mathrm{X} \mathrm{x}$ & iks & $\mathrm{x}$ \\
\hline $\mathrm{Y} \mathrm{y}$ & ipsilon & $\mathrm{y}$ \\
\hline $\mathrm{Z} \mathrm{z}$ & cet & $\mathrm{z}$ \\
\hline
\end{tabular}


Osim tih znakova postoje i vokali s prijeglasom: ä, $\ddot{\mathbf{o}}$, $\mathbf{u}$ (preglašeno a, o, u) i konsonanti koji se označavaju grupom slova: ch (ce-ha) koje se izgovara kao hrvatsko [h] ${ }^{207}, \mathbf{s c h}[\mathrm{S}]$ (es-ce-

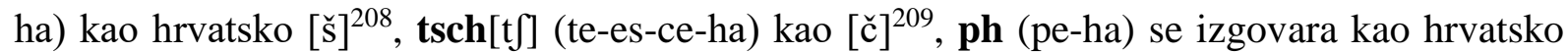
$[\mathrm{f}]^{210}$ i th (te-ha) kao hrvatski glas $[\mathrm{t}]^{211}$.

\subsubsection{Konsonanti $\mathrm{i}^{212}$}

Zbog postojanja mnoštva razlika u određenome broju glasova, konsonanti hrvatskoga, njemačkoga i turskoga glasovnog sustava iskazuju veće razlike. Najbolje je to uočiti u usporednome tabličnom prikazu koji nam omogućuje lakšu usporedbu fonoloških sustava analiziranih jezika.

Iz tablice (Tablica 11) jasno se nazire kako se konsonantni sustav hrvatskoga jezika sastoji od 25 konsonanata, a fonološki sustav može se prikazati na sljedeći način (Turk 1992: $18)$ :

Tablica 11. Prikaz konsonantskoga sustava hrvatskoga jezika

\begin{tabular}{|c|c|c|c|c|c|c|c|c|}
\hline \multicolumn{2}{|c|}{ način tvorbe } & & bilabijali & labiodentali & dentali & Alveolari & palatali & velari \\
\hline okluziv & zvučni & \multirow{6}{*}{ 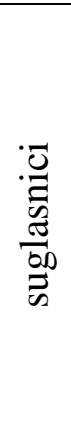 } & $b$ & & $d$ & & & $\mathrm{~g}$ \\
\hline & bezvučni & & $\mathrm{p}$ & & $\mathrm{t}$ & & & $\mathrm{k}$ \\
\hline \multirow[t]{2}{*}{ afrikate } & zvučni & & & & & & $\mathrm{dž}, \mathrm{d}$ & \\
\hline & bezvučni & & & & $\mathrm{c}$ & & $\check{c}$, ć & \\
\hline \multirow[t]{3}{*}{ frikativi } & zvučni & & & & $\mathrm{Z}$ & & Ž & \\
\hline & bezvučni & & & $\mathrm{f}$ & $\mathrm{s}$ & & $\check{\mathrm{s}}$ & $\mathrm{h}$ \\
\hline & neutralni & \multirow{3}{*}{$\begin{array}{l}\bar{U} \\
\bar{\Xi} \\
\frac{\pi}{00}\end{array}$} & & $\mathrm{~V}$ & & & $\mathrm{j}$ & \\
\hline nazali & neutralni & & $\mathrm{m}$ & & $\mathrm{n}$ & & $\mathrm{nj}$ & \\
\hline vibranti & neutralni & & & & & $\mathrm{r}$ & & \\
\hline
\end{tabular}

\footnotetext{
${ }^{207}$ Kao u primjeru doch [dox] ipak.

${ }^{208}$ Kao u primjeru das Fisch [fif] riba.

${ }^{209}$ Kao u primjeru der Teshardasch [čardaf] čardaš.

${ }^{210}$ Kao u primjeru die Phantasie [fantaz'i:] mašta.

${ }^{211}$ Kao u primjeru das Theater [te'a:tər] kazalište.

212 O zornim ilustrativnim prikazima svakog glasnika izrađenog elektropalatografijom i crtanjem bokocrta ili poprečnih presjeka govornoga trakta pri izgovoru više u Horga, Liker (2016).
} 


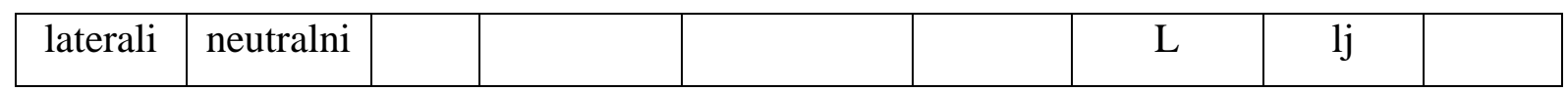

Konsonanti njemačkoga jezika kojih je 22 mogu se prikazati na sljedeći način (Žepić 1991: 29) (Tablica 12):

Tablica 12. Prikaz konsonantskoga sustava njemačkoga jezika

\begin{tabular}{|c|c|c|c|c|c|c|c|}
\hline \multicolumn{2}{|c|}{$\begin{array}{l}\text { mačin } \\
\text { artikulacije artikulacije }\end{array}$} & labijal & alveolar & postalveolar & palatal & velar & laringal \\
\hline okluziv & napeti & $\mathrm{p}$ & $\mathrm{t}$ & & & $\mathrm{k}$ & \\
\hline & nenapeti & $\mathrm{b}$ & $\mathrm{d}$ & & & $\mathrm{g}$ & \\
\hline nazal & & $\mathrm{m}$ & $\mathrm{n}$ & & & $\mathrm{x}$ & $\mathrm{h}$ \\
\hline frikativ & napeti & $\mathrm{f}$ & $\mathrm{s}$ & $\mathrm{f}$ & & $\mathrm{j}$ & \\
\hline & nenapeti & $\mathrm{v}$ & $\mathrm{z}$ & & $\mathrm{j}$ & & \\
\hline afrikata & & $\mathrm{pf}$ & $\mathrm{ts}$ & $\mathrm{t} \int$ & & $\mathrm{R}$ & \\
\hline vibrant & & & $\mathrm{r}$ & & & & \\
\hline lateral & & & $\mathrm{l}$ & & & & \\
\hline
\end{tabular}

Žepić (1991: 64-67) je ustanovio i opisao interferencije između hrvatskoga i njemačkoga standardnog jezika na fonološkoj razini. Tako navodi da je uočljivo kako hrvatski fonološki sustav ima više postalveolarnih i palatalnih konsonanata. Okluzivi i frikativi na prvi se pogled ne razlikuju, no relevantno obilježje za njemački jezik je napetost-nenapetost, a za hrvatski jezik zvučnost-bezvučnost. Stoga se u hrvatskome jeziku ti njemački glasovi izgovaraju nenapeto. Hrvatski fonološki sustav ne poznaje laringalne glasove. Stoga se aspirant u hrvatskome zamjenjuje frikativom [x]. Vibranti se različito artikuliraju: u njemačkome je jeziku glas [R] stražnji, a u hrvatskom glas [r] je glas koji se proizvodi vrhom jezika. Njemačko se /1/ ne palatalizira, ali se u njemačkim posuđenicama često izgovara kao glas [lj].

Za govornike hrvatskoga jezika nepoznata je afrikata /pf/ te se u posuđenicama često realizira kao frikativ /f/213. Afrikate /ts/ i t $\mathrm{f} /$ slične su hrvatskim fonemima /c/ i /č/. Stoga, samo u slučaju /pf/ možemo govoriti o potpuno stranome fonemu odnosno fonemskoj skupini. Kako u njemačkome jeziku na kraju sloga i ispred bezvučnoga konsonanta dolazi do obezvučenja

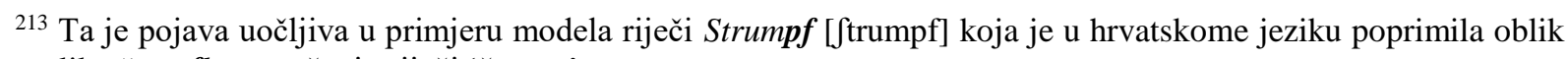
replike štrimfle u značenju riječi 'čarapa'. 
zvučnih konsonanata, a u hrvatskome je jeziku zvučnost moguća u toj poziciji, i kod takvih glasova dolazi do interferencije.

Turski jezik čini 21 konsonant. Oni se bilježe zasebnim grafemima i klasificiraju se prema kriterijima kao i u hrvatskome jeziku: po mjestu tvorbe ili artikulacijskome organu koji sudjeluje u tvorbi, načinu tvorbe, odnosno načinu svladavanja prepreke na koju nailazi zračna struja te položaju i jačini vibracije glasnica.

Konsonante se turskoga jezika može prikazati na sljedeći način (Čaušević 1996: 16) (Tablica 13):

Tablica 13. Prikaz konsonantskoga sustava turskoga jezika

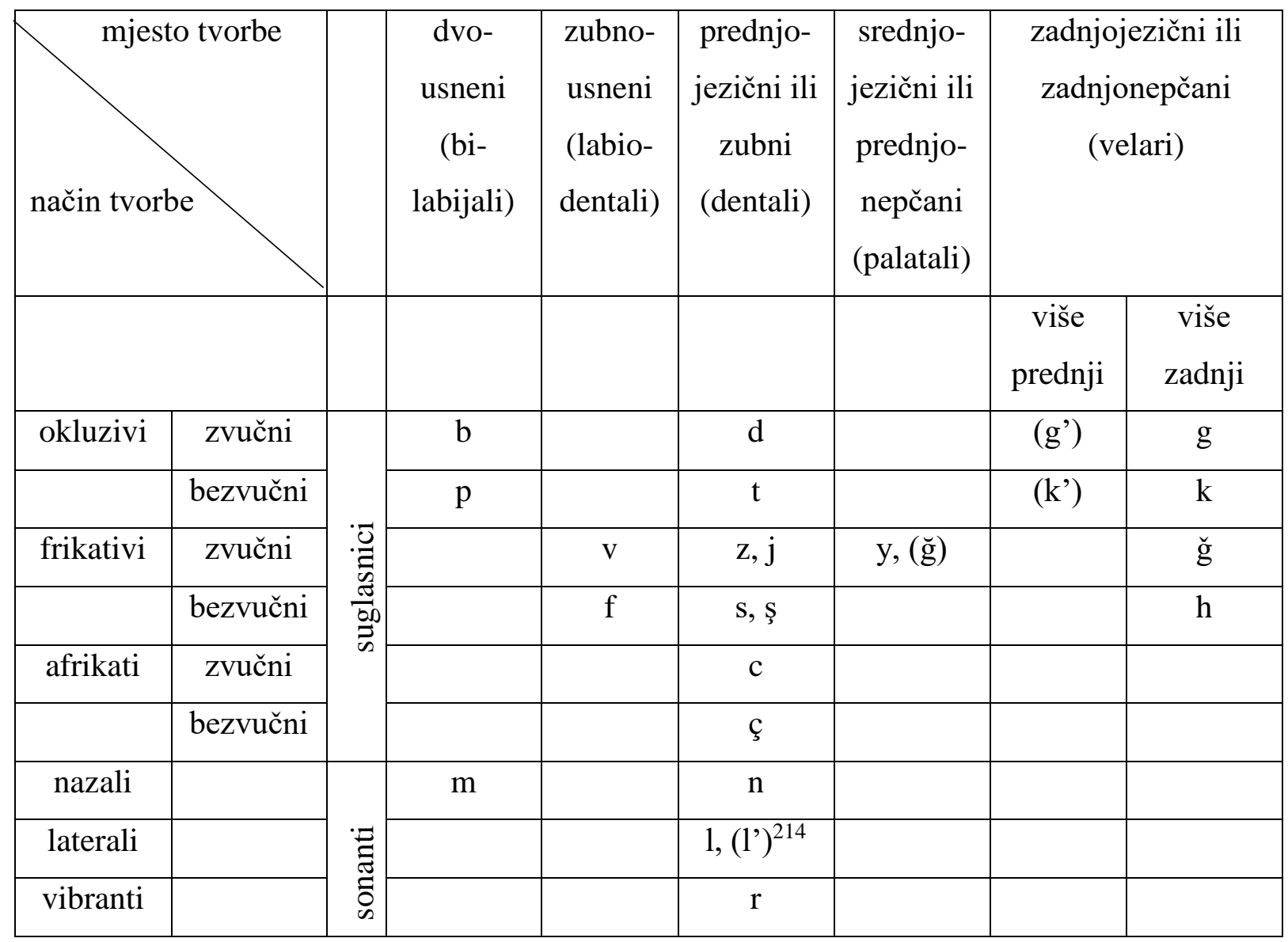

U turskome fonološkom sustavu nema toliko značajnijih razlika, ali bitno je napomenuti kako u njemu uopće ne postoje fonemi /nj/, /lj/, /ć/, ali se pojavljuju /ş/, /ç/, /y/, /c/ i /j/. Diferencijacija postoji i u podjeli samih glasova. Hrvatski fonem /v/ neutralni je frikativ, a u turskome jeziku on je zvučan. Dok hrvatski fonološki sustav obiluje palatalima, u turskome

${ }^{214}$ Čauševićeva napomena (1996: 16) glasi da su u zagradama dati alofoni /k'/,/g'/ i /l'/ koje neki turkolozi smatraju fonemima. 
jeziku samo je jedan palatal /y/ u značenju glasa [j]. Postoji razlika i u prednjojezičnim ili zubnim glasovima, tzv. dentalima gdje su u turskome fonološkom sustavu uz uobičajene hrvatske foneme /d/, /t/, /z/, /s/, /n/ uvedeni i /j/ u funkciji glasa [ž], /ş/ u funkciji glasa [š], /c/ kao glas [dž], /ç/ u funkciji glasa [č] koji su u hrvatskome jeziku označeni kao nepčanici ili palatali. Također su i hrvatski alveolari [r] i [1] u turskom fonološkom sustavu uvršteni u dentale.

Nadalje, i u izgovoru pojedinih glasova postoji razlika. Glasovi [c] i [ç] se izgovaraju

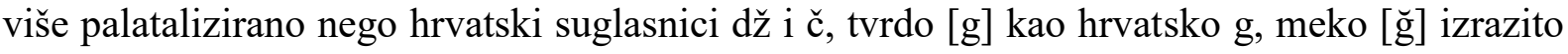
palatalizirano, tako da se u turcizmima prenosi kao hrvatski grafem đ, a glasovi [j] i [ş] više palatalizirano nego hrvatsko ž i š. Lateralni sonant [1], uz velarni zvučni okluziv [g] i njegov bezvučni parnjak [k], podliježe najvećem stupnju palatalizacije. Njegova tvrda varijanta izgovara se kao hrvatski glas [1]. Pri artikulaciji meke varijante vrh jezika leži na alveolama, a ne na gornjim zubima te se ona $u$ okruženju prednjih vokala izgovara znatno umekšano $u$ odnosu na hrvatski glas [1]. Stoga ni ne čudi da u velikom broju replika dolazi do interferencija. Konsonantske skupine, odnosno nizanje suglasnika unutar jednog sloga za razliku od hrvatskog i njemačkog jezika, u turskom je jeziku nepoznanica, pogotovo na početku riječi, što turski čini eufoničnim jezikom (Čaušević 1996: 35).

Kod turskog jezika govorimo o akcentu riječi i akcentu rečenice, prilikom čega se naglašava kraj riječi, odnosno rečenice. U njemačkom je pak akcent riječi na slogu osnove (korijenskom morfemu) i to najčešće na prvom. U hrvatskome jeziku postoje točno određena pravila akcentuacije ${ }^{215}$ po kojoj na zadnjem slogu nikako ne može stajati naglasak (Barić 2005: 69).

\subsubsection{Dvoglasi}

Dvoglasi njemačkoga jezika nemaju poseban fonološki status jer u opoziciju s drugim fonemima ne ulaze kao cjelina, već u opoziciju ulaze njihovi pojedini dijelovi (Žepić 1991: 29). Standardni njemački jezik razlikuje tri dvoglasa: ei, ai [ại], eu, äu [Dِi], au [aụ]. U njemačkom jeziku neka slova alfabeta čine nedjeljive kombinacije, označujući dvoglase ili se pak pojavljuje gomilanje konsonanata, kao na primjer <au> u Haus, <ei, ay> u Meier, Mayer, <eu> u heute te

\footnotetext{
${ }^{215} \mathrm{O}$ kritiziranju tradicionalnoga nazivlja i grafičkih oznaka za hrvatske naglaske, tipologiji naglasnih sustava i mjestu hrvatskoga naglasnog sustava u njoj, određenju hrvatskoga kao jezika s visinskim naglaskom, s ne posve slobodnom raspodjelom naglasaka te sa slogovnim, a ne udarnim ritmom više u Jelaska (2004).
} 
<tsch> u Deutsch, <qu> u Quelle. U turskome jeziku i hrvatskome takve kombinacije kao grafemi ne postoje (Nosetić 2013: 31).

Budući da je kontaktna pozicija dvaju vokala u turskome jeziku isključena, u turskim se riječima etimološki dvoglas ne susreće. Jedino kombinacijom slogovnoga i neslogovnoga glasa možemo stvoriti dvoglas, a tad se on naziva kombinatorni dvoglas koji se po Čauševiću (1996: 44) javlja u slučajevima kad se na osnovu koja se završava vokalom dodaju derivati pomoćnoga ili suponentnoga glagola imek: idi, imiş „bio je“, ise „ako je“, iken „bivajući“ te postpozicija ile. Do stvaranja dvoglasa dolazi zbog toga što ti oblici nikada ne privlače akcent, te otvoreniji vokal osnove riječi preuzima vokalsku, a zatvoreniji inicijalni vokal,$i “$ spomenutih derivata funkciju poluvokala. Stoga i dolazi do reduciranja glasa [i] i njegove promjene u polukonsonantski glajd ,y“. Postoji šest vrsta kombinatornih dvoglasa ovoga tipa: /ai/, /ei/, /1i/, /ui/, /üi/ i /ii/.

U hrvatskome jeziku, izuzev dvoglasnika ije, dvoglasi ne postoje, što znači da se dvoglasi stranih posuđenica moraju prilagoditi hrvatskome sustavu. 


\subsubsection{Vokali}

Hrvatski se vokali mogu prikazati na sljedeći način (Težak, Babić 1994) (Tablica 14):

Tablica 14. Prikaz vokala u hrvatskome jeziku

\begin{tabular}{|l|c|c|c|}
\hline visok & $\mathrm{i}$ & & $\mathrm{u}$ \\
\hline srednji & $\mathrm{e}$ & & $\mathrm{o}$ \\
\hline nizak & & $\mathrm{a}$ & \\
\hline & prednji & središnji & stražnji \\
\hline
\end{tabular}

Barić i suradnici (2005: 50) vokale dijele na isti način samo što u tablicu unose i dvoglas iẹ (Tablica 15):

Tablica 15. Prikaz vokala u hrvatskome jeziku

\begin{tabular}{|l|c|c|c|}
\hline visoki & i & & $\mathrm{u}$ \\
\hline & ie & & \\
\hline srednji & $\mathrm{e}$ & & $\mathrm{o}$ \\
\hline niski & & $\mathrm{a}$ & \\
\hline & prednji & srednji & stražnji \\
\hline
\end{tabular}

Po mjestu tvorbe vokali se dijele prema vodoravnom položaju jezika u odnosu prema tvrdom nepcu na prednje (palatalne), središnje i stražnje (nepalatalne). Prema stupnju uzdignutosti jezika prema nepcu na visoke, srednje i niske, a prema sudjelovanju i položaju usana razlikuju se vokali $e, i$, pri čijem su izgovoru usne u neutralnom položaju, samoglasnik $a$ sa širokim otvorom usana i samoglasnici $o, u$ s malo ispupčenim usnama i s njihovim okruglim, uskim otvorom. Prednji je i složeni vokal, dvoglasnik iẹ. Pri njegovu izgovoru govorni su organi najprije u položaju sličnom kao pri izgovoru glasa $i$, a onda postupno prelaze u položaj za izgovor glasa $e$. U hrvatskome književnom jeziku dvoglasnik ię ravan je dvoglas. Po mjestu tvorbe vokal r, je nenepčani, nadzubni (alveolarni) glas kao i konsonant $r$ (Barić i sur. 2005: 49). 
Navedena podjela prema visini u hrvatskom jeziku uvelike odgovara stupnju otvorenosti. Visoki su samoglasnici najzatvoreniji, srednji su samoglasnici otvoreniji dok je niski samoglasnik najotvoreniji.

Uspoređeno s hrvatskim vokalima prema Žepiću (1991: 49) sustav njemačkih vokala može se prikazati kao trostupanjski sustav (Tablica 16):

Tablica 16. Prikaz vokala u njemačkome jeziku

\begin{tabular}{|l|l|l|l|l|l|l|}
\hline i & & $\ddot{u}$ & & & & u \\
\hline & e & & $\ddot{o}$ & & o & \\
\hline & & & & a & & \\
\hline
\end{tabular}

S druge strane turski jezik ima osam kratkih vokala (a, 1, o, u, e, i, ö, ü) i tri duga (â, î, û) koji se susreću samo u riječima arapskoga i perzijskoga podrijetla. U odnosu na hrvatski jezik u sustavu vokala turskoga jezika specifični su ,"“ (piše se kao i, bez točke). Pri izgovoru toga glasa jezik je podignut prema tvrdome nepcu, tj. približava se početnoj vokalskoj vrijednosti pri izgovoru hrvatskoga vokalskog „,““, „̋̈“ koji je blizak njemačkome prijeglasu

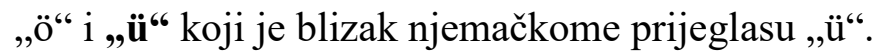

Prema sudjelovanju i položaju usana u turskome jeziku razlikujemo labijalne vokale $o$, $u$, $\ddot{o}$, $\ddot{u}$ pri čijoj su artikulaciji usne zaokružene, te nelabijalne ili neutralne $a, l, e, i$ koji se izgovaraju s usnama u neutralnome položaju (Tablica 17):

Tablica 17. Prikaz vokala u turskome jeziku

\begin{tabular}{|l|l|l|l|l|}
\hline & \multicolumn{2}{l|}{ TVRDI (zadnji) } & \multicolumn{2}{l|}{ MEKI (prednji) } \\
\hline & niski & visoki & niski & visoki \\
\hline neutralni & a & 1 & e & i \\
\hline labijalni & o & u & ö & ü \\
\hline
\end{tabular}

Prema prvome kriteriju (Čaušević 1996: 9) vokal $a$, a prema drugome kriteriju vokali $e$, $o$ spadaju u srednje vokale, kao što je to slučaj s hrvatskim vokalima $a$, $e$, i vokal $o$. Međutim, u turkologiji takva se klasifikacija manje-više ne susreće zbog toga što nema praktične 
vrijednosti za utvrđivanje tzv. zakona o vokalnoj harmoniji. Naime, uspostavljanje vokalskih parova po kriteriju stabilnost: labilnost ili palatalnost: velarnost (a:l, e:i, o:u, ö: $\ddot{u}$, odnosno: $a$, $l, o, u: e, i, \ddot{o}, \ddot{u})$ od krucijalne je važnosti za poimanje spomenutog pravila ili zakona.

Čaušević (1996: 10) zaključuje da su visoki vokali $\imath, i, u$, $u$ nestabilni i lako ispadaju iz nenaglašenoga sloga, koriste se kao protetički vokali za razbijanje inicijalnih i finalnih konsonantskih skupina u riječima stranoga podrijetla te i kao pomoćni vokali nekih sufiksa, u slučaju kad riječ završava na konsonant, a i označavaju manji stupanj akustičnoga efekta u onomatopejama i njima srodnim riječima.

Osnovno je obilježje turskih vokala njihova kratkoća. Prema mjestu tvorbe, odnosno vodoravnome položaju jezika, vokali se dijele na prednje, palatalne ili meke koje njemački autori nazivaju svijetlima - e, i, ö, ü te na stražnje, velarne ili tvrde, odnosno tamne $-\mathbf{a}, \mathbf{1}, \mathbf{o}, \mathbf{u}$. Kod velike vokalne harmonije također je važno mjesto tvorbe, u ovom slučaju stupanj uzdignutosti jezika prema nepcu, pri čemu razlikujemo visoke, labilne ili vokale klase , $\boldsymbol{i},,-\mathbf{i}$, $\mathbf{1}, \mathbf{u}, \ddot{\mathbf{u}}$ te niske ili stabilne vokale - a, e, o, ö (Čaušević 1996: 9).

Vokalna harmonija, karakteristična za turski jezik, nastaje kao posljedica aglutinacije (Čaušević 1996: 24). Naime, dolazi do glasovne prilagodbe u kojoj se drugi dio riječi prilagodi prvom i obratno. Kako u turskome jeziku nema morfema na lijevoj strani već se svi slažu isključivo na desnu, tako se i sufiksi mijenjaju u odnosu na lijevi dio riječi.

Nosetić (2013: 33) bilježi da njemački autori (Dirim 2005, Scwenk 2009) navode dva oblika vokalne harmonije: veliku i malu vokalnu harmoniju. Kod male vokalne harmonije izmjenjuju se sufiks $e$ i $a$. Ovaj se oblik vokalne harmonije primjenjuje kod tvorbe množine imenica: ev-ler (kuća - kuće), yol-lar (put-putevi), negacije: gel-me! (ne dolazi), bak-ma! (ne gledaj) i sl. Velika vokalna harmonija primjenjuje se kod brojnih nominalnih i glagolskih nastavaka. U ovom se slučaju visoki vokali, vokali klase i niski vokali izmjenjuju, tj., pravilo je da kod mekih vokala nakon vokala e/i mora slijediti vokal $i$, a nakon vokala $\ddot{o} / \ddot{u}$ slijedi $\ddot{u}$. Kod tvrdih vokala pravilo je da nakon vokala a/ı slijedi vokal $l$, (müdür (direktor) - müdür-lük (uprava)), a nakon vokala o/u vokal $u$ (bakan (ministar) - bakan-luk (ministarstvo).

U njemačkome jeziku ne postoji vokalna harmonija kao u turskome jeziku, ali postoji glasovna promjena koja se događa zbog prijeglasa i prijevoja. Prijeglas je vidljiv kod množine imenica (Baum - Bäume, Haus - Häuser), a prijevoj je prisutan u korijenu nepravilnih glagola (gehen - ging - gegangen). No, ove se dvije promjene ne mogu u potpunosti usporediti. Promjene u turskome jeziku događaju se na kraju riječi, tj. korijen se riječi ne mijenja već samo sufiksi čija je izmjena proizvoljna, ovisno o kontekstu (Čaušević 1996: 32). U njemačkom su jeziku promjene vidljive unutar riječi i njezin se korijen mijenja (Schwenk 2009: 12). 
U hrvatskome jeziku također ne postoji u pravom smislu te riječi vokalna harmonija. No, postoje samoglasničke alternacije poput prijeglasa ${ }^{216}$ (u N jd. im. s.r., npr. krilo - polje, selo - godište, kolo - Goražde, u I jd. im. m.r. i s.r, npr. gradom - mužem, selom - poljem, krilom - godištem, u množinskom umetku imenica m.r., npr. gradovi - muževi, hrastovi prištevi, grozdovi - duždevi) i prijevoja ${ }^{217}$ (a/i/u: dahnuti-dihati-duh, e/ilo: vreti-izviratiizvor, i/o/a: piti - pojiti-napajati i sl.) te alternacija ije/je ( $\mathrm{N} \mathrm{jd}$. dijete - G jd. djeteta), ijele ( $\mathrm{N}$

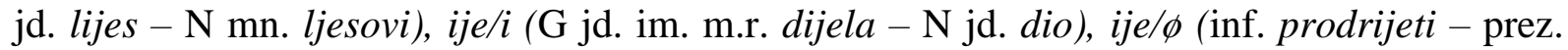
prodrem), je/i (pridj. rad. ž.r. htjela - m.r. htio), je/ije (inf. sjeći - prez. siječem), e/ije (svrš. oblik glagola letjeti - nesvrš. oblik glagola lijetati), i i/ije (svrš. oblik glagola liti - nesvrš. oblik glagola lijevati) ovisne o kvantiteti sloga ${ }^{218}$.

\subsubsection{Fonološka prilagodba posuđenica}

Transfonemizacija podrazumijeva supstituciju na fonološkoj razini, tj. zamjenu fonoloških elemenata jezika davaoca elementima jezika primaoca tijekom oblikovanja fonološkoga oblika posuđenice u jeziku primaocu. Postoje tri stupnja transfonemizacije: potpuna, kompromisna ili djelomična i slobodna transfonemizacija. Štebih-Golub (2010: 40) također ih potanko opisuje te bilježi da se ,potpuna transfonemizacija javlja kada se fonemi jezika davaoca zamjenjuju opisom identičnim fonemima jezika primaoca; do djelomične ili kompromisne transfonemizacije dolazi kada se fonemi jezika davaoca zamjenjuju fonemima jezika primaoca; a o slobodnoj transfonemizaciji govorimo kada fonološki inventar jezika primaoca ne sadrži ni djelomične artikulatorne ekvivalente fonema jezika davaoca te se oni posve slobodno zamjenjuju.“

\footnotetext{
${ }^{216} \mathrm{U}$ suvremenom je jeziku ostala produktivna samo alternacija o/e, no i ona je poremećena analogijskim i disimilacijskim procesima, pa se o javlja i iza palatalnih suglasnika, npr. Bečom, zecom; Božo, Franjo, Mićo; tuđoj, našoj; prijateljevati, prijateljovati, itd. (Barić i sur. 2005: 610).

${ }^{217}$ Barić i sur. (2005: 611) tumače da se u hrvatskome jeziku u prijevojnim alternacijama mogu pojaviti svi samoglasnici, odnosno fonemski sljedovi kao njihovi refleksi pa čak i odsutnost samoglasnika, a nekad su se javljali i svi oni samoglasnici kojih u jeziku više nema. U jednom prijevojnom nizu nikad se ne pojavljuju svi samoglasnici, a najčešće su prijevojne alternacije dvaju samoglasnika.

${ }^{218} \mathrm{U}$ suvremenome hrvatskom jeziku slogove s refleksom jata prepoznajemo po alternacijama (zamjenjivanju) reflekasa jata u raznim gramatičkim oblicima jedne riječi ili u različitim riječima izvedenima iz iste osnove. Po alternacijama slogovi se s ijekavskim refleksom jata razlikuju od slogova s primarnim fonemskim slijedom /ije/, koji s jazom nema veze i koji nikad ne dolazi u navedenim alternacijama, npr. brijem, mijem; kutije, zmije; nijedan; bijenale, orijent, itd. (Barić i sur. 2005: 609).
} 


\subsubsection{Potpuna transfonemizacija fonema}

$\mathrm{U}$ procesu potpune transfonemizacije fonemi jezika davaoca zamjenjuju se odgovarajućim fonemima jezika primaoca čiji opis udovoljava opisu fonema modela (tj. suglasnici se ne razlikuju po mjestu i načinu artikulacije, a samoglasnici po otvoru i mjestu artikulacije). U ovom stupnju prilagodbe glasovna slika njemačkih i turskih fonema podudarna je onoj u hrvatskome sustavu što je i vidljivo iz tablice (Tablica 18).

Tablica 18. Prikaz potpune transfonemizacije fonema jezika u kontaktu

\begin{tabular}{|c|c|c|c|}
\hline njemački fonem & model & hrvatski fonem & replika \\
\hline \multirow[t]{2}{*}{$/ \mathrm{a} /$} & Anzug /antsu:k/ & \multirow[t]{2}{*}{$/ \mathrm{a} /$} & ancug \\
\hline & Samt /zamt/ & & samt \\
\hline /a:/ & Eisenbahn /'aizņba:n/ & $/ \mathrm{a} /$ & ajziban \\
\hline \multirow[t]{2}{*}{ /e:/ } & Befehl /bə'fe:1/ & \multirow[t]{2}{*}{ /e/ } & befel \\
\hline & legen /'le:gņ/ & & legovan \\
\hline \multirow[t]{2}{*}{$/ 1 /$} & Zitz /'tsits/ & \multirow[t]{2}{*}{ /i/ } & cic \\
\hline & Zwicker /'tsvike/ & & cviker \\
\hline \multirow[t]{2}{*}{ /i:/ } & Ziegel /'tsi:gl/ & \multirow[t]{2}{*}{ /i/ } & cigla \\
\hline & Schlinge /'Jlina/ & & šlinga \\
\hline /o:/ & Bohren /'bo:rən/, & $/ \mathrm{o} /$ & borati \\
\hline$/ \mathrm{u} /$ & drucken /'drukn,/ & $/ \mathrm{u} /$ & natrukovan \\
\hline \multirow[t]{4}{*}{ /u:/ } & Zug /tsu:k/ & \multirow[t]{4}{*}{$/ \mathrm{u} /$} & cug \\
\hline & Bluse /blu:zə/ & & bluza \\
\hline & Uhr /u:p / & & ura \\
\hline & Urlaub /u:p人laup/ & & urlaub \\
\hline \multirow[t]{2}{*}{$/ \mathrm{b} /$} & Bluse /blu:zə/ & \multirow[t]{2}{*}{$/ \mathrm{b} /$} & bluza \\
\hline & brennen /'brenən/ & & brenati \\
\hline \multirow[t]{2}{*}{$/ \mathrm{d} /$} & dunkel /'dơkḷ// & \multirow[t]{2}{*}{$/ \mathrm{d} /$} & dunkl \\
\hline & Decke /'dekə/ & & deka \\
\hline \multirow[t]{3}{*}{$/ \mathrm{f} /$} & Farbe /'farbə/ & \multirow[t]{3}{*}{$/ \mathrm{f} /$} & farba \\
\hline & Falte /'faltə/ & & falta \\
\hline & Fleck /flek/ & & fleka \\
\hline /g/ & glänzen /'glentsņ/ & $/ \mathrm{g} /$ & glancati \\
\hline
\end{tabular}




\begin{tabular}{|c|c|c|c|}
\hline & grau /'grau/ & & graorasto \\
\hline \multirow[t]{2}{*}{$/ \mathrm{k} /$} & Kellner /'kelnø/ & \multirow[t]{2}{*}{$/ \mathrm{k} /$} & kelner \\
\hline & Kreutzer /kroytsə/ & & krajcar \\
\hline \multirow[t]{2}{*}{$/ 1 /$} & Leiter /'laity/ & \multirow[t]{2}{*}{$/ 1 /$} & lojtra \\
\hline & Lärm /lعrm/ & & larma \\
\hline \multirow[t]{3}{*}{$/ \mathrm{p} /$} & Paar /pa:ê/ & \multirow[t]{3}{*}{$/ \mathrm{p} /$} & par \\
\hline & Parade /pa'ra:də/ & & parada \\
\hline & sparen /'Jpa:rən/ & & šparati \\
\hline \multirow[t]{2}{*}{$/ \mathrm{m} /$} & Mütze /'mytsə/ & \multirow[t]{2}{*}{$/ \mathrm{m} /$} & mica \\
\hline & Pomade /po'ma:də/ & & pomada \\
\hline \multirow[t]{2}{*}{$/ \mathrm{d} /$} & Scwager /'Jva:ge/ & \multirow[t]{2}{*}{$/ \check{\mathrm{S}} /$} & šogor \\
\hline & Spange /'Jpayə/ & & špangica \\
\hline$/ \mathrm{s} /$ & Muster /'møste/ & $/ \mathrm{s} /$ & mustra \\
\hline turski fonem & model & hrvatski fonem & replika \\
\hline \multirow[t]{3}{*}{$/ \mathrm{a} /$} & alet /'a:.let/ & \multirow[t]{3}{*}{$/ \mathrm{a} /$} & alat \\
\hline & bostan/bostan/ & & bostan \\
\hline & lale/lale/ & & lala \\
\hline \multirow[t]{3}{*}{ /e/ } & meydan /mejdan/ & \multirow[t]{3}{*}{ /e/ } & megdan \\
\hline & pencere /pendzere/ & & pendžer \\
\hline & cep /dzep/ & & džep \\
\hline \multirow[t]{3}{*}{ /i/ } & dilber/dill'bæị̂ / & \multirow[t]{3}{*}{ /i/ } & dilber \\
\hline & çelik/t $\int \varepsilon l i k /$ & & čelik \\
\hline & inat/inat/ & & inat \\
\hline \multirow[t]{3}{*}{$/ \mathrm{o} /$} & çoban /tfoban/ & \multirow[t]{3}{*}{$/ \mathrm{o} /$} & čoban \\
\hline & doru+at /doru/ & & dorat \\
\hline & komşu /komfu/ & & komšija \\
\hline$/ \mathrm{u} /$ & yular/jular/ & $/ \mathrm{u} /$ & ular \\
\hline \multirow[t]{3}{*}{ /b/ } & bahçe /bah't $\int \varepsilon /$ & \multirow[t]{3}{*}{$/ \mathrm{b} /$} & bašča \\
\hline & bez /'bez/ & & bez \\
\hline & bostan /bostan/ & & bostan \\
\hline \multirow[t]{3}{*}{$/ \mathrm{d} /$} & divan/dıvan/ & \multirow[t]{3}{*}{$/ \mathrm{d} /$} & divan \\
\hline & duvar/duvar/ & & duvar \\
\hline & düşman/dyf.'man/ & & dušman \\
\hline
\end{tabular}




\begin{tabular}{|c|c|c|c|}
\hline \multirow[t]{3}{*}{ /f/ } & fes /'fes/ & \multirow[t]{3}{*}{ /f/ } & fez \\
\hline & fitil /fitíl/ & & fitilj \\
\hline & kadife /kadife/ & & kadifa \\
\hline \multirow[t]{3}{*}{$/ \mathrm{k} /$} & kalfa /kalfa/ & \multirow[t]{3}{*}{$/ \mathrm{k} /$} & kalfa \\
\hline & kalem /ka'lım/ & & kalem \\
\hline & kadife /kadife/ & & kadifa \\
\hline \multirow[t]{3}{*}{$/ \mathrm{p} /$} & para /pa'ra/ & \multirow[t]{3}{*}{$/ \mathrm{p} /$} & pare \\
\hline & top /top/ & & top \\
\hline & peşkir /pefkir/ & & peškir \\
\hline \multirow[t]{3}{*}{$/ \mathrm{s} /$} & bostan/bostan/ & \multirow[t]{3}{*}{$/ \mathrm{s} /$} & bostan \\
\hline & kayısı/kajusu/ & & kajsija \\
\hline & sini/sini/ & & sinija \\
\hline \multirow[t]{2}{*}{$/ t /$} & tarak /tarak/ & \multirow[t]{2}{*}{$/ t /$} & (o)tarak \\
\hline & $\operatorname{tavan} / \mathrm{ta} \beta \mathrm{an} /$ & & tavan \\
\hline
\end{tabular}

\subsubsection{Kompromisna transfonemizacija fonema}

U kompromisnoj ili djelomičnoj transfonemizaciji fonemi se zamjenjuju odgovarajućim fonemima jezika primaoca čiji opis samo djelomično odgovara opisu fonema modela. Filipović (1986: 72) tumači da se vokali mogu razlikovati po otvoru, ali ne i po mjestu artikulacije, a konsonanti se mogu razlikovati po mjestu, ali ne i po načinu artikulacije. Dakle, u ovom stupnju prilagodbe jedna skupina fonema njemačkoga i turskoga jezika samo se djelomično prilagođava onima u hrvatskome jeziku (Tablica 19).

Tablica 19. Prikaz kompromisne transfonemizacije fonema jezika u kontaktu

\begin{tabular}{|c|l|c|l|}
\hline njemački fonem & \multicolumn{1}{|c|}{ model } & hrvatski fonem & \multicolumn{1}{|c|}{ replika } \\
\hline \multirow{2}{*}{$/ \varepsilon /$} & Fleck /flek/ & \multirow{2}{*}{$/ \mathrm{e} /$} & fleka \\
\cline { 2 - 2 } & Decke /'dekə/ & & deka \\
\cline { 2 - 2 } & brennen /'brenən/ & brenati \\
\hline$/ \mathrm{s} /$ & Zoll /tsol/ & /o/ & col \\
\hline
\end{tabular}




\begin{tabular}{|c|c|c|c|}
\hline & Spott /Jpot/ & & špotati \\
\hline & Fräulein /'froylain/ & & frajla \\
\hline & Kreutzer /krəytsə/ & & krajcar \\
\hline & rollen /'rolən/ & & roljati se \\
\hline \multirow[t]{3}{*}{$/ \mho /$} & dunkel /'døykḷ// & \multirow[t]{3}{*}{$/ \mathrm{u} /$} & dunkl \\
\hline & lumpen /'lompn,/ & & lumpovati \\
\hline & Muster /'muste/ & & muštra \\
\hline \multirow[t]{4}{*}{$/ \mathrm{r} /$} & linieren /li'ni:rən/ & \multirow[t]{4}{*}{$/ \mathrm{r} /$} & lenjirati \\
\hline & passieren /pa'si:rən/ & & pasirati \\
\hline & schnüren /'Jny:rən/ & & šn(j)irati \\
\hline & sparen /'Jpa:rən/ & & šparati \\
\hline \multirow[t]{2}{*}{ /ç/ } & fertig /'fertıç/ & \multirow[t]{2}{*}{$/ \mathrm{h} /$} & fertih \\
\hline & richten /'riçtņ/ & & rihtati \\
\hline \multirow[t]{3}{*}{$/ \mathrm{ts} /$} & Ziegel /'tsi:gl// & \multirow[t]{3}{*}{$/ \mathrm{c} /$} & cigla \\
\hline & Zwicker /'tsvık̦̣l/ & & cviker \\
\hline & Zeiger /'tsaige/ & & cajger \\
\hline turski fonem & model & hrvatski fonem & replika \\
\hline \multirow[t]{2}{*}{$/ \mathrm{a} /$} & avlu /avlu/ & \multirow[t]{2}{*}{$/ \mathrm{a} /$} & avlija \\
\hline & baba /ba'ba/ & & babo \\
\hline \multirow[t]{2}{*}{ /e/ /ع/ } & meyhane /mejha:ne/ & \multirow[t]{2}{*}{ /e/ } & mejana \\
\hline & beden /beden/ & & bedem \\
\hline$/ \mathrm{d} /$ & çorap /t $\int$ ' $^{\prime}$ rap/, & $/ \mathrm{a} /$ & čarape \\
\hline \multirow[t]{4}{*}{$/ \mathrm{J} /$} & konak /konak/ & \multirow[t]{4}{*}{$/ \mathrm{o} /$} & konak \\
\hline & sokak/so'kak/ & & sokak \\
\hline & top /top/ & & top \\
\hline & torba /torba/ & & torba \\
\hline \multirow[t]{3}{*}{$/ 1 /$} & avlu /avlu/ & \multirow[t]{3}{*}{$/ 1 /$} & avlija \\
\hline & dilber /dinl' bæị̦/ & & dilber \\
\hline & budala /buda'la// & & budala \\
\hline$/ \mathrm{v} /$ & veresiye/veresije/ & $/ \mathrm{v} /$ & veresija \\
\hline
\end{tabular}

U hrvatskome su jeziku njemački vokali /E/, / / i / / u replikama kompromisno prilagođeni u /e/, /o/ i /u/. Položajna je varijanta njemačkoga /h/ tzv. ich-Laut/ç/ u hrvatskim 
replikama, kao što pokazuju primjeri, podvrgnuta kompromisnoj prilagodbi. Također i njemački modeli s /ts/ na početku ili na kraju riječi, gdje imaju status fonema, u hrvatskome su podvrgnuti kompromisnoj transfonemizaciji i zamijenjeni hrvatskim fonemom /c/ (Dragičević 2005: 94).

Turski fonem /1/ u riječi avlu i dilber izgovara se puno mekše nego u hrvatskome jeziku, a mijenja se i mjesto artikulacije jer je u hrvatskom /l/ alveolar dok je u turskome dental. Hrvatski fonemi /a/ i /e/ navedenih primjera otvoreniji su nego u turskome jeziku. U primjeru riječi veresiye fonem /v/ čuje se kao kombinacija glasova [vj]. Turski se vokal/o/ u hrvatskome jeziku kompromisno prilagodio u /o/ i /a/.

\subsubsection{Slobodna transfonemizacija fonema}

U stupnju slobodne transfonemizacije fonemi jezika davaoca nemaju istovrijednice $u$ jeziku primaocu pa se zamjenjuju slobodno, tj. njemački i turski glasovi kojih nema u sustavu jezika primaoca zamijenjeni su hrvatskim glasovima. Taj se tip transfonemizacije temelji na ortografiji ili na nekome izvanlingvističkom faktoru ${ }^{219}$. Što se događa s modelom u procesu slobodne transfonemizacije najbolje predočuje tablica (Tablica 20):

Tablica 20. Prikaz slobodne transfonemizacije fonema jezika u kontaktu

\begin{tabular}{|c|c|c|c|}
\hline njemački fonem & model & $\begin{array}{c}\text { hrvatski fonem/ } \\
\text { hrvatska glasovna } \\
\text { skupina }\end{array}$ & replika \\
\hline \multirow[t]{4}{*}{ /ai/ } & Eisenbahn /'aizṇba:n/ & \multirow[t]{4}{*}{ /aj/ } & ajziban \\
\hline & fein /'fain/ & & fin \\
\hline & Leiter /'lait»/ & & lojtra \\
\hline & Meister /'maiste/ & & majstor \\
\hline \multirow[t]{3}{*}{$\mid \varepsilon /$} & glänzen /'glentsņ/ & \multirow[t]{3}{*}{ /a/ } & glancati \\
\hline & Lärm /lerm/ & & larma \\
\hline & Schräge / fre:gə/ & & šaraglje \\
\hline
\end{tabular}

${ }^{219}$ Više u Filipović (1986). 


\begin{tabular}{|c|c|c|c|}
\hline \multirow[t]{3}{*}{$/ \varepsilon /$} & Arrest /a'rest/ & \multirow[t]{3}{*}{ /e/ } & rešt \\
\hline & fertig /'fertıç/ & & fertih \\
\hline & FußSocke /fu:s'zokə/ & & fusekle \\
\hline \multirow[t]{4}{*}{$/ \mathrm{a} /$} & bohren /'bo:rən/ & \multirow[t]{4}{*}{$/ \mathrm{a} /$} & borati \\
\hline & brennen /'brenən/ & & brenati \\
\hline & Decke /'dekə/ & & deka \\
\hline & Falte /'faltə/ & & falta \\
\hline \multirow[t]{2}{*}{$/ 2 /$} & Schanze /'Jantsə/ & \multirow[t]{2}{*}{ I-I } & šamac \\
\hline & Sachse /'zaksə/ & & Šokac \\
\hline \multirow[t]{2}{*}{$/ \mathrm{a} /$} & Schiene /'Ji:nə/ & \multirow[t]{2}{*}{ /e/ } & šine \\
\hline & Siebziger /'ziptsigər/ & & zipciger \\
\hline$/ \mathrm{a} /$ & Schwabe /'Jva:bə/ & $/ \mathrm{o} /$ & Švabo \\
\hline$/ œ /$ & Röcklein /rœklajn/ & /e/ & reklja \\
\hline \multirow[t]{3}{*}{ /oy/ } & Fräulein /'froylain/ & \multirow[t]{3}{*}{ /aj/ } & frajla \\
\hline & Feuerzeug /'foye'tsəyk/ & & fajercajg \\
\hline & Kreutzer / kroytsə/ & & krajcar \\
\hline \multirow[t]{2}{*}{$/ \mathrm{y} /$} & Mütze /'mytsə/ & \multirow[t]{2}{*}{ /i// } & mica \\
\hline & bügeln /'by:gln/ & & peglati \\
\hline \multirow[t]{5}{*}{$/ \mathrm{e} /$} & Bauer /'baup/ & \multirow[t]{5}{*}{$/ \mathrm{r} /$} & paor \\
\hline & Zeiger /'tsaige/ & & cajger \\
\hline & Leiter /'laite/ & & lojtra \\
\hline & Meister /'maiste/ & & majstor \\
\hline & Sechser /'zekse/ & & sekser \\
\hline \multirow[t]{4}{*}{$/ \mathrm{y} /$} & Vorhang / fo:ehay/ & \multirow[t]{4}{*}{$/ \mathrm{y}+\mathrm{g} /$} & firanga \\
\hline & Deckung /dekoy/ & & dekung \\
\hline & Strang / $\int \operatorname{tray} /$ & & štranga \\
\hline & Spange /'Jpayə/ & & španga \\
\hline$/ \mathrm{pf} /$ & Strumpf / /trumpf/ & $/ \mathrm{f} /$ & štrimfle \\
\hline turski fonem & model & hrvatski fonem & replika \\
\hline \multirow[t]{4}{*}{$/ \mathrm{y} /$} & dükkân /dyka'n/ & \multirow[t]{4}{*}{$/ \mathrm{u} /$} & dućan \\
\hline & köprü /køp'ry/ & & ćuprija \\
\hline & kürk /cyrc/ & & ćurakle \\
\hline & düșman /dyf.'man/ & & dušman \\
\hline
\end{tabular}




\begin{tabular}{|c|c|c|c|}
\hline & güvey /gyvej/ & & đuvegija \\
\hline & lüle /lyle/ & & lula \\
\hline & müşteri /myftz'ri/ & & mušterija \\
\hline & düğme /dyyme/ & & dugme \\
\hline \multirow[t]{4}{*}{$/ \mathrm{j} /$} & yastık /jastuk/ & \multirow[t]{4}{*}{ /j/ } & jastuk \\
\hline & gayda /Jajda/ & & gajda \\
\hline & maymun /majmun/ & & majmun \\
\hline & payanda/pajanda/ & & pajanta \\
\hline \multirow[t]{5}{*}{$/ \mathrm{w} /$} & kayış /kajuf/ & \multirow[t]{5}{*}{ /i/ } & kajiš \\
\hline & rak1 / ra'ku/ & & rakija \\
\hline & âşık /a:furk/ & & ašik(ovanje) \\
\hline & bayır /bajurr/ & & bajer \\
\hline & kap1 /kapu'/ & & kapija \\
\hline \multirow[t]{2}{*}{ /w/ } & pinar /pu' nar/ & \multirow[t]{2}{*}{$/ \mathrm{u} /$} & bunar \\
\hline & yastık/jastuk/ & & jastuk \\
\hline \multirow[t]{2}{*}{$/ \varnothing /$} & kör /kør/ & \multirow[t]{2}{*}{$/ \mathrm{o} /$} & ćorav $^{220}$ \\
\hline & köşe $/ \mathrm{k} \emptyset \int \varepsilon /$ & & ćošak \\
\hline$/ \varnothing /$ & köprü /køp'ry/ & $/ \mathrm{u} /$ & ćuprija \\
\hline \multirow[t]{4}{*}{$/ \mathrm{y} /$} & ciğer /dziyer/ & \multirow[t]{4}{*}{ /g/ } & džigerica \\
\hline & ağlamak /ayłamak/ & & galama \\
\hline & beǧenmek /beyenmek/ & & obegenisati \\
\hline & düğme /dyyme/ & & dugme \\
\hline \multirow[t]{5}{*}{$/ \mathrm{t} J /$} & çerga/tferge/ & \multirow[t]{5}{*}{$/ \check{c} /$} & čerga \\
\hline & pabuç /pabutf/ & & papuča \\
\hline & harç/harts/ & & harač \\
\hline & çizme /t fizme/ & & čizme \\
\hline & çorap /t $\int \mathrm{o}^{\prime} \mathrm{rap} /$ & & čarape \\
\hline$/ \mathrm{t} \int /$ & hançer /han'tfer/ & $/ \mathrm{dž} /$ & handžar \\
\hline
\end{tabular}

Vokalizirano neslogotvorno [e] predstavlja jednu od izgovornih varijanata fonema /r/.Velarni nazal /y/ u hrvatskome je jeziku prilagođen kao glasovna skupina $/ \mathrm{y}+\mathrm{g} /$. Zanimljivo

${ }^{220}$ Pogrdni naziv za pridjev u značenju 'slijep'. 
je kako se neutralni njemački vokal /ə/ koji je u hrvatskome jeziku nepoznat kao fonem prilagođava ovisno o svojoj okolini, odnosno položaju u replici. On se kao tuđi fonem u hrvatskim riječima pojavljuje u četiri varijante, pojavljuje se kao /e/, /a/, /o/ ili se u nekim leksemima gubi.

Turski fonem /y/ u hrvatskome jeziku ne postoji i prilagođen je kao fonem /j/. Fonem /1/ također ne postoji, no prilagodio se u našem jeziku u dvjema varijantama, kao /i/ i /u/. U

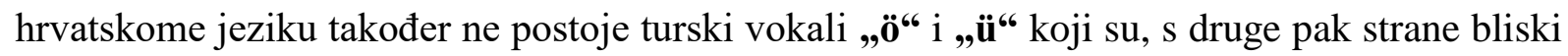
njemačkim prijeglasima „,̈“ „ü“, ali su se u hrvatskome jeziku ipak prilagodili kao fonemi. Vokal „,̈““ kao fonem /u/, a vokal „,̈“ u dvjema varijantama fonema, također kao /u/ i kao /o/. Turska konsonantska skupina /t $\mathrm{f} /$, neovisno o položaju u riječi na kojem se nalazi, u hrvatskim se replikama slobodno prilagodila $\mathrm{u} / \mathrm{c} /$ ili rjeđe u /dž/.

\subsection{Morfološka razina}

\subsubsection{Usporedba morfoloških sustava turskoga, njemačkoga i hrvatskoga jezika}

U morfološkim strukturama hrvatskoga kao pripadnika slavenskih i njemačkog kao predstavnika germanskih jezika vidljive su izvjesne podudarnosti. Kako navodi Dragičević (2005: 102) „oba jezika spadaju u sklonidbene jezike u kojima glavne vrste riječi predstavljaju imenice, glagoli i pridjevi čiji se deklinirani odnosno konjugirani oblici tvore dodavanjem odgovarajućih nastavaka osnovi.““

Turski jezik pripada grupi aglutinativnih jezika kojima je svojstvena aglutinativna morfologija ${ }^{221}$, tj. izražavanje gotovo svih gramatičkih kategorija pomoću sufiksa. Pri aglutinaciji korijen i osnova ne podliježu bilo kakvom vidu promjene, izuzevši slučajeve ozvučenja finalnog fonema i transformaciju finalnog $/ \mathrm{k} / \mathrm{u} / \mathrm{g} /$. Sufiksi su standardni; za svako gramatičko značenje upotrebljava se jedan te isti sufiks u više alomorfnih oblika, npr. ev-de 'u kući', avlu-da 'u dvorištu', park-ta 'u parku', sepet-te 'u korpi'. Stoga, turski jezik ne poznaje izuzetke u deklinaciji i konjugaciji, a ni striktne granice među vrstama riječi (Čaušević 1996: 59).

Njemački jezik kao i hrvatski poznaje kategorije prirodnoga spola i gramatičkoga roda, koji je u njemačkome jeziku naznačen (ne)određenim članom ispred imenice, dok turski ne

\footnotetext{
${ }^{221}$ Izražavanje gotovo svih kategorija pomoću sufiksa (korijen/osnova + pluralni sufiks + posvojni sufiks + padežni sufiks). Više u Čaušević (1996).
} 
poznaje kategoriju gramatičkoga roda, već imenice označavaju prirodni spol. Da bi se razlikovao rod, u turskome se jeziku određenim leksemima ${ }^{222}$ sugerira rod.

U svima trima jezicima glagoli se sastoje od slobodnoga i vezanoga morfema, slobodni se preuzima, a vezani supstituira domaćim dočetkom (-ati, -ariti, -irati, -ovati) tako da sve glagolske posuđenice prolaze stupanj potpune transmorfemizacije. Gramatička kategorija vida u njemačkome jeziku nije toliko naglašena kao u hrvatskome jer je uvjetovana tvorbom riječi, dok u turskome jeziku ona uopće ne postoji.

Za razliku od hrvatskoga i njemačkoga jezika u kojima se pridjevi dekliniraju prema rodu, broju i padežu, u turskome jeziku pridjevi ne primaju morfološke nastavke i ne mijenjaju se prema rodu, broju i padežu. Ne postoji pridjevska deklinacija (Čaušević 1996: 127).

\subsubsection{Morfološka prilagodba posuđenica}

$\mathrm{Na}$ temelju kompletnoga opisa morfoloških sustava jezika u dodiru možemo načiniti analizu na morfološkoj razini. Supstituciju na morfološkoj razini, tj. usklađivanje morfema jezika davaoca s morfološkim sustavom jezika primaoca nazivamo transmorfemizacijom.

Filipović (1986: 44) je u analizi engleskoga jezika i hrvatskoga jezika utvrdio, a to vrijedi i za ovu analizu, kako morfemske integracije pokazuju da se imenice preuzimaju kao imenice, da se pridjevi preuzimaju kao pridjevi, ali u malom broju, da imenice dobivaju fleksije jezika primaoca, da imenice zadržavaju sintaktički položaj imenice, da su glagoli prilagođeni prema morfološkom sustavu jezika primaoca.

\subsubsection{Nulta transmorfemizacija morfema}

Nulta transmorfemizacija, prema Filipoviću (1986: 120) provodi se „po formuli: slobodni morfem + nulti vezani morfem. “ Prema tom tipu morfološke prilagodbe usklađuju se sve vrste riječi (osim glagola) (Filipović 1979: 180). Replike njemačkih i turskih imenica i pridjeva u hrvatskome jeziku ostaju neizmijenjene što se jasno vidi u navedenim primjerima $u$ tablici (Tablica 21).

\footnotetext{
222 Čaušević (1996: 61) navodi da leksemi erkek 'muškarac', klz 'djevojka', kadın 'žena' dolaze u prepoziciji (tj. ispred imenice), npr. erkek kardeş 'brat', klz kardeş 'sestra' i dr. Označavanje ženskoga roda kod tradicionalnih zanimanja vrši se odgovarajućim leksemima (kız, kadın), koji dolaze u postpoziciji (iza imenice), rjeđe u prepoziciji, npr. temizliyeci kadın 'čistačica', hizmetçi kız 'služavka'.
} 
Tablica 21. Prikaz nulte transmorfemizacije morfema jezika u kontaktu

\begin{tabular}{|c|c|}
\hline njemački model & replika \\
\hline Zoll & col \\
\hline Zitz & cic \\
\hline Befel & befel \\
\hline Paar & par \\
\hline Arrest & rešt \\
\hline dunkl & dunkl \\
\hline braun & braon \\
\hline $\mathrm{Zug}$ & cug \\
\hline Anzug & ancug \\
\hline Spitz & špic \\
\hline turski model & replika \\
\hline bez & bez \\
\hline alem & alem \\
\hline duvar & duvar \\
\hline konak & konak \\
\hline top & top \\
\hline inat & inat \\
\hline tavan & konak \\
\hline sokak & sokak \\
\hline taban & taban \\
\hline saat & sat \\
\hline bostan & bostan \\
\hline çelik & čelik \\
\hline çoban & čoban \\
\hline divan & divan \\
\hline cep & džep \\
\hline fes & fes \\
\hline kayış & kajiš \\
\hline maymun & majmun \\
\hline
\end{tabular}




\subsubsection{Kompromisna transmorfemizacija morfema}

Kompromisna transmorfemizacija obuhvaća posuđenice tipa: slobodni morfem + strani vezani morfem (koji se nastoji zamijeniti domaćim morfemom), ali ni ne mora pa to znači importaciju vezanoga morfema koji postaje produktivnim u jeziku primaocu. To su replike modela muškoga roda sa sufiksima -er te pridjev sa sufiksom -ig koji je u hrvatskome jeziku nepoznanica.

Tablica 22. Prikaz kompromisne transmorfemizacije morfema jezika u kontaktu

\begin{tabular}{|l|l|}
\hline \multicolumn{1}{|c|}{ njemački model } & \multicolumn{1}{|c|}{ replika } \\
\hline Zeiger & cajger \\
\hline Zwicker & cviker \\
\hline Maler & moler \\
\hline Sechser & sekser \\
\hline Schuster turski model & šuster \\
\hline fertig & fertig/ik \\
\hline & \\
\hline dilber & dilber \\
\hline kiler & kiljer \\
\hline pencere & pendžer \\
\hline bayır & bajer \\
\hline şeker & šećer \\
\hline
\end{tabular}

\subsubsection{Potpuna transmorfemizacija morfema}

U stupnju potpune transmorfemizacije strani se vezani morfem zamjenjuje domaćim morfemom, a rezultat je replika koje je potpuno integrirana u sustav jezika primaoca. U hrvatskome se jeziku njemački i turski sufiksi zamjenjuju hrvatskim sufiksima ili se na osnovu replike dodaju hrvatski sufiksi $(-e l>-l a$, -le, $-e,-\phi>-a,-e r>-r a$, -ieren > -irati, $-\phi>-a n a,-e$ $>-a,-\iota>-j a)$ što je vidljivo iz primjera (Tablica 23). 
Tablica 23. Prikaz potpune transmorfemizacije morfema jezika u kontaktu

\begin{tabular}{|c|c|}
\hline njemački model & replika \\
\hline Wirthaus & birtija \\
\hline Zwickel & cvikle \\
\hline Bügel & pegla \\
\hline Fleck & fleka \\
\hline Falte & falta \\
\hline Spange & španga \\
\hline Leiter & lojtra \\
\hline Uhr & ura \\
\hline Strumpf & štrimfle \\
\hline Röcklein & reklja \\
\hline passieren & pasirati \\
\hline linieren & lenjirati \\
\hline schnüren & šnjirati \\
\hline spazieren & špancirati \\
\hline turski model & replika \\
\hline kireç & krečana \\
\hline veresiye & veresija \\
\hline rak1 & rakija \\
\hline harç & (h)arčiti \\
\hline pazar & pazariti \\
\hline kör & ćorav \\
\hline köşe & ćošak \\
\hline avlu & avlija \\
\hline bekri & bekrija \\
\hline kürk & ćurakle \\
\hline köprü & ćuprija \\
\hline yaban & jabana \\
\hline erguvan & jorgovan \\
\hline kadife & kadifa \\
\hline kay1s1 & kajsija \\
\hline
\end{tabular}




\begin{tabular}{|l|l|}
\hline kap1 & kapija \\
\hline kahve & kava \\
\hline
\end{tabular}

\subsection{Semantička razina}

Kad se neka strana riječ (model) preuzme u jezik primalac, pored prilagodbe na fonološkoj i morfološkoj razini događa se i prilagodba njezina značenja. Dakle, model prolazi i kroz semantičku prilagodbu. Filipović (1986: 155) tumači kako je semantičko posuđivanje proces u kojem se nova značenja dodaju starim značenjima tradicionalnih riječi.

Kao rezultat jezičnog kontakta na semantičkoj razini javljaju se dvije pojave: prilagodba značenja modela koja se događa na posuđenici koja je preuzeta iz jezika davaoca i semantičko posuđivanje koje podrazumijeva prijenos značenja iz jezika davaoca na već postojeću domaću riječ u jeziku primaocu. Filipović (1986: 153) tvrdi da se na semantičkoj razini pri tome lako može uočiti kako posuđenica prilikom integracije u sustav jezika primaoca oblikuje svoja značenja, kako se to značenje posuđenica odnosi prema značenju modela u jeziku davaocu te do kakvih je promjena u procesu prilagodbe došlo i zašto.

Preuzeta riječ u jeziku davaocu može imati ili ima više značenja, no kada ju preuzmu govornici jezika primaoca radi potrebe imenovanja određenoga novog predmeta, pojma ili pojave, ona slijedi opću tendenciju suženja značenja, tj. jezik primalac preuzima iz jezika davaoca s tom riječi samo jedno njezino značenje. To je primarna prilagodba i javlja se u trenutku prijenosa neke riječi iz jezika davaoca u jezik primalac. Svaka druga promjena na toj integriranoj posuđenici nakon njezine integracije $\mathrm{u}$ jezik primalac tijekom njezine upotrebe odnosi se na sekundarnu prilagodbu, a njezino značenje može proći i kroz nekoliko sekundarnih promjena.

$\mathrm{U}$ procesu prijelaza modela $\mathrm{u}$ repliku postoje određeni tipovi semantičkih promjena pomoću kojih bi se mogli kategorizirati stupnjevi semantičke sličnosti. One mogu biti prema Hopeu (1960: 133) promjene u semantičkoj ekstenziji, elipsa, promjena imena mjesta i vlastitih imena u opće imenice, pejorizacija (derogacija) i metafora. Taj postojeći Hopeov sustav Filipović je poboljšao uvodeći nešto precizniju podjelu u "promjene u semantičkoj ekstenziji". Dakle, prema Filipoviću (1986: 56) donesena je promjena u broju značenja i unutar jednog polja značenja pa ih je u konačnici autor naveo i objasnio ovim redoslijedom ${ }^{223}$ : ${ }^{223} \mathrm{U}$ ovom će se radu prednost dati upravo toj preciznijoj podjeli semantičkih promjena ne bi li se jasnije prikazala
i sama prilagodba posuđenica u jeziku primaocu. 
a) nulta semantička ekstenzija

b) suženje značenja po broju i u polju

c) proširenje značenja po broju i u polju.

Dakle, promjena starog značenja neke riječi u novo značenje događa se na dvije razine; na razini opsega značenja i na razini procjene značenja. Promjene se opsega značenja riječi na prijelazu u novo po Filipoviću (1986: 160) svrstavaju u tri kategorije kao što i navedeni redoslijed pokazuje. Opseg staroga značenja može ostati nepromijenjen u novom značenju pa će se ta promjena svrstati u nultu semantičku ekstenziju, novo značenje može biti suženo u usporedbi sa starim ili prošireno prema opsegu staroga značenja te kao takvo pripada kategoriji proširenja značenja po broju i u polju. Sve tri vrste promjena opsega značenja pojedinih riječi $\mathrm{u}$ jednom jeziku javljaju se $\mathrm{u}$ trenutku prijenosa modela $\mathrm{u}$ repliku tijekom procesa jezičnoga posuđivanja.

Procjena se značenja u sklopu promjene značenja može kretati u smjeru pogoršanja značenja, tj. može doći do pejorizacije ili obrnuto, pak do amelioracije kada se procjena značenja kreće u pravcu poboljšanja staroga značenja neke posuđene riječi. U procesu jezičnoga posuđivanja češća je pejorizacija, tj. razvoj prema pogoršanju značenja posuđenice dok se primjeri amelioracije ne pojavljuju u ovoj analizi njemačkih i turskih posuđenica.

\subsubsection{Semantičke promjene i njezini uzroci, priroda i posljedice na značenje posuđenica $^{224}$}

Ne bi li se jasnije shvatila priroda promjene značenja posuđenice, potrebno je proučiti osim posljedice promjene i njezine uzroke i prirodu promjene značenja posuđenice. Uzroci mogu biti raznoliki; lingvistički, povijesni, socijalni, psihološki, kakav strani utjecaj te potreba za novom riječi. Potreba za novome riječi najčešći je uzrok u imenovanju nekoga novog predmeta, pojma, pojave ili ideje i može se zadovoljiti jednim od triju postupaka navodi Filipović (1986: 158) i to „tvorbom nove riječi od postojećih elemenata jezika, posuđivanjem riječi iz nekoga drugog stranog jezika, mijenjanjem značenja postojeće stare riječi u jeziku ili dodavanjem novog značenja starom značenju riječi.“ Od navedenih triju postupaka većina

\footnotetext{
${ }^{224} \mathrm{O}$ prikazu semantičkih promjena na posuđenici te procesu prilagodbe kroz primarnu i sekundarnu adaptaciju, odnosno o opisu tranfonemizacije, transmorfemizacije i semantičkoga primanja posuđenice kao i detaljnoj analizi povijesti neologije i neologizama te njihovom normiranju više u Milković (2010).
} 
posuđenica u jezicima primaocima pripada kategoriji posuđivanja naziva za neki predmet, pojam ili pojavu iz jezika davaoca.

U procesu jezičnoga posuđivanja ta se strana riječ prilagodi i integrira u jezik primalac. Bez obzira koji su uzroci promjene značenja uvijek postoji određena jača ili slabija veza između staroga i novoga značenja. Filipović (1986: 159) dokazuje da je u svim tim slučajevima asocijacija - veza ne samo osnova cijelog procesa već i uvjet za semantičku promjenu. Nadalje, tvrdi da ,ako semantičke promjene kategoriziramo prema elementima tradicionalne analitičke definicije značenja koja se zasniva na odnosu između simbola (imena) i značenja, dobivamo dvije kategorije promjene značenja, tj. one temeljene na vezi između značenja i one temeljene na vezi između oblika. Pridruži li se toj kategoriji i podjela asocijacija na asocijaciju po sličnosti i asocijaciju po povezanosti, dobit će se četiri osnovna tipa semantičkih promjena:

1. metafora - sličnost po značenju

2. metonimija - povezanost po značenju

3. pučka etimologija - sličnost po obliku

4. elipsa - povezanost po obliku.“

\subsubsection{Prilagodba posuđenica}

Primarnoj prilagodbi pripada i nulta semantička ekstenzija u kojoj nema razlike u značenju između modela i replike. Toj istoj prilagodbi pripada i suženje značenja po broju i u polju koje se temelji na promjeni od više značenja u jeziku davaocu na jedno značenje u jeziku primaocu ili od općeg značenja modela u jeziku davaocu na specijalizirano značenje posuđenice u jeziku primaocu. Suženje značenja po broju i u polju vrlo je često u procesu prilagodbe i primjeri su mnogobrojni.

Proširenje značenja po broju i u polju, koje je uvjetovano dužom upotrebom posuđenica u jeziku primaocu, pripada sekundarnoj prilagodbi posuđenica.

Sekundarne promjene mogu se pojaviti i kroz nekoliko stupnjeva prilagodbe. Neke riječi mogu kroz etapu primarne prilagodbe prvo smanjiti broj značenja na jedno značenje što predstavlja suženje značenja u broju te kasnije, što češćom upotrebom te posuđenice u jeziku primaocu, proći kroz sekundarnu prilagodbu i proširiti broj svojih značenja s jednoga na dva ili više dodajući originalnom stranom značenju riječi novo značenje u jeziku primaocu. 


\subsubsection{Primarna prilagodba posuđenica}

U trenutku uključivanja u jezik primalac svi su modeli, prenoseći svoje osnovno značenje/ili značenja, bili podvrgnuti prvo primarnoj prilagodbi, a tek je kasnije intenzivna uporaba kod jednog dijela izazvala proširenje broja i/ili polja značenja (Dragičević 2005: 109). Dakle, primarnim promjenama koje prate proces primarne prilagodbe pripadaju one promjene koje se javljaju od trenutka prijenosa modela iz jezika davaoca u jezik primalac sve do integracije replike u sustav tog jezika. U procesu primarne prilagodbe promatraju se modeli i kompromisne replike.

\subsection{Nulta semantička ekstenzija}

Nulta semantička ekstenzija ukazuje na nepromijenjeno značenje modela i nakon integracije u sustav jezika primaoca. Nakon što se određena posuđenica integrirala iz sustava jezika davaoca u sustav jezika primaoca ona je zadržala svoje izvorno značenje. Dakle, značenje posuđenice ostalo je nepromijenjeno i potpuno odgovara značenju modela. Da je tomu tako pokazuje i tablica u kojoj su prikazani s jedne strane izrazi njemačkoga i turskoga jezika, a prate ih i posuđenice u hrvatskome jeziku s odgovarajućim izvornim značenjima modela (Tablica 24). Primjeri posuđenice mogu biti potpuno, fonološki i morfološki, prilagođeni oblici ili oblici posuđenice mogu zadržati originalni ortografski oblik iako im je izgovor prilagođen.

Tablica 24. Prikaz posuđenica u procesu nulte semantičke ekstenzije

\begin{tabular}{|l|l|l|}
\hline \multicolumn{1}{|c|}{ njemački model } & \multicolumn{1}{c|}{ replika } & \multicolumn{1}{c|}{ značenje } \\
\hline Vortuch & fertun & pregača \\
\hline linieren & linirati & povući/povlačiti ravne crte, linirati \\
\hline Leiter & lojtra & ljestve, reg. lojtre \\
\hline Kellner & kelner & konobar \\
\hline Zeiger & cajger & kazaljka \\
\hline Maschinengewehr & mašingever & strojnica \\
\hline Heller & heler & najsitniji novac nekadašnje Austro-Ugarske \\
\hline Mütze & mica & kapa \\
\hline Strumpf & štrimfle & čarape \\
\hline Sparherd & šporet & štednjak \\
\hline
\end{tabular}




\begin{tabular}{|c|c|c|}
\hline Trompete & trumbeta & truba \\
\hline Zitz & cic & $\begin{array}{l}\text { cic (vrsta pamučnog platna s figuricama i } \\
\text { šarama u boji) }\end{array}$ \\
\hline turski model & replika & značenje \\
\hline erguvan & jorgovan & jorgovan (ukrasni grm iz porodice maslina) \\
\hline kalfa & kalfa & obrtnički pomoćnik, djetić \\
\hline zerrin kadeh & zelenkada & sunovrat, narcis, ovčica, baljučka \\
\hline pencere & pendžer & prozor \\
\hline bahçe & bašča & bašča, vrt \\
\hline kaşik & kašika & žlica \\
\hline köprü & ćuprija & most \\
\hline kopça & kopča & kopča \\
\hline sümbül & zumbul & hijacint (cvijet); zovu ga i carević \\
\hline cep & džep & džep \\
\hline avlu & avlija & dvorište \\
\hline gerdan & đerdan & ogrlica \\
\hline yaban & jabana & tuđina, inozemstvo \\
\hline kayıs1 & kajsija & kajsija \\
\hline fes & fes & fes (crvena kapa osobitog oblika) \\
\hline şimşir & šimšir & zelenika (vrsta zimzelene biljke) \\
\hline helva & halva & $\begin{array}{l}\text { halva (vrsta orijentalne poslastice od brašna, } \\
\text { masti, masla i ulja) }\end{array}$ \\
\hline
\end{tabular}

\subsection{Suženje značenja}

Do suženja značenja posuđenice dolazi kada se iz jezika primaoca preuzme riječ u svrhu imenovanja novoga preuzetog predmeta, pojma ili pojave. Ivanetić (2000: 95) tvrdi da se najčešće sužava opseg značenja jer se u trenutku jezičnoga dodira isključuju sva potencijalna značenja situacijskim kontekstom te se riječ povezuje s dotičnim denotatom. Takve se riječi obično preuzimaju u specifičnim kontekstima pa prirodno tendiraju da prenesu u jezik primalac samo dio svoga starog značenja. To je najčešća promjena u jezičnome posuđivanju. Ona može 
značiti i specijalizaciju od općega značenja na specifično, tehničko; a to u većini slučajeva tvrdi Filipović (1986: 164) znači da se s posuđenicom prenosi samo jedno specifično značenje.

Da bi se prikazala ta česta pojava u jezičnome posuđivanju, provedena je semantička analiza turskih i njemačkih posuđenica u hrvatskome jeziku. Ta analiza treba pokazati kako se dogodilo suženje značenja u pojedinom modelu i koje je od njegovih više mogućih značenja preneseno s replikom u jezik primalac.

Broj značenja modela koji se suzuje uzet je iz pet rječnika. Za njemačke posuđenice poslužio je Deutsch-kroatisches universalwörterbuch iz 2005. godine, a za turske posuđenice korišteni su Turkish Concise Dictionary iz 2010. godine, Temeljni tursko-hrvatski rječnik iz 2010. te Turecko-russkij slovar iz 1977. Radi lakšeg uspoređivanja značenja unutar jezika u kontaktu koristio se i Türkisch-deutsches Wörterbuch iz 1972. godine.

Ukupan broj značenja navedenih u rječnicima služi kao polazište u određivanju suženja (ili proširenja) značenja posuđenica. Uz model naznačen je ukupan broj značenja iz rječnika, a uz repliku naveden je redni broj značenja iz rječnika koje je replika preuzela od modela.

\subsection{Suženje broja značenja}

U procesu suženja broja značenja posuđenica iz jezika davaoca prenosi u jezik primalac jedno specifično značenje, no dogodi se da pojedine posuđenice prenesu u jezik primalac i više od jednoga značenja. Navedene promjene jasno su uočljive u navedenoj tablici (Tablica 25).

Tablica 25. Prikaz posuđenica u procesu suženja broja značenja

\begin{tabular}{|l|l|l|l|}
\hline njemački model & značenje & replika & značenje \\
\hline Eisenbahn (3) & $\begin{array}{l}\text { 1. željeznica, vlak; 2(a) željeznička pruga, } \\
\text { tračnice, 2(b) željeznička pruga, željeznička } \\
\text { linija; 3. željeznica, željeznička služba }\end{array}$ & ajziban & $\begin{array}{l}\text { željeznica, } \\
\text { vlak (1) }\end{array}$ \\
\hline Dekung (7) & $\begin{array}{l}\text { 1(a) češć. vojn. zaklon, sklonište; zaštita, } \\
\text { obrana, pokrivanje; 1(b) zatajivanje, } \\
\text { skrivanje; šutnja; 2. namirenje, } \\
\text { zadovoljenje [potreba], 3(a) trg. pokriće, } \\
\text { 3(b) plaćanje, pokrivanje; 4. podudaranje, }\end{array}$ & zaklon, rov \\
\end{tabular}




\begin{tabular}{|c|c|c|c|}
\hline & $\begin{array}{l}\text { podudarnost, suglasnost, usklađenost; 5(a) } \\
\text { šport. pokrivanje [igrača], 5(b) obrana; } 6 \text {. } \\
\text { parenje [životinja], 7. rij. zaštitni sloj, } \\
\text { pokrov }\end{array}$ & & \\
\hline Falta (3) & $\begin{array}{l}\text { 1. nabor, razg. falda, falta; 2. bora, brazda; } \\
\text { 3. geol. bora, borani sloj }\end{array}$ & falta & nabor (1) \\
\hline häkeln (2) & $\begin{array}{l}\text { 1. kukičati, razg. heklati; 2. međusobno se } \\
\text { bockati, podbadati }\end{array}$ & heklati & heklati (1) \\
\hline Strang (3) & $\begin{array}{l}\text { 1(a) uže, konopac, razg. štrik, reg. štranga, } \\
\text { (b) uzde; 2(a) svitak (vune), (b) snop, (c) el. } \\
\text { ogranak, odvojak; 3. odvojak, kolosijek }\end{array}$ & $\begin{array}{l}\text { štranga, } \\
\text { štranjga }\end{array}$ & $\begin{array}{l}\text { debelo uže } \\
\text { (1a) }\end{array}$ \\
\hline fein $(8)$ & $\begin{array}{l}\text { 1. tanak, tanan, fin; 2. nježan (profil); 3. fin, } \\
\text { sitan (šećer); 4. istančan, tankoćutan, } \\
\text { profinjen, suptilan (osjećaj); 5. fin, izvrstan, } \\
\text { odličan, vrlo kvalitetan (voće); 6. razg. } \\
\text { dobar, fin, odličan (stvar); 7. razg. fin, } \\
\text { pristojan (momak); 8. elegantan, uglađen, } \\
\text { otmjen (gospodin) }\end{array}$ & fin/a/o & $\begin{array}{l}\text { fin, pristojan } \\
\text { (momak) (7) } \\
\text { i elegantan, } \\
\text { uglađen, } \\
\text { otmjen } \\
\text { (gospodin) } 8\end{array}$ \\
\hline Lampe & 1. svjetiljka, razg. lampa; 2. svjetlo & $\begin{array}{l}\text { svjetiljka, } \\
\text { lampa }\end{array}$ & $\begin{array}{l}\text { svjetiljka, } \\
\text { lampa (1) }\end{array}$ \\
\hline turski model & značenje & replika & značenje \\
\hline hayat (3) & $\begin{array}{l}\text { 1. život; življenje, 2. životan; 3. veranda, } \\
\text { trijem }\end{array}$ & vajat & $\begin{array}{l}\text { veranda, } \\
\text { trijem (3) }\end{array}$ \\
\hline duvar (2) & 1. zid; 2. barijera (prepreka) & duvar & zid (1) \\
\hline çorba (2) & 1. juha; 2. fig. zbrka, nered & juha & juha (1) \\
\hline $\operatorname{tarak}(5)$ & $\begin{array}{l}\text { 1. češalj; 2. grablje, 3(a) sprava za } \\
\text { grebenanje lana, 3(b) perje na vratu pijetla; } \\
\text { 4. krijesta; 5. rist, svod }\end{array}$ & tarak & češalj (1) \\
\hline pazar (2) & 1. trgovina, tržnica, sajam; 2. nedjelja & pazar & tržnica (1) \\
\hline kahve (2) & $\begin{array}{l}\text { 1. kava (piće za osvježenje); 2. kafić, } \\
\text { kavana }\end{array}$ & kava & kava (1) \\
\hline
\end{tabular}




\begin{tabular}{|l|l|l|l|}
\hline lüle (4) & $\begin{array}{l}\text { 1. uvojak, kovrča, pramen [kose]; 2. uvijati, } \\
\text { presavijati, okretati; 3. glineni bokal, lula; 4. } \\
\text { mlaznica vodoskoka }\end{array}$ & lula (3) \\
\hline şeker (4) & $\begin{array}{l}\text { 1. šećer, slador; 2. bombon; 3. med. } \\
\text { dijabetes; 4. drag, sladak, čaroban }\end{array}$ & šer & šećer (1) \\
\hline
\end{tabular}

\subsection{Suženje polja značenja}

Posuđenica se ne upotrebljava u jeziku primaocu u punom značenju svoga značenjskoga polja, već suzuje svoje značenjsko polje i odnosi se samo na dio značenja, isključujući ostala značenja u tom značenjskome polju. Dakle, to bi značilo da tehničko značenje posuđenice nije svedeno samo na jedno značenjsko polje već je njezina upotreba sužena i unutar tog značenjskoga polja.

Tablica 26. Prikaz posuđenica u procesu suženja polja značenja

\begin{tabular}{|l|l|l|l|}
\hline $\begin{array}{l}\text { njemački } \\
\text { model }\end{array}$ & značenje & replika & značenje \\
\hline brennen (11) & $\begin{array}{l}\text { 1. gorjeti, izgarati, biti u plamenu; 2. gorjeti, } \\
\text { žariti, peći, pržiti; 3. gorjeti, biti upaljen } \\
\text { (uključen); 4. gorjeti, peći; 5. fig. gorjeti, } \\
\text { umirati, izgarati od čega, žudjeti za čim; 6. } \\
\text { biti ljut, opeći; 7. grijati se, ložiti, 8(a) } \\
\text { paljenjem utiskivati [uzorak], propaliti, } \\
\text { progoriti, 8(b) žigosati; 9. peći, pržiti; 10. } \\
\text { zast. (za)paliti, potpaliti, potpaljivati 11. } \\
\text { uvijati kosu kovrčalom, kovrčati, reg. } \\
\text { brenati, brenovati }\end{array}$ & $\begin{array}{l}\text { uvovrčalom } \\
\text { (samo) }\end{array}$ \\
\hline Schlinge (4) & $\begin{array}{l}\text { 1. petlja, omča; 2. zamka, stupica, klopka; 3. } \\
\text { teks. petlja, omčica; 4. šport. petlja }\end{array}$ & šlinga & vezivno \\
tkivo na & bijelome \\
platnu (3)
\end{tabular}




\begin{tabular}{|l|l|l|l|}
\hline Sparherd (1) & 1. štednjak & šporet & $\begin{array}{l}\text { peć koja se } \\
\text { loži } \\
\text { isključivo } \\
\text { drvima }\end{array}$ \\
\hline turski model & značenje & replika & značenje \\
\hline ark (2) & $\begin{array}{l}\text { 1. jarak, kanal, rov za navodnjavanje, 2. } \\
\text { pomorski kanal, prokop, umjetni kanal }\end{array}$ & jarak & $\begin{array}{l}\text { (samo) mali } \\
\text { prokop, } \\
\text { kanal (2) }\end{array}$ \\
\hline âş1k (3) & $\begin{array}{l}\text { 1. biti zaljubljen; 2. ljubavnik; 3. glazbenik, } \\
\text { trubadur }\end{array}$ & ašikovanje & $\begin{array}{l}\text { (samo) } \\
\text { udvaranje, } \\
\text { ljubavno } \\
\text { razgovaranje } \\
(3)\end{array}$ \\
\hline
\end{tabular}

\subsubsection{Sekundarna prilagodba posuđenica}

Sekundarna se prilagodba odnosi isključivo na proširenje značenja replike u broju i/ili polju značenja, te označava potpuno uklapanje replike u leksički sustav hrvatskoga jezika (Stojić 2006: 57). Taj su tip prilagodbe prošle i replike nastale elipsom (povezanost po obliku), metaforom (sličnost po značenju), pučkom etimologijom (sličnost po obliku) ili metonimijom (povezanost po značenju) tijekom sekundarnih promjena. Dakle, tijekom sekundarne prilagodbe promatraju se promjene koje se javljaju na replici - posuđenici od integracije u sustav jezika primaoca nadalje.

\subsection{Proširenje značenja}

Da bi došlo do te semantičke promjene proširenja značenja, posuđenica treba zadovoljiti dva uvjeta. Dakle, kao prvo, ona mora biti potpuno integrirana u leksički sustav jezika primaoca te, kao drugo, treba joj se omogućiti slobodna upotreba, kao i svake druge domaće riječi, u okviru leksičkoga sustava jezika primaoca. Kako je interes za zadovoljenjem specifične upotrebe da se ispuni prazno mjesto u jezičnom inventaru nestao, njezin intenzitet i preciznost značenja slabi te ona ostvaruje preduvjete za širenjem ili povećanjem opsega značenja. 
Na taj se način u jeziku primaocu značenje posuđenice udaljuje od prvotne upotrebe $u$ jeziku davaocu.

\subsection{Proširenje polja značenja}

Određena se posuđenica uvedena u sustav jezika primaoca sa svojim preciznim značenjem prvo prilagodila na fonološkoj i morfološkoj razini te je imala posve određena značenja. Međutim, kada se njezina uporaba udomaćila i kad je postala dovoljno popularna, počela je gubiti svoj intenzitet značenja i širiti svoj opseg značenja uključivanjem u značenjsko polje i dodatne elemente. To znači da je u jednom određenom trenutku tijekom integracije dolazilo do proširenja značenja posuđenice.

Postoji velika vjerojatnost da posuđenica u procesu primarne prilagodbe prvo suzi svoj broj značenja, a zatim se čestom upotrebom njezino značenjsko polje proširi te ona pored prvotnoga značenja dobije i još jedno značenje.

Tablica 27. Prikaz posuđenica u procesu proširenja polja značenja

\begin{tabular}{|c|c|c|c|}
\hline njemački model & značenje & replika & $\begin{array}{l}\text { prošireno } \\
\text { značenje }\end{array}$ \\
\hline Schwabe (2) & $\begin{array}{l}\text { 1. stanovnik pokrajine } \\
\text { Schwaben; 2. nar. bubašvaba, } \\
\text { žohar }\end{array}$ & Švabo & $\begin{array}{l}\text { naziv za Nijemca } \\
\text { općenito }\end{array}$ \\
\hline Vorhang (1) & 1. zastor, zavjesa, stora & firang(l)a & isključivo zavjesa \\
\hline turski model & značenje & replika & $\begin{array}{l}\text { prošireno } \\
\text { značenje }\end{array}$ \\
\hline para (2) & $\begin{array}{l}\text { 1. novac, sitan novac, srebro; } \\
\text { 1(a) izvući novac [iz banke]; } 2 \text {. } \\
\text { fig. potrošiti novac }\end{array}$ & pare & novac, novci uopće \\
\hline peşkir (2) & 1. salveta; 2. ručnik & peškir, ručnik & $\begin{array}{l}\text { u folkl. peškir } \\
\text { kojim se kite } \\
\text { svatovi i uređuje } \\
\text { prozor kuće i } \\
\text { svatovski šator }\end{array}$ \\
\hline
\end{tabular}




\subsection{Proširenje broja značenja}

Tijekom posuđivanja određene riječi i integracijom u sustav jezika primaoca, neke posuđenice, $\mathrm{s}$ obzirom na širinu njezine uporabe, mogu proširiti $\mathrm{u}$ procesu sekundarne prilagodbe broj značenja u odnosu na prvotno značenje tijekom primarne prilagodbe. Ako se ukaže potreba za imenovanjem novog predmeta, pojma ili pojave, govornici jezika primaoca mogu posuđenici proširiti broj njezina značenja dodajući joj novo značenje. U jednom trenutku za imenovani novi predmet mogu u jeziku primaocu egzistirati dva značenja za isti predmet. Takva posuđenica u jeziku primaocu ima dodatno značenje koje je drugačije od značenja modela jezika davaoca jer $u$ jeziku davaocu taj novi predmet nema isto značenje niti postoji kao takav.

Tablica 28. Prikaz posuđenica u procesu proširenja broja značenja

\begin{tabular}{|c|c|c|c|}
\hline njemački model & značenje & replika & $\begin{array}{c}\text { prošireno } \\
\text { značenje }\end{array}$ \\
\hline Bauer (2) & $\begin{array}{l}\text { 1(a) seljak, poljodjelac, (b) razg. } \\
\text { seljačina; 2(a) šah. pješak, pijun, } \\
\text { (b) kart. dečko, žandar }\end{array}$ & Paor & $\begin{array}{l}\text { mještanin kraja } \\
\text { Paorije, okolica } \\
\text { Požege }\end{array}$ \\
\hline Schlacke (4) & $\begin{array}{l}\text { 1. ostaci izgorjelog ugljena; } 2 \text {. } \\
\text { metal. troska, drozga, šljaka; } 3 \text {. } \\
\text { geol. šljaka, porozna smjesa od } \\
\text { lave; 4. fiziol. balastne tvari, } \\
\text { celulozni sastojci }\end{array}$ & šljaka & rad, posao \\
\hline Schuster (4) & $\begin{array}{l}\text { 1. obućar, postolar; 2. žarg. pej. } \\
\text { fušer; 3. zool. reg. pauk kosac; } \\
\text { 4. šport. pet bodova [stolni tenis] }\end{array}$ & šuster & $\begin{array}{l}\text { 1. kartaška igra } \\
\text { (,lustig“), } 2 . \\
\text { nepopijeno vino, } \\
\text { tzv. pisačić } \\
\text { (Đalski) i } 3 . \\
\text { prenes. prtljanac, } \\
\text { nesposoban čovjek }\end{array}$ \\
\hline Teil (5) & $\begin{array}{l}\text { 1. dio [čega]; 2. dio, odio, } \\
\text { odlomak; 3. [pojedini] dio, } \\
\text { [pojedinačan] komad; 4. dio, }\end{array}$ & tal & $\begin{array}{l}\text { miraz, dio } \\
\text { nasljedstva koji }\end{array}$ \\
\hline
\end{tabular}




\begin{tabular}{|c|c|c|c|}
\hline & $\begin{array}{l}\text { udio; prilog, doprinos; 5. strana; } \\
\text { skupina }\end{array}$ & & $\begin{array}{l}\text { djevojka odnosi u } \\
\text { kuću mladoženje }\end{array}$ \\
\hline turski model & značenje & replika & $\begin{array}{l}\text { prošireno } \\
\text { značenje }\end{array}$ \\
\hline yular (1) & 1. povodac, oglav, uzda, vođica & ular & $\begin{array}{l}\text { šatr. zlatan ili } \\
\text { srebrn lanac za sat }\end{array}$ \\
\hline bedava (2) & $\begin{array}{l}\text { 1. besplatno, vrlo jeftino; } 2 \text {. ni za } \\
\text { šta, beskorisno }\end{array}$ & badava & $\begin{array}{l}\text { uzalud, } \\
\text { bezrazložno }\end{array}$ \\
\hline lâle (1) & $\begin{array}{l}\text { 1. lala, tulipan (cvijet iz porodice } \\
\text { ljiljana) }\end{array}$ & tulipan & $\begin{array}{l}\text { Banaćanin (naziv } \\
\text { potječe odatle što } \\
\text { su Banaćani nekada } \\
\text { nosili hlače bogato } \\
\text { izvezene ružama i } \\
\text { tulipanima) }\end{array}$ \\
\hline $\operatorname{tarak}(5)$ & $\begin{array}{l}\text { 1. češalj; 2. grablje, 3(a) sprava } \\
\text { za grebenanje lana, 3(b) perje na } \\
\text { vratu pijetla; 4. krijesta; } 5 \text {. rist, } \\
\text { svod }\end{array}$ & (o)tarak & $\begin{array}{l}\text { brdo, greben na } \\
\text { (tkalačkom stanu) }\end{array}$ \\
\hline rak1 (1) & 1. alkoholno piće od riže & rakija & $\begin{array}{l}\text { alkoholno piće od } \\
\text { raznoga voća } \\
\text { (šljive - šljivovica, } \\
\text { višnje - višnjevac, } \\
\text { oraha - orahovac i } \\
\text { sl.) }\end{array}$ \\
\hline bekâr (2) & $\begin{array}{l}\text { 1. neoženjen čovjek, samac; } 2 . \\
\text { udovac }\end{array}$ & bećar $^{225}$ & $\begin{array}{l}\text { veseo, raskalašen, } \\
\text { razuzdan čovjek, } \\
\text { vojnik najamnik iz } \\
\text { neke strane zemlje }\end{array}$ \\
\hline bekârlık (1) & 1. celibat, beženstvo, momaštvo & bećarluk & $\begin{array}{l}\text { bećarski, } \\
\text { razuzdani, samački } \\
\text { život }\end{array}$ \\
\hline
\end{tabular}

225 „I bećar u Varoši ima pogrdno značenje: '... a cura se uda za udovca il za kakog bećara, najgoreg momka, samo da ima čoeka' (Lukić 1924: 112) prema Andrić (2003: 22). 


\subsection{Metafora}

Metafora se smatra jednim od najvažnijih elemenata jezika i književnosti i opisuje jedan tip semantičkih promjena. Zbog širine i učestalosti primjene uključuje se i u sam proces jezičnog posuđivanja na semantičkoj razini. Metafora se sastoji od dva dijela; od onoga o čemu se govori i od onoga s čim se uspoređuje. Dio koji nedostaje u izričaju podrazumijeva se (Filipović 1986: 159). U tijeku sekundarne promjene prvotno značenje modela u jeziku primaocu proširuje se nekim drugim prenesenim značenjem i tada replika značenjem predstavlja pojam kojeg nema u jeziku davaocu.

Njemačka posuđenica farba (Farbe) u hrvatskome jeziku označava boju i pripada razgovornoj razini, a koristi se i u prenesenome značenju. Riječ 'farbati nekoga' pripada žargonu i znači 'lagati komu', 'varati koga' dok ista ta riječ u njemačkome jeziku nema to preneseno značenje. Riječ šljaka osim značenja 'troska, talog' u hrvatskome jeziku označava 'teški, fizički rad, posao'. Njemački je model glänzen u hrvatskome jeziku tijekom primarne prilagodbe prenio izvorno značenje 'sjati, sjajiti se, svjetlucati, blistati, ljeskati se, caliti se', a njegovom upotrebom tijekom sekundarne prilagodbe dobio je i preneseno značenje 'pretvarati se'. Na sličan način ponašala se i njemačka riječ Schuster u značenju 'obućar, postolar' koja danas metaforički označava 'nesposobnog čovjeka, prtljanca'.

Turska posuđenica bedem (beden) osim značenja 'zida, opkopa oko tvrđave', u hrvatskome se jeziku koristi i u prenesenome značenju 'ti si moj bedem', znači 'ti si moja zaštita, obrana'. Riječ tambura u hrvatskome jeziku označava žičani instrument. Od njezina korijena izveden je glagol tamburati što kod govornika hrvatskoga jezika osim osnovnoga značenja ‘svirati u tamburu' označava u prenesenome značenju 'pričati bez veze'. Turska riječ top u hrvatskome se jeziku koristi i u metaforiziranom značenju 'loša ocjena, jedinica', a to je značenje posuđenica dobila uslijed sekundarne semantičke prilagodbe. Danas ta riječ sve više poprima i značenje 'nešto je izvrsno, jako dobro'. Turski model kopça tijekom sekundarne prilagodbe i čestom upotrebom dobio je i preneseno značenje 'veza spoj uopće' kao i riječ fitilj (turski model fitil) što u sintagmi kratki fitilj označava značenje 'eksplozivan'.

\subsection{Metonimija}

Metonimija kao semantička promjena podrazumijeva ,zamjenjivanje jedne riječi drugom na temelju njihove logičke bliskosti, vremenske ili prostorne povezanosti (Bagić 2012: 
199).“Umjesto sličnosti, koja karakterizira metaforički prijenos, kod metonimije se riječ koristi „za označavanje predmeta ili svojstava koji se nalaze u egzistencijalnoj vezi s njenim uobičajenim referentom (Todorov 1987: 59). “ Bagić (2012: 202) tvrdi da se „metonimijska zamjena ostvaruje zahvaljujući cjelini koja obujmljuje upotrijebljeni i zamijenjeni pojam. Za razliku od metafore, koja povezuje različita područja, metonimijski se prijenos događa unutar istog područja.“

Preuzeta riječ iz njemačkoga jezika cimer u hrvatskome jeziku kao jeziku primaocu imala je prvotno značenje 'soba'. Danas se ta njemačka posuđenica rijetko koristi u tom značenju jer je ona sekundarnom semantičkom prilagodbom proširila svoje značenje označavajući 'sustanara' (Stojić 2006: 58). Ista se promjena dogodila i s riječju šminka. Od te riječi nastao je pojam šminker koji označava 'osobu koja drži do svojega izgleda'.

Turska riječ kaylsı (kaiš) u trenutku transfera preuzeta je u značenju 'remen', a slobodnom upotrebom nakon sekundarne prilagodbe proširila je svoje značenje označavajući i 'osobu sumnjiva morala, zelenaša, kamatara' izraženu u riječi kaišar.

\subsection{Pejorizacija}

Pejorizacija je jedan tip semantičke promjene staroga značenja riječi koje ide u pravcu pogoršanja značenja posuđenice u odnosu na prvotno značenje koje je imala u jeziku davaocu. Ta se semantička promjena u procesu jezičnog posuđivanja javlja tek u periodu kad djeluje sekundarna prilagodba, tj. kad se replika potpuno integrira u sustav jezičnoga inventara jezika primaoca.

Njemačka je riječ Zug 'vlak; potez; gutljaj', u fazi sekundarne semantičke prilagodbe, u hrvatskome jeziku proširila prvotno značenje i zatim dobila oznaku pejorativnosti: u žargonu se koristi riječ cugati u značenju 'piti alkohol', a iz istoga glagola nastala je imenica cuger ili varijanta cugaroš u značenju 'pijanac'. Njemačka je posuđenica muštra (Muster) u odnosu na osnovno značenje u jeziku davaocu proširila svoje značenjsko polje u jeziku primaocu te osim 'uzorka' može značiti i 'sumnjivog, prevrtljivog čovjeka'. Slični proces prošla je i riječ frajla (Fräulein) čije je prvotno značenje bilo 'neudana žena'. Tijekom sekundarne prilagodbe njezinom se sve većom upotrebom prvotno značenje napušta, osobito ako se nalazi u sintagmi s pridjevom star te poprima izraz s pejorativnim značenjem 'stara cura'. Njemačka posuđenica 
štimati se (stimmen) u supstandardu označava 'udvarati, nagovarati ženu na ljubavnu pustolovinu'.

Turska posuđenica majmun (maymun) preuzeta je u hrvatski jezik u osnovnom obliku 'životinja iz reda primata', ali je sekundarnom prilagodbom proširila svoje značenje i zadobila oznaku pejorativnosti: u govoru označava 'glupana', 'blesana', a od turske riječi pabuç (papuča) u našem smo jeziku izveli i izraz pejorativnoga značenja papučar 'koji je pod ženinom komandom'. Riječ Cigan koja dolazi od turskoga modela Çigene tijekom sekundarne prilagodbe uz značenja 'skitnica, lutalica, beskućnik' poprimila je i značenje 'osoba koja se cjenka'. Na isti je način i turski model kâtip prešavši u repliku ćata/ćato u jeziku primaocu u značenju 'notar, sudski pisar', poprimio svoju pejorativnu oznaku te se u hrvatskome jeziku koristi i u značenju 'pisarčić, piskaralo, pisarica'.

\subsection{Elipsa}

Elipsa se kao semantička promjena često javlja u dodiru dvaju jezičnih sustava. Ona se može manifestirati na dva načina. Iz sustava jezika davaoca može se prenijeti nepromijenjena u sustav jezika primaoca pod istim uvjetima kao svaki drugi model i podlijegati promjenama utvrđenim principima teorije jezika u kontaktu ili može doći do promjene značenja u tijeku prijenosa, tj. sačuvan element fraze preuzima značenje ispuštenoga elementa pa promjena značenja može biti velika i značajna jer ispuštanjem jednog dijela fraze zadržani dio može promijeniti i svoju vrstu riječi.

Filipović (1986: 159) navodi da u jezičnom posuđivanju elipsa ima posebnu ulogu jer su neke posuđenice rezultat prijenosa elipse iz jezika primaoca, a neke su elipse rezultat jezičnog posuđivanja. Tako replika može biti elipsa, a model puna fraza (Tablica 29).

Tablica 29. Prikaz posuđenica kao rezultat djelovanja elipse na jezike u kontaktu

\begin{tabular}{|l|l|}
\hline \multicolumn{1}{|c|}{ njemački model } & \multicolumn{1}{c|}{ hrvatska replika } \\
\hline Renstall & štala \\
\hline Bügeleisen & pegla \\
\hline Speisekammer & špajza \\
\hline Federmässer & feder (nožić) \\
\hline
\end{tabular}




\begin{tabular}{|l|l|}
\hline Gusseisen & gus (kovina) \\
\hline Spanziergang & špancir \\
\hline Wirtshaus & birtija \\
\hline Druckknopf & druker \\
\hline Strampelhöschen & štrample \\
\hline Schreibbuch & šlajbok \\
\hline Schnürsenkel turski model & šnjure \\
\hline & \\
\hline gerdanlık & đerdan hrvatska replika \\
\hline oturmak & tur (stražnjica) \\
\hline
\end{tabular}

\subsection{Pučka etimologija}

Kao semantička promjena podrazumijeva određivanje podrijetla riječi i njezina srodstva s drugim riječima istoga ili drugih jezika te povezivanje posuđenih riječi s hrvatskim glasovnim srodnicima. Tumačenje značenja riječi temelji se na sličnosti ili istovjetnosti hrvatskih riječi po obliku s riječima jezika davaoca koji se preuzimaju i prilagođavaju tijekom primarne $\mathrm{i}$ sekundarne prilagodbe.

Glagol lumpovati potječe od njemačke riječi Lump sa značenjem 'lutalica, odrpanac', ali u hrvatskom jeziku nastali glagol izveden od njemačkoga gramatičkog imena ne znači 'ponašati se kao klošar' nego 'glasno pjevajući i razbijajući čaše uživati u alkoholu'. Do pomaka u značenju vjerojatno je došlo povezivanjem posuđenog supstrata lump s hrvatskim glasovnim srodnicima lupa i lupati (Talanga 1996: 129).

Djelovanje pučke etimologije vidljivo je i na primjeru riječi pekar. Za tu riječ malo bi izvornih govornika hrvatskoga jezika reklo da je germanizam. Međutim, analizom je utvrđeno da je ta riječ posuđena iz njemačkoga jezika pri čemu se kao model pojavljuje imenica Bäcker. Oblik pekar nastao je uslijed promjene određenih glasova. Navodeći činjenice koje govore u prilog ovome tumačenju, Talanga (2002: 205) zaključuje kako je došlo do semantičkoga naslanjanja motiviranoga pučkom etimologijom na hrvatski glagol peći, koji slučajno ima slično značenje kao i njemački glagol backen pa je na taj način iščezao svaki trag posudbe iz njemačkoga jezika. 


\subsection{Leksička razina}

Pod leksičkim se posuđivanjem podrazumijeva preuzimanje leksičke jedinice, njezina izraza ili sadržaja, ili pak i izraza i sadržaja (Dabo-Denegri 1998: 441). Analizirajući leksičku razinu jezične strukture najbolje se uoče učinci jezičnih kontakata dvaju jezika.

U tradiciji jezika u kontaktu središnje mjesto zauzima upravo proučavanje leksičkih posuđenica jer ne postoji jezik koji u svojoj leksičkoj građi ne sadrži i jedinice preuzete iz drugih jezika. Dok je strukturalno strogo definirano fonološko i morfološko ustrojstvo određenog jezika, pojam jezičnog posuđivanja leksika uvjetuje otvorenost leksičkog podsustava, a olakšava ga i denotativna funkcija elemenata u podsustavu. Riječi se uvijek referiraju na izvanjezičnu stvarnost, stoga pojava novih stvari, pojmova i pojava dovodi do novih leksema bilo kreiranjem novih oblika ili njihovim posuđivanjem iz jezika davaoca. Osim toga posuđivanje stranih leksema nije strogo uvjetovano stanjem bilingvizma ili neposrednim tipom dodira prema Filipoviću, naime ono je moguće ostvariti i među vrlo udaljenim jezicima preko jezika posrednika (Matasović 2001: 69), ali i bez njegova posredstva.

Postoje različiti tipovi leksičkih posuđenica. Najčešće se posuđuju jezični znakovi u cjelini, odnosno izraz s pripadajućim sadržajem, ali je moguće posuditi i samo sadržaj. Posuđeni se sadržaj tada pridružuje već postojećoj domaćoj riječi u jeziku primaocu. U tom slučaju govori se o semantičkom posuđivanju i semantičkim posuđenicama. Poseban tip posuđivanja jest prevođenje jezičnih znakova leksičkim sredstvima jezika primaoca. Tim procesom nastaju prevedenice ili kalkovi.

\subsubsection{Klasifikacija leksičkih posuđenica}

Haugen (1950: 214-215) klasifikaciju leksičkih posuđenica provodi uzimajući u obzir sam proces preuzimanja stranih leksema razlikujući pri tome importaciju od supstitucije. Importacijom se strani jezični znakovi preuzimaju u cijelosti (Loanwords - posuđenice), a supstitucijom se strani morfemi zamjenjuju domaćima. Supstitucija može biti provedena djelomično u slučaju kada je riječ preuzeta procesom koji ujedinjuje importaciju i supstituciju morfema (Loanblends - hibridne složenice) ili potpuno bez importacije stranog morfema (Loanschifts - prevedenice i semantičke posuđenice).

U okviru teorije jezika u kontaktu Filipović (1986) govori o posuđenicama kao o najširoj kategoriji jezičnoga posuđivanja, ali spominje i pseudoposuđenice, hibridne složenice, prevedenice i semantičke posuđenice. 
U jednome od recentnijih radova iz hrvatske kontaktološke literature Piškorec (2005: 29-30) predlaže Duckworthovu klasifikaciju na Lehnwort, Lehnprägung i Lehnverbindung kao ravnopravne kategorije te stvara novu terminologiju prema kojoj imamo tri tipa posuđenica: 1 . importacijske posuđenice (posuđenice u tradicionalnom smislu) dobivene importacijom ili preuzimanjem jezičnih znakova u cijelosti; 2. supstitucijske posuđenice dobivene supstitucijom ili zamjenom stranog materijala domaćim; i 3. importacijsko-supstitucijske posuđenice dobivene djelomičnom zamjenom, odnosno kombinacijom prvih dviju strategija. U hrvatskoj jezikoslovnoj literaturi za importacijske posuđenice nalazimo i termin izravna posuđenica (Melvinger 1984: 54, Dabo-Denegri 1998: 441).

Katalinić (2013: 24) navodi kako Lanstyák predlaže novu klasifikaciju prema kojoj se sve posuđenice dijele na izravne i neizravne objedinjujući ih u skupinu primarnih posuđenica. Neizravnim posuđenicama pripadaju poluprevedenice, prevednice i semantičke posuđenice. Zasebna su skupina sekundarne (tercijarne, itd.) posuđenice u koje se ubrajaju tvorenice nastale unutarjezičnom tvorbom od primarnih posuđenica (usp. Surdučki 1978: 282), a to su hibridne izvedenice i hibridne složenice. U hrvatskoj se literaturi takvi leksemi najčešće nazivaju hibridne ili mješovite tvorenice.

\subsubsection{Zastupljenost turcizama u jeziku dvostiha}

S obzirom na povijesne uvjete, a usko povezane s njima i društvene, političke, kulturne i gospodarske aspekte dodiri tursko-osmanskoga i hrvatskoga jezika vidljivi su skoro u svim segmentima seoskoga života. Kako Andrić navodi (2003: 7) „dodir s novom kulturom i civilizacijom nije se jednako odrazio na svim područjima života. Posuđenice uglavnom pripadaju materijalnoj razini pa je najzastupljenija imenička vrsta (Vajzović 1999: 31). Pri tome se podrazumijeva da usvajanje novoga, stranog termina ili 'oznake' nije uvijek značilo i preuzimanje 'označenoga' (Vajzović 1999: 40-41), ali je sigurno nastalo kao rezultat različitih dodira i utjecaja.“

Turski-osmanski jezik kao dominantan jezik toga vremena, kada je njegov utjecaj bio daleko veći nego sada, nametao je lekseme ${ }^{226}$ koje su govornici jezika primaoca tijekom uporabe manje ili više ili u potpunosti prilagođavali hrvatskome jeziku, tadašnjem podređenijemu jeziku i u njega, uz leksičke jedinice, posuđivali i njezin izraz i sadržaj.

\footnotetext{
${ }^{226}$ Detaljnu analizu turcizama, doduše u djelima triju požeških pisaca, donose Petrović, Petranović (2013).
} 
Izdvojene riječi tursko-osmanskoga podrijetla podijeljene su prema sadržaju po područjima, tj. semantičkim poljima kako bi se lakše uočila njihova zastupljenost i utjecaj. Semantička polja obuhvaćaju: a) leksik kulinarstva, b) leksik odjevnih predmeta, ukrasa, nakita i tekstila, c) leksik kućnoga inventara i imenovanja prostora i okućnice, d) leksik botanike i vrtlarstva, poljoprivrede, obrtništva i vojništva, e) leksik pogrdnih imena, nadimaka i osobina te f) leksik međuljudskih odnosa i osjećaja.

\subsubsection{Leksik kulinarstva}

U hrvatski je jezik tijekom kontakta dvaju jezika, tj. tursko-osmanskoga kao jezika davaoca i hrvatskoga kao jezika primaoca prihvaćeno mnoštvo posuđenica i njihovih značenja za razne vrste jela, pića, raznih slastica i pripravaka čime je hrvatska kuhinja i gastronomija na taj način uvelike obogaćena. To su posuđenice: halva 'istočnjačka poslastica od brašna, meda ili šećera, masti i drugih dodataka, npr. oraha', bazlamača 'vrsta pite s mnogo vrhnja', ćufte 'jelo od isjeckana ili mljevena mesa u soku', musaka 'jelo od isjeckanog mesa, krumpira ili plavog patlidžana i riže', tarana (prema tur., a podrijetlom iz perzijskoga tarhana) 'suho tijesto zrnata oblika koje se stavlja u juhu' (Brodnjak 1992: 551), šerbet 'osvježavajuće slatko piće, medovina, medica', pekmez 'gusto ukuhano slatko voće', čorba 'naziv za juhu', džigerica 'naziv za jetru', kajmak 'vrhnje', biber 'papar', kajgana 'jelo od jaja', sarma 'mljeveno meso uvijeno u kupusovo ili lozovo lišće' te šećer, kava i čaj koje danas govornici hrvatskoga jezika uopće ne osjećaju kao posuđenice iz tursko-osmanskoga jezika.

\subsubsection{Leksik odjevnih predmeta, ukrasa, nakita i tekstila}

To su područja na kojima su također uočena i zabilježena usvajanja novih predmeta $s$ njihovim značenjem; dakle, usvajanja „označenoga“ i „označitelja“. Prihvaćanje je navedenih posuđenica poticala živa trgovina, no budući da su posuđenice predstavljale lako pokretljive predmete, njihova se zastupljenost javlja na svim područjima: od vrste tkanja: bez 'tanko platneno tkanje', kadifa u značenju materijala 'samt; baršun; pliš', čoja 'vrsta tvorničkoga čvrstog valjanog sukna, odjeća od njega' preko vrsta konca i ukrasnih niti: srma 'srebrni konac koji se upotrebljava za vez', gajtan 'predena ili pletena vrpca koja služi za porubljivanje odjeće ili za ukras' do novih vrsta pokrivača: ćebe 'pokrivač od proste vune'.

Od odjevnih predmeta i onih predmeta koji idu uz odjeću u stihovima se spominju: čarape, čizme 'obuća koja seže do koljena ili preko koljena', ćurakle 'kožuh, ogrtač podstavljen 
i opšiven krznom', fes 'kapa osobita oblika, obično crvene boje', kajiš 'remen, pojas', poša 227 'vrsta turbana, pokrivala za glavu', papuče 'vrsta lagane i udobne obuće', sandale 'laka, plitka ljetna obuća'. Andrić (2003: 20) bilježi kako je „zajedno s novim kupovnim predmetima usvojen, do tada vjerojatno nepoznat, a danas nezamjenjiv, turcizam džep. “U semantičko polje odjevnih predmeta, ukrasa, nakita i tekstila u širem smislu mogu se navesti i izrazi koji se odnose na dijelove tijela, a to su riječi tur 'stražnji dio hlača; eufem. stražnjica' i taban 'stopalo, donji dio noge'.

Turcizama ima mnogo i među nazivima za modne dodatke te ukrasne detalje na odjeći: kopča, marama i njezina umanjenica maramica, šamija 'žensko pokrivalo za glavu', dugme, torba i lepeza. Sirdžik je arsenovo (otrovno) bjelilo koje se upotrebljavalo za spravljanje pudera.

I trgovina nakitom bila je vrlo popularna te se na područje Slavonije, Baranje i Srijema donose i kupuju, ovisno o plativnoj moći, đerdani 'ogrlice', minđuše 'naušnice' i alemi 'drago kamenje'.

\subsubsection{Leksik kućnoga inventara i imenovanja prostora i okućnice}

Posuđenice, koje se mogu svrstati u područje kućnoga inventara i imenovanja prostora i okućnice, također su brojne. Uz riječi turskoga podrijetla u zagradi se navode njihove istovrijednice u hrvatskome standardnom jeziku (ako postoje). Alat 'oruđe za rad', avan 'mužar, tj. posuda za mrvljenje tvrdih stvari', avlija 'dvorište', bajer 'brijeg, strmin', bedem 'zid, nasip oko tvrđave', budžak 'ugao, kut', bunar 'studenac, zdenac', čaira 'livada, poljana', čakija 'džepni nožić', čardak ${ }^{228}$, čerga 'mali šator', čokanj ${ }^{229}$, ćošak 'ugao', ćuprija 'most', dućan 'prodavaonica, trgovina', duvar 'zid', đerma 'poluga za izvlačenje vode iz bunara', jabana 'inozemstvo, tuđina', jarak 'mali prokopani kanal', jastuk 'podglavač, uzglavlje', jorgan 'pokrivač za krevet', kapija 'velika ulazna vrata', kašika 'žlica', kavana 'ugostiteljsko mjesto u kojem se pije kava i piće', kavez 'krletka, gajba, rešetke', kiljer ${ }^{230}$ 'sobica', konak 'prenoćište, dvor', krečara 'vapnara', lula 'predmet koji služi za pušenje, sastoji se od cijevi i glave u koju se stavlja duhan', makaze 'škare', megdan 'polje, trg, sajmište', mejana 'krčma', meraja 'pašnjak', oklagija 'valjalo, rasukač, oblo drvo za razvijanje tijesta, razvijač', otarak 'češalj', pajanta 'podupirač, potporanj, greda', pazar

\footnotetext{
${ }^{227}$ Janković (1970) daje nešto drugačiju definiciju riječi poša 'vrsta kravate na staroj narodnoj nošnji'.

${ }^{228}$ Klaić (2002) navodi nekoliko definicija: '1. zgrada drvena ili zidana ili na stupovima s izbočenim drvenim gornjim katom; 2. gornji kat ili katovi u takvoj zgradi; 3. spremište za kukuruz; 4. kula stražara'.

${ }^{229}$ Klaić (2002) navodi nekoliko definicija; '1. staklenka za rakiju od 1/8 litre; 2. stabljika kupusa; 3. okomak od kukuruza, klip bez zrna', no prednost se u tekstu daje prvom značenju.

${ }^{230}$ Janković (1967) definira pojam kao 'djevojačka sobica, kućar'.
} 
'tržnica', pendžer 'prozor', peškir 'ručnik', sinija 'niski stol za blagovanje', sokak 'ulica', taraba 'ograda od dasaka', tavan 'potkrovlje', tepsija 'pladanj', vajat 'trijem, klijet, kućar', sat 'sprava za mjerenje vremena'.

U širem kontekstu navedenoga u kućama Šokaca pronalazimo i gajde ${ }^{231}$ i tamburu $^{232}$ kojima su nebrojeno puta uljepšavali svoju svakodnevicu.

Većina navedenih turskih posuđenica imaju svoje istovrijednice u hrvatskome standardnom jeziku, no i dalje su na području Slavonije, Baranje i Srijema, ponajviše u govoru staroga žiteljstva, daleko dominantnije u odnosu na njihove općeprihvaćene standardne oblike.

\subsubsection{Leksik botanike i vrtlarstva, poljoprivrede, obrtništva i vojništva}

Broj turcizama vezanih uz vrtlarstvo prilično je malen. Turskoga su podrijetla samo naziv za vrt: bašča te posuđenica bostan, 'vrt u kojem se uzgajaju lubenice i dinje ${ }^{\prime 233}$. S druge pak strane, broj je posuđenica u cvjećarstvu pozamašan. Hrvatski jezik preuzeo je posuđenice poput riječi čičak, jorgovan, jasmin, zumbul, šafran, karamfil, lala (tulipan), zelenkada (sunovrat) te nazive biljaka: šimšir, patlidžan, kukuruz i duhan.

Osmanlije su utjecale i na širenje i unapređenje voćarstva (Filipović 1970: 111). To se vidi u nazivima voća: dud, kajsija te u riječi kalamiti u značenju 'oplemenjivati voćku'. Navedeni izrazi ukazuju na to koje su biljne kulture s Osmanlijama donesene u Slavoniju, Baranju i Srijem. Od Osmanlija su ti isti žitelji upoznali i vrstu alkoholnoga pića, tzv. rakiju. Andrić (2003: 9) tvrdi kako „o nedvojbenom tursko-osmanskom utjecaju svjedoče i nazivi dijelova opreme koja se upotrebljava kod pečenja rakije: kazan, kapak i lula 'cijev kroz koju istječe tekućina'.“

Mnoštvo se imenica iz osmansko-turskoga jezika pronađenih u dvostisima odnose na pojmove iz domene poljoprivrede i obrtništva (ambar, gumno, zanat, čokot, čoban, sepet, kirija, kirijaš, kalfa, ćato, mušterija, spahija, pare, veresija, hasna). Osobito su zanimljivi i brojni nazivi za pasmine konja i konjogojstvo općenito pa se čini da naklonost prema konjima, koja se smatra dijelom identiteta Slavonaca i Srijemaca, zapravo potječe od Osmanlija (at 'pastuh, ždrijebac', dorat 'konj smeđe/tamne dlake', đokat 'konj bijelac', čilaš 'konj sive dlake s pjegama', kulaš 'konj žućkaste boje', kajasi 'remenje za upravljanje s konjima', kandžija 'bič', sersani 'konjska orma, oprema', čivija 'drveni klin', mamuza 'ostruga', ular 'povodac, vođica', češagija

\footnotetext{
${ }^{231}$ Narodni puhački instrument s mješinom i dulcem u koji se puše.

${ }^{232}$ Hrvatsko tradicijsko narodno trzalačko žičano glazbalo.

${ }^{233} \mathrm{O}$ sličnim rezultatima govori i Andrić (2003: 21).
} 
'limena četka za timarenje konja i krava', timar 'briga, nastojanje oko konja, biljaka, usjeva i sl.).

Pod semantičko polje botanike i vrtlarstva, poljoprivrede, obrtništva i vojništva mogu se svrstati i izrazi koji se odnose na vojsku (fitilj 'stijenj, žižak', top 'teško artiljerijsko oružje', tane 'topovsko zrno; metak; zrno uopće', kubura 'mala puška', handžar ${ }^{234}$, haračiti 'uništavati pred sobom').

\subsubsection{Leksik pogrdnih imena, nadimaka i osobina}

Iako se u rimovanim distisima ne pronalaze brojne pogrde, njihova je čestotnost uvelike izražena. Najviše su zastupljena pogrdna imena i atributi koji se pridaju muškarcima: (h)arambaša 'razbojnik, kradljivac; nasilnik uopće, siledžija', bećar u značenju 'veseo, raskalašen čovjek, obično ženskar, tj. koji se zna dopasti', bekrija 'pijanica, lola, propalica', budala 'glupan, ograničen, nerazborit čovjek, luda, naivčina', lola 'onaj koji je sklon veselju i piću, trošenju vremena na tjelesne užitke; ženskar; besposličar, skitnica', majmun 'nepromišljen, umno ograničen, neozbiljan, šašav čovjek', hajduk ${ }^{235}$ 'odmetnik uopće, razbojnik'. Jedan je izraz upotrebljen kako bi se označile ružne osobine u žena i djevojaka: ala 'aždaja, zmaj, napast'. Riječ u značenju 'neprijatelj, zlotvor' u jednakoj se mjeri koristi i za osobu muškoga spola dušman i za osobu ženskoga spola dušmanica.

Nisu mnogobrojni ni turcizmi kojima su se opisivale vanjske bolesti, obično prepoznavane kao mane zbog kojih je pojedinac često bio izložen ruglu zajednice. To su posuđenice: ćorav, ćosav ${ }^{236}$, sakat, jerav, šugav, muzgav. Lukić (1919: 40) tako govori o bolestima navodeći pogrdne nadimke: ,ako nema vlasi, kažu mu ćelo; ako ne vidi dobro ili ništa: ćoro;...“

Skok (1971/I: 545) je, govoreći o riječi galama, primijetio da su nazivi za smutnju, svađu i buku zaista turskoga podrijetla. U deseteračkim dvostisima spomenuti su: galama, inat, kavga, belaj. Također se u stihovima mogu pronaći i negativno konotirani glagoli: arati se, arčiti 'jediti se, uništavati se' te fentirati 'pretvarati se, hiniti'.

\footnotetext{
${ }^{234}$ Klaić (2002) definira pojam kao 'orijentalni dvosjekli bojni nož za sječenje i bodenje'.

${ }^{235}$ Klaić (2002) definira riječ i kao 'momak slobodnog ponašanja, bećarina, junak, dika (po Slavoniji)'.

${ }^{236}$ U Slavoniji se često upotrebljava pridjev ćosav kako bi se opisala osoba koja nema bradu i brkove, koja je golobrada, ali je taj izraz obično negativno konotiran i značio bi 'zelen, nedorastao, koji je neiskusan'.
} 


\subsubsection{Leksik međuljudskih odnosa i osjećaja}

Dolazeći u kontakt, pripadnici jezika davaoca i jezika primaoca uspostavljali su određene prisne odnose, u većoj ili manjoj mjeri, te se nerijetko događalo da govornici jezika primaoca s posuđenicom preuzimaju i njezino izvorno značenje ili više njih. U dvostisima tako pronalazimo riječi: babo značenja 'otac' ali i 'tast, punac; očuh' te riječ dada ${ }^{237}$ 'otac, tata'. Nadalje u stihovima dominiraju: dilber 'dragi; miljenik; ljubimac; koji osvaja; zavodnik', đuvegija 'zaručnik, mladoženja', komšija 'susjed', čelebija 'gospodin; školovan čovjek; plemić'. Pod semantičko polje međuljudskih odnosa i osjećaja mogu se svrstati i izrazi (h)ajde (od tur. haydi 'poticaj, daj, idi, pođi'), džabe u značenju 'na dar, na poklon, poklonjeno', miraz 'nasljedstvo, baština', barem (od tur. bari 'najmanje, u najmanju ruku').

U dvostisima pronalazimo i glagole kojima govornici izražavaju osjećaje poput obegenisati 'privući, zainteresirati, osvojiti, zaluditi, voljeti', ašikovati 'udvarati; voljeti se, milovati se, ljubavno razgovarati' alaliti 'oprostiti, željeti sreću' te glagol divaniti ${ }^{238}$ 'razgovarati'. Dakle, kada govornici jezika primaoca u svoj jezik prime i takve vrste posuđenica te one postanu izrazi za iskazivanje najdubljih osjećaja, razmišljanja i strepnji, može se sa sigurnošću reći da je kontakt dvaju jezika i njihovih govornika snažan, duboko isprepleten.

\subsubsection{Zastupljenost germanizama u jeziku dvostiha}

Slijedom dugogodišnjih povijesnih zbivanja ${ }^{239}$ i političkih promjena ${ }^{240}$ posuđenice njemačkoga podrijetla, tj. germanizmi su, zbog određenih kulturoloških, političkih, ekonomskih $^{241}$, socioloških i inih razloga postali jezičnom potrebom među pripadnicima doseljenoga njemačkog naroda i starosjedilačkoga stanovništva. Njihova je uporaba

\footnotetext{
${ }^{237}$ Klaić (2002) riječi dada pridružuje i značenja 'svekar' i 'tast'.

${ }^{238}$ Za momka i djevojku, koji se sastaju obično pred kućom, vele da „divane“ (Janković 1967: 157).

${ }^{239}$ Misli se na razdoblje između 16. i 19. stoljeća kad su izravni dodiri dvaju analiziranih jezika bili intenzivni. Babić (1990) navodi tri perioda unutar kojih je došlo do posuđivanja elemenata iz njemačkoga jezika. Prvi je period trajao do 1527., a drugi je trajao od 1527. do 1835. Treći je period počeo 1835. i traje sve do danas. To znači da se jezično posuđivanje odvijalo i bez izravnog dodira dviju jezičnih zajednica.

${ }^{240}$ Personalna unija (1102. - 1526.), Habsburška Monarhija i Austro-Ugarska Monarhija (1527. - 1918.). Pritom je posebna zanimljiva poveznica između reformi Marije Terezije i Josipa II. tijekom 18. stoljeća i jezičnog posuđivanja budući da je njemački jezik i u školskome sustavu Monarhije dobio status koji mu je omogućio prodiranje u hrvatski jezik (Pon 2009: 106).

${ }^{241}$ Na području Slavonije provodilo se plansko naseljavanje krajeva koji su nakon odlaska Osmanlija u 17. stoljeću ostali opustošeni, a među novim stanovništvom nalazio i nemali broj seljaka, obrtnika i trgovaca s prostora Austrije, stoga se može reći da su posuđenice njemačkoga podrijetla, veći dio njih, austrijacizmi. Usp. Binder (2006).
} 
poboljšavala međusobno sporazumijevanje, ali i potrebu govornoga iskazivanja novih elemenata izvanjezične stvarnosti uvedenih ispreplitanjem dviju kultura (Kordić 2006: 1).

Točan broj germanizam teško je utvrditi jer Babić (1990: 214-224) navodi da njemačke posuđenice nemaju sve isti status. Treba ih prvo raščlaniti prema sljedećim kriterijima: prema pravom podrijetlu, prema vremenu preuzimanja, prema stupnju prilagođenosti te statusu njemačke posuđenice u hrvatskome standardnom jeziku. U ovom radu pojam „germanizam“ koristit će se u najširem značenju, tj. za svaku posuđenicu koja je došla posrednim ili neposrednim putem s njemačkoga govornog područja u hrvatski jezik i koja je s vremenom doživjela proces prilagodbe da bi se mogla integrirati u sustav hrvatskoga jezika.

Ispitani germanizmi rimovanih dvostiha mogu se pronaći u svim područjima svakodnevnoga života poput trgovine, poljoprivrede, kulinarstva, obrta, kulture oblačenja, običajima. U stihovima su pronađeni i neki pejorativni izrazi te nekolicina slikovitih pridjeva koji opisuju ljudske osobine. Morfološki prilagođeni glagoli također su zabilježeni. Dakle, ti nam germanizmi pokazuju u kolikoj su mjeri dvije kulture i dva jezika bili međusobno prožeti te na koji su način posuđenice utjecale na jezik primalac.

Kao i turcizmi, i germanizmi su promatrani u okviru određenih semantičkih polja podijeljenih na područja koja obuhvaćaju: a) leksik kulinarstva, b) leksik odjevnih predmeta, ukrasa, nakita i tekstila, c) leksik kućnoga inventara i imenovanja prostora i okućnice, d) leksik botanike i vrtlarstva, poljoprivrede, obrtništva i vojništva, e) leksik pogrdnih imena, nadimaka i osobina te f) leksik međuljudskih odnosa i osjećaja.

\subsubsection{Leksik kulinarstva}

Germanizmi u području kulinarstva nisu brojni, no i ti neznatni primjeri pokazatelj su da je gastronomija Slavonije, Baranje i Srijema bila pod određenim utjecajem njemačkoga (austrijskog) jezika. Zanimljivi su primjeri: supa 'naziv za juhu', fruštuk 'doručak', šunka 'dimljeni ili kuhani ili sušeni svinjski but', sos 'umak', beštek 'jedači pribor', ćušpajz 'ukuhano povrće', amper-supa 'prežgana juha', ajgemaht 'juha od pilećeg mesa i povrća' te šiljer 'vrsta vina od bijelog i crnog grožđa', krofna ${ }^{242}$ 'vrsta kolača pečenog na masti'. Od glagola izdvojeni su rolati 'uvijati, savijati u krug, praviti rolu, rolnu', šopati 'toviti, silom hraniti', dinstati 'na poseban način pržiti jelo; pirjati, tušiti', ribati 'proturiti kroz ribež' i fruštukovati/fruštukati

\footnotetext{
${ }^{242}$ Uobičajen oblik za Slavoniju, no u Klaićevu rječniku (2002) naveden je oblik krafna.
} 
'doručkovati'. Uočena su samo dva pridjeva: šopan 'uhranjen nadebelo' i frižak/friška/friško 'svjež, svježa, svježe'.

\subsubsection{Leksik odjevnih predmeta, ukrasa, nakita i tekstila}

Posebno se veliki broj germanizama pojavljuje u ovom semantičkom polju što i ne čudi. Naime, utjecaj je njemačke mode na izvornu narodnu nošnju bio velik, izrazit te su naročito žene preuzimale od drugih žena i kultura modne detalje kao što su: šticne 'navlake za ručne zglobove', unterok 'ženska podsuknja', mašna 'tekstilna traka svezana u petlju', ornodla 'ukosnica', španga/šspangica 'kopča za kosu', druker 'vrsta dugmeta, kopče', štifleta 'čizma', mica 'kapa', šlajer 'veo, koprena', šlinga 'omča, petlja', šlingeraj 'vez, čipka pretežno s okruglim rupicama na platnu', cvikle 'trokutasti umetak radi proširenja tijesnog odjevnog komada', nec 'mrežasta vrsta pletiva', frosluk 'prsluk', pomada 'krema, mirisna mast za njegu lica', falta 'nabor, bora', bordura 'rub, porub, okvir', fleka 'mrlja, pjega, zakrpa', cviker 'naočale'.

Osim posuđenih naziva za modne detalje, posuđivale su se riječi i za odjeću, a najčešće su posuđenice: reklja 'kaputić', rajtozne 'muške hlače, uz koljena i listove usko priljubljene', fertun 'pregača', štrimfle 'čarape', fusekle 'dokoljenke', šlafrok 'kućna haljina', bluza 'ženski lagani gornji haljinac (samo do pasa)' ancug 'odijelo'. I tekstilna industrija obiluje germanizmima poput: mustra 'uzorak', špenadla 'probadača', rajfešlus 'patentni zatvarač', štof 'materijal, tkanina za odjeću', cic 'vrsta pamučnog platna s figuricama i šarama u boji', deka 'pokrivač', somot/somet/samt 'baršun, pliš', špic 'vrh neke tkanine, odjeće'.

Od morfološki prilagođenih glagola u stihovima dominiraju: brenovati/brenati 'kovrčati kosu brenerom', šlingati, (na)heklati 'kukičati, u ženskom ručnom radu plesti iglom kukačom', necati, štrikati 'plesti', rihtati 'namještati, popravljati', cigovati, glancati 'sjajiti, laštiti', faltati 'nabirati', (u)šnirati 'sapinjati, stezati (uzicom)', legovati 'praviti nabore na tkanini', a od pridjeva, samo ih je nekolicina u dvostisima: dunkl 'mračan', fertig 'gotov, završen', fin/fina/fino, graorast 'pepeljast, siv, prosijed', legovano 'naborano jedno preko drugoga', šlingan 'izvezen čipkom', štrikan 'pleten', natrukovan 'naštampan, tiskan'.

\subsubsection{Leksik kućnog inventara i imenovanja prostora i okućnice}

Zahvaljujući brojnim posuđenicama može se zaključiti kako je utjecaj njemačke kulture također izražen i u leksiku kućne upotrebe. To su: špajz(a) 'smočnica', ajnfort, vaga 'naprava 
za mjerenje težine', hoklica 'stolica bez naslona', šamlica, rerna 'pećnica', veš 'rublje', lampa 'svjetiljka', fraklić 'mjerica za žestoka pića, u narodu čokančić', karnišna 'zastornica', cajger 'kazaljka', ura 'sat', cintelica 'šibica, žigica', cintmašina 'upaljač', ofinger 'vješalica', šamac 'opkop', špitalj 'bolnica', štala 'staja', (a)rešt 'tamnica, zatvor' te trumbeta 'truba'.

Za neke izraze poput cokl (Sockel) govornici ne poznaju hrvatske inačice, a postoje i one koje su doživjele kroz prilagodbu i neznatne promjene: (Vorhang) firang(l)a 'zavjesa', (Bügeleisen) pegla 'glačalo', (Sparherd) šporet 'štednjak', (Wirthaus) bircuz/birtija 'gostionica' pa ih je teško povezati s izvornikom.

Glagolski oblici posuđenica pronađeni u stihovima su: peglati 'glačalo' i fajtati 'vlažiti (rublje prije glačanja)'.

\subsubsection{Leksik botanike i vrtlarstva, poljoprivrede, obrtništva i vojništva}

Germanizmi pronađeni u semantičkom polju botanike i vrtlarstva neznatni su, gotovo izostaju. U stihovima se pojavila samo nekolicina posuđenica i to za cvijeće: rozetla ' pelargonija' i fajgl 'stidljivac'.

$\mathrm{S}$ druge pak strane, germanizmi su naročito brojni u poljoprivredi i obrtništvu jer su trajnim naseljavanjem krajeva Slavonije, Baranje i Srijema njemački doseljenici sa sobom donosili i svoje obrte. Primjerice to su posuđenice: moler 'ličilac', šnajder 'krojač', šuster 'postolar', majstor 'obrtnik, zanatlija', meštar ${ }^{243}$ 'vrstan u svom zanatu; učitelj', kelner 'konobar', švigarac 244 'čuvar stada (ovaca) ili čopora (svinja)'. Od ostalih posuđenica u stihovima su pronađene: cigla 'opeka', farba 'boja', plug 'oruđe za oranje, tj. brazdanje zemlje', štranga 'debelo uže', štrajher 'čelični brus', šaraglje 'koš u kolima, zadnji dio kola', borer 'svrdlo', col 'stara mjera za dužinu, 26 mm', feder 245 'opruga', lojtre 'ljestve', frtalj 'četvrt, četvrtina', tal 'dio, udio; nasljedstvo', urlab/urlaub 'dopust, osobito u vojništvu', ajziban/ajzliban 'vlak, željeznica', zug 'vlak', šine' tračnice' te posuđenice koje se odnose na valute: heler ${ }^{246}$, sekser ${ }^{247}$, krajcar $^{248}$.

\footnotetext{
${ }^{243}$ Klaić (2002) navodi nekoliko značenja: '1. majstor, obrtnik; 2. učitelj, nastavnik; 3. šef, poglavar; 4. umjetnik (visokog dometa)'.

${ }^{244}$ Značenje pojašnjava Janković (1970) dok Klaić (2002) uopće ne navodi zapisa o toj riječi.

${ }^{245}$ Feder (njem. od Federmässer) 'sklopivi nožić na oprugu'.

${ }^{246}$ Stoti dio čehoslovačke krune.

${ }^{247}$ Novac u Austro-Ugarskoj, prvotno 6 novčića, a poslije 20 filira.

${ }^{248}$ Sitni mjedeni novac u nekadašnjoj Austro-Ugarskoj, stoti dio forinte.
} 
Befel 'zapovijed, nalog', dekung 'rov, zaklon', mašingevera ${ }^{249}$ 'strojna puška, strojnica, zipciger $^{250}$ i marškumpanija ${ }^{251}$ posuđenice su vojništva.

Proces posuđivanja izraženiji je u morfološkom smislu, primjerice u preuzimanju nekih tvorbenih nastavaka, kao infinitivnog nastavka -ovati, koji se najčešće dodaje glagolskoj osnovi posuđenoj iz njemačkoga (Kordić 2006: 6). U stihovima su pronađeni sljedeći germanizmi: štelovati 'namještati', borati 'bušiti', maljati 'slikati', molovati 'krečiti', farbati 'bojati', šicati 'pucati', šiljbočiti 'stražariti', šparati 'štedjeti', koštati 'vrijediti, imati cijenu' i lenjirati 'vući ravne crte ravnalom'.

\subsubsection{Leksik pogrdnih imena, nadimaka i osobina}

Posuđenicā kojima se označava kakvo pogrdno ime, nadimak ili osobina nema puno. One pronađene i analizirane odnose se na preneseno značenje posuđenice koja se sekundarnom prilagodbom nerijetko, u potpunosti udaljila od izvornoga značenja riječi: pauraš 'seljak, pejor. 'seljačina, prostak', Švabo '(preziran) izraz za Nijemca', frajla zast. 'ulična djevojka', prvotnoga značenja (Fräulein) 'gospođica', šljaka 'šatr. posao, rad' te izveden glagol šljakati 'raditi loše plaćen posao, biti zaposlen', cuger 'žarg. alkoholičar' i oblik glagola cugati 'piti alkohol u prekomjernim količinama', protrajbati od (treiben '(po)tjerati, (o)tjerati)) u značenju 'potrošiti sve, izgubiti', lumpovati 'pijančevati, bančiti', larma 'buka, vika', (h)uncut 'hulja, nitkov; obješenjak, vragolan', (na)cifrati se 'isticati vrline (kojih obično nema)', nacifran.

U stihovima je pronađena i jedna posuđenica koja opisuje manu slabovidnosti. Ona je $s$ vremenom postala opći porugljiv naziv za svakoga tko nosi naočale, a njezin je izraz cvikeraš.

\subsubsection{Leksik međuljudskih odnosa i osjećaja}

Zanimljivo je da se neki leksemi koriste u jednakome izvornom značenju kao u jeziku davaocu: parada 'revija', par 'dvoje nečega što spada zajedno', dok su druge riječi zadržale izvorni oblik, ali su dobile nastavak tipičan za hrvatski tvorbeni sustav: bezecirati (besetzen) 'zauzeti, zaposjednuti', pasirati (passsieren) 'odgovarati, prijati, pogodovati', špancirati

\footnotetext{
${ }^{249}$ Janković (1970) navodi primjer posuđenice gevermašina kao alternativni oblik posuđenice mašingevera. I jedan i drugi oblik riječi nosi isto značenje 'strojna puška, mitraljez'.

${ }^{250}$ Janković (1970) ih opisuje kao 'vojnici Sedamdesete regimente zajedničke vojske u Austro-Ugarskoj. U toj regimenti služili su Šokci i Srijemci'. S tim opisom slaže se i Klaić (2002), ali dodaje i značenje 'čovjek od sedamdeset godina, sedamdesetogodišnjak'.

${ }^{251}$ Klaić (2002) definira kao 'u staroj austrijskoj vojsci izraz za četu koja je bila određena za polazak na bojište'.
} 
(spazieren) 'šetati', špotati (spotten) 'rugati se, podrugivati se komu/čemu, sprdati se', štimati (stimmen) 'ugađati; biti u skladu', glancati se (glänzen) 'blistati, sjajiti se, svjetlucati', faliti (fehlen) 'manjkati, nedostajati', ofirati (höfeln) 'udvarati se; laskati, ulagivati se'.

No, u stihovima je pronađena i ona posuđenica koja se toliko prilagodila hrvatskome jeziku da ju je teško povezati s izvornikom, a to je riječ šlajbok 'lisnica' (Schreibbuch 'bilježnica').

Riječ šogor/šogorica izdvojena je zbog zanimljivog objašnjenja koji je dao Janković252 (1970) u rječniku svoje knjige, a koju navodi i Klaić (2002). Naime, i u stihovima se nazire njezino različito značenje s obzirom na rodbinske odnose objašnjene u podrubnici.

${ }^{252}$ Šogor (njem. Schwager) - 'šurjak, svak, pašanac'; šogorica - 'šurjakinja, svaja, zaova, jetrva'. „Naši izrazi u tazbinskom odnosu bogatiji su od stranih, gdje su šogor i šogorica jedine riječi za različne odnose. Posuđujemo kao bogataši od siromaka samo zato, što smo lijeni naučiti razlike i bogatstvo svog jezika. Čak i suparnike u ljubavi kadšto nazivaju šogori.“ (Janković 1970: 189). 


\section{ZAKLJUČAK}

Uvidom u korpus Lukićevih i Jankovićevih dvostiha poredbena analiza pokazala je zanimljive rezultate. Naime, iako je raščlamba provedena kroz pravopis i gramatiku starih govora te obuhvaća pojedine pravopisne, gramatičke, odnosno fonološke, morfološke, rječotvorne, sintaktičke i leksičke značajke, ne uključuje podrobnije opisivanje tih osobitosti jer to i nije bio cilj rada, ali je svakako dobar pokazatelj za daljnje proučavanje narodnoga govora unutar zadanoga korpusa. Raščlanjivanjem pojedinih navedenih značajki unutar poredbenih stihova uočene su određene preinake čiji su rezultat ili distinktivni ili identični stihovi. Takvi se rezultati doduše mogu pojasniti činjenicom da lokaliteti na kojima se prikupljala građa nisu toliko udaljeni, da vremenski odmak u kojem se prikupljala navedena građa nije znatan, odnosno da struktura deseterca, čiji se sadržaj oblikuje oko ključnih motiva, a uvjetovan je minimalizmom i rimom, nameće suženi izbor riječi unutar stihova. Je li posrijedi i neki drugi razlog, primjerice prepisivanje dijela građe moglo bi se utvrditi detaljnijom jezičnom analizom i podrobnijim terenskim istraživanjem iako pouzdanih rezultata da se utvrdi potonje ima kako je pokazala poredbena analiza korpusa.

S obzirom na količinu analiziranoga materijala koji je obuhvaćao oko 8000 rimovanih deseteraca Slavka Jankovića i Luke Lukića te premoćno više analiziranih riječi unutar samih stihova ne začuđuje da se u opisivanju osobitosti leksičkoga sustava mjesnih govora slavonskoga dijalekta s područja Slavonije, Baranje i Srijema velika pozornost posvetila i sinonimiji kao pojavi na leksičkoj razini, no nije izuzeta ni sintaktička ni tvorbena unutar koje se pojavljuje nekolicina sinonima. Naime, u opisu navedenoga semantičkoga odnosa uočen je relativno mali broj tzv. pravih sinonima dok su višestruko brojniji oni koji pripadaju područno obilježenome leksiku ili razgovornome jeziku. Iz toga razloga opisivanju sinonima pristupilo se proučavanjem sinonimičnih leksičkih jedinica unutar dijasistema i na sintagmatskoj razini jer bi svaki drugi oblik analize ponajprije osiromašio leksičko-semantički opis mjesnih govora slavonskoga dijalekta navedenoga područja, a zatim potisnuo u zaborav već ionako pomalo zaboravljen leksik.

Davanjem prostora ne samo analizi sinonima na paradigmatskoj (sinonimija) već i na sintagmatskoj (sinonimičnost) razini, upotpunjeno je jezično bogatstvo šokačkoga entiteta i stvorena prilika za pomnije istraživanje jezičnih razina u kojima se skrivaju ne samo, za ovaj rad, primarne jezične osobitosti prostora Slavonije, Baranje i Srijema nego i kulturološke i ine. 
U hrvatskome su jeziku, a to je pokazala i ova analiza, homonimi, tj. riječi koje pripadaju istoj vrsti riječi, imaju jednake fonemske oblike $\mathrm{i}$ isti naglasak u svim oblicima, relativno rijetki. Homonimija se promatrala i na razini leksema, tj. riječi u svim njezinim oblicima, ali i na razini pojedinog oblika što je u analizu uključilo i homoforme, odnosno oblične homonime, no to nije znatno povećalo njihov broj. Zanimljivo je kako je ovaj rad donio tri nova homonima i njihova značenja ( $g r l o$ 'stoka, marva', šiša 'pogrdni naziv za siromašnu osobu', slog 'preorana zemlja') koji nažalost nisu uvedeni kao natuknice u Anićev Veliki rječnik hrvatskoga jezika. U deseteračkim su dvostisima najviše dominirali homografi ili istopisnice u kojima su se kao novina izdvojili putnica 'nakupina nečistoće na koži', rubina 'pletena duga košulja ili suknja, dio nošnje', kućar 'u zadružnim kućama posebni odjeljci u kojima žive oženjeni ljudi sa ženama', šolja 'posprdni naziv za Šokca', cuga 'piće', zubiti 'usitnjavati zemlju zubačom' ili filirati 'plesti mrežu'. Također je zabilježen i neznatan broj homofona ili istozvučnica.

Koristeći se kroz analizu homonimije navedenima rječnicima, u njima su uočena $\mathrm{i}$ određena razilaženja u vidu navođenja pojedinih natuknica te njihovih naglasaka ${ }^{253}$ što je samo potvrda mnogih nedoumica povezanih s određenjem pojma homonimije i razgraničenja homonimije i polisemije. Analizom homonimije također je uočeno kako u Velikome rječniku hrvatskoga jezika Vladimira Anića nisu zabilježeni pojedini leksemi i njihova značenja kojima bi se ta ista pojava sigurno upotpunila te kako je potrebno raditi na proširivanju toga leksikografskog blaga ${ }^{254}$. Naime, ti su nezabilježeni leksemi i dalje u uporabi šokačkoga žiteljstva, i šire, i stoga ih je potrebno uvesti u postojeću rječničku građu te tako proširiti, a ujedno i obogatiti leksik hrvatskoga jezika.

Provedenom se analizom pokazalo kako u deseteračkim dvostisima prevladavaju postojeća izvedena značenja polisemnih leksema. Ona su nastala tvorbom, posuđivanjem i metonimijskim i metaforičkim proširivanjem. Proces posuđivanja daleko više diktira (čak 50\%) oblikovanje postojećih izvedenih značenja pri čemu turcizmi i germanizmi dominiraju. Od praslavenskih i staroslavenskih riječi tvorbenim postupkom nastala su izvedena prenesena značenja koja čine čak jednu trećinu izvedenoga značenja zabilježenih polisemnih leksema.

Količina zabilježenoga osnovnog značenja polisemnih leksema u odnosu na zabilježena postojeća izvedena i uočene nove nijanse polisemnih leksema neznatna je, a rezultat su također posuđivanja germanizama i turcizama. Zanimljiv je leksem švaler. U Anićevu rječniku

\footnotetext{
${ }^{253}$ Primjerice u VRHJ-u leksem pipa 'slavina' obilježen je kratkosilaznim naglaskom umjesto dugouzlaznim, a leksem pegla 'glačalo' dugosilaznim umjesto dugouzlaznim naglaskom.

${ }^{254}$ I sama Tafra (2016: 147) zaključuje: „,kako suvremeni rječnici ne mogu biti pokazatelji uzorne obrade homonima. Anić je nakon kritike prvoga izdanja (Tafra 1992), u kojem su bili obrojčani, primjerice, bït i bît, u ostalim izdanjima popravio obradu homonima."
} 
porijeklo mu je austrijsko-njemačko dok mu Klaić porijeklo dovodi u svezu s chevalier (franc. prvotno - konjanik, vitez, kasnije kavalir) koje je značenjski dosta udaljeno od značenja koje ima leksem u kontekstima deseteračkih dvostiha. Bilo bi zanimljivo proučiti kako se i kada to prvotno značenje posuđenice nijansiralo u 'ljubavnik, milosnik, dragan; ženskar, lola' koje se kao takvo beziznimno tumači u kontekstu dvostiha.

S druge pak strane polisemni leksem čoban (tur. çoban: pastir) zabilježen je u Anićevu rječniku trima natuknicama, a ni jedna ne odgovara suženome značenju leksema koje ono ima u deseteračkim dvostisima. Naime, čoban je determiniran usko specijaliziranim značenjem 'čuvar ovaca'. Potvrdu za to pronalazimo kod Jankovića i Skoka.

$\mathrm{Za}$ analizu polisemnih leksema najzanimljiviji su oni čije su nijanse značenja izvedene kontekstom deseteračkoga dvostiha unutar kojeg se pojavljuju, a do sada nisu primjerice zabilježeni unutar Anićeva rječnika kao postojeći ili su navedeni kao monosemni leksemi. Na tim je polisemnim leksemima bio i poseban naglasak. Analiza je pokazala kako se isti mogu podijeliti u dvije skupine; leksemi novih izvedenih značenja i leksemi novih izvedenih prenesenih značenja. Prva je skupina rezultat većinom posuđivanja dok je zabilježeno i nekoliko primjera nastalih tvorbom. Druga je skupina leksema nastala tvorbom, posuđivanjem i daleko više proširivanjem postojećih značenja metaforom i metonimijom.

Unutar prve skupine leksema posebno se izdvaja leksem nena čije natuknice iscrpno pojašnjava Janković, a kao leksem nije zabilježen u rječnicima. Zanimljiv je i leksem gaće (prasl. gatje). U Anićevu je rječniku monoseman, a kontekst deseteračkih dvostiha donio nam je i još jedno, tzv. novo značenje tog leksema po čemu se on može svrstati u polisemni. Leksem bi nosio značenje 'donji dio muške nošnje, tj. hlača, odjevni predmet' te se kao takav može uvrstiti u rječnik pod istom natuknicom. Leksem ašikovati (tur. âşàk: ljubiti, voljeti) Anić također bilježi kao monoseman, ali u stihovima on poprima novo značenje 'voditi ljubav' te se može smatrati polisemnim. Tu potvrdu imamo i kod Klaića.

Analizirani polisemni leksemi prve skupine donose brojne primjere kojima bi se korpus Anićeva rječnika mogao upotpuniti. Primjerice to su leksemi divan 'druženje, okupljanje mladeži i seljana', komesija/komisija 'pregovor, razgovor, dogovor', mašina 'mali uređaj za šišanje', numera 'potkućnica, tj. područje za obradu zemlje iza kuće', (o)begenisati (koga) 'privući, osvojiti, zaludjeti', pojata 'spavaonica u zadružnim kućama', pristati (što) 'odgovarati, priličiti', šamac/šanac '(veliki) kanal', voz 'seoska kola natovarena žitom' i sl.

Unutar druge skupine leksema podjednako su prisutni postupci tvorbe i posuđivanja kao postupci kroz koje su zabilježene nove nijanse postojećih značenja polisemnih leksema, a detaljno su analizirani u tablici i određeni kao nova prenesena značenja. Primjerice, to su 
leksemi: apoteka 'šminka', blago 'draga osoba, dragan', dijeliti (se) 'rastajati se', doran 'mladić', fitilj 'sitna, mršava žena; mršavica', globa 'mršavica', ker 'muško spolovilo', mušterija 'prosac, udvarač', okovati (se) 'oženiti se/udati se', politika 'lukavost, proračunatost', posije 'jeftina stvar, mala ili nikakva vrijednost čega', šilbok 'sveznalica', tambura 'trbuh', ušnirati (se) 'urediti se, lijepo se obući', vlada 'odluka, riječ', zalajati 'psovati, ružno govoriti', zapinjati za (koga) 'zanimati se za (koga)', zeleniti (se) 'ostati neženja, vječno mlad'. Posebno se ističe leksem krpilonac sa svojim prenesenim značenjem 'siromah' koji nije kao takav ili uopće zabilježen u Anićevu rječniku. No, zanimljiva je činjenica što zabilježen Anićev leksem drotar, kotlokrpa djelomično odgovara svojim značenjem Jankovićevu pojašnjenju leksema krpilonac.

Najveći broj leksema druge skupine nastao je proširivanjem postojećega značenja metaforom ili metonimijom, daleko dominantnijom u ovom radu. Kao rezultat metafore pojavili su se leksemi golub 'sin od milja, majčin sin', jarac 'vrckava, nemirna, prevrtljiva, temperamentna, tvrdoglava ličnost', lanac 'upotrebi predmet kao nakit' te venuti 'patiti za (kim)' dok su metonimijskim proširenjem nastali daleko brojniji leksemi. Na oblikovanje njihovih značenja također je utjecao kontekst deseteračkih dvostiha. To su primjerice leksemi banka 'novac općenito', braca 'mladić, muškarac općenito', grlo 'glas', orman 'odjeća, imetak u nošnji', rukavi 'oplećak, gornji dio ženske nošnje', seka '(ne)udana ženska osoba općenito', slovo 'pismo, obavijest', somet 'plišana tanka traka koja se stavlja djevojci oko vrata kao ukras', svila 'svilena rubina, vrsta suknje od svile'. Zanimljivi su u deseteračkim dvostisima primjeri leksema Srbija, Rusija, Crna Gora koji se značenjski odnose na vojnike, tj. vojsku navedenih država kao i toponimi Zbjeg i Šumeće koji su u rječnicima monosemni leksemi. No, ako im se priključi značenje 'stanovnici sela', oni postaju polisemni jer su metonimijom dobili prošireno novo značenje, ali semantički vezano uz osnovno značenje.

Deseterački dvostisi svojim su sadržajem idealan tekst za proučavanje značenja postojećih polisemnih leksema kao i za proučavanje njihovih nijansiranih značenja koja uvelike ovise o kontekstu samih stihova kako je i sama analiza pokazala. Stoga, pojedine je lekseme poželjno promatrati unutar konteksta. Naglasak je kroz ovu analizu stavljen na polisemne lekseme novih izvedenih i lekseme novih izvedenih prenesenih značenja nastalih tvorbom, posuđivanjem i proširivanjem postojećih značenja metaforom i metonimijom. Analizirani izdvojeni polisemni leksemi opisanim značenjima također mogu dopuniti rječničku bazu Anićeva rječnika te na taj način obogatiti i sam jezični sustav. 
Hrvatski je jezik, kao i ini jezici, od svoga postanka bio u neposrednome ili posrednome kontaktu s drugim jezicima, narodima i kulturama. Na te dodire utjecale su brojne političke, gospodarske, kulturne i socijalne prilike što je rezultiralo jezičnim međudjelovanjem. Ovisno o potrebi govornici su svjesno i nesvjesno preuzimali tuđi izričaj kako bi imenovali novi predmet ili pojavu. Tako se tuđi utjecaj sve više širio, prvo u pojedinim, a sve većom upotrebom u svim područjima društvene djelatnosti, te po potrebi, zbog pomodarstva ili kakvoga drugog razloga, istiskivao domaće riječi ili s njima supostojao kao sinonim.

Od svih jezika s kojima je hrvatski bio u dodiru tijekom dugoga vremenskog razdoblja najviše je dolazio u doticaj s njemačkim (7. stoljeće - 20. stoljeće) i turskim (14. stoljeće 18.stoljeće) jezikom. U tom periodu došlo je kroz izravni/neizravni kontakt domaćega stanovništva s izvornim govornicima njemačkoga i turskoga jezika do međusobnih utjecaja na svim područjima života pa tako danas germanizme i turcizme pronalazimo u velikom broju leksičko-semantičkih polja i područja.

S obzirom na povijesne uvjete, a usko povezane s njima i društvene, političke, kulturne i gospodarske aspekte dodiri tursko-osmanskoga i hrvatskoga jezika vidljivi su skoro u svim segmentima seoskoga života. Dodir s novom kulturom i civilizacijom nije se jednako odrazio na svim područjima života. Posuđenice uglavnom pripadaju materijalnoj razini pa je najzastupljenija imenička vrsta (Vajzović 1999: 31). Pri tome se podrazumijeva da usvajanje novoga, stranog termina ili „oznake“ nije uvijek značilo i preuzimanje „označenoga“(Vajzović 1999: 40-41), ali je sigurno nastalo kao rezultat različitih dodira i utjecaja.

Turski-osmanski jezik kao dominantan jezik toga vremena, kada je njegov utjecaj bio daleko veći nego sada, nametao je lekseme koje su govornici jezika primaoca tijekom upotrebe manje ili više ili u potpunosti prilagođavali hrvatskome jeziku, tadašnjem podređenijemu jeziku i u njega, uz leksičke jedinice, posuđivali i njezin izraz i sadržaj.

Izdvojene riječi tursko-osmanskoga podrijetla podijeljene su prema sadržaju po područjima, tj. semantičkim poljima kako bi se lakše uočila njihova zastupljenost i utjecaj. Semantička polja obuhvaćala su: a) leksik kulinarstva, b) leksik odjevnih predmeta, ukrasa, nakita i tekstila, c) leksik kućnoga inventara i imenovanja prostora i okućnice, d) leksik botanike i vrtlarstva, poljoprivrede, obrtništva i vojništva, e) leksik pogrdnih imena, nadimaka i osobina te f) leksik međuljudskih odnosa i osjećaja.

Analiza ispitanih posuđenica pokazala je da je tijekom povijesnih, političkih, društvenih i kulturoloških dodira dvaju naroda i dvaju jezika, tursko-osmanskoga kao jezika davaoca i 
hrvatskoga jezika kao jezika primaoca, islamizacija kao izvanlingvistička činjenica imala veliku ulogu u prihvaćanju turskih posuđenica, uz određene prateće promjene načina života, jezičnoga neprilagođavanja doseljenoga stanovništva i sl. Iz toga slijedi da je kroz tri stoljeća međusobnih doticaja, osmanlijska kultura ostavila traga, što terminološki što stvarno, u svim područjima svakodnevnoga ljudskog života, a naročito u semantičkome polju koje se odnosi na leksik kućnoga inventara, imenovanja prostora i okućnice te leksik botanike, vrtlarstva, poljoprivrede, obrta i vojništva i na taj način obogatila svakodnevnicu šokačkoga svijeta, oplemenila poljoprivredu i gospodarstvo novim kulturama i zanatima.

Veliki broj novih usvojenih riječi zastupljeni su u terminologiji vezanoj za leksik odjevnih predmeta, ukrasa, nakita i tekstila, a nešto manji broj posuđenica nosi podrugljivo značenje te označava sukobe, tjelesne mane ili ružne predmete i pojave. Najmanji broj turcizama, pronađenih u dvostisima, odnosi se na leksik gastronomije i leksik međuljudskih odnosa i osjećaja. Utjecaj osmanlijske kuhinje ne začuđava s obzirom na njihovu pripremu i apetite šokačkoga svijeta pa je pojavom novih jela hrvatska gastronomija mogla biti samo dodatno obogaćena. No, sama činjenica da se osmanlijski utjecaj proširio i na domenu osjećaja, dokaz je koliko je osmansko-turski jezik kao jezik davalac bio dominantniji i snažniji u odnosu na hrvatski jezik, jezik primalac.

Slijedom dugogodišnjih povijesnih zbivanja kao i političkih promjena i posuđenice njemačkoga podrijetla, tj. germanizmi su, zbog određenih kulturoloških, političkih, ekonomskih, socioloških i inih razloga postali jezičnom potrebom među pripadnicima doseljenoga njemačkog naroda i starosjedilačkoga stanovništva. Njihova je upotreba poboljšavala međusobno sporazumijevanje, ali i potrebu govornoga iskazivanja novih elemenata izvanjezične stvarnosti uvedenih ispreplitanjem dviju kultura (Kordić 2006: 1).

Točan broj germanizam teško je utvrditi jer Babić (1990: 214-224) navodi da njemačke posuđenice nemaju sve isti status. Treba ih prvo raščlaniti prema sljedećim kriterijima: prema pravom podrijetlu, prema vremenu preuzimanja, prema stupnju prilagođenosti te statusu njemačke posuđenice $\mathrm{u}$ hrvatskome standardnom jeziku. $U$ ovome se radu pojam „germanizam“ koristio u najširem značenju, tj. za svaku posuđenicu koja je došla posrednim ili neposrednim putem s njemačkoga govornog područja u hrvatski jezik i koja je s vremenom doživjela proces prilagodbe da bi se mogla integrirati u sustav hrvatskoga jezika.

Ispitani germanizmi rimovanih dvostiha potvrđeni su u svim područjima svakodnevnoga života poput trgovine, poljoprivrede, kulinarstva, obrta, kulture oblačenja, običajima. U stihovima su pronađeni i neki pejorativni izrazi te nekolicina slikovitih pridjeva koji opisuju ljudske osobine. Morfološki prilagođeni glagoli također su zabilježeni. Dakle, ti 
nam germanizmi pokazuju u kolikoj su mjeri dvije kulture i dva jezika bili međusobno prožeti te na koji su način posuđenice utjecale na jezik primalac.

Kao i turcizmi, i germanizmi su promatrani u okviru određenih semantičkih polja podijeljenih na područja koja obuhvaćaju: a) leksik kulinarstva, b) leksik odjevnih predmeta, ukrasa, nakita i tekstila, c) leksik kućnoga inventara i imenovanja prostora i okućnice, d) leksik botanike i vrtlarstva, poljoprivrede, obrtništva i vojništva, e) leksik pogrdnih imena, nadimaka i osobina te f) leksik međuljudskih odnosa i osjećaja.

S obzirom na vrijeme provedeno u austrijskome carstvu (od 1527. do 1918.) živeći u zajedništvu s doseljenim stanovništvom, prvenstveno trgovcima i obrtnicima i potrebu korištenja njemačkoga jezika u svrhu pravnih, političkih, društvenih, gospodarskih i vojničkih potreba, ne čudi činjenica da germanizmi prodiru u svih šest semantičkih polja podijeljenih po navedenim pojedinim područjima. Dakle, to je dokaz snažnoga utjecaja njemačke kulture na život i rad starosjedilačkoga stanovništva.

Međutim, kada govorimo o prodoru germanizama u hrvatski jezik, potrebno je napomenuti kako su se te posuđenice zadržale samo u domeni razgovornoga jezika i u dijalektima. Babić (2004: 207) tumači da „u svoj književni jezik nismo primili ni četrdeset germanizama“, a to objašnjava time ,što smo od njemačkoga jezika bili ugroženi, posebno u 19. stoljeću, i da spasimo svoje hrvatstvo, razvili smo jaku nacionalnu svijest i postavili tako gusti filtar prema njemačkome jeziku da je propustio samo pokoji čisti germanizam.“

Slijedom rečenoga i s obzirom na broj analiziranih germanizama utvrđeno je kako se najveći broj njih odnosi na leksik odjevnih predmeta, ukrasa, nakita što dokazuju i danas brojne zadržane posuđenice za pojedine odjevne elemente narodne nošnje, modne detalje i ukrase.

Kao i turcizmi i brojni su germanizmi pronašli svoje mjesto u leksiku poljoprivrede, naročito vojništva i obrta. Razumljivo s obzirom na političku situaciju i društveno-povijesni kontekst unutar kojeg je doseljeno i starosjedilačko stanovništvo živjelo i surađivalo gotovo 400 godina. S druge pak strane, germanizmi nisu pronađeni u vrtlarstvu, a u cijelom su kontekstu botanike zabilježene samo dvije posuđenice. Domicilno je stanovništvo i svoj životni prostor oplemenilo brojnim predmetima koji pripadaju kućnom inventaru i okućnici.

Najmanji broj zabilježenih germanizama uočeno je u leksiku kulinarstva te u leksiku međuljudskih odnosa i osjećaja dok je leksik pogrdnih imena, nadimaka i osobina neznatan. 
Oblici koje su germanizmi i turcizmi poprimali primarnom i sekundarnom prilagodbom u hrvatskome jeziku mogu se objasniti različitim čimbenicima; vremenom njihova usvajanja, karakteristikama govornika jezika u kontaktu, njihovom pripadnošću određenome kulturnodruštvenom sloju, stupnjem obrazovanja, zemljopisnim podrijetlom i političkom situacijom.

Treba razlučiti kako je postojala velika razlika u odnosu tadašnjih govornika prema posuđenicama njemačkoga i tursko-osmanskog jezika koje se mogu vidjeti i pratiti kroz povijesno-društvene prilike. Dok je osmanlijski svijet pokorenoj zemlji i žiteljstvu nametao svoj jezik, kulturu i običaje izrazito napadačkom politikom, politikom osvajanja i podjarmljivanja te je prihvaćanje istoga bio znak nešto ugodnijega života i potrebe, njemačke su posuđenice ulazile u naš jezik ,,manje nasilnim“ putem, putem reforme školstva i obećanjem mogućnosti daljnjega obrazovanja i napredovanja u društvu općenito. Utjecaj je navedenih posuđenica na jezik deseteračkih dvostiha u Slavoniji, Baranji i Srijemu golem jer one i danas u njima dominiraju, a izbacivanje istih i njihova zamjena novonastalima ili domaćim riječima rezultirala bi mijenjanjem značenja teksta, ogoljivanjem i osiromašivanjem stupnja originalnosti i izvornosti pjevnoga sadržaja. To se vidi i u navedenim primjerima ${ }^{255}$ :

Misečina uprla u granje, Jaoj moja pregačo i cvikle, Kad zamotam 'nu žutu maramu, lipa večer za ašikovanje. srce boli, što ne vidi dike. razveselim moje dike mamu.

\footnotetext{
${ }^{255}$ Ako se riječ ašikovanje zamijeni riječju voljenje, milovanje, ljubavno razgovaranje (Klaić: 2002) gubi se puno od originalnosti teksta te se otvara prostor brojnim konotacijama. Izrazu cvikle je u hrvatskom jeziku ekvivalent umetak. Njegovom zamjenom narušava se rima. Zamjena turcizma marama riječju rubac ili ubrus nemoguća je jer je marama naziv određenog ženskog odjevnog predmeta kojim se pokriva glava. Riječ ubrus u sebi nosi asocijaciju na dio stolnog pribora koji služi za brisanje usta ili zaštitu odjeće uz jelo.
} 


\section{LITERATURA}

\subsection{Izvori}

1. Lukić, Luka. Pjesmarica. IEF rkp N84 (1903. - 1919.).

2. Lukić, Luka. Narodne popijevke iz okolice Slavonskog Broda, sv. 1-6. IEF rkp N124 (1915. - 1950.).

3. Lukić, Luka. Hrvatske pučke popijevke iz Slavonskog Broda. IEF rkp N4 (1919a).

4. Lukić, Luka. Popijevke iz okolice Slavonskog Broda /originalni zapisi/. IEF rkp N42 (1919b).

5. Lukić, Luka. Narodne popijevke iz okolice Slavonskog Broda (s notnim zapisima) OE HAZU NZ 5a, b, c, d, e, f, g (1890. - 1955.).

6. Lukić, Luka. Opis sela Klakarja. Po Radićevoj Osnovi I., II., III., IV. dio. OE HAZU SZ 128a (1911. - 1912.).

7. Lukić, Luka. Oprisavačke priskočnice, rukopis čuvan u Muzeju Brodskog Posavlja.

8. Lukić, Luka. Kaniške priskočnice, rukopis čuvan u Muzeju Brodskog Posavlja.

9. Lukić, Luka. Varoške pjesme, rukopis čuvan u Muzeju Brodskog Posavlja.

10. Lukić, Luka. Priskočnice što se govore u kolu, kraće pjesme iz Varoša, rukopis čuvan u Muzeju Brodskog Posavlja.

11. Lukić, Luka. Stare pjesme iz Varoša, rukopis čuvan u Muzeju Brodskog Posavlja.

12. Lukić, Luka. Priskočnice iz kola, rukopis čuvan u Muzeju Brodskog Posavlja.

13. Janković, Slavko (1967). Šokačke pismice I. Dvostihovi-deseterci 1-2000. Napjevi 150, Vinkovci: Matica hrvatska.

14. Janković, Slavko (1970). Šokačke pismice II. Dvostihovi - deseterci 2001-4230. Napjevi 51-100, Vinkovci: Matica hrvatska.

15. Janković, Slavko (1974). Šokačke pismice III. Dvostihovi - deseterci 4231-6145. Napjevi, Vinkovci: Matica hrvatska.

\subsection{Leksikografski izvori}

1. Anić, Vladimir (2003). Veliki rječnik hrvatskoga jezika, Zagreb: Novi Liber.

2. Bagić, Krešimir (2012). Rječnik stilskih figura, Zagreb: Školska knjiga.

3. Baskakov, A. Nikolaevich i dr. (1977). Turecko-russkij slovar, Moskva: Russkiy Yazyk. 
4. Bezić, Jerko (1974). Muzička enciklopedija, Zagreb: Jugoslavenski leksikografski zavod.

5. Brodnjak, Vladimir (1992). Rječnik razlika između hrvatskoga i srpskoga jezika, Zagreb: Školska knjiga.

6. Brozović Rončević, Dunja (glav. ur.) (2012). Školski rječnik hrvatskoga jezika, Zagreb: Institut za hrvatski jezik i jezikoslovlje - Školska knjiga.

7. Gortan-Premk, Darinka (2002). Semantičko-derivacioni rečnik srpskoga jezika, Deskriptivna leksikografija standardnog jezika i njene teorijske osnove, Novi Sad Beograd.

8. Group of authors (2010). Turkish Concise Dictionary, New York - Munich - Singapore: Berlitz Publishing.

9. Hansen-Kokoruš, Renate i dr. (2005). Deutsch-kroatisches universalwörterbuch, Zagreb: Nakladni zavod Globus i Institut za hrvatski jezik i jezikoslovlje.

10. Işıker, Mehmet (2010). Temeljni tursko-hrvatski rječnik, Zagreb: Ibis grafika d.o.o.

11. Jakšić, Martin (2003). Divanimo po slavonski, Zagreb: Pergamena.

12. Jakšić, Martin (2015). Rječnik govora slavonskih, baranjskih i srijemskih, Zagreb: Dominović.

13. Klaić, Bratoljub (2002). Rječnik stranih riječi, Zagreb: Nakladni zavod Matice hrvatske.

14. Menac, Antica, Fink Arsovski, Željka, Venturin, Radomir (2014). Hrvatski frazeološki rječnik, Naklada Ljevak: Zagreb.

15. Nosić, Milan (2005). Rječnik posuđenica iz turskoga jezika, Rijeka: Maveda.

16. Poljoprivredna enciklopedija (1967). Zagreb: Jugoslavenska akademija znanosti i umjetnosti.

17. Simeon, Rikard (1969). Enciklopedijski rječnik lingvističkih naziva na osam jezika (hrvatsko-srpski, latinski, ruski, njemački, engleski, francuski, talijanski), Zagreb: Matica hrvatska.

18. Skok, Petar (1971 - 1973). Etimologijski rječnik hrvatskoga ili srpskoga jezika, Zagreb: Jugoslavenska akademija znanosti i umjetnosti.

19. Skupina autora (2002). Hrvatski enciklopedijski rječnik, Zagreb: Novi Liber.

20. Steuerwald, Karl (1972). Türkisch-deutsches Wörterbuch, Wiesbaden: Harrassowitz.

21. Šarić, Ljiljana, Wiebke Wittschen (2008). Rječnik sinonima hrvatskoga jezika, Zagreb: Jesenski i Turk.

22. Wolf, Ivan (2006). Rječnik njemačko-hrvatski/hrvatsko-njemački s gramatikom, Split: Marjan tisak. 


\subsection{Literatura}

1. Andrić, Marta (2003). Turcizmi u seoskom govoru Slavonije, Migracijske i etničke teme 19 (1): $15-25$.

2. Babić, Stjepan (1966). Jezik, Zagreb: Školska knjiga.

3. Babić, Stjepan (1990). Hrvatska jezikoslovna čitanka, Zagreb: Globus.

4. Babić, Stjepan (1990). Njemačke posuđenice u hrvatskom jeziku, Hrvatska jezikoslovna čitanka. Zagreb: Globus: 214-224.

5. Babić, Stjepan (2004). Hrvanja hrvatskoga: hrvatski u koštacu sa srpskim i u klinču s engleskim, Zagreb: Školska knjiga.

6. Bakota, Lidija (2010). Tumačenje nepoznatih riječi u razrednome kontekstu, Metodika $11(2), 206-224$.

7. Barić, Eugenija i dr. (1999). Hrvatski jezični savjetnik, Zagreb: Institut za hrvatski jezik i jezikoslovlje.

8. Barić, Eugenija i dr. (2005). Hrvatska gramatika, Zagreb: Školska knjiga.

9. Barišić, Ana Tereza i Makaj, Zorana (2015). Bećarac - izgubljen u prijevodu, Riječ na granici kultura: Zbornik radova sa Pete konferencije Instituta za strane jezike. (ur. Vesna Bratić i Milica Vuković), Podgorica: Institut za strane jezike, 153-163.

10. Barišić, Ana Tereza (2016a). Književni prikaz Prvoga svjetskog rata u kontekstu bećaraca, Pannoniana: Časopis za humanističke znanosti 1, 1, 117-134.

11. Barišić, Ana Tereza (2016b). Utjecaj posuđenica na jezik pismica Slavonije, Baranje i Srijema, Šesti hrvatski slavistički kongres: Zbornik radova sa znanstvenoga skupa s međunarodnim sudjelovanjem održanoga u Vukovaru i Vinkovcima od 10. do 13. rujna 2014. [ur. Stipe Botica, Davor Nikolić, Josipa Tomašić i Ivana Vidović-Bolt], Zagreb: Hrvatsko filološko društvo - Hrvatski slavistički odbor, 89-100.

12. Binder, Theo (2006). Njemačke posuđenice u hrvatskom govoru Osijeka. Zagreb: FF press.

13. Blaževac-Pajkov, Mato (2016). Luka Lukić - učitelj, etnograf i melograf u Klakaru, Zagreb - Klakar: Hrvatska akademija znanosti i umjetnosti - Općina Klakar.

14. Boroević, Nikola (1840) Pitanje rodoljubca, Danica ilirska 6/1840, br. 29: 113-116.

15. Botica, Stipe (1995). Hrvatska usmenoknjiževna čitanka, Zagreb: Školska knjiga.

16. Botica, Stipe (1996). Usmene lirske pjesme, Zagreb: Matica hrvatska.

17. Botica, Stipe (2013). Povijest hrvatske usmene književnosti, Zagreb: Školska knjiga. 
18. Ceribašić, Naila (2013). Bećarac, tradicijska glazba istočne Hrvatske, Blaga Hrvatske - neprocjenjiva prirodna i kulturna baština, Zagreb: Mozaik knjiga.

19. Cruse, D. Alan (1986). Lexical semantics, Cambridge: Cambridge University Press, Cambridge.

20. Cruse, Alla (2007). A Glossary of Semantics and Pragmatics, Edinburgh University Press.

21. Čaušević, Ekrem (1996). Gramatika suvremenoga turskoga jezika, Zagreb: Hrvatska sveučilišna naklada.

22. Čubrić, Marina (2005). Učimo hrvatski, 4. Zagreb: Školska knjiga.

23. Čunko, Tatjana (2017). „U boj, u boj!“ - uz 75 godina djelovanja Zbora hrvatske radiotelevizije - prve četiri sezone (1941 - 1945), ARMUD6 48/1, 95-117.

24. Ćoruša, Vedrana (2012). Sinonimija i sinonimičnost u hrvatskome jeziku, završni rad. Osijek: Filozofski fakultet Sveučilišta Josipa Jurja Strossmayera.

25. Dabo-Denegri, Ljuba (1998). Jezično posuđivanje: tipologija leksičkih posuđenica (anglicizmi u francuskom jeziku), Filologija 30-31: 439-450.

26. Dabo-Denegri, Ljuba (2007). Hrvatsko-francuski jezični dodiri, Zagreb: Nakladni zavod Globus.

27. Despot, Loretana (2006). Jezične osobitosti baranjskih govora, Šokačka rič 3: Zbornik radova Znanstvenog skupa "Slavonski dijalekt" održanoga u Vinkovcima 11. 12.11.2005. (ur. Anica Bilić), Vinkovci: Zajednica kulturno-umjetničkih djelatnosti Vukovarsko-srijemske županije, 29-37.

28. Dešić, Milorad (1982). Polisemija i homonimija u rečnicima savremenog srpskohrvatskog jezika, Naš jezik 24 (4-5): 231-241.

29. Dirim, Inci (2005). Stolpersteine der deutschen Sprache und das Türkische, Teacher Education for the Support of Second Language Acquisition.

30. Dobričević, Tatjana (2000). O homonimiji u hrvatskom jeziku, Radovi Leksikografskoga zavoda Miroslav Krleža, 9, 133-146.

31. Dragičević, Dragica (2005). Hrvatski u dodiru s njemačkim jezikom u: Sočanac, Lelija, Žagar-Szentesi, Orsoyla, Dragičević, Dragica, Dabo-Denegri, Ljuba, Menac Antica i Hoyt-Nikolić, Anja (2005). Hrvatski jezik u dodiru s europskim jezicima, Zagreb: Nakladni zavod Globus.

32. Dragičević, Rajna (2007). Leksikologija srpskoga jezika, Beograd: Zavod za udžbenike.

33. Ferić, Mihael (2003). Zasvirajte tambure 2, Vinkovci: Kulturni centar Gatalinka. 
34. Filipović, Milenko (1970). Orijentalna komponenta u narodnoj kulturi Južnih Slavena, Prilozi za orijentalnu filologiju, 1966-67, XVI-XVII, 101-116.

35. Filipović, Rudolf (1979). Transmorfemizacija - najčešći oblik supstitucije na morfološkom nivou, Filologija 9: 177-183.

36. Filipović, Rudolf (1986). Teorija jezika u kontaktu, Zagreb: Školska knjiga.

37. Fink-Arsovski, Željka (2002). Poredbena frazeologija: pogled izvana i iznutra, Zagreb: FF press.

38. Gajger-Krajnović, Martina (1991). Etnomuzikološki rad Luke Lukića (1875. - 1956.) uz usporedbu sa snimcima vokalne folklorne građe u okolici Slavonskog Broda 80-tih godina našega stoljeća, diplomski rad, Muzička akademija u Zagrebu.

39. Geiger, Vladimir, Kučera, Mario (1995). Iz povijesti Nijemaca na hrvatskim prostorima, VDH Jahrbuch, Znanstveni skup Nijemci i Austrijanci u hrvatskom kulturnom krugu: 85-92.

40. Gilliéron, Jules (1915). Pathologie et thérapeutique verbales, Neuveville.

41. Giro, Pjer (1975). Semiologija, Beograd: Beogradski izdavačko-grafički zavod.

42. Glibanović-Vajzović, Hanka (1986). O turcizmima u srpskohrvatskom jeziku sa sociolingvističkog stajališta, Književni jezik. 15, 2, 141-147.

43. Goldstein, Ivo (2003). Hrvatska povijest, Zagreb: Biblioteka Jutarnjega lista.

44. Gološ, Enisa (2017). Neki oblici sinonimije u djelu Hamze Hume, DHS 3, 47-58.

45. Gortan-Premk, Darinka (1997). Polisemija i organizacija leksičkog sistema u srpskome jeziku, Beograd: Institut za srpski jezik SANU.

46. Gortan-Premk, Darinka (2004). Polisemija i organizacija leksičkog sistema u srpskome jeziku, Beograd: Zavod za udžbenike i nastavna sredstva.

47. Grabčanović, Merima (2019). Sinonimi u romanu Masümiyet Müzesi Orhana Pamuka, DHS 2 (8), 135-152.

48. Grgurovac, Martin (2005). Slavonske pismice, Vinkovci: SN Privlačica Vinkovci.

49. Grgurovac, Martin, Živković, Pavo (2007). Veliki i poznati Šokci, Vinkovci: Biblioteka Dukat.

50. Hadžihusejnović-Valašek, Miroslava (1981). Pregled rezultata dosadašnjih etnomuzikoloških istraživanja i melografiranja u Slavoniji, Anali Centra Jugoslavenske akademije, Osijek, 77-142.

51. Haspelmath, Martin (2009). Lexical borrowing: Concepts and issues, Loanwords in the World's Languages: a comparative handbook. [ed. Martin Haspelmath and Uri Tadmor]. Berlin: De Gruyter Mouton. 
52. Haugen, Einar (1950r). The analysis of Linguistic Borrowing, Language 26: 210-231.

53. Haugen, Einar (1956). Bilingualism in the Americas: a Bibliography and Research Guide, University of Alabama Press.

54. Hope, Thomas Edward (1960). The Analysis of Semantic Borrowing, Essays Presented to C. M. Girdlestone University of Durham. King's College. Newcastle upon Tyne, 125141.

55. Horvat, Stjepan (1979). Leksikon zagonetaša Jugoslavije, Bjelovar: Enigmatsko udruženje „Č́vor“.

56. Horga, Damir, Liker, Marko (2016). Artikulacijska fonetika: anatomija i fiziologija izgovora, Zagreb: IBIS grafika.

57. Hudeček, Lana, Mihaljević, Milica (1996). Višeznačni odnosi u nazivlju i njihova leksikografska obrada, Rasprave Instituta za hrvatski jezik i jezikoslovlje, 22, 51-62.

58. Hudeček, Lana, Mihaljević, Milica (1997). Višeznačni odnosi u nazivlju i njihova leksikografska obradba, Rasprave Instituta za hrvatski jezik i jezikoslovlje 22: 51-62.

59. Hudeček, Lana, Mihaljević, Milica (2008). Veznička sinonimija i antonimija u hrvatskoj leksikografiji, Rasprave Instituta za hrvatski jezik i jezikoslovlje 34.

60. Hudeček, Lana, Mihaljević, Milica (2009). Homonimija kao leksikografski problem, Rasprave Instituta za hrvatski jezik i jezikoslovlje, 35, 159-186.

61. Ivanetić, Nada (2000). Germanizmi u jednom čakavskom govoru, Zbornik radova Riječki filološki dani 3: 159-170.

62. Jelaska, Zrinka (2007). Načela određivanja sinonima, Filološke studije 5, vol. 2, Skopje - Perm - Ljubljana - Zagreb: Sveučilište Sv. Ćirila i Metoda, Skoplje 209-220.

63. Jelaska, Zrinka (2004). Fonološki opisi hrvatskoga jezika; glasovi, slogovi, naglasci, Zagreb: Hrvatska sveučilišna naknada.

64. Jozić, Željko (2010) Posavski govori oko Slavonskoga Broda, Prinosi hrvatskoj dijalektnoj fonologiji, Split - Zagreb, 225-281.

65. Katalinić, Kristina (2013). Hungarizmi u hrvatskom književnom jeziku od kraja 16. do polovice 18. stoljeća, doktorska disertacija, Budapest.

66. Kordić, Ljubica (2006). Refleksija socijalno-političkih promjena na govor vukovarskog kraja, Zbornik Jezik i identiteti. [ur. Jagoda Granićc, 279-291. Zagreb; Split: Hrvatsko društvo za primijenjenu lingvistiku.

67. Krongauz, Maksim Anisimovič (2001). Semantika, Moskva: Rossijskij gosudarstvennyj gumanitarnyj universitet. 
68. Krpan, Stjepan (1994). Zavičajnici: portreti malo spominjanih, prešućivanih $i$ zaboravljanih, Slavonski Brod: Matica hrvatska.

69. Kuhač, Franjo Ksaver $(1878,1879,1880,1881,1941)$ Južno-slovjenske narodne popievke, Zagreb: Tiskara i litografija C. Albrechta.

70. Lisac, Josip (2003) Hrvatska dijalektologija 1., Hrvatski dijalekti i govori štokavskog narječja i hrvatski govori torlačkog narječja, Zagreb: Golden marketing - Tehnička knjiga.

71. Lisac, Josip (2003a) Slavonski dijalekt: između autohtonosti i utjecaja, Migracijske $i$ etničke teme, 19, I, 7-16.

72. Lukač, Karolina (2017). Rukopisna ostavština Luke Lukića u Muzeju Brodskog Posavlja, Informatica museologica 48, 192-195.

73. Lukić, Luka (1919). Varoš - narodni život i običaji, Zbornik za narodni život i običaje južnih Slavena, knj. 24. [ur. Dragutin Boranić], 32-238. Zagreb: Jugoslavenska akademija znanosti i umjetnosti.

74. Lukić, Luka (1924). Varoš - narodni život i običaji, Zbornik za narodni život i običaje južnih Slavena, knj. 25. svezak 2. [ur. Dragutin Boranić], 105-175. Zagreb: Jugoslavenska akademija znanosti i umjetnosti.

75. Lukić, Luka (1926). Varoš - narodni život i običaji, Zbornik za narodni život i običaje južnih Slavena, knj. 26. svezak 1. [ur. Dragutin Boranić], 102-138. Zagreb: Jugoslavenska akademija znanosti i umjetnosti.

76. Lukić, Luka (2016a). Opis sela Klakarja: graditeljstvo, pokućstvo, sprave i oruđa početkom 20. stoljeća, Zagreb - Klakar: Hrvatska akademija znanosti i umjetnosti i Općina Klakar.

77. Lukić, Luka (2016b). Opis sela Klakarja: pripovijetke i pjesme skupljane od sredine 19. do sredine 20 stoljeća, Zagreb - Klakar: Hrvatska akademija znanosti i umjetnosti i Općina Klakar.

78. Lyons, John (1981). Language and Linguistics: an introduction, Cambridge, Cambridge University Press.

79. Ljubičić, Maslina (2011). Posuđenice i lažni parovi: Hrvatski, talijanski i jezično posredovanje, Zagreb: FF press.

80. Maradin, Maša (2019). Polisemija i sinonimija u financijskoj terminologiji hrvatskoga jezika, doktorski rad, Sveučilište u Zadru.

81. Matasović, Ranko (2001). Jezična raznolikost svijeta, Zagreb: Matica hrvatska.

82. Mažuran, Ive (1998). Hrvati i Osmansko Carstvo, Zagreb: Golden marketing. 
83. Medić, Ivo (1975). Kleine deutsche Grammatik, Zagreb: Školska knjiga.

84. Meinhold, Gottfried i Stock, Eberhard (1980). Phonologie der deutschen Gegenwartssprache, Leipzig: WEB Bibliographisches Institut.

85. Melvinger, Jasna (1984). Leksikologija, Osijek: Pedagoški fakultet.

86. Menac, Antica (2007). Hrvatska frazeologija, Zagreb: Knjižara Zagreb.

87. Meštrović, Mirko, Virc, Zlatko (1974) Pogovor knjizi Šokačke pismice III, u: Janković, Slavko (1974). Šokačke pismice III., Vinkovci: Matica hrvatska, 141-142.

88. Mihaljević, Milica (2007). Problemi hrvatskoga računalnoga nazivlja (s jezikoslovnog motrišta), Studia lexicographica 1 (1), 61-79.

89. Mihaljević, Milica, Šarić, Ljiljana (1996). Metaforizacija kao terminološki postupak u engleskom i hrvatskom, Suvremena lingvistika 41-42: 437-451.

90. Milić, M. Mira (2013). Anglizmi kao sinonimi u srpskom jeziku, Doktorska disertacija, Filozofski fakultet u Novom Sadu.

91. Miloš, Irena (2016). Jezična napomena monografiji Opis sela Klakarja: pripovijetke $i$ pjesme skupljane od sredine 19. do sredine 20 stoljeća, u: Lukić, Luka (2016b). Opis sela Klakarja: pripovijetke i pjesme skupljane od sredine 19. do sredine 20 stoljeća, Zagreb - Klakar: Hrvatska akademija znanosti i umjetnosti i Općina Klakar, 41-42.

92. Moačanin, Fedor (1984). Vojna krajina do kantonskog uređenja 1787., Vojna krajina: povijesni pregled, historiografija, rasprave, [ur. Dragutin Pavličević], Zagreb: Sveučilišna naklada Liber, 23-44.

93. Moačanin, Fedor i Valentić, Mirko (1981). Vojna krajina u Hrvatskoj, Zagreb: Povijesni muzej Hrvatske.

94. Moačanin, Nenad (2001). Slavonija i Srijem u razdoblju osmanske vladavine, Slavonski Brod: Hrvatski institut za povijest, Podružnica za povijest Slavonije, Srijema i Baranje.

95. Murphy, M. Lynne (2003). Semantic relations and the lexicon, Cambridge: Cambridge University Press.

96. Musulin, Maša (2011). Grafem kao višeznačnica, Lahor, 12, 240-247.

97. Myers-Scotton, Carol (2002). Contact Linguistic: Bilinguan Encounters and Grammatical Outcomes, Oxford: University Press.

98. Nida, Eugene Albert (1975). Exploring Semantic Structures, München: Wilhelm Fink Verlag.

99. Nosetić, Petra (2013). Njemačko-turski jezični dodiri u Njemačkoj: jezičnobiografska i jezičnosistemska analiza, interdisciplinarni završni rad, Sveučilište u Zagrebu. 
100. Perić-Polonijo, Tanja i Vanić, Dunja (2016). Uvod monografiji Opis sela Klakarja: pripovijetke i pjesme skupljane od sredine 19. do sredine 20 stoljeća, u: Lukić, Luka (2016b). Opis sela Klakarja: pripovijetke i pjesme skupljane od sredine 19. do sredine 20 stoljeća, Zagreb - Klakar: Hrvatska akademija znanosti i umjetnosti i Općina Klakar, $7-40$.

101. Petrović, Bernardina (2004). Leksičke osobitosti mjesnih govora slavonskoga dijalekta u vinkovačkome kraju, Šokačka rič 1: Zbornik radova sa Znanstvenoga skupa Slavonski dijalekt $s$ posebnim naglaskom na lokalnim govorima vinkovačkoga $i$ županjskoga kraja održanoga u Vinkovcima 14. studenoga 2003. (ur. Anica Bilić), Vinkovci: Zajednica kulturno-umjetničkih djelatnosti Vukovarsko-srijemske županije, $65-81$.

102. Petrović, Bernardina (2005). Sinonimija i sinonimičnost u hrvatskome jeziku, Zagreb: Hrvatska sveučilišna naklada.

103. Piškorec, Velimir (2005). Germanizmi u govorima đurđevačke Podravine, Zagreb: FF Press.

104. Pon, Leonard (2009). Njemački leksik u nekim djelima slavonske književnosti, Šokačka rič 6: zbornik radova Znanstvenoga skupa Slavonski dijalekt (1845 - 190X), [ur. Anica Bilić], Vinkovci: Zajednica kulturno-umjetničkih djelatnosti Vukovarskosrijemske županije, 105-121.

105. Pranjković, Ivo (2002). Hrvatski i orijentalni jezici, Zbornik Zagrebačke slavističke škole 2001. [ur. Miljenko Jurković] Zagreb: Filozofski fakultet, FF press. 16-28.

106. Pranjković, Ivo (2007). Glavne sastavnice hrvatskoga jezičnoga identiteta, Jezik $i$ identiteti, Zbornik Hrvatskoga društva za primijenjenu lingvistiku, HDPL, Zagreb-Split, 487-496.

107. Prćić, Tvrtko (1997). Semantika i pragmatika reči, Novi Sad: Izdavačka knjižarnica Zorana Stojanovića.

108. Prćić, Tvrtko (2005). Engleski u srpskom, Novi Sad: Zmaj.

109. Radić, Antun (1897). Osnova za sabiranje i proučavanje građe o narodnom životu, Zbornik za narodni život i običaje Južnih Slavena, sv. II., (ur. Antun Radić), Zagreb: Jugoslavenska akademija znanosti i umjetnosti, 1-88.

110. Raffaelli, Ida (2007). Neka načela ustroja polisemnih leksema, Filologija 48: 135-172.

111. Raffaelli, Ida (2009). Značenje kroz vrijeme, Zagreb: Disput.

112. Raffaelli, Ida (2015). O značenju: Uvod u semantiku, Zagreb: Matica hrvatska.

113. Riđanović, Midhat (1998). Jezik i njegova struktura, Sarajevo: Šahinpašić. 
114. Rončević, Ivan (2013). Bećarac - dvostruko rimovani deseterac kao kulturni izričaj Istočne Hrvatske, diplomski rad, Beč: Univerzität Wien.

115. Rončević, Ivan (2019). Frazemi u tradicijskim deseteračkim dvostisima u Slavoniji. Slavofraz 2018: Frazeologija, učenje i poučavanje, Rijeka: Sveučilište u Rijeci, 293304.

116. Rosandić, Dragutin i Silić, Josip (1979). Osnove morfologije i morfostilistike hrvatskoga književnog jezika, Zagreb: Školska knjiga.

117. Samardžija, Marko (1989). Homonimi u hrvatskom književnom jeziku, Radovi Zavoda za slavensku filologiju, 24, str. 1-71.

118. Samardžija, Marko (1995). Leksikologija s poviješću hrvatskoga jezika u XX. Stoljeću, Zagreb: Školska knjiga.

119. Samardžija, Marko (1998). Hrvatski jezik 4, Zagreb: Školska knjiga.

120. Samardžija, Marko (2003). Hrvatski jezik IV. Udžbenik za 4. razred gimnazije, Zagreb: Školska knjiga.

121. Schwenk, Helga (2009). Sprachvergleich Türkisch-Deutsch für den pädagogischen Kontext.

122. Sekereš, Stjepan (1977). Govor Hrvata u južnoj Baranji, Hrvatski dijalektološki zbornik, Zagreb, 323-484.

123. Silić, Josip (1998). Leksik i norma, Radovi Zavoda za slavensku filologiju 32: 169175.

124. Sočanac, Lelija (2004). Hrvatsko-talijanski jezični dodiri, Zagreb: Nakladni zavod Globus.

125. Sočanac, Lelija, Žagar-Szentesi, Orsoyla, Dragičević, Dragica, Dabo-Denegri, Ljuba, Menac Antica i Hoyt-Nikolić, Anja (2005). Hrvatski jezik u dodiru s europskim jezicima, Zagreb: Nakladni zavod Globus.

126. Stojić, Aneta (2006). Semantička prilagodba nadregionalnih njemačkih posuđenica (na primjeru imenica), Fluminensia 18 (1): 53-63.

127. Stojić, Aneta (2008). Njemačke posuđenice i hrvatski ekvivalenti, Rasprave Instituta za hrvatski jezik i jezikoslovlje 34: 357-369.

128. Surdučki, Milan (1978). Srpskohrvatski i engleski u kontaktu, Novi Sad: Matica srpska.

129. Ščukanec, Aleksandra (2011). Njemačko-hrvatski jezični dodiri u Gradišću, doktorska disertacija, Sveučilište u Zagrebu.

130. Šipka, Danko (1990). Leksička homonimija, Sarajevo: Institut za jezik. 
131. Šipka, Danko (1998). Osnovi leksikologije i srodnih disciplina, Novi Sad: Matica srpska.

132. Širola, Božidar (1925). Znameniti i zaslužni Hrvati te pomena vrijedna lica u hrvatskoj povijesti od 925-1925., Zagreb: Odbor za izdavanje knjige „Zaslužni i znameniti Hrvati 925-1925“.

133. Šišić, Ferdo (2004). Povijest Hrvata, Zagreb: Marjan tisak.

134. Šivic-Dular, Alenka (1999). Lingvistička definicija vlastite imenice, Folia onomastica Croatica, 7, 281-293.

135. Štambuk, Anuska (2002). Hrvatske istovrijednice engleskih metafora u rječnicima elektroničkog nazivlja, Filologija 38-39: 227-237.

136. Štebih-Golub, Barbara (2010). Germanizmi u kajkavskome književnom jeziku. Zagreb: Institut za hrvatski jezik i jezikoslovlje.

137. Švagelj, Dionizije (1967). Predgovor knjizi Šokačke pismice I, u: Janković, Slavko (1967). Šokačke pismice I., Vinkovci: Matica hrvatska, 5-7.

138. Tafra, Branka (1982). Sinonimija, Leksikografija i leksikologija. [ur. Drago Ćupić], Beograd; Novi Sad: SANU, Matica srpska, Filološki fakultet Beograd, Filozofski fakultet Novi Sad. 297-300.

139. Tafra, Branka (1986). Razgraničavanje homonimije i polisemije: leksikološki i leksikografski problem, Filologija, 14, 381-393.

140. Tafra, Branka (1992). Crtice o Anićevu rječniku. Jezik 39 (4): 112-119.

141. Tafra, Branka (1995). Jezikoslovna razdvojba, Zagreb: Matica hrvatska.

142. Tafra, Branka (2003). Leksičke pogreške zbog sličnosti, Govor 20, 1-2: 431-448.

143. Tafra, Branka (2005). Od riječi do rječnika, Zagreb: Školska knjiga.

144. Tafra, Branka i Košutar, Petra (2009). Rječotvorni modeli u hrvatskom jeziku, Suvremena lingvistika, 67/1, 87-107.

145. Tafra, Branka (2014). Derivatem i leksem, Suvremena lingvistika, 40 (77), 77-90.

146. Tafra, Branka (2016). Homonimija - kroatistički kamen smutnje, Slavenska filologija, $144-154$.

147. Tafra, Branka (2017). Gramatička polisemija, Putevima reči. Zbornik radova u čast Darinki Gortan Premk. [ur. Rajna Dragičević], Beograd: Filološki fakultet Univerziteta u Beogradu. 563-575.

148. Talanga, Tomislav (1990). Germanizmi naši svagdašnji, Godišnjak OMH 8 (12): 129_ 162. 
149. Talanga, Tomislav (1996). Germanizmi u nas motivirani pučkom etimologijom, Godišnjak OMH 14: 127-138.

150. Talanga, Tomislav (2002). Pučka etimologija među nekim njemačkim posuđenicama, Jezikoslovlje, 3.1-2. 193-216.

151. Tamaro, Sandra (2008). Struktura rječničkoga članka u dijalektalnim čakavskim rječnicima: s posebnim osvrtom na problem homonimije i polisemije pri sastavljanju natuknica, Hrvatski dijalektološki zbornik 1a: 233-245.

152. Težak, Stjepko (1990). Hrvatski naš svagda(̌̌s)nji, Zagreb: Školske novine.

153. Težak, Stjepko i Babić, Stjepan (1994). Gramatika hrvatskoga jezika, Zagreb: Školska knjiga.

154. Todorov, Tzvetan (1978). Symbolisme et interprétation. Paris: Seuil. [1986. Simbolizam i tumačenje. Prev. J. Aćin. Novi Sad: Bratstvo-jedinstvo.]

155. Turk, Marija (1992). Fonologija hrvatskoga jezika (raspodjela fonema), Izdavački centar Rijeka i Tiskara Varaždin.

156. Ullmann, Stephen (1962). Semantics: An introduction to the science of meaning, Oxford: Basil Blackwell \& Mott.

157. Užarević, Josip (2009). Poetika bećarca, Šokačka rič 7, [ur. Anica Bilić], Vinkovci: Zajednica kulturno-umjetničkih djelatnosti Vukovarsko-srijemske županije, 111-139.

158. Vajzović, Hanka (1999). Orijentalizmi u književnom djelu: lingvistička analiza, Sarajevo: Institut za jezik u Sarajevu - Orijentalni institut u Sarajevu.

159. Vuković, Marinko (2011). Pogled na međuodnos baštine, kulture i identiteta, Arhivski vjesnik 54, 97-113.

160. Vuković, Marinko; Miloš, Irena (2015). Etnolingvistički pogled na Klakar početkom 20. stoljeća, Fluminensia, 27 (1), 71-85.

161. Zgusta, Ladislav (1991). Priručnik leksikografije, Sarajevo: Zavod za udžbenike i nastavna sredstva.

162. Žepić, Stanko (1991). Grundbegriffe der Phonologie und ein Vergleich der phonologischen Systeme des Deutschen und Kroatischen, Serbokroatisch-deutsche Kontrastivstudien. Zagreb: Zavod za lingvistiku Filozofskog fakulteta Sveučilišta u Zagrebu.

163. Žepić, Stanko (1996). Austrijski njemački u Hrvatskoj, Đurđevački zbornik: 309-319.

164. Žganec, Vinko (1967). Osvrt na Šokačke pismice I, Narodna umjetnost, 5-6, 613-614. 
165. Živković, Pavo (1996). Etnička i vjerska povijest Bosne, Slavonije i Srijema do konca XVII. stoljeća:(dolazak, razvoj $i$ nestajanje Hrvata katolika na tim prostorima), Sarajevo; Mostar: HKD Napredak.

166. Weinreich, Uriel (1953). Languages in contact: finding and problems, New York: Linguistic Circle.

\subsection{Sekundarna literatura}

1. Aksoy, Nuran (2004). Sprachkontrastive Darstellung Deutsch-Türkisch, Nordestedt: Grin Verlag.

2. Auer, Peter (2003). Türkenslang. Ein jugendsprachliches Ethnolekt des Deutschen und seine Transformation, Sprachewerb und Lebensalter, [ur. Häckl Buhofer], Tübingen: Francke, 255-264.

3. Babić, Stjepan (1977-1978). Mješovite tvorenice, Jezik 25 (5): 129-138.

4. Belaj, Vitomir (1991). Turski (orijentalni) elementi kod kršćanskog stanovništva Slavonije, Znanstveni sabor Slavonije i Baranje: zbornik radova, [ur. Dušan Čalić i Đuro Berber], Osijek: Jugoslavenska akademija znanosti i umjetnosti, 239-247.

5. Beljkašić, Ljiljana (1962). Orijentalni elementi u nošnjama balkanskih Slovena, Etnološki pregled 4: 98-103.

6. Benveniste, Émile (1966). Problèmes de linguistique générale I, Paris: Gallimard.

7. Coseriu, Eugenio (2000). Structural semantics and „cognitive“ semantics. Logos and Language 1 (1), 19-42.

8. Franceschini, Rita (2002). Sprachbiographien: Erzählungen über Mehrsprachigkeit und deren Erkenntnisinteresse für die Spracherwerbsforschung und die Neurobiologie der mehrsprachigkeit, Vereinigung für angewandte Linguistik in der Schweiz 76: 19-33.

9. Gavazzi, Milovan (1938). Problem karakterističnoga razmještaja nekih etnografskih elemenata na Balkanu, Sbornik na IV. Kongres na slavjanskita geografi i etnografi v Sofija: 231-236.

10. Krpan, Tomislav (1996). Bećarski zbornik I, Vinkovci: SN Privlačica Vinkovci.

11. Krpan, Tomislav (1999). Bećarski zbornik II, Vinkovci: SN Privlačica Vinkovci.

12. Lánstyák, István (2006). A kölcsönszavak rendszerezéséröl u: Lánstyák, István (2006). Nyelvből nyelvbe, Tanulmányok a szókölcsönzésröl, kódváltásról és forditásról, Pozsony: Kalligram Könyvkiadó, 15-57. 
13. Lukić, Luka (1923). O pučkom pjevanju u Slavoniji, Sveta Cecilija 17 (3-6): 73-74, 103-107, 137-138, 176-179.

14. Lukić, Luka (1928). Stare svatovske popijevke iz Varoša kod Broda na Savi, Sveta Cecilija 12 (1): 15-19.

15. Meisel, Jürgen M. (1977). The Language of Foreign Workers in Germany, Deutsch im Kontakt mit anderen Sprachen, [ur. Carol Monoly, Helmut Zobl, Wilfried Stöting], Kronberg/Ts.: Scriptor, 184-213.

16. Milković, Alen. (2010). Normiranje neologizama u hrvatskome jeziku, doktorska disertacija. Zagreb: Sveučilište u Zagrebu.

17. Neuland, Eva (2008). Jugendsprache, Tübingen: Narr Francke.

18. Petrović, Bernardina, Petranović, Petra. (2013). Turcizmi u djelima triju požeških pisaca. Lingua Montenegrina: časopis za jezikoslovna, književna i kulturna pitanja, 6 (11): $15-40$.

19. Piškorec, Velimir (2007). Narativni identitet u jezičnobiografskim intervjuima, Jezik $i$ identiteti, [ur. Jagoda Granić], Zagreb-Split: Hrvatsko društvo za primijenjenu lingvistiku, 457-467.

20. Piškorec, Velimir, Zelić, Marina (2006). Jezičnobiografski aspekti usvajanja njemačkog u izbjeglištvu, Strani jezici 35 (3): 277-290.

21. Riehl, Claudia Maria (2005). Sprachkontaktforschung: eine Einführung, Tübingen: Gunter Narr.

22. Schmaus, Alois (1961). Gramatički rod turskih imenica u južnoslavenskim jezicima, Zbornik za filologiju i lingvistiku 4/5, 300-308.

23. Sikirić, Šakić (1970). Prilog proučavanju turcizama, Prilozi za orijentalnu filologiju. Sarajevo, 342-368.

24. Škaljić, Abdulah (1966). Turcizmi u srpskohrvatskom jeziku, Sarajevo: Svjetlost.

25. Škaljić, Abdulah (2014). Turcizmi u našem jeziku, Sarajevo: Karika.

26. Štebih-Golub, Barbara (2008). Morfološka adaptacija posuđenica, Suvremena lingvistika 66 (2): 243-259.

27. Težak, Stjepko, Babić, Stjepan (1973). Pregled gramatike hrvatskoga književnoga jezika, Zagreb: Školska knjiga.

28. Toldi, Zvonimir (2013). Sve je cure Mile vezetiro!, Slavonski Brod: Folklorni ansambl Broda.

29. Ullmann, Stephen (1969). Précis de sémantique française, Berne: A. Francke. 
30. Ullmann, Stephen (1983). Semantics: An Introduction to the Science of Meaning, Oxford: B. Blackwell.

31. Valentić, Mirko (1990). Turski ratovi i hrvatska dijaspora u XVI. Stoljeću, Senjski zbornik 17: 45-60.

32. Vasić, Milan (1962). Etnička kretanja u Bosanskoj krajini u XVI. Vijeku, Godišnjak Društva istoričara Bosne i Hercegovine XIII, 233-249.

33. Vukomanović, Slavko (1979). Jezični kontakti u sinhronoj i dijahronoj perspektivi, Književnost i jezik 26 (2-3): 309-323. 


\section{PRILOZI}

\subsection{Popis tablica}

Tablica 1. Podjela deseteraca

Tablica 2. Prikaz leksema deseteračkih dvostiha u različitim govorima

Tablica 3. Homonimi i njihova kategorizacija u rječnicima

Tablica 4. Homoforme i njezina kategorizacija u rječnicima

Tablica 5. Homografi i njihova kategorizacija u rječnicima

Tablica 6. Homofoni i njihova kategorizacija u rječnicima

Tablica 7. Popis polisemnih leksema u deseteračkim dvostisima

Tablica 8. Fonološki sustav turskoga, hrvatskoga i njemačkoga jezika

Tablica 9. Prikaz turske abecede

Tablica 10. Prikaz njemačke abecede

Tablica 11. Prikaz konsonantskoga sustava hrvatskoga jezika

Tablica 12. Prikaz konsonantskoga sustava njemačkoga jezika

Tablica 13. Prikaz konsonantskoga sustava turskoga jezika

Tablica 14. Prikaz vokala u hrvatskome jeziku

Tablica 15. Prikaz vokala u hrvatskome jeziku

Tablica 16. Prikaz vokala u njemačkome jeziku

Tablica 17. Prikaz vokala u turskome jeziku

Tablica 18. Prikaz potpune transfonemizacije fonema jezika u kontaktu

Tablica 19. Prikaz kompromisne transfonemizacije fonema jezika u kontaktu

Tablica 20. Prikaz slobodne transfonemizacije fonema jezika u kontaktu

Tablica 21. Prikaz nulte transmorfemizacije morfema jezika u kontaktu

Tablica 22. Prikaz kompromisne transmorfemizacije morfema jezika u kontaktu

Tablica 23. Prikaz potpune transmorfemizacije morfema jezika u kontaktu

Tablica 24. Prikaz posuđenica u procesu nulte semantičke ekstenzije

Tablica 25. Prikaz posuđenica u procesu suženja broja značenja

Tablica 26. Prikaz posuđenica u procesu suženja polja značenja

Tablica 27. Prikaz posuđenica u procesu proširenja polja značenja

Tablica 28. Prikaz posuđenica u procesu proširenja broja značenja

Tablica 29. Prikaz posuđenica kao rezultat djelovanja elipse na jezik u kontaktu 


\subsection{Popis slika}

Slika 1. Prikaz podudarnih stihova

Slika 2. Udio podudarnih Lukićevih stihova u Jankovićevim zbirkama

Slika 3. Podudarni dio Lukićeve građe

Slika 4. Preslika zapisa Lukićevih stihova 


\section{ŽIVOTOPIS}

Ana Tereza Želinski (rođ. Barišić) rođena je 25. listopada 1983. u Slavonskome Brodu. Osnovnu je školu završila u Vranovcima, a Opću gimnaziju Matije Mesića u Slavonskome Brodu 2012. Na Filozofskome fakultetu Sveučilišta Josipa Jurja Strossmayera u Osijeku diplomirala je 2008. povijest i hrvatski jezik i književnost. Nakon završetka studija povijesti i hrvatskoga jezika i književnosti radila je kao nastavnica hrvatskoga jezika u Ekonomskobirotehničkoj školi Slavonski Brod do prosinca 2012. Od 2008. zaposlena je u Osnovnoj školi Vjekoslava Klaića u Garčinu gdje predaje hrvatski jezik, a od 15. listopada 2015. napreduje u zvanje učitelja mentora.

Poslijediplomski doktorski studij kroatistike upisala je u studenome 2010. Sudjelovala je izlaganjima na više znanstvenih i stručnih skupova u inozemstvu (Peta međunarodna konferencija Instituta za strane jezike ICIFL5 i Društva za primijenjenu lingvistiku Crne Gore Riječ na granici kultura 2014. u Podgorici, Crna Gora, 4th International Conference on Foreign Language Teaching and Apllied Linguistics and International Forum on Cognitive Linguistics Teaching, Acquiring and Applying Intercultural Linguistic Competence, International Burch University 2014. u Sarajevu, Bosna i Hercegovina, 5th International Conference on Foreign Language Teaching and Apllied Linguistics and International Forum on Slavic Studies Language Assessment for Multilingualism: Promoting Linguistic Diversity and Intercultural Communication, International Burch University 2015. u Sarajevu, Bosna i Hercegovina, Drugi bosanskohercegovački slavistički kongres 2015. u Sarajevu, Bosna i Hercegovina) i na nekoliko domaćih znanstvenih skupova u Hrvatskoj, među kojima su i oni s međunarodnim sudjelovanjem (Šesti hrvatski slavistički kongres 2014. u Vukovaru i Vinkovcima, Međunarodna studentska konferencija Jezik u (ne)književnim djelima 2014. u Rijeci, Prvi međunarodni znanstveni skup Prevođenje i višejezičnost 2015. u Puli, Međunarodni znanstveni skup Nacionalna i univerzalna kultura u Srednjoj Europi: torelancija, koegzistencija, konflikt 2015. u Slavonskom Brodu, Međunarodna znanstvena konferencija Stoljeće „Priča iz davnine“ Ivane Brlić-Mažuranić 2016. u Zagrebu). Znanstvena su joj istraživanja usmjerena na hrvatski jezik u okviru nekoliko lingvističkih disciplina: fonologiju, leksikologiju s posebnim naglaskom na sinonimiju, homonimiju, polisemiju te međujezične dodire i jezično posuđivanje. Objavila je više radova različite tematike.

Članica je Udruge povjesničara i baštinika zavičajne starine Slavonije, Baranje i Srijema u Slavonskome Brodu. 


\section{POPIS RADOVA}

1. Barišić, Ana Tereza (2019). Naglasni sustav jezika šokačkih pismica, Bosanskohercegovački slavistički kongres II: Zbornik radova sa znanstvenoga skupa s međunarodnim sudjelovanjem održanoga u Sarajevu od 28. do 30. svibnja 2015. (knjiga 1) [ur. Senahid Halilović, Mehmed Kardaš i Emira Mešanović-Meša], Sarajevo: Slavistički komitet, 411-422.

2. Barišić, Ana Tereza (2018). Odgojni aspekti Priča iz davnine - putokaz k trajnim vrijednostima, Stoljeće Priča iz davnine: Zbornik radova s međunarodne znanstvene konferencije Stoljeće „Priča iz davnine“ Ivane Brlić-Mažuranić održane u Zagrebu od 12. do 15. listopada 2016. [ur. Andrijana Kos-Lajtman, Sanja Lovrić Kralj, Nada Kujundžić], Zagreb: Hrvatska udruga istraživača dječje književnosti, 395-408.

3. Barišić, Ana Tereza (2016). Utjecaj posuđenica na jezik pismica Slavonije, Baranje i Srijema, Šesti hrvatski slavistički kongres: Zbornik radova sa znanstvenoga skupa s međunarodnim sudjelovanjem održanoga u Vukovaru i Vinkovcima od 10. do 13. rujna 2014. [ur. Stipe Botica, Davor Nikolić, Josipa Tomašić i Ivana Vidović-Bolt], Zagreb: Hrvatsko filološko društvo - Hrvatski slavistički odbor, 89-100.

4. Barišić, Ana Tereza (2016). Hrvatsko-engleski jezik ili hrvatski jezik?, Studi filologici e interculturali tra traduzione e plurilinguismo, [ur. Rita Scotti Jurić, Nada Poropat Jeletić, Isabella Matticchio], Ariccia (RM): Aracne editrice, 547-558.

5. Barišić, Ana Tereza (2016). Književni prikaz Prvoga svjetskoga rata u kontekstu bećaraca, Pannoniana: Časopis za humanističke znanosti, god. 1., br. 1, 117-134.

6. Barišić, Ana Tereza i Makaj, Zorana (2015). Bećarac - izgubljen u prijevodu, Word across cultures: Zbornik radova s Pete konferencije Instituta za strane jezike ICIFL5 i Društva za primijenjenu lingvistiku Crne Gore održane u Podgorici od 12 do 13. lipnja 2014. [ur. Vesna Bratić i Milica Vuković], Podgorica: Institut za srane jezike, 153-162.

7. Barišić, Ana Tereza (2014). Prikaz antroponimske građe u Gramatici hrvatskoga jezika Josipa Silića i Ive Pranjkovića, Jezik u (ne)književnim djelima: Zbornik radova $\mathrm{s}$ međunarodne studentske konferencije održane u Rijeci od 24. do 25. listopada 2014. [ur. Josip Jagodar], Slavonski Brod: Udruga studenata kroatistike, 103-111. 